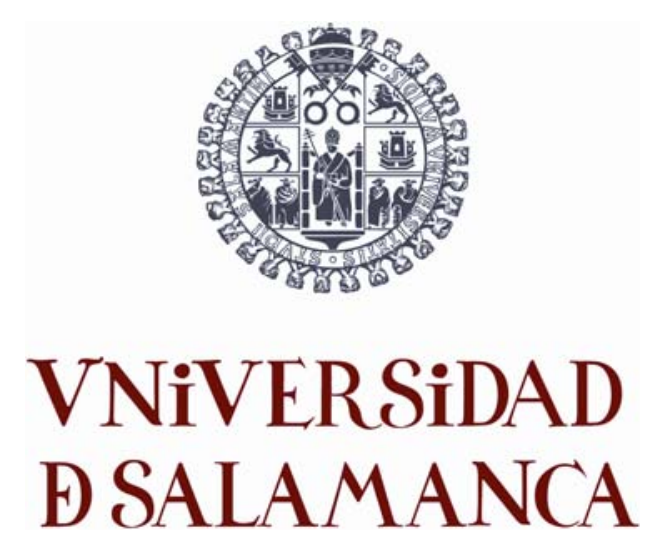

Cultura Científico-Tecnológica y Grupos Minoritarios. El caso de las Personas con Discapacidad

TESIS DOCTORAL

Miguel Ángel Quintanilla Fisac Director

Arlyn Orellana McBride

Departamento de Filosofía y Lógica y

Filosofía de la Ciencia 

Lo importante es no dejar de hacerse preguntas. Albert Einstein 

A mis padres, por su cariño, apoyo y oraciones. 



\section{Agradecimientos}

En estas líneas quiero intentar mostrar mi gratitud a todos aquellos que a lo largo de estos años me han ayudado a desarrollar la investigación y a seguir adelante a pesar de las dificultades.

Aprender de quienes saben más que uno ha sido, desde la antigüedad, una forma de avanzar en el conocimiento. Pero además, en este proceso cognitivo de la humanidad, es imprescindible la innovación, ya sea a través del aporte personal de los individuos o el de los grupos. Y así avanzamos, hacemos crecer el conocimiento de nosotros mismos. La Beca del Banco Santander y la Universidad de Salamanca me ha brindado la oportunidad de participar en ese proceso de enriquecimiento, en lo personal y profesional, mediante el apoyo económico en las convocatorias concedidas.

El Instituto eCyT, y en especial su directora Ana Cuevas Badallo, me ha permitido aprovechar al máximo las posibilidades que brinda la Universidad para la realización de mi investigación. Agradezco a Pilar López Morales su eficiente y siempre oportuna ayuda, a Rosa Fernández López el apoyo en momentos de dudas y a Margarita Ochoa Henao la amistad sincera que me ha brindado cada día. Los consejos y críticas de Antonio Montero Becerra merecen mi más franco reconocimiento, agradezco que haya compartido generosamente conmigo su experiencia como investigador; su criterio y sentido común han sido fundamentales a lo largo de estos años.

A mi director de tesis, Miguel Ángel Quintanilla Fisac, quisiera agradecerle la experiencia ganada en la investigación al colaborar con el proyecto Novatores y la confianza depositada al aceptar trabajar conmigo en la presente tesis. Asimismo, agradezco la disponibilidad que siempre 
ha tenido para conmigo, al igual que el hecho de haberme considerado una de sus prioridades, a pesar de sus muchas responsabilidades políticas.

A Modesto Escobar le agradezco el haberme ayudado, con paciencia y sentido del humor, a salir de los embrollos estadísticos ocasionados por mi propia ignorancia.

Gracias Javi, Eva, José Luis, Refka, David, Mayca, y toda la familia Vargas por acogerme entre ustedes, por hacerme ver que tengo en Salamanca una hermosa familia que siempre ha estado junto a mí.

A mis amigas, Virginia Lira y Macarena Pellegrini, gracias por mantenerse firmes al pie del cañón a pesar de la distancia y los difíciles trances que han experimentado.

A mis padres, hermanos y a toda mi familia, simplemente gracias por quererme tanto y confiar en mí. Agradezco a Dios su cuidado.

Salamanca, diciembre de 2007. 


\section{PARTE I}

La discapacidad en el punto de mira de la cultura

científico-tecnológica

Capítulo 1. Un modelo para la cultura científico-tecnológica...............25

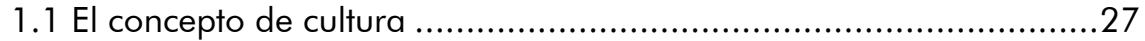

1.1.1 Evolución del concepto. Diferentes autores. ......................27

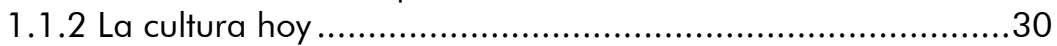

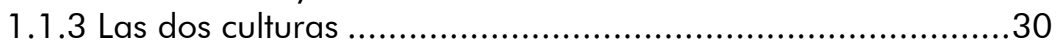

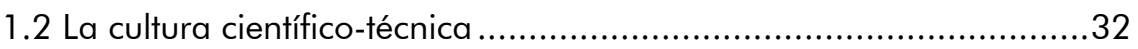

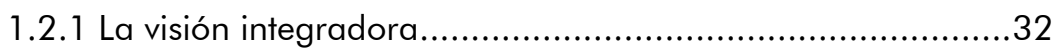

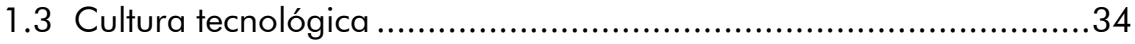

1.3.1 Cultura Incorporada y No Incorporada ...........................35

Capítulo 2. La discapacidad en España. Estado de la cuestión ..............4 4

2.1 Marco legal ................................................................44

2.1.1 Ley de Igualdad de Oportunidades ..............................44

2.1.2 Plan Nacional de I+D+I 2004-2007 .............................47

2.1.3 Ley de Dependencia...............................................50

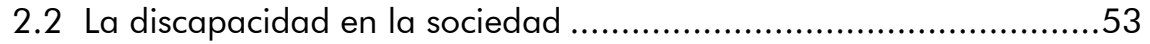

2.3 Discapacidad y ciencia y tecnología ......................................57

2.3.1 Tecnologías de Apoyo a la discapacidad...........................58

2.3.2 El sector tecnológico de las Tecnologías de Rehabilitación

(TR)

2.3.2.1 Agentes sociales y económicos implicados en las TR ........63

2.4 Producción científica española referida a las personas con discapacidad y la tecnología.

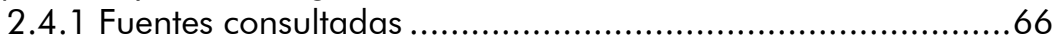

2.4.2 Clasificación de la información....................................74

2.4.3 Análisis de los resultados..............................................78

2.4.3.1 Evolución en el tiempo .........................................78

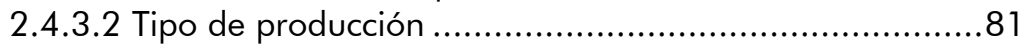

2.4.3.3 Temas ........................................................... 85

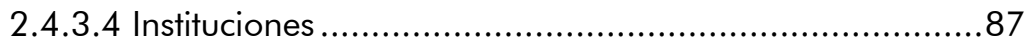

Capítulo 3. Conclusiones..........................................................95 


\section{PARTE II}

Aplicación de un modelo de cultura científico-tecnológica en las personas con discapacidad.

Capítulo 4. El Análisis de contenido: una herramienta científica de investigación

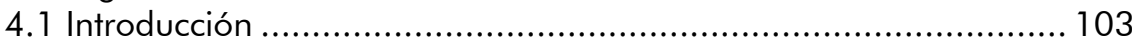

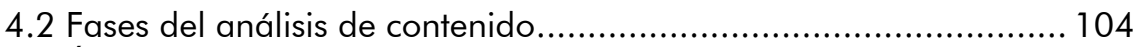

4.3 Árbol temático de las categorías de los análisis de contenido........ 106

4.3.1 Categorías comunes para el análisis de la revista Minusval y los periódicos

4.3.2 Categorías específicas para el análisis de los diarios

(El País y El Mundo) 109

Capítulo 5. Análisis de la revista Minusval................................... 111

5.1 La Revista Minusval .............................................................. 113

5.2 Objetivos del análisis ....................................................... 114

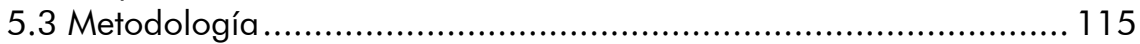

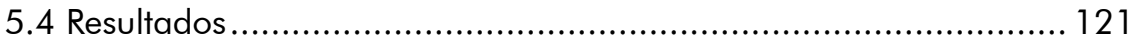

5.4.1 La cultura científico-tecnológica..................................... 121

5.4.1.1 Cultura científica ............................................... 122

5.4.1.2 Cultura tecnológica ........................................... 128

5.4.1.3 Cultura incorporada y no incorporada (intrínseca v/s extrínseca) ................................................................ 132

5.4.1.4 Tipos de información ............................................ 135

5.4.1.4.1 Información Representacional .......................... 136

5.4.1.4.2 Información Práctica ......................................... 138

5.4.1.4.3 Información Valorativa ..................................... 140

5.4.1.5 Relaciones....................................................... 142

5.4.1.5.1 Relación de la Cultura Tecnológica

Intrínseca - Extrínseca .......................................................... 142

5.4.1.5.2 Relación entre la práctica y la valoración .............. 146

5.4.1.5.3 Relación entre la práctica y las creencias ............. 147

5.4.1.5.4 Relación entre los valores y las creencias ............. 149

Capítulo 6. Análisis de la revista Minusval. Las imágenes y valores asociados a las tecnologías........................................................ 151

6.1 Presencia de imágenes y valores en relación a la tecnología......... 154

6.1.1 Positivos ................................................................. 154

6.1.2 Negativos...................................................... 170

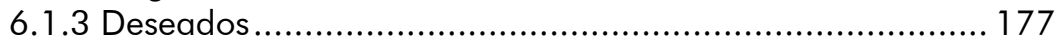

6.2 Aparatos tecnológicos y técnicas.............................................. 183

6.3 Relación entre diferentes tecnologías con las imágenes y

valores asociados a ellas......................................................... 184

6.3.1 Grupo Informática............................................... 184

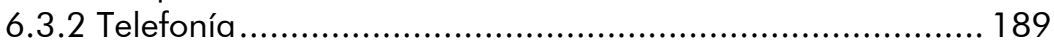

6.3.2 Telefonía .............................................................. 190 
Capítulo 7. Análisis de textos periodísticos. El País y El Mundo 2002-2005

7.1 El País y El Mundo. Noticias de ciencia y tecnología .......................203

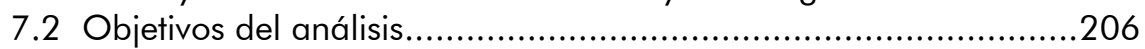

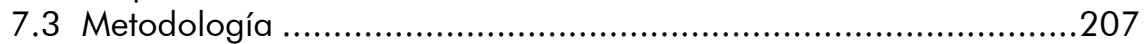

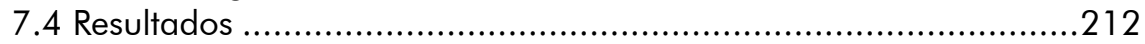

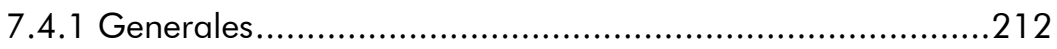

7.4.1.1 El Peso de la cultura científico-tecnológica en la prensa.

7.4.1.2 El Peso de la discapacidad dentro de la cultura científico-tecnológica en la prensa

7.4.2 Presencia de la discapacidad en las noticias de ciencia y tecnología

7.4.3 Cultura científico-tecnológica y PcD

7.4.4 Relación de las PcD con la tecnología

7.4.5 Valores e imágenes asociadas a las tecnologías en relación a las $\mathrm{PcD}$

Capítulo 8. Conclusiones.

CONCLUSIONES GENERALES

UNA MIRADA GLOBAL.

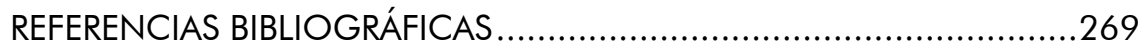

ANEXOS

ANEXO 1

EJEMPLOS DE LA REVISTA MINUSVAL

CLASIFICACIÓN POR CULTURA CIENTÍFICA Y TECNOLÓGICA

ANEXO 2

EJEMPLOS REVISTA MINUSVAL

IMÁGENES Y VALORES

ANEXO 3

EJEMPLOS SIGNIFICATIVOS

EN LA PRENSA (EL PAÍS Y EL MUNDO 2002-2005)

ÍNDICE DE TABLAS Y FIGURAS

TABLAS 



\section{Introducción}

La ciencia y la tecnología están presentes en la vida de cada persona sin importar su nacionalidad, edad, creencias 0 , incluso, sin importar el grado de concienciación que de ello tenga. Han adquirido gran importancia en la economía, las administraciones públicas, las comunicaciones y las experiencias personales; generalmente son entendidas como esenciales para el desarrollo de la humanidad y como herramientas que permiten vivir más y mejor.

Los nuevos conocimientos surgidos de la ciencia sirven, en muchas ocasiones, para disminuir las diferencias de oportunidades que actualmente existen en el mundo. Sin embargo, el conocimiento científico sigue provocando muchos miedos, incertidumbres y dilemas morales y sociales.

Los estudios de percepción pública de la ciencia han demostrado que no existe un rechazo hacia la ciencia y la tecnología, por el contrario, hay encuestas que demuestran que los valores positivos superan a los negativos a la hora de asociarlos con la ciencia y la tecnología, y que la demanda de información en esta área es creciente por parte de la ciudadanía (FECYT 2005, 2007).

A pesar de todo, la cultura científica de la sociedad es todavía deficiente. Muchos autores sostienen que es necesario continuar con los esfuerzos de acercar el conocimiento científico al público lego. Sin embargo, esta tarea se ve entorpecida por la complejidad de ese "público en general". Existe variedad de culturas, lenguas, problemas e intereses, aún dentro de un mismo país que hacen que el mensaje no llegue de manera efectiva a todos por igual. Como Lisbeth Fog señala:

"Exige pensar en grupos específicos que deben ser estudiados de forma independiente para determinar su 
nivel de conocimiento, sus conductas, actitudes y necesidades, y poder así actuar en consecuencia. El 'público' no ha sido estudiado suficientemente por los emisores, y por consiguiente las actividades, muchas veces, no son realmente efectivas. Este es uno de los inmensos vacíos que presentan en el proceso de comunicación de la ciencia" (Fog 2004:37).

El público de la ciencia sigue siendo escaso y se deja de lado a grupos minoritarios como las personas con discapacidad'. Dentro de una sociedad democrática es fundamental que todos sus ciudadanos, sin discriminación alguna, puedan participar con igualdad de oportunidades en la toma de decisiones. En lo que atañe a la ciencia y la tecnología esto adquiere mayor importancia ya que las decisiones en este ámbito son parte esencial de los elementos que configuran el modelo de desarrollo de una sociedad. Estudiar los conocimientos, conductas, actitudes y necesidades de las PcD es tan sólo el primer paso para que, luego de tener las herramientas necesarias para decidir en libertad, los discapacitados se involucren con plenitud en el sistema científicotecnológico.

Estudios anteriores se han centrado en el análisis de los discapacitados como usuarios de determinadas tecnologías ${ }^{2}$. En esta investigación, no sólo se analiza a las personas con discapacidad como las receptoras o usuarias de las acciones y de la información que emanan de la ciencia y la tecnología, sino que también se busca conocer sus creencias, actos y prioridades, (representaciones, prácticas y valores) en relación a la cultura científico-tecnológica. A través de una serie de análisis se conforma una

\footnotetext{
1 Somos conscientes de las discusiones que desde hace mucho rodean la denominación de este colectivo dentro de la sociedad. Últimamente se ha comenzado a llamar "diversamente hábiles" a quienes se designaba como deficientes o minusválidos (términos, en la actualidad, rechazados con amplio consenso por sus connotaciones despectivas) y posteriormente como discapacitados, o desde otra sutil perspectiva, personas con discapacidad. En esta investigación utilizamos estos últimos términos por una razón pragmática al ser conceptos de uso generalizado aún en la sociedad.

${ }^{2}$ Un ejemplo es el Estudio sobre el Impacto de las Nuevas Tecnologías en las Personas con Discapacidad, Universidad de Valencia, IMSERSO, CEAPAT, Diciembre 2000.
} 
visión más clara de las características e intereses de este colectivo referidos a la cultura científica.

Es así como los objetivos generales del presente estudio se sintetizan en los siguientes puntos:

- Conocer el estado de la producción científica española referida a las tecnologías vinculadas a la discapacidad.

- Aplicar un modelo teórico de cultura científica y tecnológica a un grupo específico - personas con discapacidad - mediante dos tipos de análisis (bibliométrico y de contenido).

- Enriquecer, a la luz de los datos obtenidos, el modelo teórico de cultura científico-tecnológica aplicado en la investigación.

Esta investigación realiza un estudio empírico basado en el modelo teórico de cultura científica y tecnológica desarrollado por Miguel Ángel Quintanilla (Quintanilla 2002, 2005) según una especialización temática, al aplicar este modelo en el colectivo de personas con discapacidad. Se estudia el conjunto de rasgos culturales - representacionales, prácticos y valorativos - de las personas con discapacidad en relación a la ciencia y la tecnología.

La metodología de este trabajo se centra en dos análisis fundamentales:

1. Análisis de la oferta y difusión de ciencia y tecnología hacia las personas con discapacidad ( $P C D)$ a través de dos líneas: 


\subsection{Información generada sobre tecnologías y discapacidad}

- Mediante un análisis bibliométrico se ha contabilizado la producción científica española de investigaciones y productos tecnológicos relacionados con las PcD. Los datos se han obtenidos de las bases de datos de la ISI Web of Knowledge, bases de datos del CSIC, CINDOC, ICYT, SCIRUS y mediante un rastreo de las actas de congresos, revistas especializadas no científicas (sus publicaciones no siguen controles rigurosos, como la revisión por pares).

\subsection{Información transmitida sobre ciencia y tecnología:}

- Análisis de contenido de la información científica y tecnológica que reciben las PcD. Los datos para este análisis se han obtenido de una muestra significativa de la revista Minusval, una publicación bimensual de divulgación, dirigida especialmente a personas con discapacidad.

2. Análisis de la imagen en la sociedad de las PcD en su relación con la ciencia y la tecnología:

2.1 Análisis de contenido de una muestra significativa de la información sobre ciencia, tecnología y discapacidad publicada en la prensa española. Los periódicos analizados son El Mundo y El País, en sus ediciones nacionales del período comprendido entre los años 2002 y 2005. Para la selección de la muestra se ha utilizado la técnica de muestreo de la semana construida ${ }^{3}$.

En la realización de los diferentes análisis se han utilizado programas informáticos especialmente diseñados para estas tareas, bases de datos Access para la recopilación de los textos periodísticos, el programa

\footnotetext{
${ }^{3}$ Cfr. p. 207, Capítulo 7.
} 
ATLAS.ti para los análisis de contenido y SPSS para analizar estadísticamente las variables cuantitativas obtenidas de la investigación.

Este trabajo parte de la curiosidad por conocer mejor las relaciones bidireccionales que se generan entre las personas con discapacidad (PcD) y el sistema científico-tecnológico. Dentro del sistema científico-tecnológico están presentes tanto las teorías, descubrimientos, hechos científicos y las prácticas inherentes al método científico, como la invención, desarrollo o difusión de técnicas o aparatos tecnológicos. Un sistema complejo que no sólo presenta relaciones entre sus propios elementos, sino que también genera interacciones con su entorno.

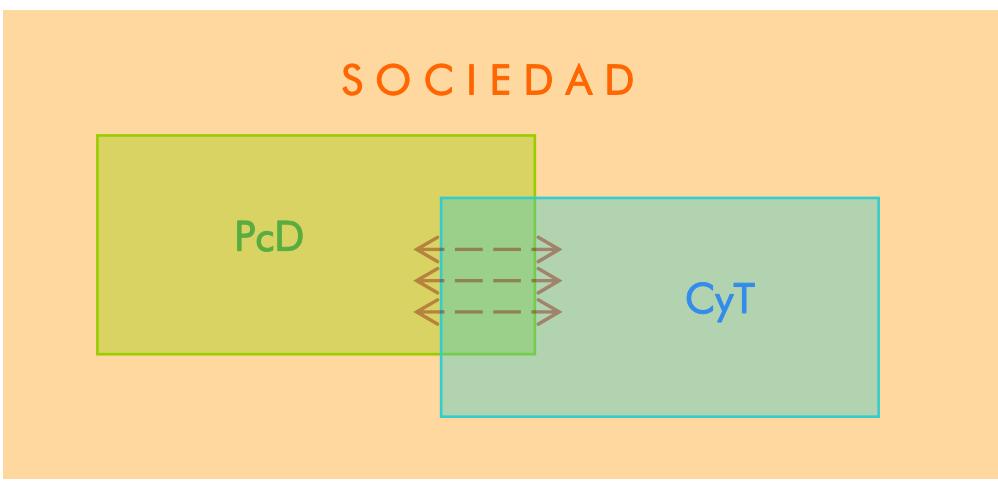

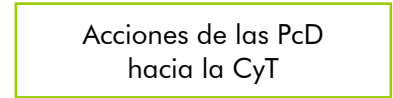

Información representacional, práctica y valorativa que fluye desde las personas con discapacidad hacia la ciencia y tecnología.
Acciones de la CyT hacia las PcD

Información representacional, práctica y valorativa que fluye desde la ciencia y tecnología hacia las personas con discapacidad.

Fig. 0.1 Esquema de la relación entre las PcD y la CyT

Las acciones de las PcD y las de la ciencia y la tecnología (CyT) se influyen mutuamente dentro de un sistema dinámico, en el que hay un continuo intercambio de ideas o creencias (información representacional), normas 
o pautas de comportamiento (información práctica) y juicios de valor o preferencias (información valorativa). La manera en la que se desarrolla este flujo de conocimientos conforma la cultura científico-tecnológica de las personas con discapacidad.

Al comenzar el estudio, partimos de ciertos presupuestos. Por un lado, que las PcD en España son receptores de investigaciones y tecnologías, con escasa presencia activa en el sistema. Por otra parte, que poseen una doble percepción de la ciencia y la tecnología como un elemento integrador y a la vez discriminatorio en la sociedad.

Además, presuponemos que este colectivo tiene una cultura científicotecnológica eminentemente práctica, con información representacional referida a lo que satisfaga sus necesidades y con valores utilitaristas.

A lo largo de este estudio daremos respuesta a estos planteamientos, mediante los análisis señalados.

En la primera parte, "La discapacidad en el punto de mira de la cultura científico-tecnológica", nos introducimos, con el Capítulo 1, en el modelo de cultura científico tecnológica desarrollado por Quintanilla, haciendo un pequeño repaso histórico del concepto de cultura y su relación con la ciencia y la tecnología.

En el Capítulo 2 se recoge la situación de las personas con discapacidad en España, mediante la descripción del marco legal actual, los aspectos sociales y su relación con la ciencia y la tecnología, especialmente a través de las tecnologías de ayuda. Destaca en esta sección el análisis de la producción científica española referida a las personas con discapacidad y la tecnología. 
Finaliza la primera parte con un capítulo de conclusiones parciales de la investigación.

La segunda parte de la tesis, "Aplicación de un modelo de cultura científico-tecnológica en las personas con discapacidad", comienza con el Capítulo 4, en el que se revisan las bases del análisis de contenido en relación a los efectuados en esta investigación.

El Capítulo 5 presenta el análisis de la revista Minusval, una publicación dirigida a personas con discapacidad, profesionales y entidades que trabajan en favor de este colectivo. Se ofrece una visión de la cultura científico tecnológica que llega a las personas con discapacidad por medio de esta revista. Se profundiza en la relación que se observa entre los aparatos tecnológicos y técnicas y los discapacitados, a través de un análisis cualitativo de los valores y conceptos que se difunden en relación a la tecnología.

En el capítulo 6 se desarrolla el análisis de las noticias de ciencia y tecnología, publicadas en los diarios españoles El País y El Mundo durante el periodo comprendido entre el año 2002 y el 2005, ambos inclusive. La exploración de estos textos periodísticos se ha llevado a cabo tomando en cuenta el peso de la presencia del tema de la discapacidad en las noticias, la cantidad y tipo de cultura científica, la relación que se proyecta entre las personas con discapacidad y las tecnologías $y$, finalmente al igual que en la revista Minusval, cuáles son las características y valores asociadas a los aparatos y las técnicas relacionadas con las PcD.

Para concluir la segunda parte se presentan las conclusiones parciales de esta sección de la investigación. 
Cultura Científico-Tecnológica y Grupos Minoritarios. El caso de las Personas con

Discapacidad

El tercer y último apartado de la tesis lo conforman las conclusiones generales, donde con una mirada global se resumen los principales resultados de la investigación y las aplicaciones que ellos aportan al modelo de cultura científico tecnológica aplicado en el presente estudio. 
PARTE I

La discapacidad en el punto de mira de la cultura científico-tecnológica 
Capítulo 1. Un modelo para la cultura científicotecnológica 


\subsection{El concepto de cultura}

1.1.1 Evolución del concepto. Diferentes autores.

Según la vigésima segunda edición del diccionario de la Real Academia Española de la Lengua la palabra "cultura" proviene del latín cultūra, que significa primariamente agricultura. De esta palabra se desprende el adjetivo latino culto, que indica la propiedad del campo de estar cultivado. Su uso original ha ido evolucionando con el tiempo y "de designar algo tan fundamental para la sociedad romana como la agricultura, la palabra cultura había ido evolucionando semánticamente hasta acabar refiriéndose a algo tan superficial como los pasatiempos de la clase ociosa" (Mosterín 1993:17).

El concepto de cultura ha sido analizado, definido y criticado por numerosos expertos en disciplinas como la sociología, la antropología y la filosofía. En 1871 Edward B. Tylor realiza la primera definición de cultura aproximada a la concepción moderna del término al decir que,

"la cultura o civilización, en sentido etnográfico amplio, es aquel todo complejo que incluye el conocimiento, las creencias, el arte, la moral, el derecho, las costumbres y cualesquiera otros hábitos y capacidades adquiridos por el hombre en cuanto miembro de la sociedad" (Tylor 1977:19).

Esta definición reconoce ya las dificultades que existen para identificar y caracterizar a la cultura como objeto de estudio ("todo complejo") y, más importante aún, reconoce la relación entre este conocimiento adquirido, no innato, y la pertenencia a un grupo, la sociedad.

Posteriormente Alfred Kroeber (1975:48) profundiza en la diferenciación de los conocimientos adquiridos por medio del contacto con la sociedad, "nos llegan a través de agentes con los que la herencia (genética) nada 
tiene que ver" y aquellos que "proceden de la naturaleza, a través de la herencia".

En 1931, Bronislaw Malinowski va más allá, haciendo una diferencia entre cultura y civilización, ya que para él civilización denomina un aspecto especial de las culturas más avanzadas. Según Malinowski (1975:91), "la cultura consta de la masa de bienes e instrumentos, así como de las costumbres y de los hábitos corporales o mentales que funcionan directa 0 indirectamente para satisfacer las necesidades humanas."

La cultura sería un aspecto del ser humano que involucra necesariamente lo que él llama "pertrechos materiales", es decir todos aquellos artefactos, construcciones, embarcaciones, instrumentos o armas, "los aspectos más evidentes y tangibles de la cultura". En definitiva, cuando habla de cultura se refiere a "una realidad instrumental que ha aparecido para satisfacer las necesidades del hombre que sobrepasan la adaptación al medio ambiente" (Malinowski 1975:126).

Recuérdese el magistral ensayo "Meditaciones de la técnica" del filósofo español Ortega y Gasset:

"De donde resulta que estos actos [técnicos] modifican o reforman las circunstancia o naturaleza, logrando que en ella haya lo que no hay sea que no lo hay aquí y ahora cuando se necesita, sea que en absoluto no lo hay. Pues bien: estos son los actos técnicos, específicos del hombre. El conjunto de ellos es la técnica, que podemos, desde luego, definir como la reforma que el hombre impone a la naturaleza en vista de la satisfacción de sus necesidades. Estas, hemos visto, eran imposiciones de la naturaleza al hombre. El hombre responde imponiendo a su vez un cambio a la naturaleza. Es, pues, la técnica, la reacción enérgica contra la naturaleza o circunstancia, que lleva a crear entre éstas y el hombre una nueva naturaleza puesta sobre aquélla, una sobrenaturaleza". (Ortega y Gasset 1998:28) 
En esta misma línea, Emilio Lamo de Espinosa señala que "la cultura es así, literalmente, como una segunda naturaleza que suple la 'deficiencia' o plasticidad de la primera, que nos dotó de pocos instintos para que pudiéramos aprender mucho" (Lamo de Espinosa 1996:28). Según este autor, la cultura es un conjunto de conocimientos, pero también es la capacidad de crear, acumular y transmitir tales conocimientos.

Jesús Mosterín en su libro Filosofía de la Cultura adopta la siguiente definición de cultura: "cultura es la información transmitida (entre animales de la misma especie) por aprendizaje social" (Mosterín 1993:32). Esta información adquirida a través de la interacción dentro de una sociedad puede ser de tres tipos: descriptiva, práctica o valorativa. La información descriptiva es información teórica, datos, el "saber qué"; la práctica o técnica, se refiere a las instrucciones, las habilidades, el knowhow; finalmente, la información valorativa o evaluativa abarca las preferencias, valores, metas y actitudes.

Mosterín diferencia, tal como lo hacía Kroeber, entre los conocimientos que posee el ser humano por el hecho de pertenecer a la especie humana, esto es, aquellos conocimientos que le han sido transmitidos por herencia genética, y los conocimientos apropiados mediante un proceso de aprendizaje.

"Todo lo que el organismo sabe hacer (en un sentido amplísimo, es decir, es capaz de hacer) porque está genéticamente preprogramado para hacerlo forma parte de su natura. Todo lo que el organismo sabe hacer, porque ha aprendido socialmente a hacerlo, constituye su cultura. Hablando de seres vivos, natura es información transmitida genéticamente; cultura es información transmitida no genéticamente, sino por aprendizaje social." (Mosterín 1993:20) 


\subsubsection{La cultura hoy}

A pesar de la evolución del concepto en las diferentes disciplinas, la palabra cultura continúa siendo un término al que se le otorga un significado asociado exclusivamente a las expresiones artísticas como la literatura, la música, el teatro o el cine. Por ejemplo, algunas de las áreas de actividad del Ministerio de Cultura de España son Artes Escénicas y Música, Bibliotecas, Cine y Audiovisuales, Patrimonio Histórico y Promoción del Arte.

En los ayuntamientos se denominan "actividades culturales" a las exposiciones de pintura, al teatro, a los ciclos de cine, a los conciertos de diferentes tipos de música, a la danza. En resumen, se continúa utilizando el concepto de cultura para referirse a aquellas actividades artísticas consideradas como elevadas, de una especie de categoría superior.

\subsubsection{Las dos culturas}

El conocimiento humano ha sido clasificado y dividido en diferentes categorías a lo largo de la historia. Una de las más famosas divisiones es la planteada por C.P. Snow en 1959, en la conferencia The Rede Lecture, donde señalaba la existencia de dos grupos polarizados. A un lado ponía a los intelectuales de humanidades ("literary intellectuals") y al otro extremo a los científicos, especialmente a los físicos ("physical scientists"). Entre ellos denunciaba la existencia de una sima de mutua incomprensión y hostilidad, que llevaba por ejemplo, a los humanistas a pensar de los científicos como personas temerarias y presumidas, y a los científicos de los humanistas como arrogantes e ignorantes.

Esta separación entre las humanidades y las ciencias ha sido asumida tanto por unos como por otros y no sólo asumida, sino también defendida 
en una especie de batalla ideológica para determinar la importancia y la utilidad de cada disciplina en la sociedad.

Aún ahora, a pesar de que se busca superar esta brecha, continúa existiendo la sensación de que se pertenece a distintos bandos entre los que hay diferencias irreconciliables. Ser "de letras" es excusa para desconocer cualquier aspecto relativamente complejo de las matemáticas o anatomía humana. Por otra parte, "ser de ciencias" parece ser que otorga la licencia para no saber ortografía o literatura.

Según Sánchez Ron, "hermanar, vincular íntimamente humanidades y ciencias 'asociales' es una tarea, si no imposible, sí sumamente difícil" (Sánchez Ron 1995:46). Para que esto suceda, para que se supere la brecha de estas dos culturas, Sánchez Ron propone

"... establecer una nueva cultura, en la que la dimensión antropológica no se vea marginada por la cognoscitiva (entendida ésta como una mera asimilación de conocimientos); una cultura en la que la ciencia se acerque a las humanidades no tanto por la simplificación (divulgación) del aparato técnico que contienen, como por aproximarse más al mundo de los intereses inicialmente primitivos, hoy esencialmente actuales, de los seres humanos. A esta nueva cultura la denominaré "tercera cultura" (Sánchez Ron 1995:46). 


\subsection{La cultura científico-técnica}

La demarcación de una frontera entre humanidades y ciencia ha llevado a la utilización exclusiva del término "cultura" para aquellos conocimientos y actividades humanas pertenecientes al ámbito de la literatura y las artes. Pero la visión de la ciencia alejada de la cultura, como planteaba Snow, es sólo una de las representaciones que se han planteado de las relaciones que existen entre la ciencia, la tecnología y la cultura.

Con la aparición de comunicadores o divulgadores de la ciencia se pasó a la perspectiva de la ciencia como una institución que transmite o difunde sus conocimientos hacia la sociedad. Desde este punto de vista, la cultura científica estaría conformada por los conocimientos que poseerían los propios científicos y que se deberían transmitir al público profano (Lévy-Leblond 2003).

Sin embargo, este segundo modelo de relación entre Ciencia y Cultura no considera a los científicos y a las instituciones científicas como una parte de la cultura. Encontramos, sin embargo, un tercer modelo en el que la ciencia y la tecnología vienen definidas desde el principio como parte de la organización social (Godin 2000).

\subsubsection{La visión integradora}

Si consideramos la definición de Mosterín (1993:32) de cultura ("información que es transmitida por aprendizaje social") tenemos, pues, que dependiendo del contenido de esa información - ya sean creencias, ideas, valores, reglas o pautas de comportamiento- la cultura de un grupo puede ser ordenada por diversas temáticas. Así se habla de cultura 
literaria, musical, pictórica, religiosa, política, deportiva, empresarial, científica, tecnológica, etc.

Esta información transmitida por aprendizaje social puede clasificarse como de tres tipos: representacional, práctica o valorativa.

Información representacional.

La información cultural transmitida tiene un contenido representacional cuando se refiere a conocimientos, imágenes, símbolos, formas de ver el mundo. En definitiva, es información acerca de las características y propiedades del grupo social y su entorno.

Información práctica.

La información cultural transmitida tiene un contenido práctico cuando se refiere a normas $o$ reglas $y$ formas de comportamiento características de un grupo. Pueden ser normas o reglas de actuación consideradas como dignas de ser cumplidas y pautas efectivas 0 hábitos de comportamiento observadas en la práctica del grupo. La información práctica señala el cómo hay que actuar.

Información valorativa.

La información cultural transmitida tiene un contenido valorativo cuando se refiere a un conjunto de objetivos, preferencias o actitudes, fines de actuación y valores. Entrega información acerca de qué estados de cosas son preferibles, convenientes o valiosos. 


\subsection{Cultura tecnológica}

En el proceso de configuración de la cultura de una sociedad, las técnicas han jugado un importante papel, su invención e implantación dependen del ámbito cultural en el que surjan y, una vez extendidas, influyen en los cambios culturales de esa sociedad. Esta idea fue recogida ya en la década de los 30 por Ortega y Gasset:

\footnotetext{
"El pueblo en que predomina la idea de que el verdadero ser del hombre es ser bodhisatva no puede crear una técnica igual a aquel otro en que se aspira a ser un gentleman. Ser bodhisatva es, por lo tanto, creer que existir en este mundo de meras apariencias es precisamente no existir de verdad. (...) No es verosímil que invente el automóvil este hombre que no quiere moverse. En cambio, suscitará todas esas técnicas tan ajenas a nosotros europeos como son las de los faquires y yoghis." (Ortega y Gasset 1998:58)
}

A lo largo de la historia, filósofos, historiadores y sociólogos se han referido tanto a la técnica como a la tecnología al referirse indistintamente a los artefactos producidos mediante una técnica o tecnología, como a los procesos o sistemas de acciones que dan como resultado tales artefactos. Además, han sido empleadas para designar conocimientos sistematizados (tecnología) o no sistematizados (técnicas artesanales, por ejemplo).

En este estudio utilizaremos, al igual que Quintanilla (2005), el término tecnología para referirnos a las técnicas industriales de base científica, ya que la tecnología actual tiene una fuerte relación con el conocimiento científico. Por una parte depende del desarrollo de la ciencia y, por otra, el desarrollo tecnológico condiciona el avance del conocimiento científico. 
A la hora de analizar las interacciones entre la tecnología y la cultura, los sistemas técnicos permiten estudiar estas relaciones tomando en cuenta elementos sociales, organizativos, culturales, cognitivos y económicos. Un sistema técnico es una "unidad compleja formada por artefactos, materiales y energía, para cuya transformación se utilizan los artefactos, y agentes intencionales (usuarios $u$ operarios) que realizan esas acciones de transformación" (Quintanilla 1998a: 51).

Cultura técnica es, entonces, un conjunto de conocimientos (principalmente prácticos) de los que dispone un determinado grupo social cuyos rasgos culturales (representaciones, reglas y valores) están relacionados con la técnica.

\begin{tabular}{ll}
\hline Representacional & $\begin{array}{l}\text { Son los conocimientos, creencias y } \\
\text { representaciones conceptuales o } \\
\text { simbólicas sobre las técnicas y sobre los } \\
\text { sistemas técnicos. }\end{array}$ \\
\hline Operacional (Práctico) & Son las reglas y pautas de \\
& comportamiento, habilidades y \\
& conocimientos operacionales - prácticos \\
& - referidos a sistemas técnicos. \\
\hline Valorativa & Son todos aquellos objetivos, valores y \\
& preferencias relativos al diseño, \\
& adquisición, uso, etc., de sistemas \\
& técnicos y de conocimientos técnicos. \\
\hline
\end{tabular}

Tabla 1.1 Componentes de la Cultura Técnica

Fuente: M.A. Quintanilla (2002:24)

\subsubsection{Cultura Incorporada y No Incorporada}

Como veíamos, uno de los componentes de un sistema técnico son agentes humanos que requieren información de su propia cultura para actuar dentro del sistema. Esta información, consistente en conocimientos representacionales, operativos y valorativos, puede presentarse en dos 
modalidades: contenidos incorporados o no incorporados al sistema técnico.

\begin{tabular}{|c|c|}
\hline Contenidos Incorporados & Contenidos No Incorporados \\
\hline Información Representacional & Información Representacional \\
\hline $\begin{array}{l}\text { Conocimientos, creencias o } \\
\text { representaciones que poseen } \\
\text { los agentes acerca de los } \\
\text { componentes, estructura y } \\
\text { funcionamiento del sistema. }\end{array}$ & $\begin{array}{l}\text { Representaciones que se refieren } \\
\text { a los sistemas técnicos, que no } \\
\text { forman parte de éstos, pero que } \\
\text { son relevantes para su diseño, } \\
\text { producción y uso. }\end{array}$ \\
\hline
\end{tabular}

\begin{tabular}{lll}
\hline Información Operacional & & Información Operacional \\
\hline Habilidades prácticas y reglas & Reglas de actuación que se \\
de actuación que los agentes & refieren a los sistemas técnicos, \\
son capaces de seguir para & que no forman parte de éstos, \\
operar con el sistema, o para & pero que son relevantes para su \\
diseñarlo y construirlo. & diseño, producción y uso.
\end{tabular}

\begin{tabular}{ll}
\hline Información Valorativa & Información Valorativa \\
\hline Valores referidos & Valoraciones que se refieren a \\
especialmente a los objetivos y & los sistemas técnicos, que no \\
resultados de cada una de las & forman parte de éstos, pero que \\
acciones así como del sistema. & $\begin{array}{l}\text { son relevantes para su diseño, } \\
\text { producción y uso. }\end{array}$ \\
\hline
\end{tabular}

Tabla 1.2 Contenidos Incorporados y No Incorporados Fuente: M.A. Quintanilla (2002:29-30)

En resumen, la cultura técnica de una sociedad en un momento determinado se caracteriza por información representacional, operacional y valorativa incorporada y no incorporada a los sistemas técnicos de que dispone esa sociedad.

Por ejemplo, la imagen que se tenga de la tecnología y su relación con el ser humano es un conocimiento extrínseco a los sistemas técnicos - se refiere a ellos sin formar parte de ellos - pero puede afectar a su diseño, producción o uso. 
La tecnología está cambiando la relación hombre-objeto y hombre-máquina. La última década se ha caracterizado, sin duda, por el fuerte desarrollo y la amplia difusión de nuevos materiales, las tecnologías electrónicas y las tecnologías informáticas. La consecuencia de esto ha sido la aparición de una nueva generación de objetos, los llamados "objetos tecnológicos", relacionados con los nuevos medios de comunicación: los ordenadores de bolsillo, Internet, móviles, MP3, notebook. (Minusval, № 133. Marzo - Abril 2002)

En cambio, la descripción de la estructura y características funcionales de un aparato para sordos, por ejemplo, es información representacional intrínseca a la tecnología.

Los audífonos de última generación son casi todo menos un mero amplificador del sonido. En minúsculas carcasas de apenas un centímetro cúbico de volumen es posible encontrar dos micrófonos multidireccionales, un amplificador capaz de alcanzar 140 decibelios, un altavoz y un paquete de por lo menos cuatro chips de silicio que almacenan medio megabit de memoria que da cabida a programas informáticos que se ajustan automáticamente a distintos escenarios acústicos.

El País $\quad 31 / 12 / 2003$

Los nuevos aparatos para sordos son ordenadores minúsculos dentro del oído

En cuanto a la información práctica, hay reglas de actuación, componentes operacionales que deben estar incorporados a los sistemas para su funcionamiento. Por ejemplo, para hacer accesibles las páginas en Internet a las personas con discapacidad existen unas pautas de diseño y creación de sitios web, pautas WAI (Iniciativa para la Accesibilidad de la 
Web) desarrolladas por el Consorcio World Wide Web. Estas normas son intrínsecas al diseño y construcción de páginas web.

Por otra parte, hay prácticas que son extrínsecas a los sistemas técnicos, no forman parte de éstos, pero que les afectan en su producción o uso. Premios a la innovación tecnológica, leyes emitidas desde las administraciones públicas, actuaciones de sociedades empresariales, estudios del mercado de las ayudas técnicas, son ejemplos de información práctica no incorporada a la tecnología.

La información valorativa también puede ser extrínseca o intrínseca a la cultura tecnológica. Por un lado, los objetivos incorporados a los sistemas técnicos como la accesibilidad o la eficiencia son valores intrínsecos a la tecnología.

Los servicios domóticos deben ser accesibles para todos los usuarios, y su utilización debe resultar eficiente y fácil de aprender. (Minusval № 158. Julio - Agosto 2006)

En cambio, valores o preferencias que no tienen que ver intrínsecamente con el sistema, pero que afectan a su uso o desarrollo constituyen información valorativa no incorporada. No afectan a la tecnología en sí las preferencias de color de un determinado iMac de Apple o la consideración de un ordenador como un objeto "amigable" o "coloquial"; en contraposición con las normas de estructura y de maquetación que obliga el valor de accesible de una página web, por ejemplo.

...son muchos los que sólo aceptan las aplicaciones técnicas -ya se trate de ayudas especiales o de productos de consumo corriente- con la condición de que tengan un diseño atractivo y se integren bien en su entorno normal. Los productos y servicios 
deben ser atractivos y deben incitar a los interesados a usarlos. (Minusval, Especial La Discapacidad en Europa. Mayo 2003)

Resumimos en la siguiente tabla los tres tipos de información presentes en la cultura técnica de cualquier grupo social, según sean intrínsecos (incorporados) o extrínsecos (no incorporados) a los sistemas técnicos a los que se refieren.

Cultura Técnica Incorporada Cultura Técnica No Incorporada Información Representacional Información Representacional

Componentes cognitivos, Conocimientos científicos básicos no representacionales o simbólicos: incorporados a los sistemas técnicos, conocimientos técnicos y científicamente aplicados. pero con potenciales aplicaciones técnicas. Representaciones simbólicas de la realidad, especialmente de los sistemas técnicos y sus relaciones con la sociedad, mitos tecnológicos (o antitecnológicos), etc.

\begin{tabular}{|c|c|}
\hline Información Operacional & Información Operacional \\
\hline $\begin{array}{l}\text { Componentes prácticos U } \\
\text { operacionales: reglas de } \\
\text { operación, habilidades técnicas } \\
\text { de diseño, producción y uso de } \\
\text { artefactos. }\end{array}$ & $\begin{array}{l}\text { Reglas de actuación de carácter social, } \\
\text { moral, religioso, político, económico, } \\
\text { etc., significativas para el uso y } \\
\text { desarrollo de sistemas técnicos. }\end{array}$ \\
\hline Información Valorativa & Información Valorativa \\
\hline $\begin{array}{l}\text { Objetivos incorporados a los } \\
\text { sistemas técnicos y valoración de } \\
\text { sus resultados. }\end{array}$ & $\begin{array}{l}\text { Valores y preferencias significativas } \\
\text { para el uso y desarrollo de sistemas } \\
\text { técnicos. }\end{array}$ \\
\hline
\end{tabular}

Tabla 1.3 Cultura Técnica Incorporada y No Incorporada Fuente: M.A. Quintanilla (2002)

Así es como, mediante la clasificación del conocimiento de un determinado grupo social, es posible conocer cómo es su cultura 
científico-tecnológica. Podemos averiguar la proporción de información representacional, práctica o valorativa que conforma su conocimiento, en este caso, de la ciencia y la técnica; si esta información es mayoritariamente intrínseca o extrínseca; y descubrir cuáles son los valores que priman ante el uso o desarrollo de ciertas tecnologías.

En definitiva, mediante la aplicación de este esquema se puede representar cuantitativa y cualitativamente la cultura científico-tecnológica de una sociedad; una representación que, sin dejar de ser un reflejo de la realidad nos permitirá caracterizar y conocer con mayor profundidad la complejidad del público de la ciencia y la tecnología, facilitando así la tarea de la divulgación de la cultura científica y llenado un vacío en la comunicación pública de la ciencia. 
Capítulo 2. La discapacidad en España. Estado de la cuestión 


\subsection{Marco legal}

Para conocer la situación de las personas con discapacidad en España y su relación con la ciencia y la tecnología comenzaremos por analizar la legislación vigente. La revisión de las normativas nos proporciona información objetiva de las herramientas y oportunidades potenciales con las que cuenta este grupo en la sociedad.

Según el Servicio de Información sobre Discapacidad de la Universidad de Salamanca (SID) ${ }^{4}$ en 2006 había un total de 1.420 documentos legislativos en España que hacían referencia a la discapacidad (Ver Tabla 2.1). De todos estos documentos revisaremos la "Ley de igualdad de oportunidades, no discriminación y accesibilidad universal de las personas con discapacidad"; el Plan Nacional de Investigación Científica, Desarrollo e Innovación Tecnológica 2004-2007 y la "Ley de Promoción de la Autonomía Personal y Atención a las personas en situación de dependencia".

\footnotetext{
${ }^{4}$ http://sid.usal.es/
} 
Documentos legislativos en España que hacen referencia a la discapacidad:

- Leyes Ordinarias (16 referencias)

- Decretos-Leyes (1 referencia)

- Decretos Legislativos (3 referencias)

- Decretos (42 referencias)

- Órdenes Ministeriales (75 referencias)

- Resoluciones (240 referencias)

- Otras Disposiciones del Estado (19 referencias)

- Leyes Autonómicas (48 referencias)

- Decretos Autonómicos (150 referencias)

- Órdenes Autonómicas (378 referencias)

- Resoluciones Autonómicas (231 referencias)

- Otras Disposiciones Autonómicas (146 referencias)

- Reglamentos (1 referencia)

- Directivas (3 referencias)

- Decisiones (2 referencias)

- Resoluciones (14 referencias)

- Recomendaciones (2 referencias)

- Dictámenes (2 referencias)

- Otras disposiciones UE (20 referencias)

- Acuerdos y Recomendaciones (1 referencia)

- Resoluciones de Organismos Internacionales (4 referencias)

- Sentencias y Jurisprudencia (8 referencias)

- Otras Disposiciones (14 referencias)

Tabla 2.1 Documentos legislativos relacionados con la discapacidad

Fuente: Servicio de Información sobre Discapacidad de la Universidad de Salamanca (SID) http://sid.usal.es

\subsubsection{Ley de Igualdad de Oportunidades}

Dentro del marco legislativo, las normativas que se centraban en el año 2006 de un modo general en la situación de las personas con discapacidad, eran la Ley 13/1982 de 7 de Abril, de Integración Social de los Minusválidos (LISMI) y la Ley 51/2003, de 2 de diciembre, de igualdad de oportunidades, no discriminación y accesibilidad universal de las personas con discapacidad; ambas leyes, complementarias en sus alcances y efectos.

La última, publicada en el BOE el 3 de diciembre de 2003, señala que en España hay alrededor de 3,5 millones de personas con alguna 
discapacidad. Es decir, aproximadamente un $8 \%$ de la población tienen alguna limitación grave, con origen en alguna deficiencia (cualquier pérdida o anomalía de un órgano o de la función propia de un órgano) que afecta o se espera que afecte durante más de un año a la actividad del que la padece.

Se considera que una persona tiene una discapacidad aunque la tenga superada con el uso de ayudas técnicas externas (INE 1999). Para efectos de esta ley, una persona con discapacidad es aquella a quien se les reconoce un grado de minusvalía igual o superior al 33\% (Cap. I, Art. 1).

Se reconoce como necesidad de las personas con discapacidad el precisar "garantías suplementarias para vivir con plenitud de derechos o para participar en igualdad de condiciones que el resto de los ciudadanos en la vida económica, social y cultural del país" (BOE núm. 289 de 2003:43187). Expresa, además, en la exposición de motivos que

"hoy es sabido que las desventajas que presenta una persona con discapacidad tienen su origen en sus dificultades personales, pero también y sobre todo en los obstáculos y condiciones limitativas que en la propia sociedad, concebida con arreglo al patrón de la persona media, se oponen a la plena participación de estos ciudadanos" (BOE núm. 289 de 2003:43187). 
La Ley 51/2003 se refiere a los discapacitados como

\begin{abstract}
"personas que tienen especiales dificultades para satisfacer unas necesidades que son normales, más que personas especiales con necesidades diferentes al resto de sus conciudadanos y como ciudadanos que para atender esas necesidades demandan apoyos personales, pero también modificaciones en los entornos que erradiquen aquellos obstáculos que les impiden su plena participación" (BOE núm. 289 de 2003: 43188).
\end{abstract}

Los ámbitos de aplicación de esta ley son:
a) Telecomunicaciones y sociedad de la información,
b) Espacios públicos urbanizados, infraestructuras y edificación,
C) Transportes,
d) Bienes y servicios a disposición del público,
e) Relaciones con las Administraciones públicas.

Por otro lado, la ley condena abiertamente la discriminación hacia las personas con discapacidad en el Capítulo II, artículo que señala:

\footnotetext{
"Se entenderá que se vulnera el derecho a la igualdad de oportunidades de las personas con discapacidad cuando se produzcan discriminaciones directas $\circ$ indirectas, acosos, incumplimientos de las exigencias de accesibilidad y de realizar ajustes razonables, así como el incumplimiento de las medidas de acción positiva legalmente establecidas" (BOE núm. 289 de 2003: 43189).
}

Estas medidas de acción positiva, que salvaguardan el derecho a la igualdad de oportunidades de este colectivo, son definidas por la ley como los 
"apoyos de carácter específico destinados a prevenir o compensar las desventajas $\circ$ especiales dificultades que tienen las personas con discapacidad en la incorporación y participación plena en los ámbitos de la vida política, económica, cultural y social, atendiendo a los diferentes tipos y grados de discapacidad" (BOE núm. 289 de 2003: 43190).

En el campo de la ciencia y la tecnología destacan las tecnologías de apoyo, que son consideradas como fundamentales para la accesibilidad y no discriminación (Cap. II, Art.10.). Además, esta ley en su capítulo III, contempla medidas de fomento del desarrollo tecnológico. El Artículo 14 expresa:

"1. Las Administraciones públicas fomentarán la innovación en todos los aspectos relacionados con la calidad de vida de las personas con discapacidad. Para ello, promoverán la investigación en las áreas relacionadas con la discapacidad en los planes de investigación, desarrollo e innovación (I+D+I).

2. Asimismo, facilitarán y apoyarán el desarrollo de normativa técnica, así como la revisión de la existente, de forma que asegure la no discriminación en procesos, diseños y desarrollos de tecnologías, productos, servicios y bienes, en colaboración con las entidades y organizaciones de normalización y certificación y todos los agentes implicados" (BOE núm. 289 de 2003: 43191).

\subsubsection{Plan Nacional de I+D+I 2004-2007}

En cuanto a la Investigación y el Acceso a las Nuevas Tecnologías la Ley 16/2003 de 28 de mayo, de cohesión y calidad del Sistema Nacional de Salud, establece en su artículo 44 la responsabilidad

"del Estado en materia de investigación en salud, y sin periuicio de las competencias de las Comunidades Autónomas: establecer las medidas para que la investigación científica y la innovación contribuyan a mejorar de manera significativa y sostenible las intervenciones y procedimientos 
preventivos, diagnósticos, terapéuticos y rehabilitadores" (BOE núm.128 de 2003:20578).

Según la ley es el Ministerio de Sanidad y Consumo quien elabora la iniciativa sectorial de investigación en salud que se agrega al Plan Nacional de I+D+I. En el actual Plan Nacional de Investigación Científica, Desarrollo e Innovación Tecnológica 2004-2007 el único tema relacionado directamente con las personas discapacitadas que se considera dentro de los aspectos prioritarios es "Elementos urbanísticos accesibles para discapacitados (Programa Nacional de Tecnologías Sanitarias)".

El Plan Nacional se compone de programas nacionales, a su vez integrados por subprogramas. En el Área de Ciencias de la Vida y dentro del Programa Nacional de Tecnologías para la Salud y el Bienestar se encuentra el Subprograma Nacional de Tecnologías de apoyo a las personas con discapacidad y personas mayores.

Con el tema de la discapacidad también se relacionan el Programa Nacional de Medios de Transporte, los Programas Nacionales de Construcción y de Humanidades, el Programa Nacional de Biotecnología y el Programa Nacional de Tecnologías Informáticas.

Dentro del Subprograma de Tecnologías de Apoyo se clasifican las siguientes Ayudas Técnicas: para la valoración, tratamiento y rehabilitación, para la movilidad y ortoprotésica, para las personas con deficiencias visuales, para la audición, para las actividades de la vida diaria, accesibilidad a la información y a la comunicación, accesibilidad urbanística y en la edificación, accesibilidad al automóvil y a los medios de transporte, mobiliario adaptado y accesibilidad en el puesto de trabajo, cuyas definiciones podemos analizar en la siguiente figura. 
Ayudas técnicas para la valoración, tratamiento y rehabilitación

Desarrollo de nuevas ayudas técnicas para el tratamiento y la valoración, sistemas de valoración de la capacidad funcional y de la calidad de vida, así como técnicas de valoración objetiva de la discapacidad.

Ayudas técnicas para la movilidad y ortoprotésica

Desarrollo de ayudas técnicas para la movilidad personal, órtesis, exoprótesis, calzado ortopédico, y cojines y colchones antiescaras.

Ayudas técnicas para las personas con deficiencias visuales

Desarrollo de sistemas de percepción de imágenes y de recepción de información, y sistemas electro- informáticos táctiles y/o acústicos para personas con deficiencias visuales. Optimización de los sistemas tradicionales de impresión braille e investigación en lentes y fuentes de luz.

Ayudas técnicas para la audición (Prótesis Auditivas)

Investigación y desarrollo de implantes cocleares, sistemas de proceso y codificación de señales acústicas, sistemas informatizados para la adaptación personalizada de audífonos e implantes cocleares y desarrollo de estándares de medición y pruebas diagnósticas en estudios de audición.

Accesibilidad a la información y a la comunicación

Desarrollo de interfaces y dispositivos personales adaptativos, ayudas técnicas para la información, la comunicación y la señalización, desarrollo de software para facilitar el acceso a la educación, la información, la comunicación y el tiempo libre, sistemas de accesibilidad a la telefonía móvil y a la domótica.

Investigación en problemas de accesibilidad en dispositivos miniaturizados.

Accesibilidad urbanística y en la edificación

Investigación y desarrollo de elementos urbanísticos y mobiliario urbano accesible, ayudas técnicas y adaptaciones para la edificación -incluyendo la vivienda-, pavimentos adecuados a las necesidades de las personas con discapacidad y personas mayores, y aplicaciones y sistemas domóticos.

Ayudas técnicas para las actividades de la vida diaria (AVD)

Desarrollo de ayudas técnicas para las actividades de la vida diaria, ropa accesible y sistemas ergonómicos para la incontinencia.

Accesibilidad al automóvil y a los medios de transporte

Investigación y desarrollo en sillas de ruedas como asiento en todo tipo de vehículos automóviles, desarrollo de vehículos accesibles y de ayudas técnicas para vehículos, nuevos mandos de conducción para personas con discapacidad física, incluyendo sistemas inteligentes. Investigación en sistemas integradores de gestión del transporte público.

Mobiliario adaptado

Investigación y desarrollo de mobiliario doméstico adaptado, mobiliario adaptado a medida y mobiliario de oficina adaptado.

Accesibilidad en el puesto de trabajo

Investigación sobre necesidades de las personas con discapacidad para su integración laboral.

Investigación y desarrollo de adaptaciones ergonómicas del puesto de trabajo para personas con discapacidad y desarrollo de puestos de trabajo bajo planteamientos de "diseño para todos".

Tabla 2.2 Clasificación de las Ayudas Técnicas

Fuente: Plan Nacional de Investigación Científica, Desarrollo e Innovación Tecnológica 2004-2007 


\subsubsection{Ley de Dependencia}

El 23 de diciembre de 2005 el Consejo de Ministros aprobó el anteproyecto de la Ley de Promoción a la Autonomía Personal y Atención a las Personas Dependientes. Al presentar el anteproyecto, el ministro de de Trabajo y Asuntos Sociales, Jesús Caldera, señaló que está planificado que en 2007 la asistencia otorgada por la ley alcance a los "más necesitados", 200.000 personas que necesitan "ayuda para varias actividades básicas varias veces día y la presencia indispensable y continua de otra persona". Al año siguiente, 2008, se extendería a los afectados por "dependencia severa", los que "necesitan ayuda para realizar varias actividades básicas dos o tres veces al día" y, progresivamente en años siguientes, a los afectados de "dependencia moderada". ${ }^{5}$

Un año más tarde, el 15 de diciembre de 2006, se publica en el Boletín Oficial del Estado (BOE núm. 299) la Ley 39/2006, de 14 de diciembre, de Promoción a la Autonomía Personal y Atención a las Personas Dependientes. Mediante esta disposición se crea un Sistema Nacional de Dependencia con la colaboración y participación de todas las Administraciones Públicas.

En el Título Preliminar, Artículo 2, la Ley define la autonomía como "la capacidad de controlar, afrontar y tomar, por propia iniciativa, decisiones personales acerca de cómo vivir al día de acuerdo con las normas y preferencias propias así como de desarrollar las actividades básicas de la vida diaria".

La dependencia está definida como:

\footnotetext{
${ }^{5}$ Diario El País, Sociedad, 23/12/2005, http://www.elpais.com
} 
"el estado de carácter permanente en que se encuentran las personas que, por razones derivadas de la edad, la enfermedad o la discapacidad, y ligadas a la falta o a la pérdida de autonomía física, mental, intelectual o sensorial, precisan de la atención de otra $u$ otras personas o ayudas importantes para realizar actividades básicas de la vida diaria $\mathrm{o}$, en el caso de las personas con discapacidad intelectual $\circ$ enfermedad mental, de otros apoyos para su autonomía personal" (BOE núm. 299 de 2006:44144).

Por su parte, las actividades básicas de la vida diaria (ABVD) se refieren a

"las tareas más elementales de la persona, que le permiten desenvolverse con un mínimo de autonomía e independencia, tales como: el cuidado personal, las actividades domésticas básicas, la movilidad esencial, reconocer personas y objetos, orientarse, entender y ejecutar órdenes o tareas sencillas" (BOE núm. 299 de 2006:44144).

En el marco de esta ley se califica como personas con discapacidad a aquellas que tengan una minusvalía igual o superior al $33 \%$.

En el Título I, Capítulo 2, Artículo 13, presenta los objetivos de las prestaciones de dependencia que avala esta ley.

“a) Facilitar una existencia autónoma en su medio habitual todo el tiempo que desee y sea posible.

b) Proporcionar un trato digno, en todos los ámbitos de su vida personal, familiar y social, facilitando su incorporación activa en la vida de la comunidad" (BOE núm. 299 de 2006:44147).

En el siguiente artículo se menciona que las prestaciones de dependencia podrán ser servicios, prestaciones económicas o ayudas para la financiación de necesidades específicas. Los servicios contemplados por la 
ley son: Ayuda a Domicilio, Centro de Día y de Noche, Centro Residencial.

La ley considera además un Servicio de Teleasistencia (Artículo 22) para prestar ayuda mediante el uso de tecnologías de la comunicación y de la información, ante situaciones de emergencia, inseguridad, soledad o aislamiento.

En cuanto a la participación de las organizaciones de personas con discapacidad, la ley señala en el Capítulo IV, Artículo 40, que es el Comité Consultivo del Sistema para la Autonomía y Atención a la Dependencia el órgano asesor que debe informar, asesorar y formular propuestas. Este comité está adscrito al Ministerio de Trabajo y Asuntos Sociales.

En relación a la ayuda que la tecnología brinda a las personas en situación de dependencia, la ley se comprometería, en la Disposición adicional tercera, a apoyar económicamente en forma de subvenciones para "apoyar a la persona con ayudas técnicas o instrumentos necesarios para el normal desenvolvimiento de su vida ordinaria" y "facilitar la accesibilidad y adaptaciones en el hogar que contribuyan a mejorar su capacidad de desplazamiento en la vivienda" (BOE núm. 299 de 2006:44154).

Por último, en la Disposición adicional décima, de Investigación y Desarrollo, compromete la promoción de investigaciones en las áreas relacionadas con la dependencia en los planes de I+D+I. Señala, además, que "las Administraciones Públicas facilitarán y apoyarán el desarrollo de normativa técnica de modo que asegure la no discriminación en procesos, diseños y desarrollos de tecnologías, productos y servicios en colaboración con las organizaciones de 
normalización y todos los agentes implicados" (BOE núm. 299 de 2006:44154).

\subsection{La discapacidad en la sociedad}

La Encuesta sobre Discapacidades, Deficiencias y Estado de Salud (EDDES) realizada por el Instituto Nacional de Estadística (INE) en 1999 señala que de las 39.247 .010 personas que constituían la población española en el momento de la encuesta, 3.528.222 declararon algún tipo de discapacidad o limitación, es decir, una tasa de prevalencia de un $9,0 \%$.

La tasa de prevalencia de discapacidad es el número de individuos que sufren esta circunstancia de forma duradera (más de un año) sobre el conjunto de la población. Se reserva el término discapacidad para hablar de las dificultades de la población de 6 y más años para realizar actividades (36 posibles tipos de discapacidad), y el de limitaciones para los/as niños/as de 0-5 (14 tipos de limitaciones).

En el libro, que publica los resultados y análisis de esta encuesta, se expresa el hecho, recogido también en estudios anteriores, de que "la discapacidad es una manifestación muy concreta de los problemas de salud, y en la opinión pública no ocupa un lugar excesivamente destacado como problema" (INE 2000:12). Se une a este diagnóstico la realidad histórica y socioeconómica de España y países más desarrollados en los que las fuentes estadísticas sobre la discapacidad son recientes. En la encuesta se hace referencia a un estudio de Durán Heras ${ }^{6}$ que en un anexo enumera y comenta de forma exhaustiva las fuentes existentes,

${ }^{6}$ Durán Heras, M. Á. 2002, Los costes invisibles de la enfermedad, Bilbao: Fundación BBVA. 
demostrando que antes de la década de los noventa prácticamente no existen fuentes estadísticas significativas.

La Discapacidad en España, 1999

\begin{tabular}{|c|c|c|c|}
\hline Edad & $\begin{array}{l}\text { Personas con } \\
\text { Discapacidad }\end{array}$ & $\begin{array}{l}\text { Población total } \\
\text { nacional }\end{array}$ & $\begin{array}{l}\text { Tasas } \\
\text { discapacidad (\%) }\end{array}$ \\
\hline 0 a 5 & 49.577 & 2.209 .504 & 2,2 \\
\hline 6 a 9 & 29.784 & 1.576 .852 & 1,9 \\
\hline 10 a 14 & 31.554 & 2.139 .799 & 1,5 \\
\hline 15 a 19 & 51.237 & 2.721 .775 & 1,9 \\
\hline 20 a 24 & 59.048 & 3.185 .063 & 1,9 \\
\hline 25 a 29 & 78.275 & 3.309 .305 & 2,4 \\
\hline 30 a 34 & 107.632 & 3.223 .414 & 3,3 \\
\hline 35 a 39 & 115.171 & 3.025 .008 & 3,8 \\
\hline 40 a 44 & 115.079 & 2.715 .952 & 4,2 \\
\hline 45 a 49 & 135.074 & 2.435 .621 & 5,5 \\
\hline 50 a 54 & 170.834 & 2.326 .381 & 7,3 \\
\hline 55 a 59 & 210.964 & 1.982 .867 & 10,6 \\
\hline 60 a 64 & 301.341 & 1.960 .947 & 15,4 \\
\hline 65 a 69 & 368.338 & 2.028 .910 & 19,0 \\
\hline 70 a 74 & 457.269 & 1.732 .278 & 26,4 \\
\hline 75 a 79 & 476.927 & 1.293 .297 & 36,9 \\
\hline 80 a 84 & 370.701 & 780.563 & 47,5 \\
\hline 85 y más & 381.417 & 599.474 & 63,6 \\
\hline Total & 3.528 .222 & 39.247 .010 & 9,0 \\
\hline Total 6+ & 3.478 .645 & 37.037 .506 & 9,4 \\
\hline Total $65+$ & 2.072 .652 & 6.434 .522 & 32,2 \\
\hline
\end{tabular}

Tabla 2.3 Estadísticas de la Discapacidad en España en 1999

Fuente: Encuesta sobre Discapacidades, Deficiencias y Estado de Salud, Instituto Nacional de Estadísticas (INE), 1999.

Las discapacidades referidas a la movilidad, aquellos que limitan el espacio vivido, son las más frecuentes entre la población española. Según la Encuesta sobre discapacidades, deficiencias y estado de salud (EDDES) las mujeres sufren en mayor medida que los hombres este tipo de problemas de movilidad y casi dos de cada tres individuos con esta discapacidad son personas de edad avanzada. 
Casi dos tercios de las personas que declaran alguna discapacidad tienen dificultades para desplazarse fuera del hogar. Esta discapacidad de movilidad incluye fundamentalmente el poder utilizar el transporte público $(45 \%)$ y deambular $\sin$ medio de transporte $(41,3 \%$ ). Los problemas referidos al desplazamiento en transportes públicos afectan en mayor medida a las mujeres (INE 1999).

Según el informe de la EDDES hay 33 deficiencias que pueden agruparse en 8 categorías:

- mentales

- visuales

- del oído

- del lenguaje

- habla y voz

- osteoarticulares

- del sistema nervioso

- viscerales

- otras deficiencias (incluyen las múltiples)

Las deficiencias son los síntomas, señales o manifestación de una enfermedad o accidente a nivel del órgano, cualquiera que sea la causa. Cada una de estas deficiencias origina una o más discapacidades, ya que es "cualquier anomalía o pérdida de un órgano o de la función propia de ese órgano". Toda discapacidad tiene origen en una deficiencia y toda deficiencia tiene su origen en un problema. 
Problemas que causan deficiencias

\begin{tabular}{|c|c|c|c|c|c|c|c|}
\hline \multirow[t]{2}{*}{$\begin{array}{l}\text { Problema de } \\
\text { origen }\end{array}$} & \multicolumn{6}{|l|}{ Edad } & \multirow[t]{2}{*}{$\begin{array}{l}\text { Total } \\
\text { deficiencias }\end{array}$} \\
\hline & 6 a 19 & 20 a 44 & 45 a 64 & 65 a 79 & $80+$ & Total & \\
\hline Congénito & 45,6 & 26,2 & 7,3 & 2,6 & 1,0 & 7,0 & 342.170 \\
\hline $\begin{array}{l}\text { parto } \\
\text { Accidente de }\end{array}$ & 15,2 & 7,0 & 1,1 & 0,1 & 0,0 & 1,5 & 72.376 \\
\hline tráfico & 2,0 & 5,8 & 2,7 & 1,3 & 0,5 & 1,9 & 93.351 \\
\hline $\begin{array}{l}\text { Accidente } \\
\text { doméstico } \\
\text { Accidente de }\end{array}$ & 1,8 & 1,5 & 1,7 & 1,8 & 2,2 & 1,9 & 91.157 \\
\hline $\begin{array}{l}\text { ocio } \\
\text { Accidente }\end{array}$ & 0,4 & 1,9 & 1,4 & 0,7 & 0,4 & 0,9 & 44.051 \\
\hline laboral & 0,0 & 5,2 & 6,3 & 2,3 & 0,8 & 3,0 & 149.036 \\
\hline $\begin{array}{l}\text { Otro tipo de } \\
\text { accidente } \\
\text { Enfermedad }\end{array}$ & 1,1 & 3,4 & 1,8 & 1,7 & 1,8 & 1,9 & 94.811 \\
\hline $\begin{array}{l}\text { común } \\
\text { Enfermedad }\end{array}$ & 19,0 & 35,2 & 60,3 & 69,2 & 64,0 & 60,8 & 2.973 .802 \\
\hline profesional & 0,1 & 1,7 & 5,1 & 2,3 & 0,9 & 2,4 & 118.447 \\
\hline Otras causas & 13,2 & 11,8 & 12,3 & 17,6 & 27,8 & 18,2 & 891.478 \\
\hline $\mathrm{ns} / \mathrm{nc}$ & 1,6 & 0,3 & 0,1 & 0,3 & 0,6 & 0,4 & 17.649 \\
\hline Total & 100,0 & 100,0 & 100,0 & 100,0 & 100,0 & 100,0 & 4.888.328 \\
\hline
\end{tabular}

Tabla 2.4 Problemas que causan deficiencias

Fuente: Encuesta sobre Discapacidades, Deficiencias y Estado de Salud, Instituto Nacional de Estadísticas (INE), 1999.

Dentro de las deficiencias, sobresale por número de afectados/as y edad de aparición la de tipo osteoarticular, que dan origen a las discapacidades de movilidad, especialmente las que afectan a las extremidades inferiores y la columna (malformaciones, y secuelas de traumatismos, reumatismos y otras alteraciones). Destacan en este grupo las tetraplejias y paraplejias, aunque entre las restricciones de movilidad intervienen también deficiencias del sistema nervioso, mentales o procesos degenerativos, por ejemplo. 


\section{3 Discapacidad y Ciencia y Tecnología}

Al hablar de I+D+I al servicio de las personas discapacitadas, abarcamos toda investigación científica, desarrollo e innovación tecnológica que ayude de una u otra manera a la integración social, autonomía personal, independencia, salud y calidad de vida de este colectivo.

En el año 2003, Año Europeo de la Discapacidad, el Ministerio de Trabajo y Asuntos Sociales (CEAPAT-IMSERSO) y el Instituto de Biomecánica de Valencia publicaron el "Libro Blanco de I+D+I al Servicio de las Personas con Discapacidad y las Personas Mayores". Esta publicación ha permitido conocer el estado actual del sector de un sector tecnológico íntimamente ligado a las personas con discapacidad.

Este sector está configurado por los campos de las Tecnologías de la Rehabilitación (TR), también llamado Tecnologías de Apoyo a la Discapacidad (TADIS), que agrupan a todas aquellas áreas científicotécnicas que pueden aportar soluciones a los problemas de la accesibilidad. 


\subsubsection{Tecnologías de Apoyo a la Discapacidad}

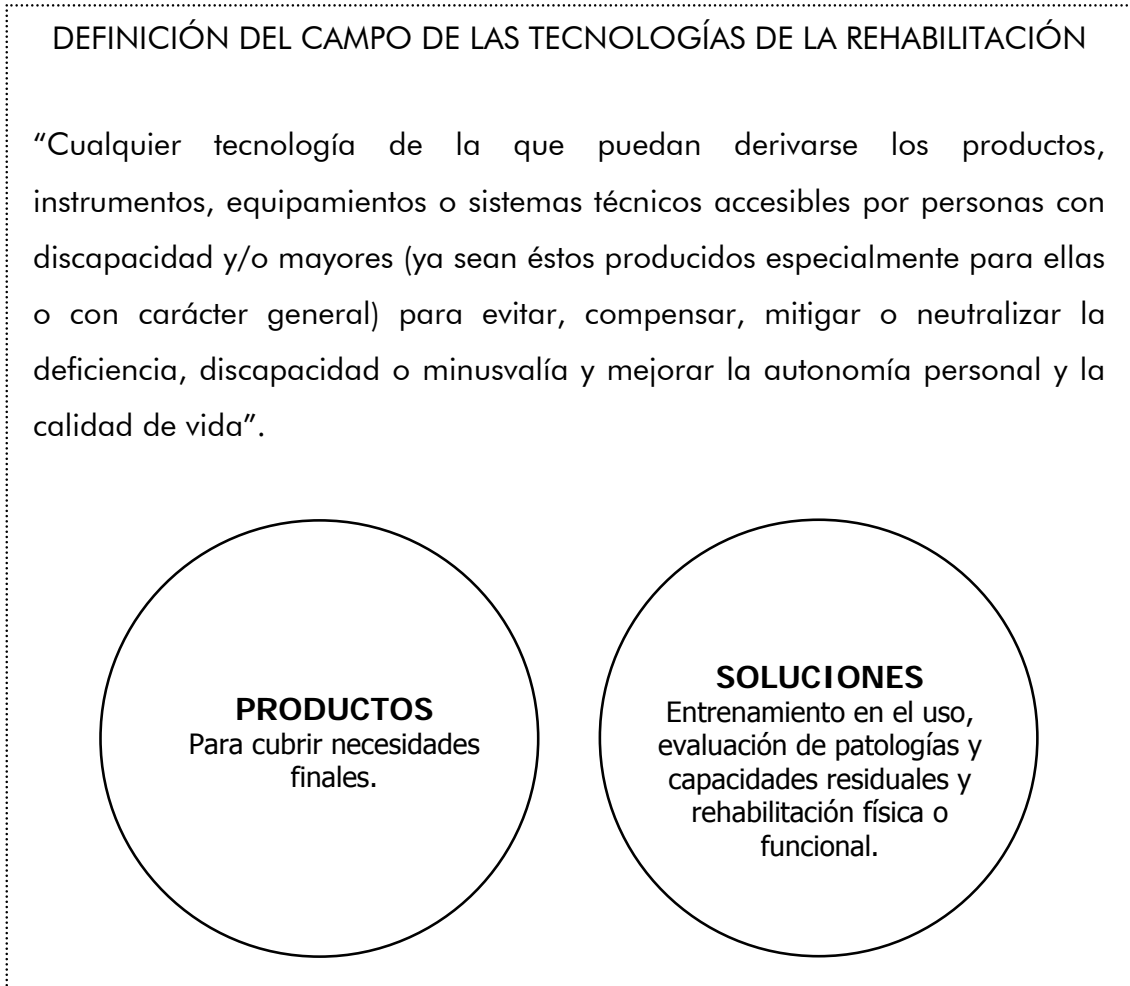

Fig. 2.1 Definición del campo de las Tecnologías de la Rehabilitación Fuente: Libro Blanco de I+D+I al Servicio de las Personas con Discapacidad y Personas Mayores.

En materia de diseño, la accesibilidad se define "como el resultado de la aplicación de soluciones técnicas al diseño de nuestro entorno en cualquiera de sus distintas áreas: arquitectura, urbanismo, dispositivos, sistemas, productos o servicios, desarrollo de soffware, que permita a los usuarios $O$ consumidores manejar productos $y / o$ servicios con independencia de sus limitaciones funcionales" (CEAPAT-IMSERSO, IBV, 2003). 
Según la norma UNE-EN ISO 99997 ${ }^{7}$, se consideran como Ayudas para la Terapia y el Entrenamiento:

a) Ayudas para la terapia respiratoria.

b) Ayudas para la terapia circulatoria.

c) Ayudas para hernia abdominal.

d) Ayudas para diálisis.

e) Equipos y materiales para pruebas físicas, fisiológicas y bioquímicas.

f) Estimuladores.

g) Termoterapia y crioterapia.

h) Ayudas para la tracción espinal.

i) Equipos para el entrenamiento del movimiento, la fuerza y el equilibrio.

i) Ayudas para el aprendizaje de la continencia.

k) Material de entretenimiento y ocio en rehabilitación (juegos, por ejemplo).

Quedarían también incluidas las siguientes, exceptuando productos tipo software:

l) Ayudas para terapia, entrenamiento y aprendizaje de la comunicación.

m) Ayudas para el entrenamiento/aprendizaje en comunicación alternativa y aumentativa.

n) Ayudas para el entrenamiento de las capacidades cognitivas.

o) Ayudas para el entrenamiento/aprendizaje de tareas básicas.

p) Diversas ayudas técnicas para la educación.

q) Ayudas para el entrenamiento en el control de dispositivos de entrada al PC.

r) Ayudas para el entrenamiento de la percepción.

En términos generales, entre las tecnologías desarrolladas por cada sector las más demandadas (utilizadas por más del 25\% de las personas con discapacidad) se encuentran en los sectores de las ayudas técnicas para el

\footnotetext{
${ }^{7}$ Norma Europea EN ISO 9999, de octubre de 2002.
} 
desplazamiento, para el entrenamiento, para la protección y el cuidado personal, entre las prótesis y órtesis y los dispositivos para las tareas domésticas.

Los siguientes productos, demandados por menos de un $25 \%$ y más de un 10\% de los discapacitados, son los referentes a la comunicación, la información y la señalización y el mobiliario adaptado. Finalmente, los solicitados por menos del $10 \%$ están los productos dedicados al ocio y el esparcimiento, manejar objetos y las adaptaciones de la vivienda.

Consumo de ayudas técnicas por clase de ayuda, en porcentaje de la población

Clases de ayudas técnicas utilizadas por personas con múltiples limitaciones en sus actividades

Ayudas para desplazarse

Ayudas para entrenar y mejorar

Ayudas para su protección, aseo y cuidado personal

Prótesis u órtesis

Ayudas para realizar tareas domésticas

Ayudas para comunicarse, informarse y señalizar

Mobiliario adaptado

Ayudas para el ocio y esparcimiento

Ayudas para manejar y sujetar objetos

Adaptaciones de la vivienda

Otras ayudas técnicas

Tabla 2.5 Consumo de ayudas técnicas

Fuente: Libro Blanco de I+D+I al Servicio de las Personas con Discapacidad y Personas Mayores.
Porcentaje de casos

61,1

38,9

32,0

28,3

25,9

14,6

14,6

8,5

8,1

7,7

21,5

Según el tipo de discapacidad, cada grupo utiliza la ayuda técnica que mejor cubre sus respectivas necesidades. En el caso de las discapacidades referidas a la movilidad, las ayudas más utilizadas son las empleadas para realizar tareas domésticas, trasladarse fuera del hogar y vestirse. Las personas que tienen discapacidad auditiva y del habla demandan casi en su totalidad y exclusivamente ayudas para la comunicación. Según el "Libro Blanco de I+D+I al servicio de las Personas con Discapacidad", 
destaca la escasa utilización del ordenador como ayuda para la terapia y el entrenamiento entre este grupo.

Principales tipos de ayudas técnicas utilizadas

\begin{tabular}{|c|c|c|}
\hline $\begin{array}{l}\text { Tipo de } \\
\text { discapacidad }\end{array}$ & Clase de ayuda técnica utilizada & $\begin{array}{l}\text { Porcentaje de } \\
\text { personas que la } \\
\text { utilizan* }\end{array}$ \\
\hline \multirow{4}{*}{$\begin{array}{l}\text { Discapacidad } \\
\text { motora en las } \\
\text { extremidades } \\
\text { inferiores }\end{array}$} & Ayudas para trasladarse fuera del hogar & 63,2 \\
\hline & $\begin{array}{l}\text { Ayudas para realizar las tareas } \\
\text { domésticas }\end{array}$ & 50,0 \\
\hline & $\begin{array}{l}\text { Ayudas para la protección, el aseo y el } \\
\text { cuidado personal }\end{array}$ & 36,8 \\
\hline & $\begin{array}{l}\text { Ayudas para trasladarse dentro del } \\
\text { hogar }\end{array}$ & 34,2 \\
\hline \multirow{3}{*}{$\begin{array}{l}\text { Discapacidad } \\
\text { motora en las } \\
\text { extremidades } \\
\text { superiores }\end{array}$} & $\begin{array}{l}\text { Ayudas para realizar las tareas } \\
\text { domésticas }\end{array}$ & 66,7 \\
\hline & Ayudas para vestirse & 50,0 \\
\hline & Ayudas para comer & 33,3 \\
\hline \multirow{2}{*}{$\begin{array}{l}\text { Discapacidad } \\
\text { auditiva y del } \\
\text { habla }\end{array}$} & Ayudas para la comunicación & 89,0 \\
\hline & $\begin{array}{l}\text { Ayudas para la terapia y el } \\
\text { entretenimiento }\end{array}$ & 11,5 \\
\hline \multicolumn{2}{|c|}{ Tabla 2.6 Ayudas técnicas utilizadas } & $\begin{array}{l}\text { * de la población tota } \\
\text { de cada grupo }\end{array}$ \\
\hline
\end{tabular}

\subsubsection{El sector tecnológico de las Tecnologías de Rehabilitación (TR)}

El sector de las tecnologías de rehabilitación es complejo de analizar. Por una parte la información disponible es escasa $y$, en muchas ocasiones, desfasada de la actual situación del sector. La gran cantidad y variedad de mercados que intervienen, la fragmentación de la oferta y la demanda, la diversidad de financiadores, la poca estadística oficial y la existencia de pocas organizaciones empresariales del sector en el ámbito nacional son algunos de los factores que dificultan el estudio (COTEC 1999). 
Como hemos señalado en el punto anterior, el sector de las tecnologías de la rehabilitación reúne a aquellas tecnologías de las que se puedan derivar productos accesibles por personas con discapacidad y/o personas mayores. Este conjunto de tecnologías pueden ser clasificadas, según en grado de adaptación requerida en:

a) Diseño para todos: productos y servicios de gran consumo, dirigidos al público en general, con un diseño que permita la accesibilidad al mayor número de personas, sin introducir barreras.

b) Ayudas Técnicas: productos y servicios dirigidos a solucionar un problema de accesibilidad generado por la existencia de una discapacidad, que no puede ser solventado con productos de uso corriente, siendo necesario el diseño o creación de aplicaciones concretas (COTEC 1999).

Los campos tecnológicos relacionados con el sector de las TR con mayor fuerza son las tecnologías mecánica, eléctrica, electrónica, hidráulica, de materiales, metalúrgica, de control, de la instrumentalización, de vehículos a motor, textil, de la información, de las telecomunicaciones, de la construcción, biotecnología, planificación urbana y procesos tecnológicos, entre otros. 
2.3.2.1 Agentes sociales y económicos implicados en las TR

En el sector de las tecnologías de la rehabilitación participan los siguientes agentes:

- Usuarios

- Profesionales

- Empresas

- Administraciones Públicas

Usuarios

No todos los usuarios de ayudas técnicas tienen las mismas necesidades, por lo tanto, no todos demandan los mismos productos. Al existir un abanico tan amplio de tipos de discapacidad, existe también una gran gama de productos diseñados para ayudar, compensar $\circ$ mitigar determinada deficiencia.

De lo anteriormente señalado se desprende que el número de usuarios de cada ayuda técnica representa, en la mayoría de los casos, un porcentaje muy pequeño en relación al total de usuarios de estas tecnologías en su conjunto.

Entre los usuarios del mercado de las tecnologías de la rehabilitación podemos diferenciar tres grupos, según el Comité Español de Representantes de Personas con Discapacidad, CERMI (2005):

1. Personas con discapacidad permanente

2. Personas con discapacidad temporal

3. Personas mayores 
Si consideramos que según la encuesta del INE de 1999, en España hay más de 3 millones y medio de personas con discapacidad, nos percatamos de que el número de usuarios de estas tecnologías sería superior a esa cifra, ya que en ella no se consideran las personas que recurren de manera eventual a las ayudas técnicas por una deficiencia o enfermedad transitoria.

\section{Profesionales}

Hemos visto la variedad de tecnologías implicadas en el sector de las tecnologías de la rehabilitación. De igual manera es elevado el número de profesionales que participan en las diferentes etapas de prescripción, fabricación, distribución, venta y entrenamiento de las ayudas técnicas.

Estrechamente relacionados con esta área están, entre otros, técnicos ortopédicos, médicos rehabilitadores, médicos traumatólogos, audioprotesistas, logopedas, fisioterapeutas, terapeutas ocupacionales y trabajadores sociales.

Las diferentes tareas que desarrolla cada profesional se complementan a lo largo de un proceso que va desde prescribir o recomendar determinada ayuda técnica, controlar y evaluar el uso, entrenar y apoyar en la utilización, así como diseñar, fabricar y adaptar los aparatos, sin olvidar a los profesionales que se encargan de informar de la existencia y formas de adquisición y financiación de cada producto.

\section{Empresas}

Según datos del CERMI, hay alrededor de 1.900 empresas dentro del sector de las tecnologías de la rehabilitación en España, de las cuales cerca de 200 son fabricantes y distribuidoras de productos fabricados en 
serie. Las demás empresas son ortopedias PYMES y micro-PYMES, pequeños comercios con límites geográficos. (CERMI 2005)

La producción española, que alcanza los 120 millones de euros, cubre sólo el $50 \%$ de la demanda interna, importándose el resto de EE.UU., Alemania, Reino Unido y Francia.

En su análisis, el CERMI destaca, además, la escasa inversión en I+D del sector en el ámbito nacional, siendo la tónica asimilar innovaciones extranjeras o adaptar productos utilizando tecnología importada.

Administraciones Públicas

En España, el Centro Estatal de Autonomía Personal y Ayudas Técnicas (CEAPAT), dependiente del Instituto de Migraciones y Servicios Sociales (IMSERSO), del Ministerio de Trabajo y Asuntos Sociales, se encarga de coordinar los campos tecnológico y social.

Según el Plan Nacional de I+D+I 2004-2007 el gasto sanitario en España asciende a $36.900 \mathrm{M} €$. De esto, el 8,13\% (3.000 M€) se destinan al mercado de Tecnología Sanitaria. Las cifras presentadas en este Plan indican que, al igual que en el sector específico de las tecnologías de la rehabilitación, existe una gran dependencia tecnológica, ya que sólo el $20 \%$ de los productos son de fabricación nacional.

Por otra parte, según datos de la Federación Española de Ortesistas y Protesistas (FEDOP) recogidos por el CERMI, el volumen de mercado del sector TR fue en España en el año 2001 de más de 300 millones de euros. De esta cantidad, alrededor de 110 millones de euros correspondieron a gasto de la sanidad pública española. El resto, más de 250 millones de euros, fueron generados por el mercado privado. 


\subsection{Producción científica española referida a las personas con discapacidad y la tecnología}

El punto de partida de esta investigación es el análisis de la producción científica que aborda la relación entre la tecnología y la discapacidad; ya que, a través de él, se muestra un mapa del estado de la investigación española en el tema de la discapacidad y la tecnología; investigación que brinda sustento al desarrollo del uso de las tecnologías al servicio de las personas con discapacidad, y a la innovación en esta área.

Para llevar a cabo el estudio se ha obtenido la producción científica española en cuanto a la discapacidad relacionada con alguna de estas categorías: tecnologías de ayuda, ayudas técnicas, tecnología y discapacidad. La recopilación de los datos conllevó ciertas dificultades ya que la presencia de publicaciones españolas referidas a este tema en fuentes de prestigio internacional y de rigurosidad científica es escasa. Por lo tanto, la búsqueda se amplió a bases de datos que recogieran publicaciones que no han pasado por un sistema de control estricto. Se realizó un rastreo en Internet en diferentes bases de datos y páginas web relacionadas con el tema de la discapacidad, que ya tuvieran agrupada cierta producción científica de este campo.

\subsubsection{Fuentes consultadas}

Las fuentes de las que se obtuvieron los datos fueron las siguientes:

\section{a) TECNONEET:}

Página web del Foro de Tecnología Educativa y Atención a la 
Diversidad $^{8}$, creado por la Consejería de Educación y Cultura de la Región de Murcia (España), que recoge las ponencias de los Congresos Tecnoneet, encuentros cada dos años a partir del año 2000.

- I Congreso Nacional de Nuevas Tecnologías y Necesidades Educativas Especiales. Nuevas Tecnologías, Viejas Esperanzas. (22, 23, 24 y 25 de junio de 2000).

- II Congreso Nacional de Nuevas Tecnologías y Necesidades Educativas Especiales. "Las Tecnologías de Ayuda en la respuesta educativa a la diversidad" (19, 20 y 21 de septiembre de 2002).

- III Congreso Nacional de Tecnología, Educación y Diversidad. (23 al 25 de septiembre de 2004).

- Además se incluyen publicaciones y documentos relacionados con el ámbito de las Tecnologías de la Información y Comunicación y la atención a la diversidad, cuyos autores han autorizado su incorporación en el Foro Tecnoneet.

b) IMSERSO:

Proyectos de investigación y estudios financiados por el Instituto de Mayores y Servicios Sociales ${ }^{9}$ del Ministerio de Trabajo y Asuntos Sociales.

8 http://www.tecnoneet.org

${ }^{9}$ http://www.seg-social.es/imserso/ 


\section{c) CINDOC:}

Centro de Información y Documentación Científica (CINDOC) ${ }^{10}$ del Consejo Superior de Investigaciones Científicas (CSIC) que reúne las bases de datos bibliográficas ICYT (publicaciones españolas de ciencia y tecnología), ISOC (ámbito de las ciencias sociales y humanas) e IME (Biomedicina), las cuales contienen la producción científica publicada en España desde los años 70. Recogen fundamentalmente artículos de Revistas científicas y de forma selectiva Actas de congresos, Series, Compilaciones, Informes y Monografías.

d) ACCESO:

Página web de la Unidad de Investigación Acceso" ${ }^{11}$, grupo de investigación de la Universitat de València, cuyas líneas de investigación son: Diseño para Todos (Design for all) de entornos de aprendizaje, e_learning y accesibilidad a la red, tecnologías de ayuda, Evaluación psicoeducativa, e Integración educativa y socio-laboral de personas con minusvalías. Esta página contiene proyectos de investigación y publicaciones de este grupo de trabajo.

e) DIALNET

DIALNET $^{12}$ es un servicio de Alertas Informativas y de acceso a los contenidos de la literatura científica hispana, gestionado por la Universidad de la Rioja, que permite acceder a 3.332 revistas,

\footnotetext{
10 http://www.cindoc.csic.es/

11 http://acceso.uv.es/

12 http://dialnet.unirioja.es/
} 
75.802 ejemplares, 9.846 monografías colectivas y 934.254 artículos.

\section{f) ISI WEB OF KNOWLEDGE}

ISI Web of Knowledge Web of Science ${ }^{13}$ contiene información bibliográfica multidisciplinaria de alta calidad publicada en revistas líderes mundiales en las ciencias, ciencias sociales, artes y humanidades. Abarca las bases de datos: Science Citation Index Expanded, Social Science Citation Index y Arts and Humanities Citation Index.

\section{g) CEAPAT}

El Centro Estatal de Autonomía Personal y Ayudas Técnicas ${ }^{14}$, CEAPAT, es un centro tecnológico dependiente del IMSERSO, Ministerio de Trabajo y Asuntos Sociales. En su Centro Documental recoge los documentos y publicaciones del CEAPAT, o en cuya elaboración ha participado el centro, así como otras publicaciones de interés en los ámbitos de la tecnología de apoyo, la accesibilidad integral y el diseño para todos.

Cada una de las fuentes consultada entregaba diferente información de cada publicación o proyecto (Tabla 1), por lo tanto para unificar los criterios, lo primero fue determinar unas categorías transversales que pudieran ser recogidas en todas las fuentes. Las categorías de la base de datos final son:

1. AÑO: año de publicación

\footnotetext{
${ }^{13} \mathrm{http}$ ://portal.isiknowledge.com/portal.cgi?Init=Yes\&SID=V1ba8K@fOmDPGjNBEB@

$14 \mathrm{http}: / /$ www.ceapat.org
} 
2. FUENTE: base de datos o página web desde dónde se ha obtenido la información.

3. REVISTA/LIBRO/CONGRESO: nombre de la revista o título del libro o congreso donde se ha generado la información.

4. TIPO: tipo de producción científica. Puede ser: libro, parte de libro, artículo de revista, conferencia congreso, estudio, proyecto de investigación.

5. CLASIFICACIÓN TEMÁTICA: tema que estudia, analiza o al que se refiere la producción científica. ${ }^{15}$

6. TíTULO: título de la producción científica.

7. PARTICIPANTE: autor o investigador, hasta 15, cada uno en una celda independiente. $\left(^{*}\right)$

8. INSTITUCIÓN: universidad, centro, empresa, asociación, organismo, fundación, hospital, museo, profesión o actividad de cada participante. $\left({ }^{*}\right)\left({ }^{* *}\right)$

\footnotetext{
(*) No se refleja la relación de cada participante con su institución.

$\left.{ }^{* *}\right)$ En una base de datos adicional se clasifican las Instituciones por tipo.

${ }^{15}$ Cfr. p. 57 para ver las diferentes temáticas.
} 


\section{Categorías de las fuentes consultadas}

\begin{tabular}{|c|c|c|c|c|c|c|}
\hline CINDOC & ISI & DIALNET & ACCESO & CEAPAT & TECNONEET & IMSERSO \\
\hline $\begin{array}{l}\text { Núm } \\
\text { Registro }\end{array}$ & $\begin{array}{l}\text { PT (Tipo de } \\
\text { publicación) }\end{array}$ & Título & $\begin{array}{l}\text { Tipo de } \\
\text { registro }\end{array}$ & Título & Fecha & Fecha \\
\hline Autores & AU (Autor) & Autores & Autores & Autor & Título & Título \\
\hline $\begin{array}{l}\text { Tít. en } \\
\text { español }\end{array}$ & $\begin{array}{l}\text { CA (Grupo de } \\
\text { Investigación) }\end{array}$ & $\begin{array}{l}\text { ISSN de } \\
\text { la revista }\end{array}$ & Título & Fecha & Revista & Participantes \\
\hline $\begin{array}{l}\text { Tít. en } \\
\text { inglés }\end{array}$ & TI (Título) & $\begin{array}{l}\text { Título } \\
\text { Revista }\end{array}$ & Congreso & Institución & Participantes & Institución \\
\hline Congreso & SO (Fuente) & Referencia & $\begin{array}{l}\text { Título } \\
\text { Revista } \\
\end{array}$ & & Institución & \\
\hline $\begin{array}{l}\text { Lugar de } \\
\text { trabajo }\end{array}$ & $\begin{array}{l}\text { SE (Título de la } \\
\text { Serie de Libros) }\end{array}$ & $\begin{array}{l}\text { Lugar de } \\
\text { trabajo }\end{array}$ & Referencia & & & \\
\hline $\begin{array}{l}\text { ISSN de la } \\
\text { revista }\end{array}$ & LA (Idioma) & & Libro & & & \\
\hline $\begin{array}{l}\text { Título } \\
\text { Revista }\end{array}$ & $\begin{array}{l}\text { DT (Tipo de } \\
\text { Documento) }\end{array}$ & & & & & \\
\hline $\begin{array}{l}\text { Datos } \\
\text { fuente }\end{array}$ & $\begin{array}{l}\text { DE } \\
\text { (Descriptores) }\end{array}$ & & & & & \\
\hline Lengua & $\begin{array}{l}\text { ID (Palabras } \\
\text { claves } \\
\text { adicionales) }\end{array}$ & & & & & \\
\hline $\begin{array}{l}\text { Clasif. } \\
\text { Unesco }\end{array}$ & $\mathrm{AB}$ (Abstract) & & & & & \\
\hline Clasif. texto & $\begin{array}{l}\text { C1(Lugar de } \\
\text { trabajo) }\end{array}$ & & & & & \\
\hline Descriptores & $\begin{array}{l}\text { RP (Dirección } \\
\text { de reimpresión) }\end{array}$ & & & & & \\
\hline Editor & EM (email) & & & & & \\
\hline \multirow[t]{12}{*}{ CopyRight } & $\begin{array}{l}\text { CR (Citas } \\
\text { utilizadas) }\end{array}$ & & & & & \\
\hline & $\begin{array}{l}\text { NR ( } N \text { o de citas } \\
\text { utilizadas) }\end{array}$ & & & & & \\
\hline & $\begin{array}{l}\text { TC (№ de citas } \\
\text { recibidas) }\end{array}$ & & & & & \\
\hline & PU (Editorial) & & & & & \\
\hline & $\begin{array}{l}\text { PI (Ciudad de } \\
\text { Publicación) }\end{array}$ & & & & & \\
\hline & $\begin{array}{l}\text { PA (Dirección } \\
\text { de Publicación) }\end{array}$ & & & & & \\
\hline & SN (ISSN) & & & & & \\
\hline & $\begin{array}{l}\text { J9 (Abreviatura } \\
\text { del Título de la } \\
\text { Fuente de } 29 \\
\text { caracteres) }\end{array}$ & & & & & \\
\hline & $\begin{array}{l}\text { Jl (Abreviatura } \\
\text { del Título de la } \\
\text { Fuente) }\end{array}$ & & & & & \\
\hline & $\begin{array}{l}\text { PD (Fecha de } \\
\text { publicación) }\end{array}$ & & & & & \\
\hline & $\begin{array}{l}\text { PY (Año de } \\
\text { publicación) }\end{array}$ & & & & & \\
\hline & VL (Volumen) & & & & & \\
\hline
\end{tabular}




\begin{tabular}{ll}
\hline & PN (Número de \\
Parte) \\
\hline SU \\
(Suplemento) \\
\hline SI (Edición \\
Especial) \\
\hline BP (Página de \\
Inicio) \\
\hline EP (Última \\
Página) \\
\hline AR (Número del \\
artículo de los \\
diarios nuevos \\
del APS) \\
\hline DI (Identificador \\
Digital de \\
Objeto) \\
\hline PG (Número de \\
Páginas) \\
\hline SC (Categoría \\
temática) \\
\hline GA (No de \\
entrega de \\
documentos del \\
ISI) \\
\hline UT (Código de \\
ISI) \\
\hline Categorias de las fuentes consultadas parala recopilación de la producción
\end{tabular}

Tabla 2.7 Categorías de las fuentes consultadas para la recopilación de la producción científica española

Se recopilaron todas las publicaciones ya fueran artículos de revistas, libros, partes de libro, conferencias de congresos, estudios y/o proyectos de investigación en las fuentes mencionadas. Al hacer las búsquedas se encontró un total de 3.754 publicaciones referidas a la discapacidad (Tabla 2.8), de los cuales sólo 407, un 10,84\% tiene como temática principal o guardan alguna relación entre discapacidad y tecnología. 


\begin{tabular}{lcccc}
\hline Fuente & $\begin{array}{c}\text { Registros } \\
\text { totales de } \\
\text { "discapacidad" }\end{array}$ & $\begin{array}{c}\text { Registros } \\
\text { referidos a } \\
\text { discapacidad } \\
\text { y tecnología }\end{array}$ & $\begin{array}{c}\text { Porcentaje de } \\
\text { registros de } \\
\text { DyT respecto } \\
\text { del total }\end{array}$ & Período de tiempo \\
\hline $\begin{array}{l}\text { IMSERSO } \\
\text { estudios }\end{array}$ & 30 & 5 & 16,67 & $1993-2004$ \\
ISI Web of & 669 & 13 & 1,94 & $1982-2006$ \\
Knowledge & 75 & 32 & 42,67 & $1989-2006$ \\
CEAPAT & 52 & 36 & 69,23 & $1997-2006$ \\
ACCESO & 1677 & 42 & 2,50 & $1982-2006$ \\
DIALNET & 1024 & 64 & 6,25 & $1970-2006$ \\
CINDOC & 227 & 215 & 94,71 & $2000-2004$ \\
Tecnoneet & 3754 & 407 & 10,84 & \\
\hline Total & & 64 & &
\end{tabular}

Tabla 2.8 Publicaciones referidas a discapacidad

Como se puede apreciar en la tabla, no existe uniformidad temporal, esto es no todas las fuentes entregan información del mismo período de tiempo. La información recogida va desde 1982 hasta octubre de 2006. La fuente que cubre una mayor cantidad de años es el CINDOC, pero su aporte de registros referidos a discapacidad y tecnología en comparación al total sobre discapacidad, es muy bajo (6,25\%). En este sentido destacan el CEAPAT $(42,67 \%)$, la Unidad ACCESO $(69,23 \%)$ y los Congresos TECNONEET $(94,71 \%)$; que aunque no aportan las mayores cantidades de publicaciones, la mayoría de ellas tienen relación con el vínculo entre discapacidad y tecnología.

Al analizar el recuento de registros obtenidos por cada fuente se obtiene el siguiente gráfico, donde vemos que, con diferencia, los Congresos TECNONEET son la fuente que más aporta en esta temática. 


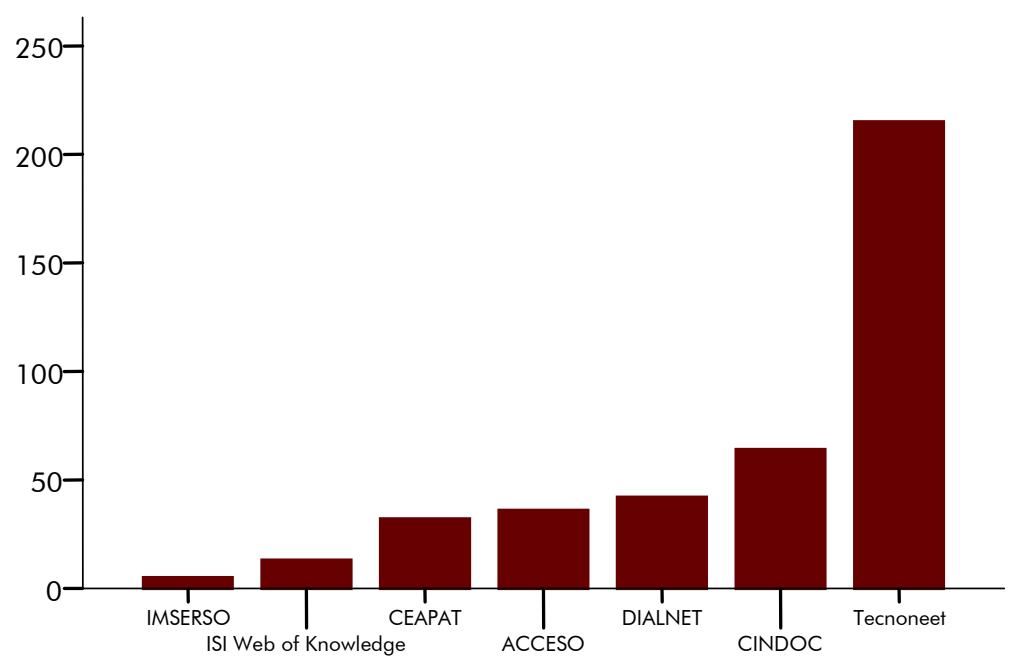

Fig. 2.2 Publicaciones referidas a discapacidad por fuentes consultadas

\subsubsection{Clasificación de la información}

\section{Clasificación del tipo de información}

Los datos encontrados fueron clasificados según el tipo de producción científica en:

- Artículo de revista

- Conferencia dictada en un Congreso

- Estudio del IMSERSO

- Libro

- Parte de libro (capítulo/s)

- Póster 


\section{Clasificación temática}

Cada publicación fue ordenada temáticamente según su título en las siguientes categorías:

Clasificación temática

Asistencia

Accesibilidad

Comunicación

Educación

Trabajo

Legislación

Rehabilitación

Experiencia
Definición

Se clasifica una publicación o proyecto como "asistencia" cuando se refiere al uso o aplicación de la tecnología para prestar socorro, favor o ayuda a las personas con discapacidad en las actividades diarias de la vida.

Se clasifica una publicación o proyecto como

"accesibilidad" cuando se refiere al uso o aplicación de la tecnología en cuanto a la facilidad con la que algo puede ser usado, visitado o accedido en general por las personas con discapacidad. En este estudio nos referimos con este término a la accesibilidad física.

Se clasifica una publicación o proyecto como

"comunicación" cuando se refiere al uso o aplicación de la tecnología en cuanto a la accesibilidad en la comunicación de las PcD, ya sea al acceso de Internet o a la interacción comunicativa en cualquier ámbito social. Se clasifica una publicación o proyecto como "educación" cuando se refiere al uso o aplicación de la tecnología en cuanto a la instrucción o enseñanza de las PcD por medio de la acción docente.

Se clasifica una publicación o proyecto como "trabajo" cuando se refiere al uso o aplicación de la tecnología en cuanto a la generación de trabajo o adaptación de trabajos para hacerlos más accesibles a las PcD.

Se clasifica una publicación o proyecto como
"legislación" cuando se refiere al análisis de las leyes relacionadas con la discapacidad y el uso o aplicación de la tecnología. Se clasifica una publicación o proyecto como "rehabilitación" cuando se refiere al uso o aplicación de la tecnología para la recuperación de una actividad o función perdida o disminuida por traumatismo o enfermedad.

Se clasifica una publicación con "experiencia" cuando es el relato de una persona con discapacidad de su experiencia en relación a la discapacidad y la tecnología.

Tabla 2.9 Definición de las categorías temáticas de clasificación.

Fuente: Elaboración propia. 


\section{Participantes}

El nombre de los autores o participantes en cada producción científica fueron unificados siguiendo el esquema [APELLIDO(S), INICIAL DEL(OS) NOMBRE(S)] para facilitar el análisis estadístico y evitar la repetición de un autor como varios diferentes.

\section{Institución}

También con las instituciones participantes en cada producción científica se realizó una homogenización. Se uniformaron los nombres de las instituciones decidiendo entre el nombre completo o la sigla, etc. Por ejemplo: las universidades son identificadas siempre siguiendo este patrón: [U. NOMBRE DE LA UNIVERSIDAD + Facultad o Departamento] que aparezcan identificados en la publicación.

Posteriormente, fueron clasificadas según las siguientes categorías:

\begin{tabular}{|c|c|c|}
\hline Tipo de institución & Subtipo & Definición \\
\hline Empresa & & $\begin{array}{l}\text { Unidad de organización dedicada a } \\
\text { actividades industriales, mercantiles o de } \\
\text { prestación de servicios con fines lucrativos. }\end{array}$ \\
\hline \multirow[t]{2}{*}{ Asociación } & $\begin{array}{l}\text { Asociación de } \\
\text { "afectados" }\end{array}$ & $\begin{array}{l}\text { Conjunto de personas que se unen para } \\
\text { lograr un fin común, lícito y determinado. En } \\
\text { este caso les une ser personas con alguna } \\
\text { discapacidad o familiares de personas con } \\
\text { discapacidad. }\end{array}$ \\
\hline & $\begin{array}{l}\text { Asociación } \\
\text { profesional }\end{array}$ & $\begin{array}{l}\text { Conjunto de personas de una misma } \\
\text { profesión que se unen para lograr un fin } \\
\text { común, lícito y determinado. }\end{array}$ \\
\hline Organismo oficial & & $\begin{array}{l}\text { Oficinas o instituciones del gobierno o que } \\
\text { dependen de algún organismo } \\
\text { gubernamental. }\end{array}$ \\
\hline Universidad & & $\begin{array}{l}\text { Institución de enseñanza superior que } \\
\text { comprende diversas facultades y que confiere } \\
\text { los grados académicos correspondientes. } \\
\text { Incluye, departamentos, centros universitarios, } \\
\text { institutos universitarios. }\end{array}$ \\
\hline
\end{tabular}




\begin{tabular}{|c|c|c|}
\hline \multirow[t]{4}{*}{ Fundación } & $\begin{array}{l}\text { Fundación } \\
\text { universitaria }\end{array}$ & $\begin{array}{l}\text { Persona jurídica sin fines de lucro cuyo patrón } \\
\text { es el rector de una universidad. }\end{array}$ \\
\hline & $\begin{array}{l}\text { Fundación } \\
\text { Empresarial }\end{array}$ & $\begin{array}{l}\text { Persona jurídica sin fines de lucro fundada por } \\
\text { una o más empresas. }\end{array}$ \\
\hline & $\begin{array}{l}\text { Fundación de } \\
\text { investigación }\end{array}$ & $\begin{array}{l}\text { Persona jurídica sin fines de lucro dedicada a } \\
\text { la investigación científica. }\end{array}$ \\
\hline & Fundación & $\begin{array}{l}\text { Persona jurídica sin fines de lucro que no es } \\
\text { una fundación universitaria, empresarial o de } \\
\text { investigación. }\end{array}$ \\
\hline Centro Educativo & & $\begin{array}{l}\text { Institución de enseñanza básica y media. } \\
\text { Incluye los centros de formación, innovación y } \\
\text { recursos educativos (CEFIRE). }\end{array}$ \\
\hline $\begin{array}{l}\text { Centro de } \\
\text { Investigación }\end{array}$ & & Organismo de investigación científica. \\
\hline $\begin{array}{l}\text { Centro de } \\
\text { Rehabilitación }\end{array}$ & & $\begin{array}{l}\text { Institución en la cual se busca la recuperación } \\
\text { de una actividad o función perdida o } \\
\text { disminuida por traumatismo o enfermedad. }\end{array}$ \\
\hline Hospital & & $\begin{array}{l}\text { Establecimiento destinado al diagnóstico y } \\
\text { tratamiento de enfermos, donde se practican } \\
\text { también la investigación y la enseñanza. }\end{array}$ \\
\hline $\begin{array}{l}\text { Profesional } \\
\text { independiente }\end{array}$ & & $\begin{array}{l}\text { Profesional que publica o dicta una } \\
\text { conferencia independiente de cualquier } \\
\text { institución. }\end{array}$ \\
\hline Persona individual & & $\begin{array}{l}\text { Persona con discapacidad o con alguna } \\
\text { relación familiar, afectiva o laboral con las } \\
\text { personas con discapacidad. }\end{array}$ \\
\hline Museo & & $\begin{array}{l}\text { Institución que guarda colecciones de objetos } \\
\text { artísticos, científicos o de otro tipo, y en } \\
\text { general de valor cultural, convenientemente } \\
\text { colocados para que sean examinados y } \\
\text { exhibidos al público. }\end{array}$ \\
\hline ONG & & Organización no gubernamental. \\
\hline
\end{tabular}

Tabla 2.10 Clasificación del tipo de institución Fuente: Elaboración propia. 


\subsubsection{Análisis de los Resultados}

Los datos obtenidos en la recopilación de la producción científica española sobre temas de discapacidad y tecnología nos clarifican el estado del sistema científico-tecnológico en esta área. Para caracterizar la situación comenzaremos revisando la evolución en el tiempo de esta producción, los diferentes tipos de manifestaciones o formas de divulgación de las investigaciones (veremos las revistas en las que se publica), las temáticas y las instituciones que participan en estos estudios, poniendo énfasis en el papel de las universidades, dado su papel protagonista en la actividad científico-tecnológica en España.

\subsubsection{Evolución en el tiempo}

Las publicaciones encontradas, que se refieren a la relación entre discapacidad y tecnología, ya sea como ayudas técnicas, utilización de las tecnologías en la educación o la adaptación de algunas tecnologías (como el ordenador) para ser accesibles a las personas con discapacidad; nos presentan un mapa de la investigación en esta área del conocimiento en los últimos años en España. 


\begin{tabular}{|c|c|c|c|}
\hline Año & Frecuencia & Porcentaje & $\begin{array}{l}\text { Porcentaje } \\
\text { Acumulado }\end{array}$ \\
\hline 1982 & 1 & 2 & 2 \\
\hline 1986 & 1 & 2 &, 5 \\
\hline 1987 & 1 & ,2 & ,7 \\
\hline 1988 & 3 & , 7 & 1,5 \\
\hline 1989 & 2 &, 5 & 2,0 \\
\hline 1991 & 1 & 2 & 2,2 \\
\hline 1993 & 1 & 2 & 2,5 \\
\hline 1994 & 3 & ,7 & 3,2 \\
\hline 1995 & 3 & , 7 & 3,9 \\
\hline 1996 & 4 & 1,0 & 4,9 \\
\hline 1997 & 8 & 2,0 & 6,9 \\
\hline 1998 & 18 & 4,4 & 11,3 \\
\hline 1999 & 14 & 3,4 & 14,7 \\
\hline 2000 & 76 & 18,7 & 33,4 \\
\hline 2001 & 20 & 4,9 & 38,3 \\
\hline 2002 & 101 & 24,8 & 63,1 \\
\hline 2003 & 26 & 6,4 & 69,5 \\
\hline 2004 & 94 & 23,1 & 92,6 \\
\hline 2005 & 19 & 4,7 & 97,3 \\
\hline $2006^{*}$ & 11 & 2,7 & 100,0 \\
\hline Total & 407 & 100,0 & \\
\hline
\end{tabular}

* hasta octubre de 2006

Tabla 2.11 Evolución temporal de la producción

Los resultados obtenidos son esperanzadores, ya que la producción española referida a la relación entre discapacidad y tecnología presenta un claro aumento en cantidad de publicaciones y presentaciones en congresos o conferencias en la última década. 
En 1982 se encuentra sólo una publicación relacionada con el tema (parte de un libro) titulada "Ayudas técnicas para los discapacitados del lenguaje por causas neuromotrices", fruto de una exposición en el encuentro Los trastornos de la comunicación en el niño: Io Simposio de Logopedia. Desde ese momento se observa un crecimiento cuantitativo de la producción científica española sobre este tema.

Es notorio el fuerte incremento de la producción en los años 2000, 2002 y 2004 (Fig. 2). La razón de este aumento está dada por la creación en el año 2000, por la Consejería de Educación y Cultura de la Región de Murcia, España, del Foro Tecnoneet (http://www.tecnoneet.org/), un espacio para el intercambio de experiencias, metodologías y conocimientos sobre los avances tecnológicos y estrategias de intervención que se generan en el ámbito de las Tecnologías de la Información y Comunicación (TIC) y las necesidades educativas especiales. De este foro surgen los Congresos Nacionales Tecnoneet, encuentros que se celebran en la ciudad de Murcia cada dos años desde el $2000 .^{16}$

${ }^{16}$ El Congreso Tecnoneet-ciiee 2006 se celebró los días 28, 29 y 30 de septiembre de 2006, pero a octubre del mismo año no habían sido publicadas las actas. Por esta razón no está incluido en la investigación. 


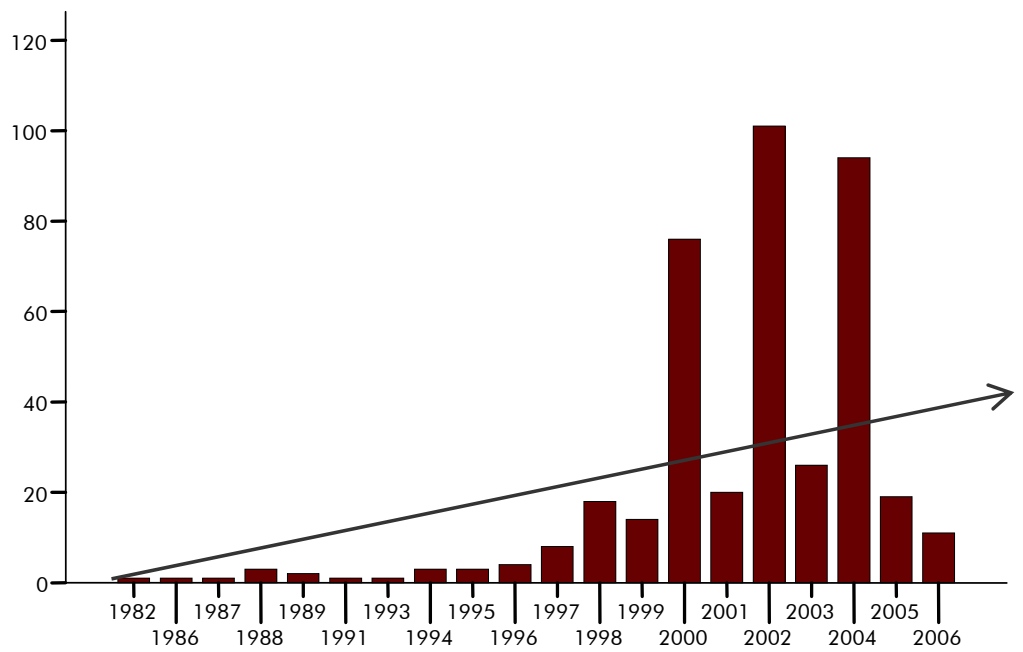

Fig. 2.3 Evolución temporal de la producción

Lo importante es que, al margen de la concentración cuantitativa que se presenta en estos años, es posible observar un claro aumento del número de publicaciones referidas a la relación entre discapacidad y tecnología. Se manifiesta así una mayor preocupación por parte de los investigadores por estudiar el tema.

\subsubsection{Tipo de producción}

Gracias a la realización de los Congresos Tecnoneet el mayor número de publicaciones son conferencias en congreso, que representan un poco más de la mitad del total de lo producido en el período analizado $(55,8 \%)$. En segundo lugar, con un $26 \%$, están los artículos de revista, seguidos por los libros y parte de libro que en conjunto representan un $15 \%$ del total de publicaciones. 


\begin{tabular}{lccc}
\hline Tipo & Frecuencia & Porcentaje & $\begin{array}{c}\text { Porcentaje } \\
\text { Acumulado }\end{array}$ \\
\hline Artículo de revista & 106 & 26,0 & 26,0 \\
Conferencia Congreso & 227 & 55,8 & 81,8 \\
Estudio IMSERSO & 5 & 1,2 & 83,0 \\
Libro & 46 & 11,3 & 94,3 \\
Parte de libro & 15 & 3,7 & 98,0 \\
Póster & 8 & 2,0 & 100,0 \\
Total & 407 & 100,0 & \\
\hline
\end{tabular}

Tabla 2.12 Tipo de producción

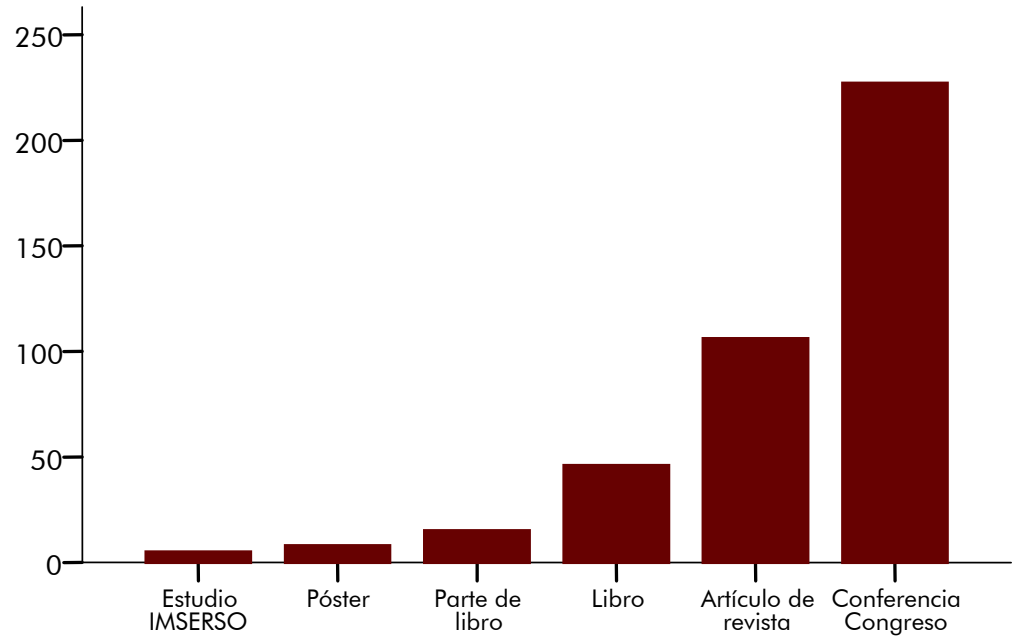

Fig. 2.4 Tipo de producción 


\section{Revistas}

La revista en la que aparece mayor cantidad de artículos referidos a discapacidad y tecnología es "Integración. Revista sobre Ceguera y Deficiencia Visual". Le siguen "Comunicación y Pedagogía", "Revista de biomecánica", "Siglo Cero", y "Educar en el 2000". Estas publicaciones concentran entre 11 y 4 artículos cada una en el periodo analizado. Las siguientes revistas no superan los tres títulos y el $37,8 \%$ sólo tiene una publicación de este tema.

Integración. Revista sobre Ceguera y Deficiencia

Visual

Comunicación y Pedagogía

Revista de biomecánica

8

7,5

Siglo Cero

$6 \quad 5,7$

Educar en el 2000

$5 \quad 4,7$

Boletín Factores Humanos

4

Novática

$3 \quad 2,8$

Primeras Noticias. Comunicación y Pedagogía

Revista General de Información y Documentación

3

AHCIET. Revista de telecomunicaciones

Boletín del Real Patronato

2

Comunicar. Revista de Medios de Comunicación y Educación

Educación y Biblioteca. Revista Mensual de

Documentación y Recursos Didácticos

Informació Psicològica

Mundo electrónico

Red digital: Revista de Tecnologías de la

Información y Comunicación Educativas

Rehabilitación: Revista de la Sociedad Española de

Rehabilitación y Medicina Física

$2-1,9$

Telos: Cuadernos de comunicación, tecnología y sociedad

2

Al Communications

American Journal of Epidemiology

Anales de ingeniería mecánica

2

Anuario de Psicología

Apuntes de Psicología

Autonomous Robots

Boletín económico de ICE, Información Comercial

2 


\begin{tabular}{|c|c|c|}
\hline \multicolumn{3}{|l|}{ Española } \\
\hline Comunicaciones de telefónica I+D & 1 & 0,9 \\
\hline Cuadernos de Pedagogía & 1 & 0,9 \\
\hline Documentación de las Ciencias de la Información & 1 & 0,9 \\
\hline $\begin{array}{l}\text { Documentos de trabajo ( Laboratorio de } \\
\text { alternativas ) }\end{array}$ & 1 & 0,9 \\
\hline $\begin{array}{l}\text { Educación Social. Revista de Intervención } \\
\text { Socioeducativa }\end{array}$ & 1 & 0,9 \\
\hline Edutec: Revista electrónica de tecnología educativa & 1 & 0,9 \\
\hline Encuentros en Psicología Social & 1 & 0,9 \\
\hline FIAPAS & 1 & 0,9 \\
\hline Fisioterapia & 1 & 0,9 \\
\hline Geriátrika. Revista Iberolatinoamericana de & 1 & 0,9 \\
\hline $\begin{array}{l}\text { Geriatría y Gerontología } \\
\text { Innovación Educativa }\end{array}$ & 1 & 0,9 \\
\hline Journal of Intellectual Disability Research & 1 & 0,9 \\
\hline Journal of Learning Disabilities & 1 & 0,9 \\
\hline $\begin{array}{l}\text { Journal of Rehabilitation Research and } \\
\text { Development }\end{array}$ & 1 & 0,9 \\
\hline M.I. Montajes e instalaciones & 1 & 0,9 \\
\hline Minusval & 1 & 0,9 \\
\hline Pixel-Bit: Revista de medios y educación & 1 & 0,9 \\
\hline Quaderns Digitals & 1 & 0,9 \\
\hline Quinesia. Revista de Educación Especial & 1 & 0,9 \\
\hline Revista de Educación (Madrid) & 1 & 0,9 \\
\hline Revista de Enseñanza Universitaria & 1 & 0,9 \\
\hline Revista de logopedia, foniatría y audiología & 1 & 0,9 \\
\hline Revista de Logopedia, Foniatría y Audiología & 1 & 0,9 \\
\hline Revista del Instituto de Estudios Económicos & 1 & 0,9 \\
\hline Revista DIM: Didáctica, Innovación y Multimedia & 1 & 0,9 \\
\hline Revista electrónica de terapia ocupacional Galicia & 1 & 0,9 \\
\hline Revista Española de Documentación Científica & 1 & 09 \\
\hline Revista Española de Geriatría y Gerontología & 1 & 0,9 \\
\hline Revista española de salud pública & 1 & 0,9 \\
\hline Revista Rol de Enfermería & 1 & 0,9 \\
\hline Safety Science & 1 & 0,9 \\
\hline Trabajo social y salud & 1 & 0,9 \\
\hline Travail Humain & 1 & 09 \\
\hline $\begin{array}{l}\text { Universitas Tarraconensis. Revista de Ciències de } \\
\text { l'Educació }\end{array}$ & 1 & 0,9 \\
\hline XXI. Revista de Educación & 1 & 0,9 \\
\hline Total & 106 & 100,0 \\
\hline
\end{tabular}

Tabla 2.13 Revistas donde se publica sobre discapacidad y tecnología 


\subsubsection{Temas}

Las publicaciones recogidas en esta investigación han podido ser clasificadas, como hemos mencionado anteriormente, en 8 temáticas diferentes: educación, comunicación, asistencia, rehabilitación, accesibilidad, trabajo, experiencia y legislación.

Los tres grandes temas, que abarcan en conjunto el 76,6\% del total de los títulos, son educación, comunicación y asistencia. El 34,9\% de los títulos analizados se refieren a la educación, es decir, al uso o aplicación de la tecnología en la instrucción o enseñanza de las personas con discapacidad por medio de la acción docente. El 21,6\%, a la accesibilidad en la comunicación de las personas con discapacidad, ya sea al acceso de Internet o a la interacción comunicativa en cualquier ámbito social. Finalmente, cerca del $20 \%$ de las publicaciones tienen que ver con la asistencia, con el uso o aplicación de la tecnología para prestar socorro, favor o ayuda a las personas con discapacidad en las actividades diarias de la vida.

\begin{tabular}{lcc}
\hline \multicolumn{1}{c}{ Temas } & Frecuencia & Porcentaje \\
\hline Educación & 142 & 34,9 \\
Comunicación & 88 & 21,6 \\
Asistencia & 82 & 20,1 \\
Rehabilitación & 32 & 7,9 \\
Accesibilidad & 29 & 7,1 \\
Trabajo & 21 & 5,2 \\
Experiencia & 8 & 2,0 \\
Legislación & 5 & 1,2 \\
Total & 407 & 100,0 \\
\hline
\end{tabular}

Tabla 2.14 Producción científica por temas 
Los temas de rehabilitación y accesibilidad son los siguientes más tratados, con casi un $8 \%$ y un 7\%, respectivamente. Hemos diferenciado en este estudio la accesibilidad física (a lo que nos referimos con el término accesibilidad) y la accesibilidad a los medios de comunicación (a la que hemos incluido en la categoría comunicación), siendo Internet y el ordenador los elementos más destacados en este último punto.

En el tema de la rehabilitación, es decir, cuando se refiere al uso o aplicación de la tecnología para la recuperación de una actividad o función perdida o disminuida por traumatismo o enfermedad, destacan las aportaciones a congresos, seguidas por los artículos en revistas.

Por su parte, cuando se habla del uso o aplicación de la tecnología en cuanto a la facilidad con la que algo puede ser usado, visitado o accedido por las personas con discapacidad, hay mayor número de publicaciones como libros y artículos de revistas que de conferencias en congresos.

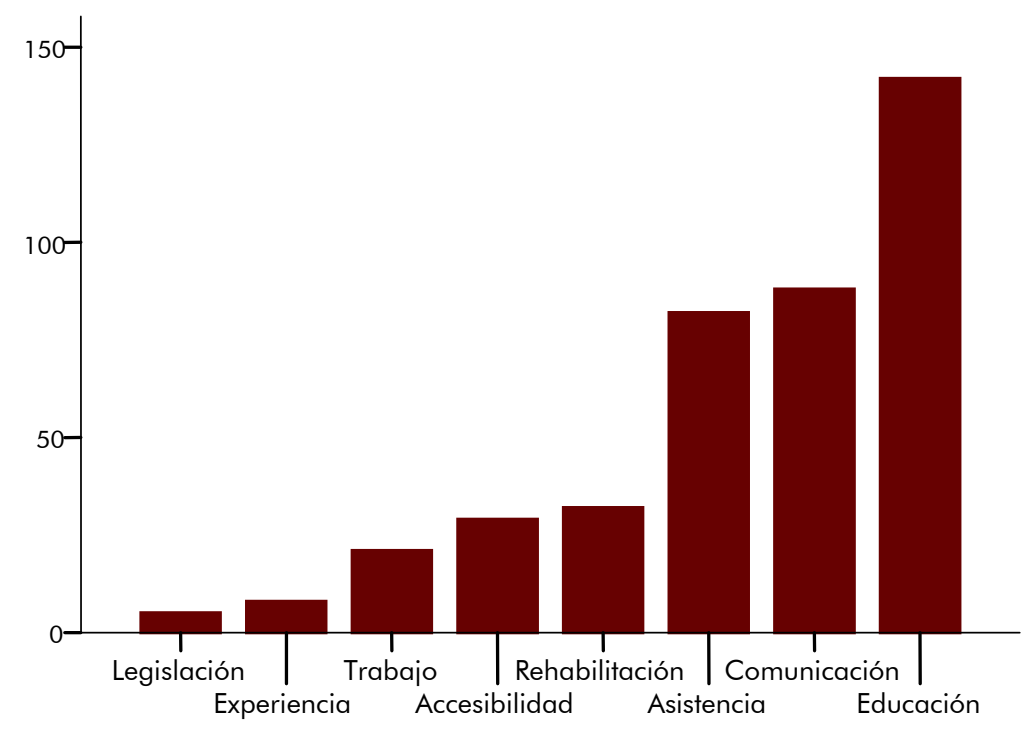

Fig. 2.5 Producción científica por temas 
Los temas relacionados con la tecnología en cuanto a la generación de trabajo o adaptación de trabajos para hacerlos más accesibles, son en su mayoría tratados en artículos de revistas.

Aunque sea en un pequeño porcentaje, es interesante destacar la presencia de relatos de personas con discapacidad o de personas cercanas a esta realidad sobre su experiencia en relación a la discapacidad y la tecnología. Son sólo 8 publicaciones (un $2 \%$ del total), pero representan una característica de participación directa de las personas con discapacidad; no sólo como receptores de las tecnologías, sino como agentes activos del sistema, entregando información práctica del uso y adaptación de la tecnología, al poder criticar, positiva o negativamente, con total conocimiento de causa la acción de la tecnología en sus vidas.

La escasa presencia de publicaciones referidas a la legislación $(1,2 \%)$ no debe leerse como una falta de normativas en este tema. En la recopilación de los datos no se han considerado las leyes, decretos, etc., que regulan en la actualidad, sino sólo aquellos artículos que reflexionen o realicen un análisis de las leyes relacionadas con la discapacidad y el uso o aplicación de la tecnología.

\subsubsection{Instituciones}

Las instituciones con mayor presencia en las publicaciones analizadas son las educacionales: la Universidad, con un 42,6\%, y los Centros Educativos de nivel medio, con un 17,1\% del total. Destaca además la presencia de Organismos oficiales (15,7\%) y las Empresas (10,2\%). También tienen una 
importante participación, aunque en considerable menor medida, las Asociaciones de afectados.

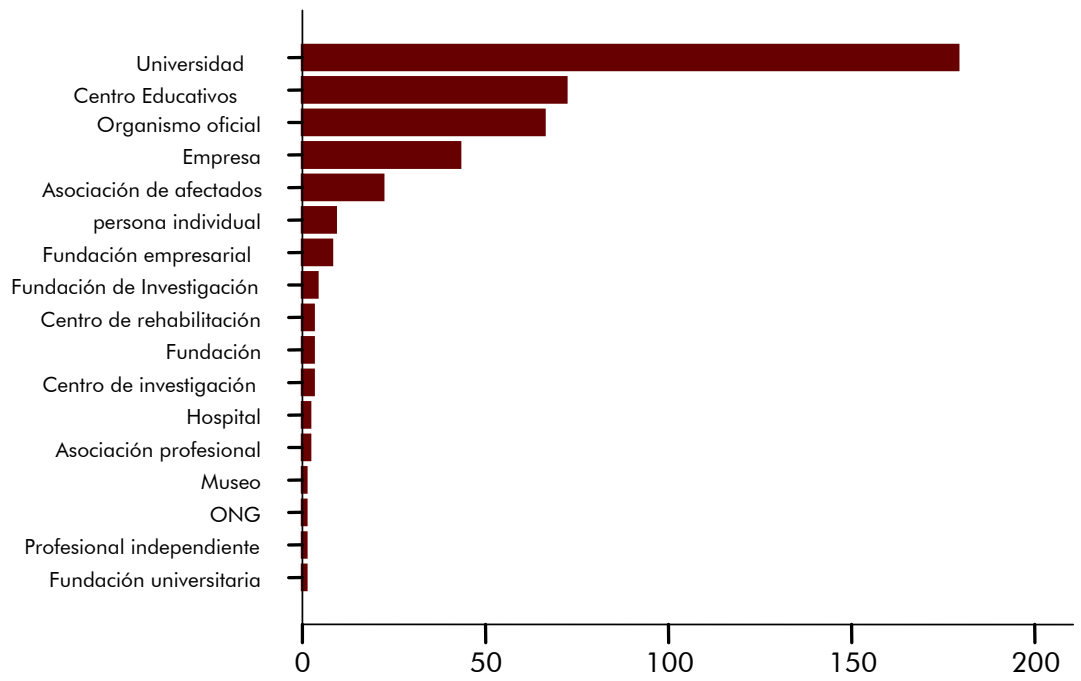

Fig. 2.6 Instituciones con presencia en las publicaciones

La gran cantidad de centros educativos con los que están relacionados los autores de estas publicaciones revela una gran preocupación por el tema de la relación entre tecnología y discapacidad por parte de los educadores, quienes ven en las tecnologías una ayuda en sus tareas docentes hacia niños con necesidades educativas especiales. La realización bianual de los Congresos Tecnoneet en Murcia favorece este intercambio de información, experiencias e innovaciones a nivel educativo. Por esta razón, sin duda, predomina la participación de centros educacionales de esta comunidad autónoma.

Resalta, nuevamente, la presencia de personas con discapacidad o relacionadas con ella (madres de discapacitados, por ejemplo) que a nivel individual participan en el sistema, ya sea presentándose en congresos o escribiendo libros. 


\begin{tabular}{lccc}
\hline \multicolumn{1}{c}{ Tipo } & Frecuencia & Porcentaje & $\begin{array}{c}\text { Porcentaje } \\
\text { Acumulado }\end{array}$ \\
\hline Asociación de afectados & 22 & 5,2 & 5,2 \\
Asociación profesional & 2 &, 5 & 5,7 \\
Centro de investigación & 3 &, 7 & 6,4 \\
Centro de rehabilitación & 3 &, 7 & 7,1 \\
Centro Educativo & 72 & 17,1 & 24,3 \\
Empresa & 43 & 10,2 & 34,5 \\
Fundación & 3 &, 7 & 35,2 \\
Fundación de Investigación & 4 & 1,0 & 36,2 \\
Fundación empresarial & 8 & 1,9 & 38,1 \\
Fundación universitaria & 1 &, 2 & 38,3 \\
Hospital & 2 &, 5 & 38,8 \\
Museo & 1 &, 2 & 39,0 \\
ONG & 1 &, 2 & 39,3 \\
Organismo oficial & 66 & 15,7 & 55,0 \\
Persona individual & 9 & 2,1 & 57,1 \\
Profesional independiente & 1 &, 2 & 57,4 \\
Universidad & 179 & 42,6 & 100,0 \\
Total & 420 & 100,0 & \\
\hline & & & \\
\hline
\end{tabular}

Tabla 2.15 Tipo de instituciones

Que la Universidad sea la institución con la que se relacionan el mayor número de autores de las publicaciones analizadas, confirma el importante papel de estas entidades en el sistema de generación y difusión del conocimiento científico en la sociedad española.

A la hora de presentar resultados de investigaciones o realizar publicaciones, la mayor cantidad de autores pertenecen, dentro de la universidad, a grupos de investigación. Un alto porcentaje se identifica 
solamente con el nombre de la Universidad (26,3\%). Posteriormente a nivel de Departamento (24,6\%), Instituto Universitario $(9,5 \%)$ y Facultad (7,3\%). Por último, los Laboratorios, Centros tecnológicos o Servicio de Informática aparecen en conjunto sólo en un 3,4\% de los casos.

Dentro de los grupos de investigación el papel más relevante lo tiene la Unidad de Investigación ACCESO del Departamento de Psicología Evolutiva y de la Educación de la Universidad de Valencia. Este grupo, creado en 1994, trabaja en investigación, desarrollo y aplicación sobre temas en los que se combinan la discapacidad, la tecnología y la educación. Sus líneas de investigación son Diseño para Todos de Entornos de Aprendizaje, e_learning y accesibilidad a la red, Evaluación psicoeducativa, Tecnologías de ayuda e Integración educativa y sociolaboral de personas con minusvalías.

Otros grupos presentes son el Grupo de Investigación "Electrónica Industrial y Médica" de la Universidad Politécnica de Cartagena, el Grupo de Investigación de Tecnología Educativa de la Universidad de Murcia y el Grupo de Investigación en Gerontología de la Universidad de A Coruña.

Los Departamentos que trabajan en este campo son los relacionados con educación, didáctica, psicología, comunicación, ingeniería e informática, principalmente.

Gracias a la acción del Grupo de Investigación ACCESO de la Universidad de Valencia, esta es la institución que representa el mayor porcentaje de participación en la producción científica relacionada con discapacidad y tecnología. Por otra parte, el Instituto de Biomecánica de Valencia, asociado a la Universidad Politécnica de Valencia, contribuye también a que sea esta ciudad española un importante punto generador de conocimientos científicos en esta área. 


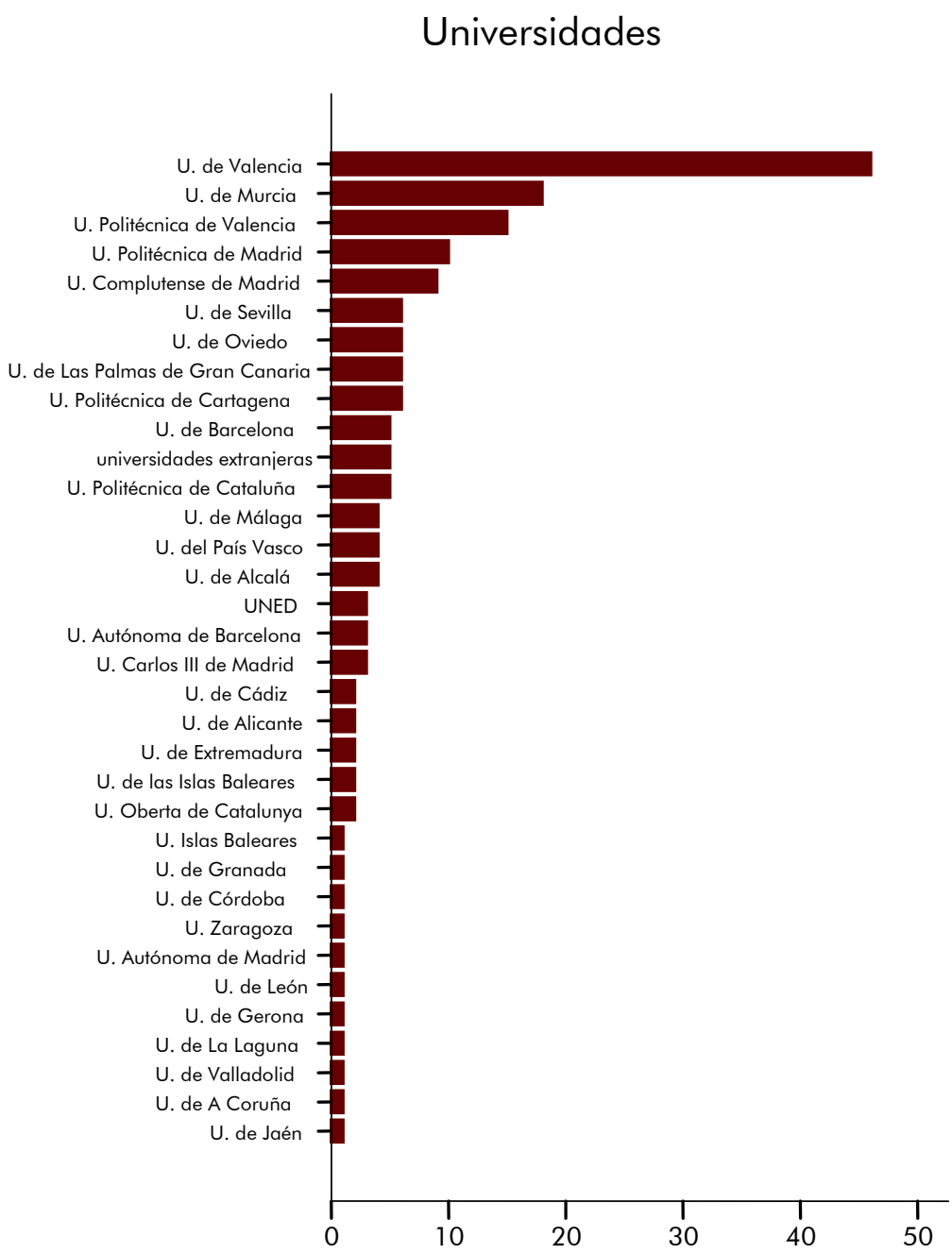

Fig. 2.7 Producción científica por universidades

La presencia de la Universidad de Murcia en el segundo lugar de la tabla tiene directa relación con la realización de los Congresos Tecnoneet que impulsan la investigación sobre estos temas en esa región. 


\begin{tabular}{lccc}
\hline Universidades & Frecuencia & Porcentaje & Porcentaje \\
Acumulado
\end{tabular}

Tabla 2.16 Producción científica por universidades

En la Tabla 2.16 se aprecia el ranking de la presencia de las universidades en las publicaciones referidas a discapacidad y tecnología recogidas en esta tesis. 


\section{Organismos oficiales}

Como se ha señalado, los organismos oficiales son también instituciones con una alta tasa de participación en la producción en el tema. Los organismos regionales como las consejerías de educación son los entes más activos, con un $45,5 \%$, seguidos por los nacionales que representan el $43,9 \%$ del total de entidades oficiales.

A nivel nacional, están presentes el Centro Estatal de Autonomía Personal y Ayudas Técnicas (CEAPAT), el Consejo Superior de Investigaciones Científicas (CSIC), el Instituto de Mayores y Servicios Sociales (IMSERSO), el Real Patronato de Discapacidad y el Ministerio de Fomento.

Los organismos regionales y nacionales constituyen casi la totalidad de las instituciones oficiales presentes en la documentación analizada. Las entidades extranjeras que han sido consideradas por estar en colaboración con alguna institución española son la Agencia Europea para el Desarrollo de la Educación Especial, una universidad de Roma (Italia) y la Comisión Central de Coordinación para la Promoción de la Accesibilidad de los Países Bajos. 
Capítulo 3. Conclusiones 
- El concepto de cultura ha evolucionado progresivamente de designar labores agrícolas a denominar a todas aquellas actividades relacionadas con el ocio y la diversión, principalmente manifestaciones artísticas. Su evolución, sin embargo, no ha terminado. Las discusiones sobre la brecha entre "cultura" y ciencia han llevado a varios autores a eliminar esta sima y a englobar dentro de la cultura a toda aquella información transmitida por aprendizaje social, incluido, por lo tanto, el conocimiento científico-técnico.

- El modelo desarrollado por Quintanilla, aporta un valioso marco que permite estudiar y comprender el conocimiento de la sociedad, particularmente de su cultura científico-tecnológica. La caracterización de la información representacional, práctica y valorativa en relación a la ciencia y la tecnología que maneja la población - o una parte de ella - es un elemento fundamental en el contexto de la comunicación pública de la ciencia y en las tareas de divulgación.

- En cuanto a la situación de las personas con discapacidad en España vemos una clara preocupación por parte de las administraciones públicas por ofrecer un marco que otorgue garantías legales a este colectivo. Se busca también, fomentar la investigación y desarrollo (I+D) y la protección de la igualdad de oportunidades, mediante la creación de normativas que aseguren la no discriminación en procesos, diseños y desarrollos de tecnologías, productos, servicios y bienes.

- En la línea de la protección de las garantías personales, la Ley de Promoción a la Autonomía Personal y Atención a las Personas Dependientes, aprobada a fines del año 2006, sobresale junto con el Servicio de Teleasistencia, el uso de las tecnologías de la 
comunicación y de la información ante situaciones de emergencia, inseguridad, soledad o aislamiento. Se busca fomentar el empleo de ayudas técnicas a través de subvenciones económicas para su compra y para facilitar la accesibilidad y adaptaciones en el hogar.

- Vemos que hay una intención de mayor compromiso hacia las investigaciones en áreas relacionadas con la dependencia en los planes de I+D+I. Hasta ahora esto ha sido el punto más débil. En el vigente Plan Nacional de Investigación Científica, Desarrollo e Innovación Tecnológica 2004-2007, sólo hay un tema, dentro de los aspectos prioritarios, que se relacione directamente con las personas discapacitadas. Si bien dentro de cuatro Programas Nacionales es posible encontrar líneas de investigación vinculadas con el asunto.

- La falta de investigación se refleja en la producción científica nacional sobre discapacidad y tecnología. Los estudios científicos, las publicaciones y la divulgación de sus resultados son escasos. De las investigaciones en discapacidad, sólo el $10,84 \%$ se refiere a la tecnología.

- A pesar del pequeño volumen de producción científica española en este ámbito, los resultados son esperanzadores, ya que en la última década el número de publicaciones y presentaciones en congresos o conferencias ha ido aumentando lenta, pero constantemente.

- En el ámbito educativo destaca la presencia de personas con discapacidad como agentes activos del sistema, entregando información práctica del uso y adaptación de la tecnología. Cuantitativamente su número no es significativo, representan sólo un $2 \%$ del total, pero su presencia da indicios de su iniciativa para participar en el sistema científico-tecnológico. 


\section{PARTE II}

Aplicación de un modelo de cultura científicotecnológica en las personas con discapacidad 
Capítulo 4. El análisis de contenido: una herramienta científica de investigación 


\section{1 Introducción}

El análisis de contenido es una técnica de investigación, empleada principalmente en las Ciencias Sociales, cuyo éxito dependerá de la creatividad y experiencia del investigador, de la fiabilidad y validez de su diseño y de la corrección de su aplicación.

Bernard Berelson (1952:18), uno de los padres de este método, afirmaba que dicha técnica servía para describir de forma objetiva, sistemática y cuantitativa el contenido de cualquier tipo de comunicación, ya sea ésta formal o informal: "content analysis is a research technique for the objetive, systematic, and quantitative description of the manifest content of communication".

Para Lawrence Bardin (1986:7) el análisis de contenido "es un conjunto de instrumentos metodológicos, cada vez más perfectos y en constante mejora, aplicados a 'discursos' (contenidos y continentes) extremadamente diversificados".

Klaus Krippendorff amplía los alcances epistemológicos y metodológicos en su famosa obra Content Analysis, llegando a calificarlo como una herramienta científica (scientific too).

Content analysis is a research technique for making replicable and valid inferences from texts (or other meaningful matter) to the contexts of their use. As a technique, content analysis involves specialized procedures. It is learnable and divorceable from the personal authority of the researcher. As a research technique, content analysis provides new insights, increases a researcher's understanding of particular phenomena, or informs practical actions. Content analysis is a scientific tool. (Krippendorff 2004:18) 
Los estudios en los que esta técnica puede ser útil son numerosos, pero destacan los que intentan analizar los procesos de comunicación; ya sean verbales, textuales, icónicos y/o sonoros. No es de extrañar que en la actualidad el incremento de los análisis de contenido sea significativo debido, sin lugar a dudas, a las nuevas tecnologías de la información y la comunicación.

$\mathrm{Si}$ bien es cierto que no existe un consenso sobre si estos análisis se encuadran dentro de una metodología cuantitativa o cualitativa, nosotros no entraremos en esta polémica ya que realizamos tanto recuento de frecuencias y datos como un análisis de "grano fino". Nuestro objetivo es validar y contrastar las hipótesis intentando por todos los medios evitar tanto la recopilación sin sentido de datos como la especulación arbitraria.

\subsection{Fases del análisis de contenido}

Aunque el esquema que se presenta a continuación organiza las fases cronológicamente según las tareas realizadas en esta investigación, es preciso advertir que el proceso no es lineal sino recursivo, que obliga a la vuelta continua sobre algunos pasos con el fin de afinar la metodología.

Basándonos en Bardin (1977) y Rodríguez, G., Gil, J. \& García, E. (1996) señalamos las siguientes fases del proceso:

1) Preanálisis: fase preparatoria en la cual uno entra en contacto con los datos, reflexiona sobre ellos y selecciona la información relevante para el análisis.

2) Diseño: se diseña el método de análisis, detallando el proceso de categorización y codificación de los textos estudiados. 
3) Recopilatoria: recogida de los datos en las diferentes bases y tratamiento primario de los resultados.

4) Analítica-experimental: tratamiento específico de los textos aplicando las categorías definidas. En esta etapa se produce un proceso de complementación y redefinición de las categorías y del método.

5) Interpretativa: se verifica la validez de los resultados estadísticos y cualitativos y se sintetizan y seleccionan para su interpretación final. Se establecen conclusiones basadas en los datos obtenidos y se plantean nuevas hipótesis para posibles nuevas investigaciones.

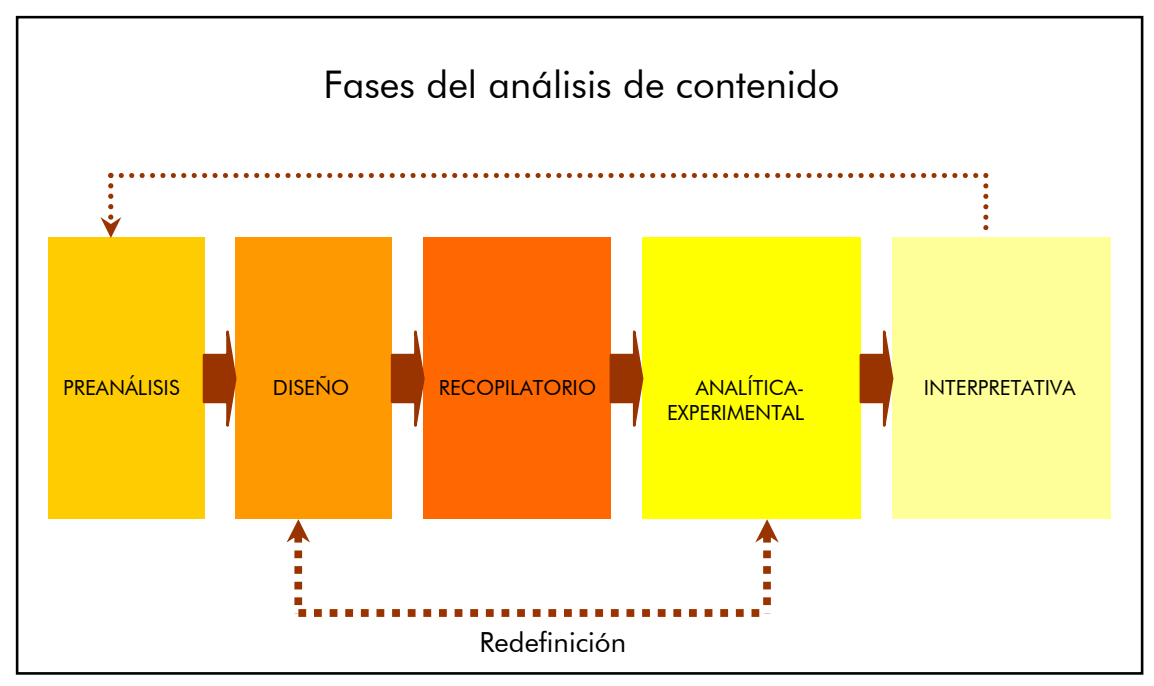

Fig. 4.1 Fases del análisis de contenido 
Parte II. Aplicación de un modelo de cultura científico-tecnológica en las personas con discapacidad

4.3 Árbol temático de las categorías de los análisis de contenido

A continuación se presenta el "árbol de categorías" correspondiente a los análisis de contenido realizados en esta investigación. La explicación y definición detallada de cada una de las categorías se expondrá debidamente en el desarrollo de la metodología aplicada en los análisis.

4.3.1 Categorías comunes para el análisis de la revista Minusval y los periódicos

\section{REVISTA/PERIÓDICO}

CATEGORÍAS GENERALES

CULTURA CIENTÍFICA INTRÍNSECA

Representacional

Práctica

Valorativa

EXTRÍNSECA

Representacional

Práctica

Valorativa

CULTURA TECNOLÓGICA

INTRÍNSECA

Representacional

Práctica

Valorativa

EXTRÍNSECA

Representacional

Práctica

Valorativa

CATEGORÍAS ESPECIIFICAS

IMÁGENES Y VALORES

POSITIVOS

Facilitar

Accesibilidad

Integración

Apoyo

Independencia

Avance

Mejora 
Útil

Sencillez

Necesario

Oportunidad

Calidad de Vida

Comunicación

Beneficio

Esperanza

Seguridad

Ventaja

Eficacia

Moderno

Comodidad

Igualdad

Adecuación

Barato

Cambio

Solución

Versatilidad

Calidad

Importancia

Rapidez

Confianza

Interesante

Bienestar

Eficiencia

Inteligencia

Positivo

Favorecer

Potencia

Precisión

Innovación

Lúdico

Natural

Respeto

Aceptación

Alivio

Cercanía

Efectividad

Equilibrio

Fiabilidad

Tranquilidad

Validez

Variedad

\section{NEGATIVOS}

Exclusión

Brecha

Dificultad

Problema

Inadecuado 
Parte II. Aplicación de un modelo de cultura científico-tecnológica en las personas con discapacidad

Caro

Ineficiencia

Rechazo

Riesgo

Incompleto

Dependencia

Complejidad

Inseguridad

Nocivo

Obsoleto

Estresante

Desigualdad

Desventaja

Exceso

Incompatibilidad

Injusto

Insuficiencia

Miedo

Molestia

Sedentarismo

DESEADOS

Accesibilidad

Brindar Facilidades

Sencillez

Igualdad

Adecuación

Independencia

Seguridad

Integración

Agradable

Asequible

Barato

Comodidad

Compatibilidad

Útil

Eficiencia

Confianza

Inteligencia

Mejora

Natural

Versatilidad 
4.3.2 Categorías específicas para el análisis de los diarios (El País y El Mundo)

\section{PERIÓDICO}

\section{AÑO}

CATEGORÍAS ESPECÍFICAS

PESO

TODA

PARTE

PÁRRAFO

IMAGEN

RECEPTOR

USUARIO

GENERADOR

SR 
Capítulo 5. Análisis de la revista Minusval. La cultura científico-tecnológica 


\subsection{La Revista Minusval}

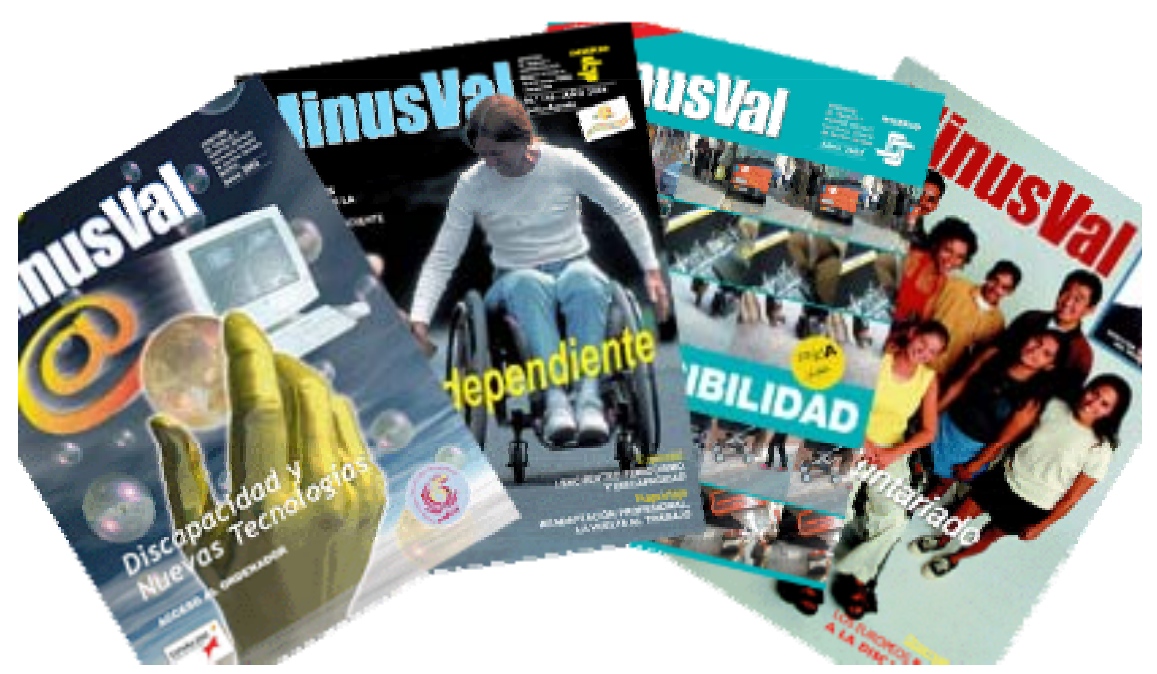

La cultura científica y tecnológica de un grupo social está compuesta por información representacional sobre la ciencia y la tecnología, basados o no en conocimientos científicos reales; información práctica e información valorativa. Para conocer la cultura científica y tecnológica que reciben las personas con discapacidad, se ha realizado un análisis de contenido a la Revista Minusval, una publicación especializada bimensual dirigida a personas con discapacidad, profesionales y entidades que trabajan en favor de este colectivo.

Actualmente en España existe un gran número de publicaciones especializadas en diversos aspectos de las diferentes discapacidades, por lo menos hay 12 boletines y 32 revistas, con regularidades periódicas desde cada dos meses hasta las que se publican sin un criterio temporal claro. La gran mayoría se especializan en un público objetivo específico dentro de las personas con discapacidad y con una temática concreta 
Parte II. Aplicación de un modelo de cultura científico-tecnológica en las personas con discapacidad

como el Síndrome de Down, la discapacidad visual, auditiva o física, el autismo, etc.

La Revista Minusval es una publicación especializada en temas de discapacidad, pero no se limita a un subtema específico, razón que ha permitido seleccionarla para ser objeto de este análisis. Tiene una tirada de 35.000 ejemplares a color y se distribuye en todas las Comunidades Autónomas españolas, además de Ceuta y Melilla. Tiene como objetivos informar sobre la problemática de la Discapacidad, tanto psíquica, como física y sensorial, y ser canal de documentación profesionalizada en este ámbito. Su publicación es bimestral y gracias a las bases de datos del Servicio de Información sobre Discapacidad, SID, de la Universidad de Salamanca, hemos podido contar con sus ejemplares en formato PDF desde el número 130 (septiembre-octubre de 2001) hasta el número 158 (julio-agosto de 2006), un total de 37 revistas.

\subsection{Objetivos del análisis}

El análisis de contenido a la revista Minusval se ha centrado en tres objetivos fundamentales:

a) Identificar la información representacional, práctica y valorativa incorporada y no incorporada de ciencia y tecnología presente en los textos de la revista Minusval.

b) Identificar los elementos de la ciencia y la tecnología que se relacionen con las personas con discapacidad; y analizar la relación que se establece.

c) Identificar las imágenes de la ciencia y la tecnología presentes en los textos de la revista Minusval. 


\subsection{Metodología}

Para identificar la cultura científica y tecnológica presente en los textos se han utilizado algunas de las palabras claves relacionadas con ciencia y tecnología empleadas en estudios anteriores ${ }^{17}$, centrándonos exclusivamente en conceptos amplios y generales.

\begin{tabular}{|c|c|}
\hline Concepto & Comodines de búsqueda \\
\hline CIENCIA & cienci* $^{*}$ científic*$^{*} \mid$ cientific*$^{*}$ \\
\hline TECNOLOGÍA & tecnolog*|tecnólog*|tecnológ*| técnica*| \\
\hline
\end{tabular}

Al aplicar los comodines de búsqueda al texto se han encontrado 2.950 referencias en total: 481 a Ciencia y 2.469 a Tecnología. Al tener identificados los párrafos en los que aparecen tales términos se ha realizado un análisis manual de los textos seleccionados para identificar el tipo de información transmitida.

A través de este análisis de "grano fino" se ha determinado el tipo de cultura tecnológica transmitido, codificando la información publicada en la revista en las categorías que vemos a continuación (Tabla 5.2).

17 "Análisis de la Cultura Científica, Tecnológica y de Innovación en la E.S.O", 2007, financiado por la Fundación Cotec (en vías de publicación), es uno de los estudios que utilizan estos conceptos para analizar la cultura científico-tecnológica en los libros de texto. 
Parte II. Aplicación de un modelo de cultura científico-tecnológica en las personas con discapacidad

\begin{tabular}{llll}
\hline Cultura Científica & Representacional & Intrínseca & 01CRI \\
\cline { 3 - 4 } & & Extrínseca & 02CRE \\
\cline { 2 - 4 } & Práctica & Intrínseca & $03 \mathrm{CPI}$ \\
\cline { 3 - 4 } & & Extrínseca & $04 \mathrm{CPE}$ \\
\cline { 2 - 4 } & Valorativa & Intrínseca & $05 \mathrm{CVI}$ \\
\cline { 3 - 4 } & & Extrínseca & $06 \mathrm{CVE}$ \\
\hline Cultura Tecnológica & Representacional & Intrínseca & $07 \mathrm{TRI}$ \\
\cline { 3 - 4 } & & Extrínseca & $08 \mathrm{TRE}$ \\
\cline { 2 - 4 } & Práctica & Intrínseca & $09 \mathrm{TPI}$ \\
\cline { 2 - 4 } & & Extrínseca & $10 \mathrm{TPE}$ \\
\cline { 2 - 4 } & & Intrínseca & $11 \mathrm{TVI}$ \\
\cline { 2 - 4 } & Valorativa & Extrínseca & $12 \mathrm{TVE}$
\end{tabular}

Tabla 5.2 Abreviaturas de los tipos de cultura científico-tecnológica

Posteriormente, para cumplir el objetivo de identificar los diferentes tipos de tecnologías presentes en los textos y la relación que se establece entre esas tecnologías y las personas con discapacidad, se ha realizado una selección automática de los párrafos en los que aparecen términos relacionados con la técnica y la tecnología.

Este proceso de selección automática se ha llevado a cabo, primeramente con la obtención de una lista de palabras claves, aplicando el programa WordSmith a los siguientes documentos:

1. COTEC, 1997. Documentos COTEC sobre Necesidades Tecnológicas. Sector de la Rehabilitación.

2. IBV, 2005. Tecnologías al servicio de las personas con discapacidad y las personas mayores. Cuadernos de Biomecánica. 
3. CERMI, 2003. Libro Blanco de I+D+I al servicio de las personas con discapacidad y las personas mayores.

De las 7.504 palabras analizadas por el programa, con frecuencias que oscilan entre 540 y 1 , se eligieron manualmente términos referidos a técnicas o a artefactos resultantes de una técnica. Para realizar esta selección se ha entendido como técnica un "sistema de acciones", intencionalmente sistematizado para conseguir los objetivos o resultados de esa técnica. Se han incluido, además, los artefactos ya que "la identificación de una técnica con un tipo de artefactos que son sus resultados es una metonimia perfectamente natural, puesto que los resultados de una acción constituyen un buen medio para designar esa acción." (Quintanilla 2005:52)

Con las palabras seleccionadas se conformó un cuerpo de 90 conceptos y sus respectivos comodines de búsqueda para la codificación automática en el programa ATLAS.ti.

\begin{tabular}{|c|c|c|c|}
\hline PALABRA CLAVE & COMODINES & PALABRA CLAVE & COMODINES \\
\hline ACELERADOR & acelerador| & INFRARROJO & infrarrojo*| \\
\hline ADAPTADOR & adaptador*| & INGENIERÍA & ingenie*| \\
\hline ALARMA & alarma|alarmas| & INTERNET & internet| \\
\hline AMBULANCIA & ambulancia*| & JOYSTICK & joystick*| \\
\hline AMORTIGUACIÓN & amortigua*| & LAVADORA & |avadora*| \\
\hline AMPLIFICACIÓN & amplifica*| & LOCOMOCIÓN & locomo*| \\
\hline ANDADOR & andador* & MODEM & $\mathrm{m}[$ oó]dem*| \\
\hline APARATO & aparato|aparatos| & MAGNÉTICO & magnétic*| \\
\hline APPLE & apple| & MÁQUINA & máquina*| \\
\hline ARMARIO & armario*| & MICROELECTRÓNICA & microelect* \\
\hline ASCENSOR & ascensor|ascensores| & MICROPROCESADORES & micrófono*| \\
\hline ASIDERO & asidero*| & MICRÓFONO & microprocesador* \\
\hline ASIENTO & asiento* & MÓVIL & móvil*| \\
\hline AUDÍFONO & audífono*| & MULETA & muleta*| \\
\hline
\end{tabular}


Parte II. Aplicación de un modelo de cultura científico-tecnológica en las personas con discapacidad

\begin{tabular}{|c|c|c|c|}
\hline AUTOBÚS & autob[uú]s*| & NETWORK & network| \\
\hline AUTOMOCIÓN & automo* & OFFICE & office| \\
\hline AVIÓN & avi[oó]n*| & ORDENADOR & ordenador*| \\
\hline BASTÓN & bast[oó]n*| & ORTÉSICA & ort[eé]si*| \\
\hline BIOMATERIAL & biomaterial $^{*} \mid$ & ORTOPEDIA & ortop[ée] ${ }^{*} \mid$ \\
\hline BIOMECÁNICA & biomecánic*| & ORTOPROTÉSICA & ortoprot*| \\
\hline BIOTECNOLOGÍA & biotecnología| & PARLANTE & parlante* \\
\hline BIT & bit|bits & POLITÉCNICA & politécnic*| \\
\hline BRAILLE & braille & PROTÉSICO & pr[oó]t[eé]si*| \\
\hline CALZADO & calzado*| & PROTOTIPO & prototipo*| \\
\hline CARROCERÍA & carrocería|chasis| & RADIOCOMUNICACIÓN & radioc*| \\
\hline CINTURÓN & cintur[oó]n*| & RATÓN & ratón|ratones | \\
\hline COCLEAR & coclear* | & RELOJ & reloil \\
\hline COJíN & cojín|cojines | & ROBOT & rob[oó]t*| \\
\hline COLCHÓN & colch[oó]n*| & RUEDA & rueda*| \\
\hline COMPUTACIÓN & comput*| & SEMÁFORO & semáforo*| \\
\hline COMUNICACIÓN & comunicación & & \\
\hline AUMENTATIVA & aumentativa| & SILLA & silla|sillas $\mid$ \\
\hline CONMUTADOR & conmutador*| & SINTETIZADOR & sintetizador*| \\
\hline CONTESTADOR & contestador*| & SOFTWARE & software| \\
\hline CORSÉ & corsé* $^{*}$ corselete* $\mid$ & TAXI & taxi $\mid$ taxis $\mid$ \\
\hline DIGITAL & digital $^{*} \mid$ & TECLADO & tecla*| \\
\hline DOMÓTICA & domótic*| & TELEFONÍA & tel[eé]fon*| \\
\hline ELECTRICIDAD & el[eé]ctric*| & TELEASISTENCIA & teleasistencia| \\
\hline ELECTRÓNICA & electr[oó]*| & TELECOMUNICACIÓN & telecomunicaci* \\
\hline ERGONOMIIA & erg[oó]n*| & TELEMÁTICA & telemátic*| \\
\hline ESCALERA & escalera*| & TELETEXTO & teletexto | \\
\hline EUROTAXI & eurotaxi*| & TIFLOTÉCNICA & tiflotécnic*| \\
\hline HARDWARE & hardware| & VIDEO & v[ií]deo*| \\
\hline HIDRÁULICA & hidráulic*| & VEHÍCULO & vehículo*| \\
\hline $\mathrm{HIFI}$ & hifil & WEB & web| \\
\hline INFORMÁTICA & inform[aá]ti*| & ZAPATO & zapato*| \\
\hline
\end{tabular}

Tabla 5.3 Comodines de búsqueda de los aparatos tecnológicos y técnicas 
Luego de la identificación automática de los términos en el texto se procedió a identificar manualmente las imágenes o valores relacionados directamente en el mismo párrafo con las tecnologías encontradas.

Se identificaron los aspectos valorativos referentes a la tecnología, que Minusval transmite a sus lectores, destacando la diferencia entre las imágenes o valores que se reconocen como propios de una tecnología y aquellos que se desearía que caracterizaran al aparato o técnica, según las siguientes categorías encontradas en el texto mediante un análisis cualitativo:

\begin{tabular}{|c|c|}
\hline \multicolumn{2}{|c|}{ A. Imágenes o Valores Reconocidos Positivos } \\
\hline 1. Accesibilidad & 26. Importancia \\
\hline 2. Aceptación & 27. Independencia \\
\hline 3. Adecuación & 28. Innovación \\
\hline 4. Alivio & 29. Integración \\
\hline 5. Apoyo & 30. Inteligencia \\
\hline 6. Avance & 31. Interesante \\
\hline 7. Barato & 32. Lúdico \\
\hline 8. Beneficio & 33. Mejora \\
\hline 9. Bienestar & 34. Moderno \\
\hline 10. Calidad & 35. Natural \\
\hline 11. Calidad de Vida & 36. Necesario \\
\hline 12. Cambio & 37. Oportunidad \\
\hline 13. Cercanía & 38. Potencia \\
\hline 14. Comodidad & 39. Positivo \\
\hline 15. Comunicación & 40. Precisión \\
\hline 16. Confianza & 41. Rapidez \\
\hline 17. Efectividad & 42. Respeto \\
\hline 18. Eficacia & 43. Seguridad \\
\hline 19. Eficiencia & 44. Sencillez \\
\hline 20. Esperanza & 45. Solución \\
\hline 21. Equilibrio & 46. Tranquilidad \\
\hline 22. Facilitar & 47. Útil \\
\hline 23. Favorecer & 48. Validez \\
\hline
\end{tabular}


Parte II. Aplicación de un modelo de cultura científico-tecnológica en las personas con discapacidad

\begin{tabular}{ll}
\hline 24. Fiabilidad & 49. Variedad \\
\hline 25. Igualdad & 50. Ventaja \\
\hline & 51. Versatilidad \\
\hline
\end{tabular}

Tabla 5.4 Imágenes o valores reconocidos positivos

\begin{tabular}{ll}
\hline B. Imágenes o Valores Reconocidos Negativos & \\
\hline 1. Brecha & 14. Ineficiencia \\
\hline 2. Caro & 15. Injusto \\
\hline 3. Complejidad & 16. Inseguridad \\
\hline 4. Dependencia & 17. Insuficiencia \\
\hline 5. Desigualdad & 18. Miedo \\
\hline 6. Desventaja & 19. Molestia \\
\hline 7. Dificultad & 20. Nocivo \\
\hline 8. Estresante & 21. Problema \\
\hline 9. Exceso & 22. Rechazo \\
\hline 10. Exclusión & 23. Riesgo \\
\hline 11. Inadecuado & 24. Sedentarismo \\
\hline 12. Incompatibilidad & 25. Viejo \\
\hline 13. Incompleto & \\
\hline
\end{tabular}

Tabla 5.5 Imágenes o valores reconocidos negativos

\section{Imágenes o Valores Deseados}

\begin{tabular}{ll}
\hline 1. VD Accesibilidad & 11. VD Igualdad \\
\hline 2. VD Adecuación & 12. VD Independencia \\
\hline 3. VD Agradable & 13. VD Integración \\
\hline 4. VD Asequible & 14. VD Inteligencia \\
\hline 5. VD Barato & 15. VD Naturalidad \\
\hline 6. VD Brindar Facilidades & 16. VD Mejora \\
\hline 7. VD Comodidad & 17. VD Seguridad \\
\hline 8. VD Compatibilidad & 18. VD Sencillez \\
\hline 9. VD Confianza & 19. VD Utilidad \\
\hline 10. VD Eficiencia & 20. VD Versatilidad
\end{tabular}

Tabla 5.6 Imágenes o valores deseados 


\subsection{Resultados}

\subsubsection{La cultura científico-tecnológica}

Como se ha señalado, el análisis de la revista Minusval se ha efectuado desde el número de septiembre-octubre de 2001 hasta el de julio-agosto de 2006. Los datos generales de esta parte del estudio son:

\begin{tabular}{lr}
\hline Total de revistas analizadas & 37 \\
Total de párrafos analizados & 33.028 \\
Promedio de párrafos por revista & 893 \\
Total de palabras & 1.498 .381 \\
\hline
\end{tabular}

Tabla 5.7 Datos generales cuantitativos de la revista Minusval

Para analizar la cultura científico-tecnológica transmitida por la revista fue necesario identificar, en primer lugar, la presencia de los conceptos básicos "ciencia" y "tecnología". Se localizaron un total de 2.950 referencias a estas palabras, de las cuales, una amplia mayoría eran tecnológicas: un $83,7 \%$.

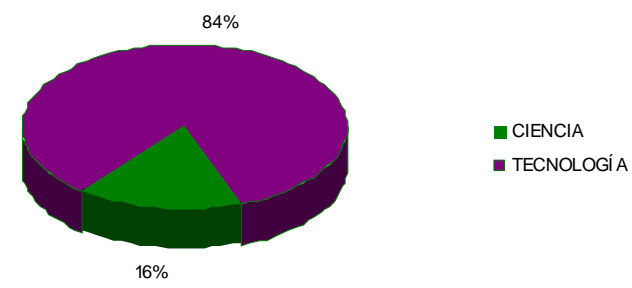

Fig. 5.1 Ciencia y tecnología en la revista Minusval

Es importante resaltar que no siempre que se encuentra presente uno de de estos términos es posible identificar el tipo de información cultural que transmite, en ocasiones aparecen como palabras aisladas o en un contexto insuficiente para clasificar su contenido. Por lo tanto, el número final de referencias analizadas es levemente inferior: 2.617 . 
Parte II. Aplicación de un modelo de cultura científico-tecnológica en las personas con discapacidad

\subsubsection{Cultura científica}

A través de un análisis manual y siguiendo el modelo de cultura científicotecnológica de Quintanilla se cuantificó el tipo de información representacional, práctica o valorativa - que se transmitía en cada frase o párrafo donde estuvieran presentes los términos "ciencia"o "tecnología".

En lo que corresponde a la cultura científica, se encontró un total de 477 referencias, cuyo desglose por tipo de información vemos a continuación:

\begin{tabular}{ccccccc}
\hline \multicolumn{7}{c}{ Cultura Científica } \\
\hline Total & Rep. Int. & Rep. Ext. & Prct. Int. & Prct. Ext. & Vlr. Int. & Vlr. Ext. \\
\hline 477 & $16,1 \%$ & $25,4 \%$ & $15,3 \%$ & $34,6 \%$ & $1,9 \%$ & $6,7 \%$ \\
\hline
\end{tabular}

Tabla 5.8 Cultura científica en la revista Minusval

Los contenidos referidos a prácticas o comportamientos en relación con la ciencia son los que predominan con un porcentaje acumulado entre intrínsecos y extrínsecos del 49,9\% de las menciones. La otra mitad la conforman las representaciones, con una clara hegemonía sobre las valoraciones, ya que estás últimas sólo alcanzan el 8,6\% del total de cultura científica.

Según esta información sobre ciencia, fuera incorporada o no incorporada, tenemos los siguientes gráficos. Hay un total de 159 párrafos en los que se transmite información científica intrínseca. Un 48\% corresponde a conocimiento científico y un $46 \%$ a normas o reglas y formas de comportamiento dentro del sistema científico. Tan sólo un $6 \%$ tiene relación con valores intrínsecos a la ciencia. 


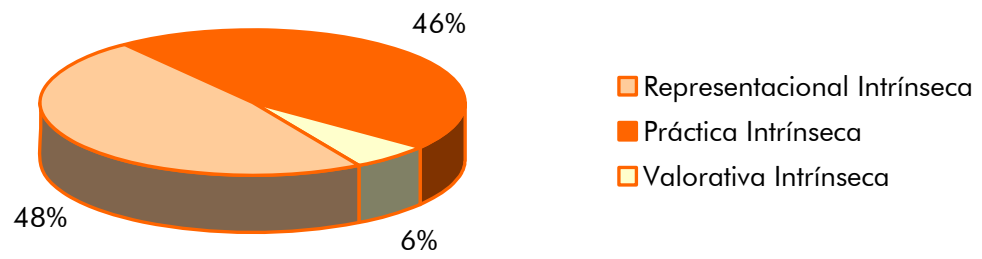

Fig. 5.2 Cultura científica intrínseca en la Minusval

Un ejemplo de información científica intrínseca es la explicación que se da en el siguiente párrafo de los efectos positivos de la risa y el buen humor.

Volviendo a las explicaciones científicas, ¿̇por qué el humor produce todos estos efectos positivos? Para José Elías, cuando nos reímos favorecemos la producción y liberación de sustancias bioquímicas como la dopamina, neurotransmisor que nos eleva el estado de ánimo, que puede resultar muy positivo para que personas con tendencias suicidas las abandonen. O la serotonina, tipo de endorfina con efectos calmantes y analgésicos y la adrenalina, que nos permite estar más despiertos y receptivos, proporcionándonos mayor creatividad. (Minusval № 134. Mayo - Junio 2002)

Aquí encontramos conocimiento científico, se nos explica qué es la dopamina ("neurotransmisor que nos eleva el estado de ánimo") y en qué consiste la serotonina ("tipo de endorfina con efectos calmantes y analgésicos y la adrenalina, que nos permite estar más despiertos y receptivos, proporcionándonos mayor creatividad"). Esta información no es una opinión o la personal visión de alguien sobre el mundo, es conocimiento fruto de investigaciones rigurosas y sometidas al escrutinio de científicos. Es, por lo tanto, contenido intrínseco a la ciencia. 
Parte II. Aplicación de un modelo de cultura científico-tecnológica en las personas con discapacidad

La información práctica intrínseca, que se encuentra en un porcentaje muy similar a la representacional en esta publicación, es aquella que da pautas o nos indica acciones científicas, como la que vemos a continuación:

Científicos, neurólogos, pediatras, neurofisiólogos y terapeutas de todo el mundo se dieron cita en la ciudad de Bled, República de Eslovenia, para intervenir de forma activa en este $V$ Congreso Internacional, con exposiciones y debates de alto nivel científico destinados a prevenir, detectar y tratar la parálisis cerebral que afecta a quince millones de personas a nivel mundial, la mitad con algún grado de retraso mental y un tercio con epilepsia. (Minusval № 131. Noviembre - Diciembre 2001)

En este ejemplo se advierte una práctica, la realización de un encuentro ("V Congreso Internacional") entre especialistas ("Científicos, neurólogos, pediatras, neurofisiólogos y terapeutas") que mediante intercambio de información científica avanzan en el estudio de una enfermedad.

Pero este no es el único caso de prácticas internas reflejadas en la Minusval. Otros comportamientos entendidos como intrínsecos que observamos son publicar en revistas especializadas, plantear hipótesis con su posterior comprobación empírica, llevar a cabo un control experimental en grupos de control, diseñar herramientas para la investigación, etc.

Por otra parte, la información cultural transmitida tiene un contenido valorativo cuando se refiere a preferencias, actitudes o valores. Este conocimiento es intrínseco cuando da a conocer aquellos valores científicos inherentes como, por ejemplo, búsqueda de la verdad, rigor o certeza. 
Los programas actuales de investigación han planificado nuevos estudios para precisar con mayor rigor científico y réplica independiente de las hipótesis sobre otros posibles factores causantes del trastorno autista. (Minusval № 152. Julio - Agosto 2005)

El rigor es un valor propio de la ciencia que, como señalaba Robert K. Merton (1977), busca la verdad independientemente de subjetividades individuales siguiendo una moral considerada obligatoria para el hombre de ciencia.

Hemos visto que, dentro de la información científica intrínseca, son los conocimientos representacionales y prácticos los que tienen mayor difusión en esta revista. Es decir, aquellos que entregan datos, por una parte, de cómo es la realidad desde un punto de vista científico y, por otra, de las acciones que se realizan siguiendo normas propias del sistema científico.

En cuanto a la cultura científica extrínseca, que está fuera de la ciencia, pero que la afecta de una $u$ otra manera, en la revista Minusval hemos encontrado casi el doble de referencias que de la información intrínseca. De estos 318 párrafos en los cuales se aprecia la presencia de información científica extrínseca, destacan con un $52 \%$ aquellas que hacen referencia a normas o reglas de actuación consideradas como dignas de ser cumplidas o las pautas efectivas o hábitos de comportamiento observadas en la práctica del grupo. 


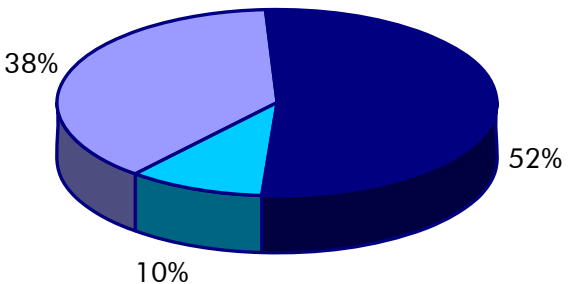

Representacional

Extrínseca

Práctica Extrínseca

口Valorativa Extrínseca

Fig. 5.3 Cultura científica extrínseca en la Minusval

El $38 \%$ de los casos corresponde a información con contenidos representacionales y tan sólo el 10\% transmite valoraciones extrínsecas sobre la ciencia y la tecnología.

Para clarificar los conceptos podemos ver cómo en el siguiente párrafo de la revista se proyecta una imagen de la ciencia sin estar respaldada por conocimiento científico (información representacional no incorporada). El hecho de que la ciencia sea vista como una variable fundamental de la democracia tiene directa relación con la ciencia, pero no afecta a su composición intrínseca.

En la sociedad basada en el conocimiento, la democracia requiere ciudadanos y ciudadanas con ciertos conocimientos científicos y técnicos como parte de sus habilidades básicas. Ello supone que las personas necesitan una serie de habilidades y competencias para participar en la sociedad actual, y éstas han debido ser desarrolladas al finalizar la formación escolar, pero deben continuarse a lo largo de toda la vida. (Minusval № 137. Noviembre - Diciembre 2002)

En el párrafo precedente se destaca la imagen del conocimiento científicotécnico como una habilidad básica para la participación de los ciudadanos en la sociedad. Esta visión de la ciencia, sin embargo, no 
cambia el funcionamiento interno del método científico ni de la información científica ni de sus valores incorporados.

Por otro lado, es también extrínseco a la ciencia, el reconocimiento público otorgado por los premios, como el que vemos a continuación, que si bien siguen normas y pautas más o menos rígidas en la evaluación de las candidaturas, es una práctica social fuera de los márgenes de lo estrictamente científico.

Convocados por el ministerio de Trabajo y Asuntos Sociales a través del Real Patronato sobre Discapacidad, los Premios Reina Sofía 2002 tienen como objetivo recompensar una labor continuada llevada a cabo por un período de tiempo no inferior a diez años de investigación científica o de trabajo sanitario programado y evaluado científicamente cuyos resultados sean merecedores de esta distinción. (Minusval № 132. Enero - Febrero 2002)

Estas prácticas muchas veces refuerzan la actividad científica, dentro del contexto social en el que se efectúan; pero no son parte de sistema científico intrínseco.

Finalmente, observemos cómo en el siguiente ejemplo se aprecia una valoración en cuanto a la aplicación de los conocimientos científicos para la salud humana. Vemos como los valores de equidad, justicia y solidaridad, son externos a la ciencia, pero indiscutiblemente tienen una directa influencia en la imagen que de ella se tiene.

Se abre la posibilidad de alargar la vida humana hasta límites ahora difícilmente imaginables. Si los conocimientos se aplican con equidad, justicia y solidaridad transcurrirá en buenas condiciones de salud. (Minusval № 131. Noviembre - Diciembre 2001) 
Parte II. Aplicación de un modelo de cultura científico-tecnológica en las personas con discapacidad

\subsubsection{Cultura tecnológica}

La revista Minusval ofrece a sus lectores una mayor cantidad de información referente a la cultura tecnológica. La cantidad de párrafos en los que encontramos este tipo de conocimiento es más de 4 veces superior a aquella donde hay información referida a la ciencia.

\begin{tabular}{ccccccc}
\hline \multicolumn{8}{c}{ Cultura Tecnológica } \\
\hline Total & Rep. Int. & Rep. Ext. & Prct. Int. & Prct. Ext. & Vlr. Int. & Vlr. Ext. \\
\hline 2.140 & $4,0 \%$ & $40,7 \%$ & $1,9 \%$ & $39,3 \%$ & $1,7 \%$ & $12,4 \%$ \\
\hline
\end{tabular}

Tabla 5.9 Cultura tecnológica en la revista Minusval

Pero al igual que en el caso de la ciencia, la información representacional y la práctica, ambas extrínsecas, son las que predominan con porcentajes muy similares $(40,7 \%$ y $39,3 \%$ respectivamente).

Comenzaremos analizando la cultura tecnológica intrínseca. En el siguiente gráfico podemos observar la distribución de los tipos de información incorporada a los sistemas técnicos que se transmiten en la revista.

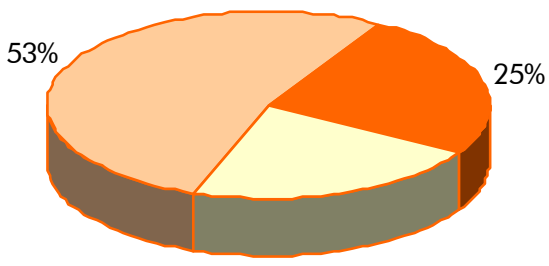

Representacional Intrínseca

Práctica Intrínseca

$\square$ Valorativa Intrínseca

$22 \%$

Fig. 5.4 Cultura tecnológica intrínseca en la Minusval 
De los 163 párrafos en los que se entrega información de tecnología, el $53 \%$ es referido a conocimientos, creencias o representaciones acerca de los componentes, estructura y funcionamiento intrínseco al sistema. Como vemos en el siguiente ejemplo, que representa brevemente el funcionamiento de un implante coclear.

Esta nueva técnica, inexistente hasta los años 70, consiste en una prótesis auditiva implantada quirúrgicamente en el oído interno que transmite las señales por micrófono externo y un procesador hasta llegar a un receptor y unos electrodos implantados en la cóclea. (Minusval № 130. Septiembre - Octubre 2001)

Además, dentro de los contenidos incorporados a la tecnología, vemos que la información de prácticas (25\%) y valores $(22 \%)$ se encuentra poco presente y en porcentajes parecidos.

Dentro de las normas intrínsecas de la tecnología actuales podemos considerar las pautas WAI (Iniciativa para la Accesibilidad de la Web) desarrolladas por el Consorcio World Wide Web, como vemos a continuación:

Cada vez más proyectos de investigación y desarrollo tecnológico del Programa sobre las tecnologías de la sociedad de la información del Quinto Programa Marco utilizan las pautas desarrolladas por la Iniciativa de Accesibilidad a la Web. (Minusval № 131. Noviembre - Diciembre 2001)

Son valores intrínsecos a la tecnología los vinculados a sus objetivos y resultados como el valor de la eficiencia o, como observamos en el siguiente párrafo, la accesibilidad:

Las personas con discapacidades y las personas de edad se enfrentan a toda una serie de barreras técnicas a la hora de acceder a Internet. La accesibilidad de éstos y de otros usuarios podría mejorarse 
Parte II. Aplicación de un modelo de cultura científico-tecnológica en las personas con discapacidad

considerablemente mediante una adecuada codificación en el momento de la creación de los sitios web y de concepción de sus contenidos, y mediante el respeto de unas normas simples de estructura y maquetación al diseñar las páginas web. (Minusval № 131. Noviembre - Diciembre 2001)

Por otra parte, hemos dicho que la información no incorporada en la cultura tecnológica es aquella que se refiere a los sistemas técnicos, que no forma parte de éstos, pero que es relevante para su diseño, producción y uso. Al revisar los 37 números de la Minusval hemos encontrado que las referencias al conocimiento tecnológico extrínseco superan con creces a las halladas de información incorporada: 1.977 párrafos transmiten información tecnológica extrínseca.

En la Fig. 5.5 podemos ver el equilibrio entre la información representacional y la práctica. Además, se deduce una mayor transmisión de valores no incorporados a los sistemas técnicos, con 257 referencias (13\% de lo extrínseco); frente a las 35 alusiones a los valores intrínsecos, como se observa en párrafos anteriores.

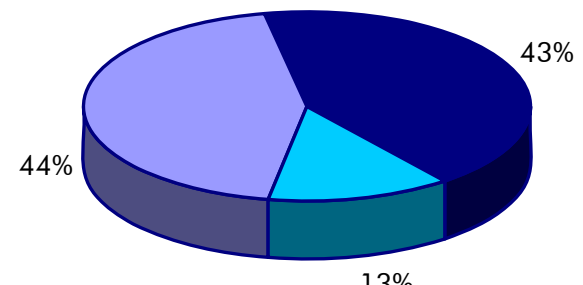

$13 \%$ $\square$ Representacional Extrínseca

Práctica Extrínseca

$\square$ Valorativa Extrínseca

Fig. 5.5 Cultura tecnológica extrínseca en la Minusval

Los contenidos que expresan una visión o representación de la tecnología desde una perspectiva extrínseca representan el $44 \%$ de la cultura 
tecnológica no incorporada transmitida en las páginas de la revista Minusval. En el siguiente ejemplo se observa una visión de la relación entre los seres humanos y la tecnología desde un punto de vista externo.

La tecnología está cambiando la relación hombre-objeto y hombremáquina. La última década se ha caracterizado, sin duda, por el fuerte desarrollo y la amplia difusión de nuevos materiales, las tecnologías electrónicas y las tecnologías informáticas. La consecuencia de esto ha sido la aparición de una nueva generación de objetos, los llamados "objetos tecnológicos", relacionados con los nuevos medios de comunicación: los ordenadores de bolsillo, Internet, móviles, MP3, notebook. (Minusval № 133. Marzo - Abril 2002)

En estas líneas se nos transmite una representación de cómo el ser humano se relaciona con los objetos, con las máquinas y cómo la incorporación de nuevos materiales al diseño y construcción de aparatos tecnológicos afecta la comunicación.

Por su parte, aquella información de normas de conducta o pautas a seguir, ocupa un $43 \%$ de los conocimientos tecnológicos extrínsecos. Entre ellos podemos poner como ejemplo los premios a la innovación tecnológica o la colaboración entre diferentes agentes sociales para la creación de una red de tecnologías de ayuda, como vemos a continuación:

En la elaboración de la red EASTIN, se ha prestado particular atención a la validación de los resultados que poco a poco se delineaban, a través de la interacción con tres grupos principales de interlocutores: los usuarios directos de las ayudas técnicas (personas con discapacidad y sus familiares), los profesionales de la sanidad y de los servicios sociales, la industria y la distribución de las tecnologías de apoyo. Con tal fin, se han reclutado en los distintos países tres grupos representativos de dimensión considerable (360 usuarios directos de las ayudas, 210 agentes sociosanitarios, 84 agentes de la industria y del mercado), a los cuales se 
Parte II. Aplicación de un modelo de cultura científico-tecnológica en las personas con discapacidad

les ha pedido, al tiempo que la red tomaba forma, que expresasen sus opiniones y sugerencias. (Minusval Dossier Proyecto EASTIN. Septiembre Octubre 2005)

En tercer lugar, dentro de la información cultural tecnológica presente en la revista, encontramos contenidos valorativos extrínsecos, como la búsqueda de la igualdad de acceso de un colectivo determinado a cierto tipo de productos tecnológicos como son las ayudas técnicas.

Frente a este problema es el momento de reivindicar el derecho de las personas discapacitadas al acceso a las Ayudas Técnicas. (Minusval Dossier Proyecto EASTIN. Septiembre - Octubre 2005)

\subsubsection{Cultura incorporada y no incorporada (intrínseca v/s extrínseca)}

Hasta ahora hemos analizado la presencia de conocimientos científicos y tecnológicos, en términos generales, en los textos publicados por la revista Minusval. Para complementar la caracterización de la cultura científicotecnológica transmitida por esta publicación desde y hacia las personas con discapacidad, es necesario observar los datos desde otro punto de vista.

Recordemos que toda información transmitida por aprendizaje social conforma la cultura de un grupo determinado. En este caso veremos si la cultura científico-tecnológica de la revista Minusval posee más componentes intrínsecos o extrínsecos. Esto es, si la información que llega a las PCD por este medio, se refiere a elementos internos o externos de la ciencia y/o tecnología. 


\section{Intrínseca}

En primer lugar describiremos lo que hemos encontrado de información intrínseca. Como vemos en la Tabla 5.10, el total de párrafos que transmiten conocimientos incorporados alcanza sólo a los 323. Destacan las representaciones de la tecnología $(26,6 \%)$ y la ciencia $(23,8 \%)$ y las prácticas científicas intrínsecas $(22,6 \%)$. En términos absolutos, estas cifras son pequeñas al compararlas con las referencias a la información extrínseca, como veremos posteriormente.

\begin{tabular}{ccccccc}
\hline \multicolumn{7}{c}{ Cultura Científico-Tecnológica Intrínseca } \\
\hline Total & Cnt. Rep. & Cnt. Prct. & Cnt. Vlr. & Tcn. Rep. & Tcn. Prct. & Tcnl. Vlr. \\
\hline 323 & $23,8 \%$ & $22,6 \%$ & $2,8 \%$ & $26,6 \%$ & $12,7 \%$ & $11,5 \%$ \\
\hline
\end{tabular}

Tabla 5.10 Cultura científico-tecnológica intrínseca en la revista Minusval

Al desglosar estos resultados, percibimos que la información científica y la tecnológica intrínsecas se presentan en cantidades similares. Hay 159 párrafos en los que se hace alusión a la ciencia y 164 que mencionan datos tecnológicos.

Como veíamos en la figura 5.2, cuando la información se refiere a la ciencia, los conocimientos representacionales y prácticos son semejantes y abarcan casi la totalidad de la cultura científica intrínseca.

En cambio, cuando los conocimientos transmitidos son tecnológicos, predomina la información representacional con un 52\% (ver figura 5.4). 
Parte II. Aplicación de un modelo de cultura científico-tecnológica en las personas con discapacidad

Estos datos nos dicen que a la hora de transmitir conocimientos internos de ciencia o tecnología, en la revista Minusval hay una mayor presencia de contenidos, creencias y representaciones conceptuales o simbólicas (representacionales); seguidos por reglas y pautas de comportamiento (prácticos), para finalmente ocuparse de los objetivos, valores y preferencias (valorativos).

\section{Extrínseca}

Pasemos ahora a revisar los contenidos externos a la CyT que hemos identificado en este estudio. El número total de referencias a la información externa a la ciencia y la tecnología es notoriamente superior al de la interna. Los párrafos en los que hemos identificado cultura científico-tecnológica extrínseca llegan a 2.294. En la siguiente tabla observamos que en este caso la información tecnológica es la protagonista.

Cultura Científico-Tecnológica Extrínseca

\begin{tabular}{ccccccc}
\hline Total & Cnt. Rep. & Cnt. Prct. & Cnt. Vlr. & Tcn. Rep. & Tcn. Prct. & Tcn. Vlr. \\
\hline 2.294 & $5,3 \%$ & $7,2 \%$ & $1,4 \%$ & $38,0 \%$ & $36,6 \%$ & $11,6 \%$ \\
\hline
\end{tabular}

Tabla 5.11 Cultura científico-tecnológica extrínseca en la revista Minusval

En total, el conocimiento tecnológico representa el $86,2 \%$ con 1.976 párrafos. De esta cifra, nuevamente observamos una similitud entre la información representacional y la práctica (ver figura 5.5), con $45 \%$ y $42 \%$, respectivamente.

La presencia de cultura científica extrínseca es secundaria, con sólo 318 párrafos. De ellos, el $52 \%$ corresponde a información con contenido práctico, le sigue la representacional con un $38 \%$ y, finalmente, la que hace alusión a valores con un 10\% (ver figura 5.3). 
Resumiendo, podemos señalar que la cultura científico-tecnológica que se transmite en las páginas de la revista Minusval tiene una mayor presencia de contenidos extrínsecos, es decir, aquellos que si bien inciden en la ciencia y la tecnología, no forman parte incorporada de ellas. Dentro de esta información externa, destaca con diferencia, la asociada a la tecnología. Por otro lado, a pesar de la limitada presencia de contenidos intrínsecos, la información científica y la tecnológica se encuentran en igualdad de condiciones.

\subsubsection{Tipos de información}

Para completar este análisis de la cultura científico-tecnológica de las personas con discapacidad a través de los textos de una publicación especializada revisaremos los datos según el tipo de información transmitida: representacional, práctica o valorativa.

Previamente, observamos en la figura 5.10 que, en términos generales, los contenidos asociados a imágenes, símbolos, formas de ver el mundo (representacionales) y aquéllos que tienen que ver con normas o reglas y formas de comportamiento (prácticas) son los que predominan.

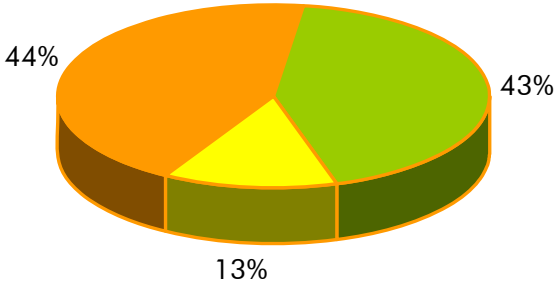

Fig. 5.6 Tipo de información transmitida en la Minusval 
Parte II. Aplicación de un modelo de cultura científico-tecnológica en las personas con discapacidad

\subsection{Información Representacional}

Examinaremos, en primer lugar, aquellos contenidos que hacen alusión a los conocimientos, creencias y representaciones conceptuales o simbólicas de la ciencia y la tecnología. Al advertir el gran porcentaje de información tecnológica extrínseca $(75,4 \%)$ podemos colegir que la revista Minusval centra su visión en la tecnología, y lo hace desde una perspectiva externa a los sistemas tecnológicos.

\begin{tabular}{ccccc}
\hline \multicolumn{5}{c}{ Cultura Representacional } \\
\hline Total & $\begin{array}{c}\text { Científica } \\
\text { Intrínseca }\end{array}$ & $\begin{array}{c}\text { Científica } \\
\text { Extrínseca }\end{array}$ & $\begin{array}{c}\text { Tecnológica } \\
\text { Intrínseca }\end{array}$ & $\begin{array}{c}\text { Tecnológica } \\
\text { Extrínseca }\end{array}$ \\
\hline 1.155 & $6,7 \%$ & $10,5 \%$ & $7,4 \%$ & $75,4 \%$ \\
\hline
\end{tabular}

Tabla 5.12 Cultura representacional en la revista Minusval

Analicemos el siguiente párrafo:

El desarrollo de la Sociedad de la Información puede considerarse la representación palpable de los efectos de la revolución tecnológica que vivimos en nuestros días y de los cambios que afectan a la forma de acceder al mercado de trabajo, a la educación, a las relaciones personales y, por todo ello, también a la forma de vida. (...) Si se tiene en cuenta que el teléfono fijo tardó 50 años en penetrar masivamente en los hogares y que el teléfono móvil ha tardado tan sólo la décima parte, nos damos cuenta de la importancia que tiene que las nuevas tecnologías sean accesibles y asequibles para la inmensa mayoría de los ciudadanos. (Minusval № 141. Agosto - Septiembre 2003).

En este ejemplo podemos descubrir varios de los elementos que hemos ido definiendo. En primer lugar, se observa con claridad que el tema central es la tecnología: "Sociedad de la Información", "revolución tecnológica", "teléfono fijo", "teléfono móvil". Hay una apreciación de un 
gran cambio, de una revolución provocada por la tecnología y que afecta a la sociedad en distintos flancos: el mercado de trabajo, la educación, las relaciones interpersonales; se piensa que la comunicación en general se ve influenciada por el desarrollo tecnológico. Sin embargo, esta percepción es una imagen de la realidad externa a los componentes, estructura y funcionamiento del sistema.

A nivel intrínseco, hay prácticamente un empate entre la información científica y la tecnológica. Esto es, se entrega la misma cantidad de contenidos incorporados de ciencia y de tecnología, aunque su volumen total es muy pequeño.

\begin{tabular}{ccc}
\hline \multicolumn{3}{c}{ Cultura Representacional Intrínseca } \\
\hline Total & Científica & Tecnológica \\
\hline 163 & $47,2 \%$ & $52,8 \%$ \\
\hline
\end{tabular}

Tabla 5.13 Cultura representacional intrínseca en la revista Minusval

La diferencia es patente al revisar los resultados que tratan las representaciones externas: de 992 referencias, el 87,8\% corresponde a menciones de tecnología. En la revista Minusval abundan las imágenes sobre las tecnologías, en detrimento de las relacionadas con la ciencia.

\begin{tabular}{ccc}
\hline \multicolumn{3}{c}{ Cultura Representacional Extrínseca } \\
\hline Total & Científica & Tecnológica \\
\hline 992 & $12,2 \%$ & $87,8 \%$ \\
\hline
\end{tabular}

Tabla 5.14 Cultura representacional extrínseca en la revista Minusval 
Parte II. Aplicación de un modelo de cultura científico-tecnológica en las personas con discapacidad

\subsection{Información Práctica}

Veamos ahora qué sucede con los conocimientos operacionales, ya sean reglas y pautas de comportamiento o habilidades prácticas. En la Tabla 5.15 observamos que es, nuevamente, la información tecnológica extrínseca la que predomina en este sentido.

\begin{tabular}{ccccc}
\hline \multicolumn{5}{c}{ Cultura Práctica } \\
\hline Total & $\begin{array}{c}\text { Científica } \\
\text { Intrínseca }\end{array}$ & $\begin{array}{c}\text { Científica } \\
\text { Extrínseca }\end{array}$ & $\begin{array}{c}\text { Tecnológica } \\
\text { Intrínseca }\end{array}$ & $\begin{array}{c}\text { Tecnológica } \\
\text { Extrínseca }\end{array}$ \\
\hline 1.119 & $6,5 \%$ & $14,7 \%$ & $3,7 \%$ & $75,1 \%$ \\
\hline
\end{tabular}

Tabla 5.15 Cultura práctica en la revista Minusval

Se transmite, por lo tanto, conocimiento relacionado con reglas de actuación que se refieren a los sistemas técnicos, que no forman parte de éstos, pero que son relevantes para su diseño, producción y uso.

En el siguiente ejemplo, es posible distinguir algunos elementos prácticos de los que hemos hablado:

Un certamen donde como viene siendo tradicional se entregaron los premios a la Innovación Tecnológica que premia servicios y equipamientos con los avances más importantes en ayudas técnicas para las discapacidades. (Minusval № 137. Noviembre - Diciembre 2002)

El premio del que se habla, es una práctica llevada a cabo de manera habitual ("viene siendo tradicional") y que está vinculada a la innovación al servicio de las personas con discapacidad ("premia servicios y equipamientos con los avances más importantes en ayudas técnicas"). Este comportamiento - premiar algo - tiene una conexión con el sistema tecnológico, puede influir en su diseño y producción generando motivación y fijando objetivos, determinar una mayor o menor difusión en 
el mercado y, en consecuencia, un mayor o menor uso por parte de los consumidores; pero todo ello fuera de lo que entendemos como el proceso tecnológico intrínseco.

Si separamos la información práctica intrínseca, sorprende que haya una mayor presencia de contenidos científicos que tecnológicos.

\begin{tabular}{ccc}
\multicolumn{3}{c}{ Cultura Práctica } \\
\hline Total & Cientínseca & Tecnológica \\
\hline 114 & $64 \%$ & $36 \%$ \\
\hline
\end{tabular}

Tabla 5.16 Cultura práctica intrínseca en la revista Minusval

La situación se invierte al examinar los contenidos extrínsecos, que además superan por mucho en cantidad a la información incorporada a la ciencia y/o tecnología.

\begin{tabular}{ccc}
\hline \multicolumn{3}{c}{ Cultura Práctica Extrínseca } \\
\hline Total & Científica & Tecnológica \\
\hline 1.005 & $16,4 \%$ & $83,6 \%$ \\
\hline
\end{tabular}

Tabla 5.17 Cultura práctica extrínseca en la revista Minusval 
Parte II. Aplicación de un modelo de cultura científico-tecnológica en las personas con discapacidad

\subsection{Información Valorativa}

Pasemos ahora a examinar la información cultural transmitida con un contenido valorativo. Recordemos que este tipo de conocimiento entrega información acerca de qué estados de cosas son preferibles, convenientes o valiosos. Como hemos visto la cultura valorativa es la que tiene una menor presencia en la revista Minusval con un 13\% del total, porcentaje que corresponde a 343 párrafos.

Como hemos venido advirtiendo en los anteriores apartados, los contenidos tecnológicos extrínsecos son los que concentran el mayor número de menciones $(77,3 \%)$.

\begin{tabular}{ccccc}
\hline \multicolumn{5}{c}{ Cultura Valorativa } \\
\hline Total & $\begin{array}{c}\text { Científica } \\
\text { Intrínseca }\end{array}$ & $\begin{array}{c}\text { Científica } \\
\text { Extrínseca }\end{array}$ & $\begin{array}{c}\text { Tecnológica } \\
\text { Intrínseca }\end{array}$ & $\begin{array}{c}\text { Tecnológica } \\
\text { Extrínseca }\end{array}$ \\
\hline 343 & $2,6 \%$ & $9,3 \%$ & $10,8 \%$ & $77,3 \%$ \\
\hline
\end{tabular}

Tabla 5.18 Cultura valorativa en la revista Minusval

Revisemos en este párrafo los elementos de valor externos a la tecnología:

La investigación formal en los iMac de Apple es un ejemplo de la intención de convertir el ordenador en un objeto más familiar, lúdico y coloquial, trasladándolo desde el ámbito de los objetos tecnológicos a uno más cercano, el de objeto amigable y con connotaciones afectivas. (Minusval № 133. Marzo - Abril 2002)

Los valores de cercanía ("más cercano"), amistad ("objeto amigable") o el afecto ("connotaciones afectivas") son, en este caso, preferencias que atañen al diseño del ordenador en aspectos más bien estéticos y externos al sistema tecnológico como tal. Lo mismo sucede con la caracterización del computador como un objeto "familiar, lúdico y coloquial". 
Pasando a otro punto, si analizamos según este conocimiento sea incorporado o no incorporado, se observa que la cantidad de información intrínseca es casi insignificante dentro del contexto de las revistas analizadas, siendo mayoritariamente de índole tecnológica; rompiendo así una tendencia que se venía observando dentro de las variables intrínsecas.

\begin{tabular}{ccc}
\hline \multicolumn{3}{c}{ Cultura Valorativa Intrínseca } \\
\hline Total & Científica & Tecnológica \\
\hline 46 & $19,6 \%$ & $80,4 \%$ \\
\hline
\end{tabular}

Tabla 5.19 Cultura valorativa intrínseca en la revista Minusval

Las valoraciones extrínsecas representan casi la totalidad de los contenidos en esta área y sigue siendo la referida a la tecnología la que posee más alusiones en los textos analizados, como se demuestra en la tabla 5.20.

\begin{tabular}{ccc}
\hline \multicolumn{3}{c}{ Cultura Valorativa Extrínseca } \\
\hline Total & Científica & Tecnológica \\
\hline 297 & $10,8 \%$ & $89,2 \%$ \\
\hline
\end{tabular}

Tabla 5.20 Cultura valorativa extrínseca en la revista Minusval 
Parte II. Aplicación de un modelo de cultura científico-tecnológica en las personas con discapacidad

\subsubsection{Relaciones}

Hasta el momento hemos revisado los diferentes tipos de información que conforman la cultura científico-tecnológica dentro de la revista Minusval. Ahora queremos ir un paso más allá para investigar cómo se relacionan entre sí estos contenidos dentro de los textos. Debido al predominio de la tecnología, revisaremos con mayor detenimiento los diferentes aspectos de la cultura tecnológica.

En primer lugar nos detendremos en cómo son las conexiones entre los contenidos incorporados y los no incorporados; posteriormente estudiaremos como se relaciona entre sí los elementos representacionales, operacionales y valorativos vinculados con la tecnología.

\subsection{Relación de la Cultura Tecnológica Intrínseca con la Extrínseca}

Antes de empezar, recordemos una vez más que los conocimientos incorporados a los sistemas técnicos son aquellos que se refieren a creencias o representaciones de los componentes, estructura y funcionamiento del sistema; habilidades prácticas y reglas de actuación que los agentes son capaces de seguir para operar con el sistema, o para diseñarlo y construirlo; $y$, finalmente, a los valores o preferencias asociados a él.

En la presente investigación hemos identificado la presencia de contenidos tecnológicos en los párrafos de los textos de la revista Minusval. No obstante, esta información no aparece aislada y única en cada porción analizada. Generalmente, en un mismo párrafo o en una misma frase encontramos que las ideas expresadas por el autor del texto tienen elementos representacionales, prácticos y valorativos mezclados y complementándose unos con otros. 
Contenidos intrínsecos a la tecnología son, por ejemplo, aquellos que encontramos en un manual de mecánica o en un libro de instrucciones sobre el funcionamiento de una silla de ruedas eléctrica. Es atrayente, por lo tanto, saber cómo esa información se relaciona con el conocimiento extrínseco a la tecnología; cuáles son los tipos de contenidos que tienen mayor afinidad en una publicación como la revista Minusval.

Examinemos el siguiente ejemplo:

Sistema de localización personal Tormes. Tormes es un sistema de navegación personal basado en la tecnología GPS, que permite a las personas ciegas conocer su posición y guiarse a través de una ruta determinada. El dispositivo, fruto de la iniciativa auspiciada por la ONCE (Organización Nacional de Ciegos Españoles) y la empresa GMV Sistemas y con la colaboración de Tele Atlas, está integrado por un anotador Sonobraille, un teclado Braille, un sintetizador de voz, una base de datos cartográfica de diferentes ciudades y un receptor GPS. Tormes permite al usuario solicitar información y recibir datos sobre su posición, es decir, conocer el nombre de la calle y el rumbo a seguir, de forma que el sistema le guía a través del itinerario elegido. Como ventajas añadidas, Tormes asiste al invidente en rutas de nueva creación o elegidas con anterioridad; permite grabar y reproducir el camino recorrido, elemento de especial utilidad en actividades deportivas o en paseos por grandes espacios, hasta ahora, muy problemáticos para este colectivo; y, por último, permite trabajar en modo virtual desde el domicilio o la oficina, gracias a la utilización de los comandos de la aplicación para navegar por la cartografía como si se tratara de un mapa hablado. Mediante esta solución, es posible practicar futuros recorridos y editar rutas a fin de llegar a un punto determinado. (Minusval № 143. Enero - Febrero 2004) 
Parte II. Aplicación de un modelo de cultura científico-tecnológica en las personas con discapacidad

Dentro de este texto es posible detectar distintos tipos de información. Por una parte, observamos la presencia de contenido representacional intrínseco tecnológico: se describen los componentes del sistema de navegación Tormes (anotador Sonobraille, teclado Braille, sintetizador de voz, base de datos cartográfica de diferentes ciudades y receptor GPS). Pero, además, se nos cuenta que la producción de este aparato ha contado con el auspicio de la ONCE y las empresas GMV Sistemas y Tele Atlas, acciones externas al núcleo fuerte del sistema tecnológico. Asimismo describe el uso que se le puede dar a Tormes y valora sus utilidades como ventajas añadidas para el colectivo de personas ciegas.

Continuemos con un caso más donde los diferentes tipos de información cultural aparecen unidos:

Por su parte, la Tecnología de la Rehabilitación (Assistive Technology en inglés) ha tenido gran influencia en la Interacción Persona-Ordenador. Muchos de los dispositivos de interacción no estándares que hoy en día son utilizados por un público más amplio fueron inicialmente concebidos para ser usados por las personas con discapacidad. Los sistemas de control de entorno inalámbricos (usualmente mediante rayos infrarrojos), el control del ratón mediante el seguimiento de la pupila (eye tracking) [Jacob95], o a través de la captación de algún tipo de señal eléctrica

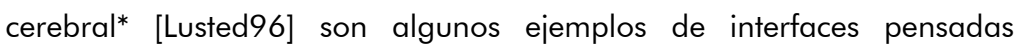
originalmente para las personas con discapacidad. (Minusval, Especial Discapacidad y Nuevas Tecnologías. Junio 2002)

En este párrafo del Especial Discapacidad y Nuevas Tecnologías de la revista Minusval aparecen dos elementos básicos: la visión del cambio de cierto tipo de tecnologías en su relación con los usuarios y la identificación concreta de determinados sistemas. Estos últimos son el control del ratón a través del seguimiento de la pupila (eye tracking) o por señales 
eléctricas cerebrales y los periféricos inalámbricos manejados por rayos infrarrojos.

En cuanto a la imagen que se transmite de la evolución de estas tecnologías, se plantea que han pasado de ser, exclusivamente, tecnologías específicas para personas con discapacidad a ser utilizadas por un público más amplio.

En la Tabla 5.21, vemos que, en total, hay una mayor frecuencia de aparición de información representacional intrínseca en el contexto de contenidos externos en general (39); y que la probabilidad de que estas creencias internas se vinculen con los externos representacionales, operacionales o valorativos es similar entre sí. Destacan las prácticas con un $41 \%$ y, en menor medida, la información representacional (23\%).

\begin{tabular}{|c|c|c|c|c|c|}
\hline & & \multicolumn{4}{|c|}{ Cultura Tecnológica Extrínseca } \\
\hline & & Total & Representacional & Práctica & Valorativa \\
\hline \multirow{3}{*}{$\begin{array}{l}\text { Cultura } \\
\text { Tecnológica } \\
\text { Intrínseca }\end{array}$} & Representacional & 39 & $23,1 \%$ & $41,0 \%$ & $35,9 \%$ \\
\hline & Práctica & 14 & $42,9 \%$ & $35,7 \%$ & $21,4 \%$ \\
\hline & Valorativa & 28 & $60,7 \%$ & $17,9 \%$ & $21,4 \%$ \\
\hline
\end{tabular}

Tabla 5.21 Relación entre la cultura tecnológica extrínseca con la intrínseca en la Minusval

Cuando se trata de los valores intrínsecos a la tecnología, éstos se encuentran vinculados fundamentalmente con representaciones conceptuales externas en un $60,7 \%$ de las 28 referencias identificadas. Donde hay menos co-apariciones de contenidos internos con externos es en el caso de la cultura tecnológica práctica intrínseca, sólo 14; pero cuando existe algún nexo, es primero con representaciones, luego con reglas y pautas de comportamiento $y$, finalmente, con valores. 
Parte II. Aplicación de un modelo de cultura científico-tecnológica en las personas con discapacidad

No olvidemos que estamos revisando aquellos casos en los que en un mismo texto aparecen conjuntamente contenidos extrínsecos e intrínsecos y, por lo tanto, las cifras resultantes no corresponden a la totalidad de las referencias a tales informaciones de manera individual.

\subsection{Relación entre las prácticas y las valoraciones}

En la siguiente tabla (5.22) vemos cómo se asocian los conocimientos operacionales y los valorativos. Casi la totalidad de las coincidencias entre estos dos tipos de contenidos la observamos entre las prácticas extrínsecas y los valores también externos a la tecnología.

\begin{tabular}{llcc}
\hline & & \multicolumn{2}{c}{$\begin{array}{c}\text { Cultura Tecnológica } \\
\text { Práctica }\end{array}$} \\
\cline { 3 - 4 } & & 6 & 86 \\
\hline $\begin{array}{l}\text { Cultura Tecnológica } \\
\text { Valorativa }\end{array}$ & Total & $50,0 \%$ & $5,8 \%$ \\
& Intrínseca & $50,0 \%$ & $94,2 \%$ \\
& Extrínseca & $50,0 \%$ & Execa \\
\hline
\end{tabular}

Tabla 5.22 Relación entre los contenidos prácticos y los valorativos

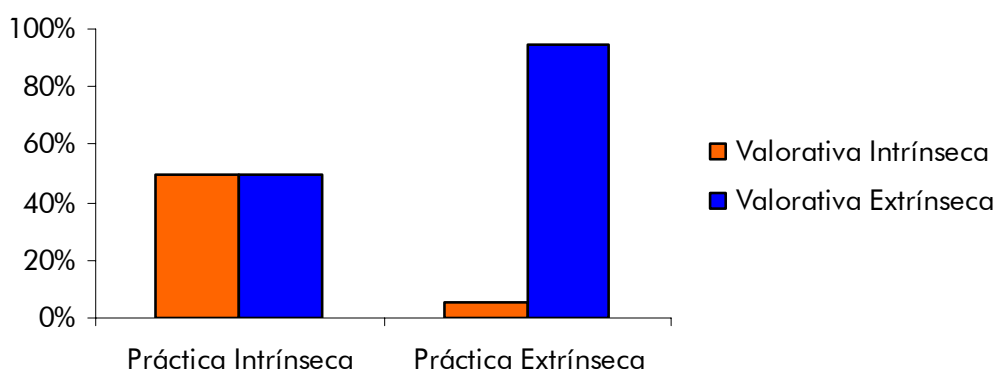

Fig. 5.7 Relación entre los contenidos prácticos y los valorativos 
En el siguiente ejemplo vemos cómo en un mismo texto encontramos unidos, aspectos operacionales y valorativos extrínsecos:

El sistema de provisión efectiva de ayudas técnicas es muy deficitario por lo que muchas personas con discapacidad y personas mayores no pueden disponer de aquellos productos necesarios para su autonomía y participación social. Ni los catálogos de prestaciones ortoprotésicas por parte del sistema sanitario, ni las convocatorias de ayudas técnicas por parte del sistema social están suficientemente coordinados, en ellos no se abarcan suficientemente las necesidades de las personas con discapacidad ni se incorporan los nuevos materiales y las enormes ventajas de nuevas tecnologías. (Minusval Dossier Proyecto EASTIN. Septiembre - Octubre 2005)

En primer lugar, se habla del sistema de provisión de ayudas técnicas a las personas con discapacidad, una práctica externa al sistema tecnológico como tal; se evalúa como "deficitario", pero se transmite el valor de "necesarios para la autonomía y participación social" a tales aparatos, una calificación que determina la preferencia para el uso de determinados productos en concreto.

Por otra parte, vemos, otras prácticas: catálogos de prestaciones ortoprotésicas, desarrollados por el sistema sanitario; convocatorias de ayudas técnicas, realizadas por el sistema social. Estas acciones están vinculadas con la valoración de las nuevas tecnologías como ventajosas para este colectivo social.

\subsection{Relación entre las prácticas y las representaciones}

Observemos ahora cómo se asocian en el texto las reglas y pautas de comportamiento con los conocimientos y/o las creencias conceptuales o simbólicas sobre las técnicas y sobre los sistemas técnicos. 
Parte II. Aplicación de un modelo de cultura científico-tecnológica en las personas con discapacidad

Como en el caso anterior, hay una mayor coincidencia de prácticas tecnológicas con representaciones, ambas extrínsecas. De los 141 casos en los que encontramos en un mismo párrafo contenidos operacionales y representacionales, el $88,7 \%$ corresponde a creencias que se refieren a los sistemas técnicos, pero que no forman parte de ellos (Tabla 5.23).

\begin{tabular}{llcc}
\hline & \multicolumn{2}{c}{$\begin{array}{c}\text { Cultura Tecnológica } \\
\text { Práctica }\end{array}$} \\
\cline { 3 - 4 } & & 12 & 141 \\
\hline $\begin{array}{l}\text { Cultura Tecnológica } \\
\text { Representacional }\end{array}$ & Total & $50,0 \%$ & $11,3 \%$ \\
& Intrínseca & $50,0 \%$ & $88,7 \%$ \\
\hline
\end{tabular}

Tabla 5.23 Relación entre los contenidos prácticos y los representacionales

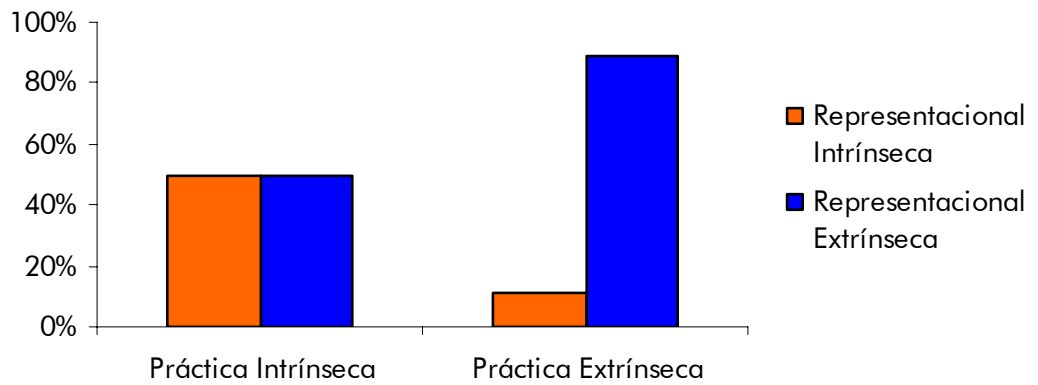

Fig. 5.8 Relación entre los contenidos prácticos y los representacionales

Veamos, en el siguiente ejemplo, estas conexiones:

En conjunto, los resultados expuestos en este breve resumen fortalecen la idea inicial de que la condición de ruralidad dificulta el acceso a nuevas tecnologías a mujeres con discapacidad que viven en este entorno. La inclusión de esta nueva variable de discriminación se muestra entonces como un aspecto de alta relevancia a la hora de evaluar las actuales propuestas de integración, así como también, para la realización de 
futuras políticas de integración tecnológica y social. (Minusval № 144 . Marzo - Abril 2004)

Las acciones y las representaciones están unidas. Por un lado, hay una representación externa, el hecho de vivir en un entorno rural ("ruralidad"), que afectaría negativamente al acceso a las nuevas tecnologías. Por otro, esta visión sería determinante para la realización de políticas de integración, en definitiva, para la creación de normas o pautas para el desarrollo social vinculado con la tecnología.

\subsection{Relación entre los valores y las representaciones}

Nos queda, por último, revisar cómo se vincula la información cultural con contenido valorativo y las imágenes. En la siguiente tabla (5.24) advertimos que son los valores extrínsecos los que más se asocian con la información representacional y que en un $89,6 \%$ de las veces aparecen junto con creencias externas a la tecnología.

\begin{tabular}{llcc}
\hline & \multicolumn{2}{c}{$\begin{array}{c}\text { Cultura Tecnológica } \\
\text { Valorativa }\end{array}$} \\
\cline { 3 - 4 } & & $11 \mathrm{TVI}$ & 12 TVE \\
\hline $\begin{array}{l}\text { Cultura Tecnológica } \\
\text { Representacional }\end{array}$ & Total & 22 & 134 \\
& 07TRI & $22,7 \%$ & $10,4 \%$ \\
& 08TRE & $77,3 \%$ & $89,6 \%$ \\
\hline
\end{tabular}

Tabla 5.24 Relación entre los contenidos valorativos y los representacionales 
Parte II. Aplicación de un modelo de cultura científico-tecnológica en las personas con discapacidad

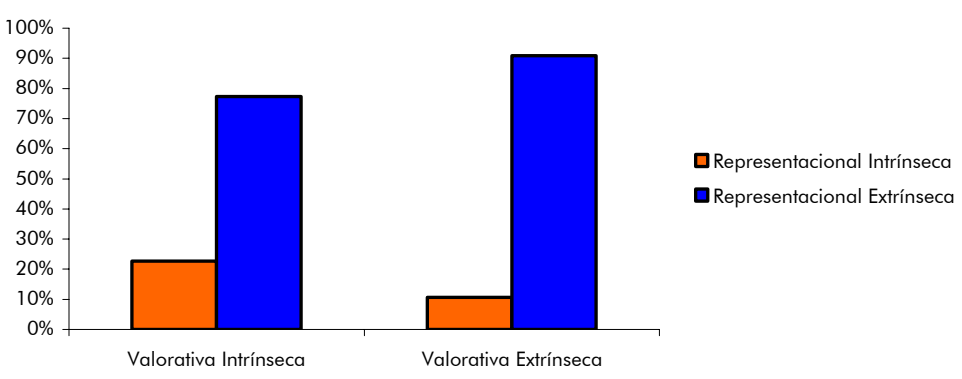

Fig. 5.9 Relación entre los contenidos valorativos y los representacionales

En la revista Minusval podemos encontrar párrafos como éste, que conjuga la presencia de conocimiento extrínseco a la tecnología con valoraciones sobre ella:

Las nuevas tecnologías son un medio formidable para suprimir ciertas barreras y para multiplicar las posibilidades ofertadas a las personas con discapacidad. El derecho de todas las personas con discapacidad a tener un acceso a las mismas oportunidades educativas, en los mismos establecimientos, a todos los niveles que sus compañeros sin discapacidad (educación integrada) y de poder beneficiarse de una enseñanza especializada se encuentra en gran medida aumentado gracias a la disponibilidad de una tecnología adaptada. (Minusval Especial La Discapacidad en Europa. Mayo 2003)

En este ejemplo vemos que se proyecta una imagen de las llamadas nuevas tecnologías como un factor supresor de discriminaciones y catalizador de las opciones para las personas con discapacidad, visión que a la vez de ser una forma de ver ese mundo, tiene connotaciones valorativas. Sin embargo, eso no es todo, se presenta el valor de la igualdad de oportunidad, un objetivo externo a la tecnología, pero que sin lugar de a dudas, atañe al diseño, producción y uso de un aparato tecnológico. 
Capítulo 6. Análisis de la revista Minusval. Las imágenes y valores asociados a las tecnologías. 
Hasta este punto hemos examinado los diferentes tipos de información científica y tecnológica que se transmiten en los textos de la revista Minusval, hemos analizado sus relaciones y hemos advertido la presencia predominante de la tecnología sobre la ciencia en esta publicación.

Otra característica destacable de los contenidos de Minusval es la aparente escasez de valoraciones, apreciaciones y preferencias significativas para el uso y desarrollo de las tecnologías. Decimos aparente porque, si bien hay pocas menciones explícitas a valores - que es lo que hemos recogido hasta el momento - existen representaciones que conllevan un valor en su significado. Se pueden proyectar imágenes y valores positivos sin, necesariamente, utilizar conceptos como "bueno", "bonito", "deseable", etc. Es posible decir lo mismo haciendo uso de otros términos que socialmente son aceptados como positivos y que nos transmiten un valor positivo o, dependiendo de los casos, también negativos.

Para descubrir cómo es la imagen que las personas con discapacidad tienen de la tecnología, hemos identificado automáticamente, como se señala en la metodología ${ }^{18}$, las principales técnicas y aparatos tecnológicos vinculados con la discapacidad. Posteriormente, de manera manual se han analizado todas las imágenes concretas y valores asociados a cada una de las tecnologías descubiertas. A continuación se presentan los resultados obtenidos.

18 Cfr. pp. 115 - 120, en el apartado metodológico del Capítulo 5. 


\subsection{Presencia de imágenes y valores en relación a la tecnología}

En esta investigación se han identificado un total de 991 referencias a imágenes y valores de las diferentes técnicas o aparatos tecnológicos, de los cuales un $68 \%$ (674) representan aspectos positivos y un $19 \%$ (189) se refiere a asociaciones negativas. El 13\% restante corresponde a valores que se desean, características que no se reconocen plenamente como propias de las tecnologías, pero que se anhela que las tuvieran.

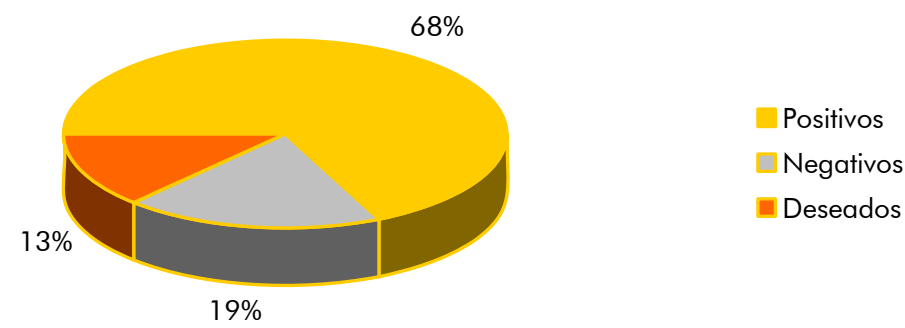

Fig. 6.1 Imágenes y valores asociados a la tecnología

\subsubsection{Positivos}

Trataremos, en primer lugar, aquellas alusiones a la tecnología desde un punto de vista positivo. De las 674 referencias obtenemos 51 imágenes o valores que podemos observar en la siguiente tabla: 


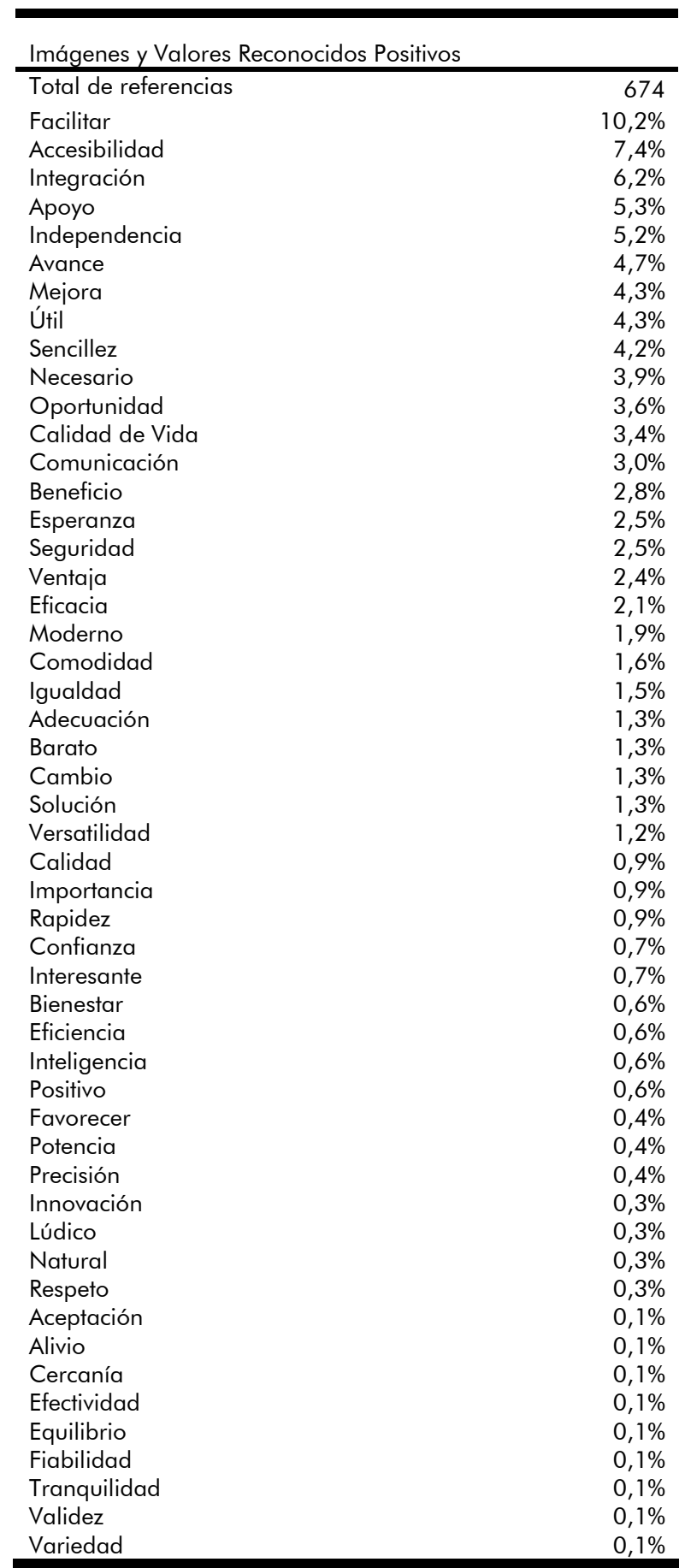

Tabla 6.1 Imágenes y valores positivos 
Parte II. Aplicación de un modelo de cultura científico-tecnológica en las personas con discapacidad

Es importante resaltar que en esta parte del estudio no prestamos atención al peso cuantitativo individual de un valor determinado. Cada mención positiva tenía valor por sí misma ya que en conjunto, nos entregan una visión más compleja a la vez que completa de la tecnología.

La imagen más destacada dentro de la revista Minusval es la de "Facilitar", con un 10,2\% de las alusiones. Esto es, en 68 ocasiones se presenta a la tecnología como un factor o elemento que hace fácil o posible la ejecución de algo o la consecución de un fin $^{19}$ para las personas con discapacidad, en particular, y para la sociedad, en general.

Veamos algunos ejemplos:

Integra la funcionalidad completa de un teléfono móvil junto con muchas de las facilidades que brinda un ordenador personal... (Minusval № 133. Marzo - Abril 2002)

En este caso, es un aparato tecnológico, el ordenador portátil, el que se presenta como elemento que brinda facilidades en general, no especificándose las acciones que posibilita.

El neuropsicólogo experto debe observar los datos y la ejecución de las tareas que los pacientes realizan y de ellos inferir un juicio clínico; el ordenador facilita esta tarea y la hace más confiable. (Minusval, Especial Daño Cerebral. Diciembre 2002)

La tarea beneficiada por la acción facilitadora del ordenador, en este ejemplo, es la que realiza un médico especialista al diagnosticar a un paciente.

\footnotetext{
19 Primera acepción del verbo facilitar según el Diccionario de la Lengua Española Vigésima segunda edición.
} 
"iPronto" es el mando universal concebido por "Philips" para facilitar la gestión central del domicilio desde cualquier dependencia. El aparato está equipado con un panel táctil que permite controlar la iluminación, las cámaras de seguridad y la climatización. (Minusval № 142. Octubre Diciembre 2003)

La facilidad que da la tecnología, también se observa en el entorno doméstico, con ayudas para el control de asuntos como la iluminación, la seguridad y la climatización del hogar.

El teclado ha sido diseñado para facilitar la escritura y la pantalla a color y de generosas dimensiones ofrece mejor visibilidad. (Minusval № 146. Julio - Agosto 2004)

Finalmente, también se distinguen facilidades para las personas con discapacidad visual en la escritura en el ordenador y la lectura en el mismo, a través de elementos visuales especiales para sus necesidades.

Otro valor que se reconoce como positivo presente en las tecnologías es la "Accesibilidad", con un 7,4\%, entendida ésta, como se señala en la misma revista, como un factor que indica si

un producto, servicio, sistema o entorno físico o natural es o no practicable para una persona con movilidad o fuerza reducida en los miembros inferiores o superiores, con discapacidades para ver u oír, con una capacidad limitada para hablar y/o con limitaciones para asimilar el conocimiento. (Minusval № 141. Agosto - Septiembre 2003)

Revisemos algunas frases en las que se reconoce este valor en alguna tecnología.

Tenemos, por una parte, frases en las que se considera a la accesibilidad como un valor intrínseco a la tecnología de sitios Web: 
Parte II. Aplicación de un modelo de cultura científico-tecnológica en las personas con discapacidad

AidCat/IBV es una aplicación Web de navegación fácil y respetuosa con las pautas de accesibilidad a Internet. (Minusval № 153. Septiembre Octubre 2005)

Y por otra, ocasiones en las que la accesibilidad sigue siendo algo externo a la tecnología, una consecuencia del establecimiento de una relación entre el aparato y el usuario.

El equipo mejora la accesibilidad al ordenador, tanto por su condición inalámbrica, como por sus opciones de configuración (...) (Minusval № 146. Julio - Agosto 2004)

Para poder revisar más detalladamente las imágenes y valores positivos que hemos encontrado en las páginas de la revista, las expondremos agrupados en dos categorías: las percibidas como propias de las técnicas y los aparatos tecnológicos y aquéllas consideradas producto de la interacción con la tecnología en un entorno determinado.

Observemos, en primer lugar, las imágenes positivas advertidas en la Minusval vinculadas con los propios aparatos y técnicas. Debemos aclarar que es posible que un mismo párrafo haya sido codificado en varias categorías, según el contenido del texto. A continuación expondremos un ejemplo de cada imagen o valor positivo.

Accesibilidad:

Su información vía web, plenamente accesible, incluye sus Catálogos de Ayudas Técnicas y de Ayudas Artesanales (...) (Minusval № 155. Enero - Febrero 2006) 
Eficacia:

Como señala infomedula.org, los equipos cuentan con ratones controlados por movimientos de cabeza, especialmente eficaces para personas con lesiones medulares altas $y$ de tipo cerebrovascular. (Minusval № 149. Enero - Febrero 2005)

Moderno:

Las modernas técnicas de neuroimagen funcional (tomografía de emisión de positrones, resonancia magnética funcional, magnetoencefalografía...) permiten captar en tiempo real imágenes de los cambios fisiológicos... (Minusval Especial Daño Cerebral. Diciembre 2002)

Adecuación:

En el diseño de la vivienda se ha dado especial importancia a la personalización, por lo que se ha optado por los dispositivos más adecuados para la activación de cada función, activación que puede realizarse mediante botones, con la boca, el pie e, incluso, soplando. (Minusval № 153. Septiembre - Octubre 2005)

Barato:

La Fundación Vodafone trabaja en una aplicación Java que permite cargar dicho software en multitud de teléfonos y acaba con la dependencia del terminal y el elevado coste que representaba la producción de teléfonos adaptados. (Minusval № 144. Marzo - Abril 2004) 
Parte II. Aplicación de un modelo de cultura científico-tecnológica en las personas con discapacidad

\section{Calidad:}

El premio Sidar es un prestigioso galardón que se lleva concediendo desde hace tres años a los sitios WEB que se caracterizan por tener un diseño de calidad... (Minusval № 137. Noviembre - Diciembre 2002)

Rapidez:

Internet, y más en concreto la World Wide Web es probablemente la herramienta más potente de comunicación y difusión de información que podamos encontrar en la actualidad. Su carácter universal, su inmediatez... (Minusval № 136. Septiembre Octubre 2002)

Eficiencia:

Como se puede ver a lo largo de lo expuesto, hemos diseñado un hardware alternativo a los existentes, basado en un microcontrolador, de manera que resulta portable y eficiente, además de económico. (Minusval Especial Discapacidad y Nuevas Tecnologías. Junio 2002)

Inteligencia:

(...) el diseño de una "tarjeta inteligente", capaz de abrir puertas sin necesidad de ponerla en contacto con un lector, ya que actúa a distancia. (Minusval № 133. Marzo - Abril 2002)

Potencia:

Los rápidos progresos de las tecnologías digitales y el descenso de los precios de los equipos de tecnología de la información han puesto en manos de empresas y consumidores unos dispositivos más potentes. (Minusval № 135. Julio - Agosto 2002) 
Precisión:

En concreto, la aplicación NED/IBV SGE permite valorar los rangos de movimiento de las articulaciones de los dedos de la mano, la muñeca, el codo, los dedos de los pies, el tobillo, la rodilla y la cadera, de forma rápida, precisa y repetible. (Minusval № 144. Marzo - Abril 2004)

Natural:

Nacen nuevas tipologías de objetos que ya no tienen nada en común con los utensilios mecánicos y las prótesis motrices y sensoriales a las que estábamos acostumbrados. Se parecen cada vez más a los organismos vivientes (...) (Minusval № 133. Marzo Abril 2002)

Efectividad:

La generalización de la utilización de los ordenadores en el terreno laboral y doméstico, la contribución de estos equipos a la mejora de la calidad de vida y la introducción de Internet en todos los ámbitos de la vida cotidiana ha incrementado la demanda de ayudas técnicas que permitan a estos colectivos la utilización de los dispositivos informáticos con el mayor grado de comodidad y efectividad posible. (Minusval № 144. Marzo - Abril 2004)

Versatilidad:

Por suerte, el ordenador es la máquina más fácilmente modificable y adaptable a las necesidades del usuario, cualidad que ha logrado convertir al ordenador en un elemento valioso para las personas con discapacidad, que no encontrarán en otras 
máquinas tanta facilidad para la adaptación. (Minusval Especial Discapacidad y Nuevas Tecnologías. Junio 2002)

Fiabilidad y Validez:

La batería cuenta con una aceptable validez y fiabilidad, así como con abundantes datos normativos. (Minusval Especial Daño Cerebral. Diciembre 2002)

Después de analizar las imágenes y valores que son percibidos como inherentes a las técnicas y aparatos tecnológicos, pasemos ahora a examinar aquellas imágenes positivas percibidas en el uso o interacción con la tecnología.

Facilitar:

(...) ayudas técnicas, herramientas y software de libre disposición para facilitar el acceso a Internet y el uso de ordenadores personales por parte de personas mayores y con discapacidad. (Minusval № 157. Mayo - Junio 2006)

Integración:

En un primer avance de conclusiones es preciso asumir que las nuevas tecnologías son un medio de integración social, y un mecanismo de integración sociolaboral y que constituyen una tecnología beligerante para disminuir diferencias. (Minusval № 132. Enero - Febrero 2002)

Apoyo:

Todas las personas con discapacidad que no puedan valerse por sí mismas recibirán ayudas como teleasistencia (...) (Minusval № 158. Julio - Agosto 2006) 
Independencia:

Yo estoy convencido que las nuevas tecnologías ayudan a las personas a ser independientes. (Minusval № 138. Enero - Febrero 2003)

Avance:

Esta casa representa un avance extraordinario sobre todo para las personas que tienen serias dificultades para realizar actividades de la vida diaria en el hogar. La transformación real de una vivienda normal en una casa accesible para una persona con discapacidades resulta menos cara de lo que en principio pudiera suponerse (...) (Minusval № 137. Noviembre - Diciembre 2002)

Mejora:

Los marcadores de idioma mejoran la legibilidad de la Web para todo el mundo, incluso para aquéllos con discapacidades de aprendizaje, cognitivas $\bigcirc$ auditivas. (Minusval Especial Discapacidad y Nuevas Tecnologías. Junio 2002)

Útil:

Doctor MMS permite el diagnóstico remoto de pacientes que se encuentran en su domicilio mediante la combinación de la telefonía móvil, la fotografía digital e Internet, por lo que resulta de especial utilidad para personas con movilidad reducida. (Minusval № 158. Julio - Agosto 2006)

Necesario:

La dismetría ocasionada pude compensarla con un zapato de tacón, normal, de unos $7 \mathrm{cms}$ del que no puedo prescindir. (Minusval № 134. Mayo - Junio 2002) 
Parte II. Aplicación de un modelo de cultura científico-tecnológica en las personas con discapacidad

Oportunidad:

(...) las telecomunicaciones (...) ofrecen oportunidades de formación y empleo. (Minusval № 137. Noviembre - Diciembre 2002)

Calidad de Vida:

La sociedad de la información y las nuevas tecnologías son hoy instrumentos imprescindibles para el desarrollo humano y para obtener una mejor calidad de vida. (Minusval № 131. Noviembre - Diciembre 2001)

Comunicación:

Por otra parte, está Internet que ha aumentado las posibilidades de comunicación para personas ciegas y sordas o con capacidad motora reducida. (Minusval № 143. Enero - Febrero 2004)

Beneficio:

La integración de tecnología en el hogar a través de soluciones domóticas aporta múltiples beneficios a las personas con discapacidad... (Minusval № 158. Julio - Agosto 2006)

Esperanza:

Por ello, resulta obligada una colaboración entre la neuropsicología y los especialistas en el desarrollo de sistemas informáticos y ayudas técnicas para personas con discapacidad. Así, junto a los ya existentes sistemas aumentativos de comunicación o programas de rehabilitación cognitiva con soporte informático se está empezando a desarrollar toda una gama de dispositivos tecnológicos que amplía de forma muy 
notable las posibilidades de intervención. (Minusval Especial Daño Cerebral. Diciembre 2002)

Seguridad:

El servicio de teleasistencia se articula a través de componentes tecnológicos y personales, que proporcionan a los usuarios la seguridad de una respuesta inmediata ante cualquier emergencia y previene eficazmente las sensaciones de inseguridad, soledad y aislamiento. (Minusval Especial Agosto 2005)

Sencillez:

El teclado Bluekey, desarrollado por el Centro de Investigación, Desarrollo y Aplicaciones Tiflotécnicas de la ONCE (CIDAT), permite el acceso de personas con problemas de visión a teléfonos móviles y agendas electrónicas. El dispositivo, que se caracteriza por su sencillez de uso, está equipado con ocho puntos, teclas de control y joystick y utiliza el sistema braille. (Minusval № 150. Marzo - Abril 2005)

Ventaja:

Las personas con discapacidad han conocido las ventajas de las nuevas tecnologías y en muchos casos se han adelantado al resto de la población (...) (Minusval Especial Discapacidad y Nuevas Tecnologías. Junio 2002)

Comodidad:

(...) "hogar inteligente", un lugar donde el confort, el ahorro de tiempo y la interacción desde cualquier lugar entre el ser humano y los aparatos que le rodean son los protagonistas. (Minusval № 142. Octubre - Diciembre 2003) 
Parte II. Aplicación de un modelo de cultura científico-tecnológica en las personas con discapacidad

Igualdad:

(...) pensando que las Nuevas Tecnologías son el elemento fundamental para reducir la diferencia y lograr la equiparación de oportunidades. (Minusval № 130. Septiembre - Octubre 2001)

Cambio:

El formador no sólo cumple una función de carácter pedagógico, informando, orientando y resolviendo dudas, sino que también pretende despertar el interés del alumno, mostrándole cómo Internet puede cambiar su vida. (Minusval № 136. Septiembre Octubre 2002)

Solución:

(...) el acceso a las nuevas tecnologías y, en especial, a la informática y a Internet, ha impulsado el desarrollo de soluciones que resuelven las carencias que padece este colectivo (...) (Minusval № 147. Septiembre - Octubre 2004)

Importancia:

Atendiendo a la importancia de estas tecnologías, los ministerios de Trabajo y Asuntos Sociales, a través del IMSERSO, y de Ciencia y Tecnología, junto con el Comité Español de Representantes de Minusválidos (CERMI) han promovido la elaboración del Libro Blanco de I+D+I al servicio de las personas con discapacidad y de las personas mayores. (Minusval № 139. Marzo - Mayo 2003)

Confianza:

El neuropsicólogo experto debe observar los datos y la ejecución de las tareas que los pacientes realizan y de ellos inferir un juicio clínico; el ordenador facilita ésta tarea y la hace más confiable. (Minusval Especial Daño Cerebral. Diciembre 2002) 
Interesante:

Internet me ha parecido muy interesante porque puedes encontrar muchas cosas (trabajo, noticias, amigos...) (...) (Minusval № 136. Septiembre - Octubre 2002)

Bienestar:

En general, existe un gran desconocimiento de las prestaciones domóticas, de sus posibles aplicaciones y de sus posibilidades para conseguir un aumento del bienestar, lo que se ha empezado a llamar "Domótica Asistencial". (Minusval № 158. Julio - Agosto 2006)

Positivo:

(...) entre las facetas de la vida cotidiana de las personas con discapacidad y mayores consultadas y sobre las cuales se estima pueda tener influencia el uso del móvil, siempre se encuentra que éste ejerce un efecto positivo (...) (Minusval № 132. Enero Febrero 2002)

Favorecer:

Los avances tecnológicos permiten y favorecen estas ayudas, como el DVD o el subtitulado en teletexto, que pueden ayudar a otros colectivos. (Minusval № 135. Julio - Agosto 2002)

Innovación:

Proyectos como WAI (Accesibilidad a la red), INCLUDE (Inclusión de Personas con Discapacidad y Mayores en la Telemática), y la acción COST 219 "Telecomunicaciones para Todos" han proporcionado nuevos datos y enfoques innovadores. (Minusval № 133. Marzo - Abril 2002) 
Parte II. Aplicación de un modelo de cultura científico-tecnológica en las personas con discapacidad

Lúdico:

La investigación formal en los iMac de Apple es un ejemplo de la intención de convertir el ordenador en un objeto más familiar, lúdico y coloquial (...) (Minusval № 133. Marzo - Abril 2002)

Respeto:

AidCat/IBV es una aplicación Web de navegación fácil y respetuosa con las pautas de accesibilidad a Internet. (Minusval Dossier Proyecto EASTIN. Septiembre - Octubre 2005)

Aceptación:

(...) nuevas tecnologías "asequibles, adaptadas, adecuadas, aceptadas y accesibles" (Minusval № 132. Enero - Febrero 2002)

Alivio:

El prototipo diseñado por el Instituto de Biomecánica de la Comunidad Valenciana en colaboración con la Dirección General de Integración Social de Discapacitados de la Generalitat Valenciana, único en el mundo, emula la forma tradicional con una parte superior dispuesta para que estribe en ella el codo, y un agarradero en su parte media que alivia las dificultades para caminar. (Minusval № 138. Enero - Febrero 2003)

Equilibrio:

En el ámbito concreto de la comunicación se hacía preciso conocer el "estado del arte" de aquellas tecnologías, productos y servicios que, directa $\circ$ indirectamente relacionados con las telecomunicaciones, intervienen o se estiman necesarios para un desenvolvimiento eficaz y equilibrado de la vida de las personas 
con discapacidad y mayores. (Minusval № 132. Enero - Febrero 2002)

Cercanía:

El desarrollo de una nueva telemedicina más cercana al ciudadano y más práctica donde las personas de más alto riesgo (crónicos, postoperados), y los que precisan supervisión continua como las embarazadas, sean monitorizadas a distancia con procedimientos prácticamente autónomos, independizando o eliminando la simultaneidad paciente-enfermo, es una de las soluciones de la telefonía móvil (...) (Minusval № 132. Enero Febrero 2002)

Tranquilidad:

Efectos del teléfono móvil sobre aspectos cotidianos. (...) tranquilidad (...) (Minusval № 132. Enero - Febrero 2002)

Variedad:

(...) esta interesante web que amplía la oferta existente en Internet sobre recursos especializados en la adecuación del entorno (...) (Minusval № 151. Mayo - Junio 2005) 
Parte II. Aplicación de un modelo de cultura científico-tecnológica en las personas con discapacidad

\subsubsection{Negativos}

En menor medida que las imágenes positivas, pero también en un número considerable, encontramos en la revista valores negativos asociados a la tecnología. En 189 ocasiones se refleja una imagen y/o valor de alguna técnica o aparato tecnológico como perjudicial.

Hemos agrupado estas visiones en 25 tipos, como vemos en la siguiente tabla:

\begin{tabular}{lc}
\hline Imágenes y Valores Reconocidos Negativos & \\
\hline Total & 189 \\
Exclusión & $26,5 \%$ \\
Brecha & $11,6 \%$ \\
Dificultad & $11,6 \%$ \\
Problema & $11,1 \%$ \\
Inadecuado & $7,9 \%$ \\
Caro & $6,3 \%$ \\
Ineficiencia & $4,2 \%$ \\
Rechazo & $3,7 \%$ \\
Riesgo & $3,2 \%$ \\
Incompleto & $2,1 \%$ \\
Dependencia & $1,6 \%$ \\
Complejidad & $1,1 \%$ \\
Inseguridad & $1,1 \%$ \\
Nocivo & $1,1 \%$ \\
Obsoleto & $1,1 \%$ \\
Estresante & $1,1 \%$ \\
Desigualdad & $0,5 \%$ \\
Desventaja & $0,5 \%$ \\
Exceso & $0,5 \%$ \\
Incompatibilidad & $0,5 \%$ \\
Injusto & $0,5 \%$ \\
Insuficiencia & $0,5 \%$ \\
Miedo & $0,5 \%$ \\
Molestia & $0,5 \%$ \\
Sedentarismo & $0,5 \%$ \\
\hline
\end{tabular}

Tabla 6.2 Imágenes y valores negativos

Llama la atención que después de haber visto que dentro de las imágenes positivas de la tecnología más mencionadas aparece la visión de elemento integrador y clave para lograr y afianzar la independencia de las personas con discapacidad en la sociedad, las características 
negativas encontradas más relevantes sean las de "Exclusión" y "Brecha", es decir, la idea de la tecnología como un elemento segregador, de discriminación dentro de la sociedad. Por ejemplo,

La jornada pretende acercar la Red a aquellos colectivos más desconectados con la Sociedad de la Información, como el de personas con discapacidad, fomentando su participación y el compromiso social para concienciar de sus ventajas y reducir en lo posible lo que viene denominándose como "brecha digital". (Minusval № 152. Julio - Agosto 2005)

... colectivos en riesgo de exclusión digital: personas mayores, con discapacidad e inmigrantes y amas de casa. (Minusval № 155. Enero Febrero 2006)

Este tipo de comunicaciones, basadas casi únicamente en la telefonía móvil, ha dejado al margen a un importante colectivo de posibles usuarios integrado por las personas sordas. (Minusval Especial Discapacidad y Nuevas Tecnologías. Junio 2002)

Hemos agrupado las imágenes y valores negativos de la misma manera que las positivas, según fueran percibidas como propias del aparato o técnica o fueran resultado de la interacción externa con el usuario.

Las imágenes vistas como propias son las siguientes:

Inadecuado:

Aunque la mayoría de los desniveles en el exterior se resuelven con rampas, éstas están mal diseñadas. (Minusval № 134. Mayo - Junio 2002) 
Parte II. Aplicación de un modelo de cultura científico-tecnológica en las personas con discapacidad

Ineficiencia:

El teletexto, que sería uno de los elementos claves para la supresión de barreras de comunicación, no funciona como debería... (Minusval Especial La Accesibilidad. Abril 2004)

Incompleto:

(...) con pocas prestaciones en la actualidad (Teléfono de Textos.) (Minusval № 134. Mayo - Junio 2002)

Complejidad:

Cambios sencillos como el de un grifo tradicional por un monomando puede representar una dificultad para adaptarse a un nuevo modo de utilizar el dispositivo y cambios más complejos que requieran de mandos a distancia, manipulación de aparatos electrónicos o similares no son asimilados con facilidad. (Minusval Especial La Accesibilidad. Abril 2004)

Insuficiencia:

(...) ni las prótesis ni las ayudas técnicas más sofisticadas, ni los mejores profesionales, serán nunca suficientes (...) (Minusval Especial Atención Temprana. Marzo 2003)

Caro:

(...) el material deportivo: sillas de ruedas, prótesis tienen un coste elevado por su composición y sofisticación. (Minusval № 135. Julio - Agosto 2002)

Obsoleto:

Sin embargo, la rápida evolución de la informática hizo que los dispositivos y programas desarrollados quedaran obsoletos en poco tiempo, condenando a las personas con discapacidad a 
utilizar ordenadores "prehistóricos" hasta que resultaban absolutamente no operativos. (Minusval Especial Discapacidad y Nuevas Tecnologías. Junio 2002)

Por otro lado, al igual que con las positivas, también se distinguen imágenes negativas asociadas a la interrelación con el usuario y el entorno.

Exclusión:

Este tipo de comunicaciones, basadas casi únicamente en la telefonía móvil, ha dejado al margen a un importante colectivo de posibles usuarios integrado por las personas sordas. (Minusval Especial Discapacidad y Nuevas Tecnologías. Junio 2002)

Brecha:

El curso, que se celebra entre el 19 de octubre de 2005 y el 19 de mayo de 2006, ofrece una formación especializada en el desarrollo de tecnologías accesibles a las personas con discapacidad, partiendo de que el desconocimiento existente a nivel formativo en este campo provoca el diseño de servicios que incrementan la "brecha digital". (Minusval № 153. Septiembre Octubre 2005)

Dificultad:

Por ejemplo, para los ciegos y las personas con discapacidad visual es muy difícil, o imposible, acceder a muchos documentos en línea, del tipo de las páginas web, con el tipo de navegadores (con los lectores de pantallas, por ejemplo) y otros dispositivos de ayuda que normalmente usan. (Minusval № 131. Noviembre Diciembre 2001) 
Parte II. Aplicación de un modelo de cultura científico-tecnológica en las personas con discapacidad

Problema:

El plan Wisdom va a investigar los problemas que tienen los sordos con los teléfonos móviles y la aplicación de las más avanzadas técnicas para desarrollar nuevos métodos de interacción. (Minusval № 130. Septiembre - Octubre 2001)

Rechazo:

(...) la [SILLA DE RUEDAS] eléctrica no me gusta" (Minusval № 153. Septiembre - Octubre 2005)

Riesgo:

(...) porque si se sube una silla de ruedas sin anclar y el coche frena se convierte en un peligro para todos los viajeros y para él mismo. (Minusval № 143. Enero - Febrero 2004)

Dependencia:

Los que tenemos una discapacidad por sufrir un accidente, en lo primero que pensamos es en la cantidad de cosas que ya no vamos a poder hacer. Con esta falta de libertad que sientes por estar en una silla de ruedas (...) (Minusval № 132. Enero Febrero 2002)

Inseguridad:

(...) mal uso de los datos personales por el sector de la informática. (Minusval Especial La Discapacidad en Europa. Mayo 2003)

Nocivo:

La compatibilidad debe también ser probada para evitar que ciertos productos utilizados por las personas con discapacidad 
tengan efectos nocivos -interferencias electromagnéticas de los teléfonos móviles y de los audífonos, por ejemplo. (Minusval Especial La Discapacidad en Europa. Mayo 2003)

Estresante:

El teletexto, que sería uno de los elementos claves para la supresión de barreras de comunicación, no funciona como debería, llegando en ocasiones a ser tan estresante como leer un libro al que tu sobrinito ha arrancado una hoja por aquí, parte de otra por allá. (Minusval Especial La Accesibilidad. Abril 2004)

Desventaja:

Las personas que padecen algún tipo de deficiencia visual, ya sea total o parcial, se encuentran en desventaja a la hora de interactuar con los medios informáticos, cuando pretenden acceder, y sobre todo, tratar, la información deseada. (Minusval Especial Discapacidad y Nuevas Tecnologías. Junio 2002)

Exceso:

(...) la cada vez más abrumadora cantidad de información, recursos y servicios que sobre discapacidad dispone Internet. (Minusval № 131. Noviembre - Diciembre 2001)

Incompatibilidad:

Estas tecnologías abarcan un espectro tan amplio de campos tecnológicos y científicos que las aplicaciones inadecuadas están causando más de una brecha digital, entre otras razones, por su dificultad de uso, a causa de la carencia de criterios de diseño y por la incompatibilidad entre dispositivos. (Minusval Especial 25 años del IMSERSO. Diciembre 2003) 
Parte II. Aplicación de un modelo de cultura científico-tecnológica en las personas con discapacidad

Miedo:

(...) que los nuevos usuarios pierdan el miedo a esta tecnología y la incorporen a su vida cotidiana. (Minusval № 136. Septiembre Octubre 2002)

Molestia:

(...) situaciones de malestar: molestias de aparatos ortopédicos, dolor, fiebre, etc. (Minusval № 157. Mayo - Junio 2006)

Sedentarismo:

Hoy en día ciertos factores influyen decisivamente sobre el estado de salud de los individuos (...) [favorecen] el sedentarismo (televisor, vídeo casero...) (Minusval № 131. Noviembre Diciembre 2001)

Desigualdad e Injusto:

La eliminación de barreras arquitectónicas ha sido uno de los caballos de batalla contra la desigualdad injusta que han sufrido históricamente los discapacitados. (Minusval № 130. Septiembre Octubre 2001) 


\subsubsection{Deseados}

Además de las imágenes y valores que se perciben en el texto como fácilmente identificables en la realidad, hay otros que se manifiestan como deseadas, es decir, se expresa el deseo que de estas características formen parte de las técnicas y aparatos tecnológicos. Por supuesto, todas contienen una carga valorativa positiva, como vemos en la tabla 6.3, pero se diferencian con las imágenes y valores positivos en el hecho de que no son reconocidas como presentes en la actualidad. Se caracterizan por manifestarse como un deseo subjetivo o un "deber ser".

\begin{tabular}{lr}
\hline Imágenes y Valores Deseados & \\
\hline Total & 128 \\
Accesibilidad & $51,6 \%$ \\
Brindar Facilidades & $7,0 \%$ \\
Sencillez & $7,0 \%$ \\
Igualdad & $5,5 \%$ \\
Adecuación & $3,9 \%$ \\
Independencia & $3,9 \%$ \\
Seguridad & $3,1 \%$ \\
Integración & $3,1 \%$ \\
Agradable & $1,6 \%$ \\
Asequible & $1,6 \%$ \\
Barato & $1,6 \%$ \\
Comodidad & $1,6 \%$ \\
Compatibilidad & $1,6 \%$ \\
Útil & $1,6 \%$ \\
Eficiencia & $1,6 \%$ \\
Confianza & $0,8 \%$ \\
Inteligencia & $0,8 \%$ \\
Mejora & $0,8 \%$ \\
Natural & $0,8 \%$ \\
Versatilidad & $0,8 \%$ \\
\hline
\end{tabular}

Tabla 6.3 Imágenes y valores deseados

A pesar de ser el principal valor positivo reconocido como presente en las tecnologías, las alusiones a la "Accesibilidad" como algo deseado nos hablan de una necesidad no cubierta aún para las personas con discapacidad. 
Parte II. Aplicación de un modelo de cultura científico-tecnológica en las personas con discapacidad

Debe instarse a las organizaciones que reciban fondos públicos de las instituciones europeas o los Estados miembros a hacer que sus sitios web sean accesibles. (Minusval № 131. Noviembre - Diciembre 2001)

El comité Español de representantes de Minusválidos (CERMI) ha solicitado a la Federación de Distribuidores Cinematográficos (FEDICINE) que todos los productos audiovisuales que distribuye cine, video o DVD, sean accesibles. (Minusval № 139. Marzo - Mayo 2003)

Favorecer la accesibilidad en los autobuses de las líneas regulares de carácter público urbano durante 2006, y eliminar las barreras para las personas con discapacidad fue el objetivo del acuerdo firmado. (Minusval № 157. Mayo - Junio 2006)

Desde este punto de vista, este acuerdo colaborará para concienciar a los fabricantes de teléfonos móviles sobre la necesidad de incorporar el concepto de "Diseño para todos" en el desarrollo de los nuevos dispositivos, de manera que se mejore su accesibilidad y usabilidad. (Minusval № 156. Marzo - Abril 2006)

Revisemos algunos ejemplos de las imágenes y valores deseados para las tecnologías, además de la accesibilidad:

Sencillez:

Los servicios domóticos deben ser accesibles para todos los usuarios, y su utilización debe resultar eficiente y fácil de aprender. (Minusval № 158. Julio - Agosto 2006)

Adecuación:

(...) diseñar interfaces enfocadas a la navegación autónoma de una silla de ruedas de tracción con el fin de que dichas interfaces sean más adecuadas (...) (Minusval Especial Discapacidad y Nuevas Tecnologías. Junio 2002) 
Agradable:

(...) necesitan que esos aparatos estén diseñados de manera tan atrayente y aceptable como sea posible. (Minusval Especial La Discapacidad en Europa. Mayo 2003)

Compatibilidad:

La compatibilidad de los productos que algunas personas con discapacidad necesitan utilizar junto con otros debe estar garantizada, de manera que puedan funcionar en armonía; por ejemplo, el terminal de un cajero automático bancario debe poder ser fácilmente conectado a una tablilla en braille. (Minusval Especial La Discapacidad en Europa. Mayo 2003)

Eficiencia:

Los servicios domóticos deben ser accesibles para todos los usuarios, y su utilización debe resultar eficiente y fácil de aprender. (Minusval № 158. Julio - Agosto 2006)

Inteligencia:

Ubicuidad, transparencia e inteligencia son las tres propiedades básicas de los ambientes inteligentes: ubicuidad para encontrarlos en el punto donde esté la persona, transparencia para pasar inadvertidos en el medio físico e inteligencia para adaptarse a las preferencias de cada persona. (Minusval № 158. Julio - Agosto 2006)

Asequible:

(...) la importancia que tiene que las nuevas tecnologías sean accesibles y asequibles para la inmensa mayoría de los ciudadanos. (Minusval № 141. Agosto - Septiembre 2003) 
Parte II. Aplicación de un modelo de cultura científico-tecnológica en las personas con discapacidad

Barato:

Además, la interfaz ha de ser de bajo coste económico (...) (Minusval Especial Discapacidad y Nuevas Tecnologías. Junio 2002)

Brindar Facilidades:

Fomentar la implantación de tecnologías que faciliten el acceso de las personas con discapacidad a los servicios de la Sociedad de la Información (...) (Minusval № 151. Mayo - Junio 2005)

lgualdad:

Aboga, por ejemplo, porque una tecnología existente (un teléfono móvil) sea utilizable por todos (...) (Minusval Especial La Accesibilidad. Abril 2004)

Independencia:

Las Nuevas Tecnologías, especialmente las relacionadas con la Informática y las Comunicaciones, deben contribuir a una mayor autonomía de las personas con discapacidad. (Minusval Especial Discapacidad y Nuevas Tecnologías. Junio 2002)

Seguridad:

Las mujeres con discapacidad deben poder usar los servicios electrónicos con seguridad y confort. (Minusval № 137. Noviembre - Diciembre 2002)

Integración:

(...) asegurar que los materiales multimedia y el uso de TIC en la educación no creen nuevas barreras contra la integración de 
estudiantes con discapacidad. (Minusval № 138. Enero - Febrero 2003)

Comodidad:

Nuestra relación con la máquina o los sistemas debe hacerse de forma agradable y confortable. (Minusval № 158. Julio - Agosto 2006)

Útil:

Lograr que la tecnología informática y los recursos sean útiles para todos los colectivos activos en la sociedad, entre éstos, las personas con discapacidad (...) (Minusval № 130. Septiembre Octubre 2001)

Mejora:

(...) conseguir que las nuevas tecnologías permitan superar las condiciones de discapacidad y pobreza de estos colectivos. (Minusval № 149. Enero - Febrero 2005)

Versatilidad:

Utilidad, eficiencia y flexibilidad. Una premisa irrenunciable, e independiente de adyacentes cuestiones de mercado, es que los sistemas de hogar digital mejoren la calidad de vida de sus usuarios. (Minusval № 158. Julio - Agosto 2006)

Confianza y Natural:

Cuando consigamos que la tecnología cotidiana esté perfectamente integrada en el entorno: volviéndose invisible para el usuario, con una infraestructura de comunicaciones móvil/fijo 
Parte II. Aplicación de un modelo de cultura científico-tecnológica en las personas con discapacidad

interactiva y sin transiciones; cuando dispongamos de sistemas fiables y estables e interfaces naturales, cuando los espacios sean inter operables y sean interfaces en si mismos (espacios inteligentes), alcanzaremos una fácil comunicación humana (...) (Minusval № 158. Julio - Agosto 2006) 


\subsection{Aparatos tecnológicos y técnicas}

Como ya hemos señalado en varias ocasiones, identificamos la presencia de ciertas técnicas y aparatos tecnológicos. De los 90 términos utilizados ${ }^{20}$ queremos destacar la presencia significativa de los 20 con más frecuencia de aparición (Tabla 6.4).

\begin{tabular}{lc}
\hline 20 primeros aparatos y técnicas & \\
\hline Total (90) & 4540 \\
WEB & $16,1 \%$ \\
INTERNET & $11,8 \%$ \\
INFORMÁTICA & $9,8 \%$ \\
SILLA & $6,5 \%$ \\
TELEFONÍA & $6,3 \%$ \\
RUEDA & $6,3 \%$ \\
ELECTRÓNICA & $5,4 \%$ \\
ORDENADOR & $5,3 \%$ \\
DIGITAL & $4,2 \%$ \\
MÓVIL & $3,9 \%$ \\
VEHÍCULO & $3,5 \%$ \\
AUTOBÚS & $2,8 \%$ \\
TELECOMUNICACIÓN & $2,6 \%$ \\
TELEASISTENCIA & $2,5 \%$ \\
TECLADO & $2,5 \%$ \\
VIDEO & $2,3 \%$ \\
COMPUTACIÓN & $2,2 \%$ \\
BRAILLE & $2,0 \%$ \\
SOFTWARE & $2,0 \%$ \\
DOMÓTICA & $1,8 \%$ \\
\hline
\end{tabular}

Tabla 6.4 Aparatos y técnicas

El total de frecuencias de la tabla es sobre los 90 aparatos encontrados en el texto. Destacan en los primeros puestos las tecnologías referidas a la Informática, siendo el concepto con más alusiones "Web" con el 16,1\%, seguido por "Internet" (11,8\%) y el propio término "Informática" con un 9,8\%. Vemos que dentro de los veinte conceptos más citados en la revista, también se incluyen "Ordenador" (5,3\%), "Digital" (4,2\%), "Teclado" $(2,5 \%)$ y "Software" (2\%). No consideramos "Computación" al tener sus

${ }^{20}$ Cfr. pp. 116 - 118, en el apartado metodológico del Capítulo 5. 
Parte II. Aplicación de un modelo de cultura científico-tecnológica en las personas con discapacidad

menciones en el texto un significado relativo exclusivamente al verbo computar, sin ninguna conexión con la tecnología informática.

\subsection{Relación entre diferentes grupos tecnológicos con las imágenes y valores asociados a ellas.}

Para poder comprender un poco mejor cómo es la imagen que se proyecta de la tecnología y cuáles son los principales valores vinculados, hemos agrupado los aparatos y técnicas mencionadas en tres grupos: Informática, Telefonía y Tecnologías específicas.

En el primero, Informática, encontramos los aparatos y las técnicas relacionadas con el tratamiento automático de la información mediante ordenadores.

En el grupo Telefonía, hemos juntado los que se vinculan con las comunicaciones telefónicas, ya sean máquinas o servicios brindados a través de la telefonía.

En el tercer conjunto, Tecnologías específicas, tenemos ayudas técnicas, aplicaciones concretas para generar productos que eviten, compensen, mitiguen o neutralicen la deficiencia o la discapacidad.

\subsubsection{Grupo Informática}

\section{A) Positivos}

En este grupo, en un total de 490 ocasiones sus componentes se relacionan con alguna imagen o valor positivo. Como se aprecia en la figura 6.2, Internet es la tecnología que más se asocia a valores positivos, seguida, según el porcentaje, por el Ordenador y la Web. 

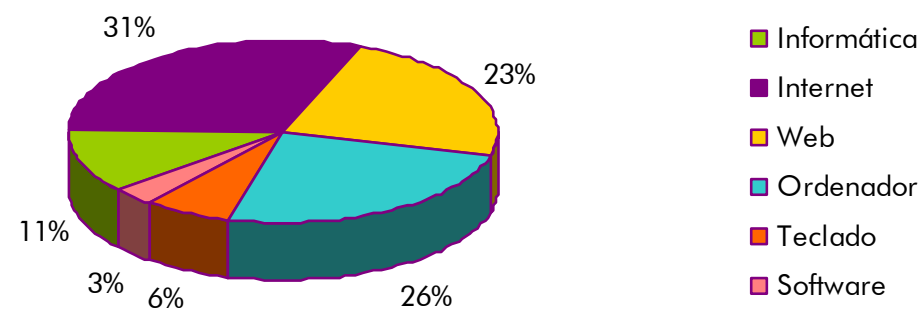

Fig. 6.2 Grupo Informática en relación a imágenes y valores positivos

La imágenes más destacadas con las que se vincula Internet son las de "facilitar", en un 10,7\% de los casos; "integración", con un 8,7\%, y "accesibilidad", 7,4\%.

El ordenador está asociado con la idea de hacer más fácil la vida ("facilitar"), el 14,8\% de las veces que aparece junto a un valor positivo lo hace con este concepto; en segundo lugar se relaciona con la imagen de "apoyo", con un 6,6\%; y con "mejora" y "útil", ambas con un 5,7\%.

Por su parte, la Web, que se refiere fundamentalmente a los sitios Web, aparece conectada principalmente a la "accesibilidad", con un 16,5\% de las 115 referencias positivas; un $8,7 \%$ se asocia a "sencillez" y un 7,8\% a "integración".

Ya con menos alusiones tenemos a la palabra Informática, que se relaciona con "facilitar" y "útil", en ambos casos en el 10,7\% de los casos, y con "avance", con un $8,9 \%$.

El teclado está vinculado positivamente en 31 ocasiones, de las cuales, el 19,4\% hacen referencia a "facilitar" y el 16,1\% a "útil". A "sencillez" y "solución" les corresponde un 9,7\% a cada uno. 
Parte II. Aplicación de un modelo de cultura científico-tecnológica en las personas con discapacidad

Por último, software también se asocia a "facilitar", en este caso en un $17,6 \%$ de las veces. La otra imagen destacable con la tiene conexión es la de "integración".

Es notoria la supremacía de "facilitar" como imagen positiva en este grupo tecnológico.

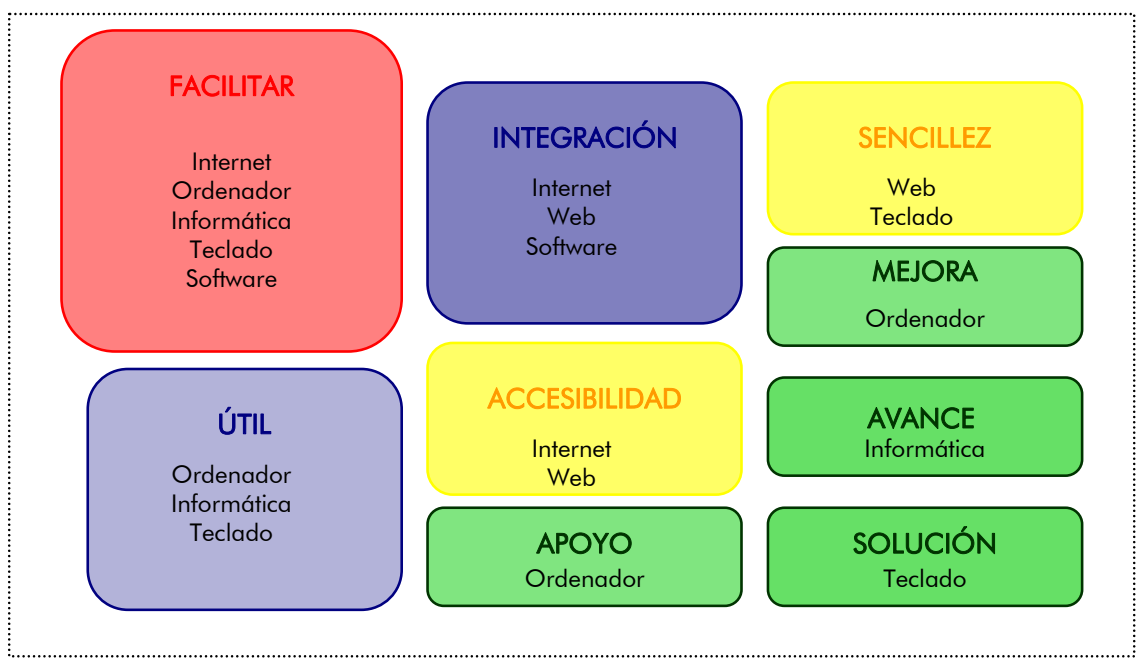

Fig. 6.3 Resumen de Grupo Informática en relación a imágenes y valores positivos

B) Negativos

A la hora de distinguir las imágenes y valores negativos, vemos que el número de referencias es menor que en los casos positivos. Hay un total de 131 co-apariciones entre un aparato tecnológico o una técnica y una imagen o un valor negativo. 


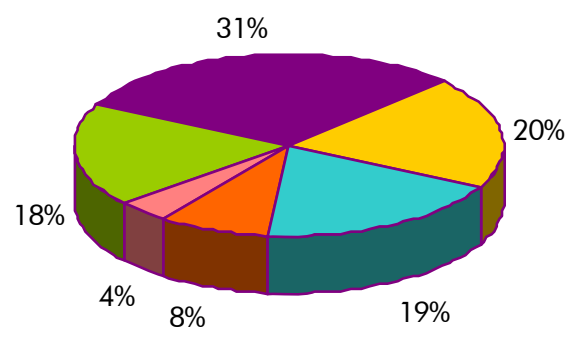
$\square$ Informática
- Internet
$\square$ Web
$\square$ Ordenador
$\square$ Teclado
$\square$ Software

Fig. 6.4 Grupo Informática en relación a imágenes y valores negativos

Al igual que sucede con las imágenes positivas, es Internet la tecnología que más referencias recibe, en este caso con un $31 \%$. De las 40 menciones negativas a Internet, el 32,5\% corresponde a "exclusión" y, con un $17,5 \%$ cada una, observamos la presencia de "brecha" y "dificultad".

La mitad de las alusiones a Web (50\%) con un valor negativo corresponde a "exclusión" y sobresale también la idea de "dificultad" con un 19,2\%.

El ordenador también se vincula con la imagen de "exclusión" en un poco más de la mitad de las menciones (52\%). La siguiente idea con la que se relaciona es la de "brecha".

Asimismo, el término informática, aparece relacionado con "exclusión" en un tercio de las ocasiones (33,3\%) y con "problema" en un $16,7 \%$ de sus alusiones vinculadas con imágenes negativas.

El teclado se asocia tan sólo en 11 ocasiones con una imagen negativa y las más importantes son "ineficiencia" y "problema", ambas con un $27,3 \%$ de los casos. 
Parte II. Aplicación de un modelo de cultura científico-tecnológica en las personas con discapacidad

Finalmente, software muestra en un $40 \%$ de sus menciones con connotación negativa una relación con la imagen predominante en la revista, la de "exclusión".

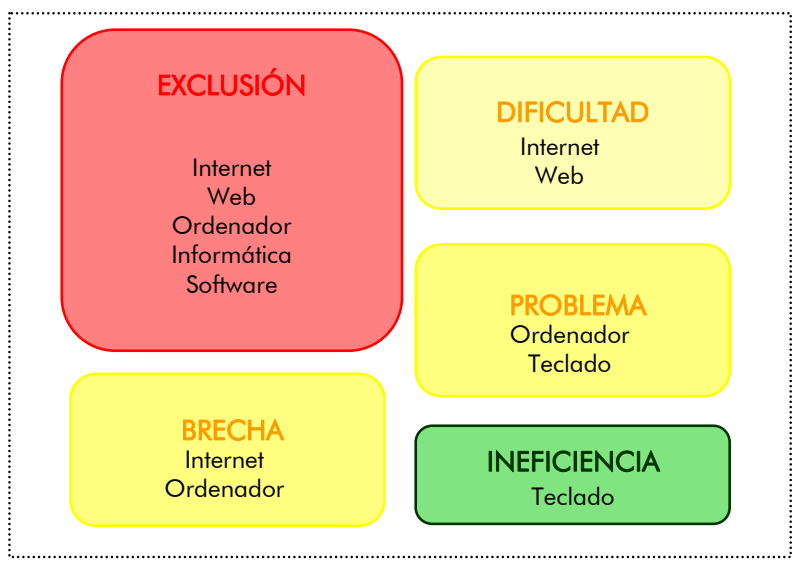

Fig. 6.5 Resumen de Grupo Informática en relación a imágenes y valores negativos

\section{C) Deseados}

Examinemos ahora los valores que se desea que posean las tecnologías informáticas. De las 82 veces en las que se establecen nexos entre ellos, las más importantes vuelven a ser la web, Internet y la informática, como vemos en la siguiente figura.

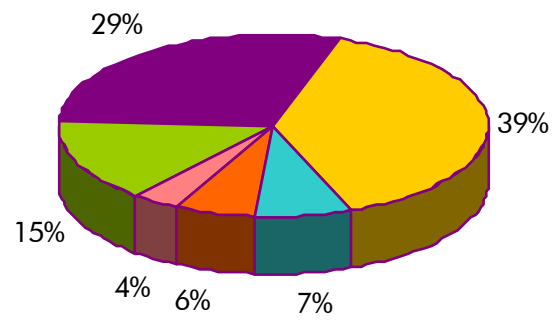
$\square$ Informática
- Internet
$\square$ Web
$\square$ Ordenador
$\square$ Teclado
$\square$ Software

Fig. 6.6 Grupo Informática en relación a imágenes y valores deseados 
El valor deseado con el que más se relacionan las tecnologías informáticas es el de "accesibilidad", web lo hace en un $87,5 \%$ de sus citas, Internet en un $70,8 \%$, informática un $25 \%$, ordenador un $33,3 \%$, teclado un $60 \%$ y software tiene una vinculación de un $66,7 \%$ con este principio.

Destacan también las vinculaciones entre informática e Internet con "igualdad" (16,7\% y $8,3 \%$, respectivamente) y las de web y ordenador con "brindar facilidades" (6,3\% y 33,3\% de sus correspondientes menciones).

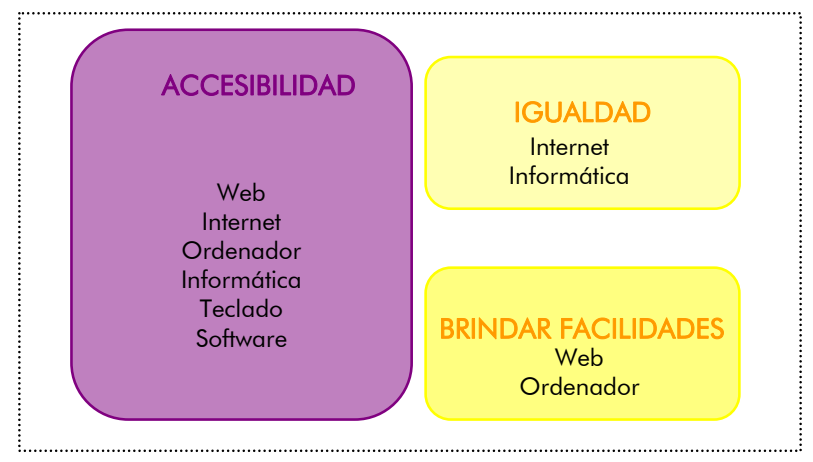

Fig. 6.7 Resumen de Grupo Informática en relación a imágenes y valores deseados 
Parte II. Aplicación de un modelo de cultura científico-tecnológica en las personas con discapacidad

\subsubsection{Telefonía}

A) Positivos

De las 223 veces en las que los conceptos integrantes de este grupo se asocian con una imagen o valor positivo, el término que más referencias tiene es, precisamente el que le da nombre al grupo, la Telefonía, con un $41 \%$, como vemos en la figura 6.8 .

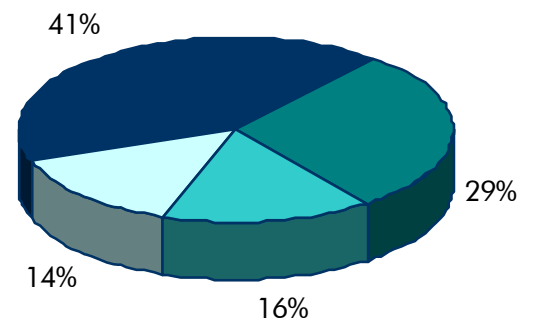

$$
\begin{aligned}
& \square \text { Telefonía } \\
& \square \text { Móvil } \\
& \square \text { Telecomunicación } \\
& \square \text { Teleasistencia }
\end{aligned}
$$

Fig. 6.8 Grupo Telefonía en relación a imágenes y valores positivos

Vinculadas con Telefonía, las imágenes más importantes que aparecen en la revista Minusval son "facilitar" y "útil" con un $8,7 \%$ cada una y "accesibilidad", con un 7,6\% de las menciones positivas.

Con la palabra Móvil nos encontramos nuevamente la idea de "facilitar", con un $10,8 \%$ de las 65 alusiones identificadas en el texto, y seguidamente "sencillez" y "útil", las dos con un 7,7\%.

Por otro lado, surgen nuevos conceptos asociados a Telecomunicación. En un $11,4 \%$ de las 35 ocasiones en las que esta palabra se vincula a una imagen o valor positivo tiene que ver con "independencia". "Calidad de 
vida" y "avance" aparecen asociadas a la telecomunicación con el mismo porcentaje, $8,6 \%$.

Finalmente, Teleasistencia, es representada con las imágenes de "independencia" (19,4\%) y "seguridad" (9,7\%), principalmente.

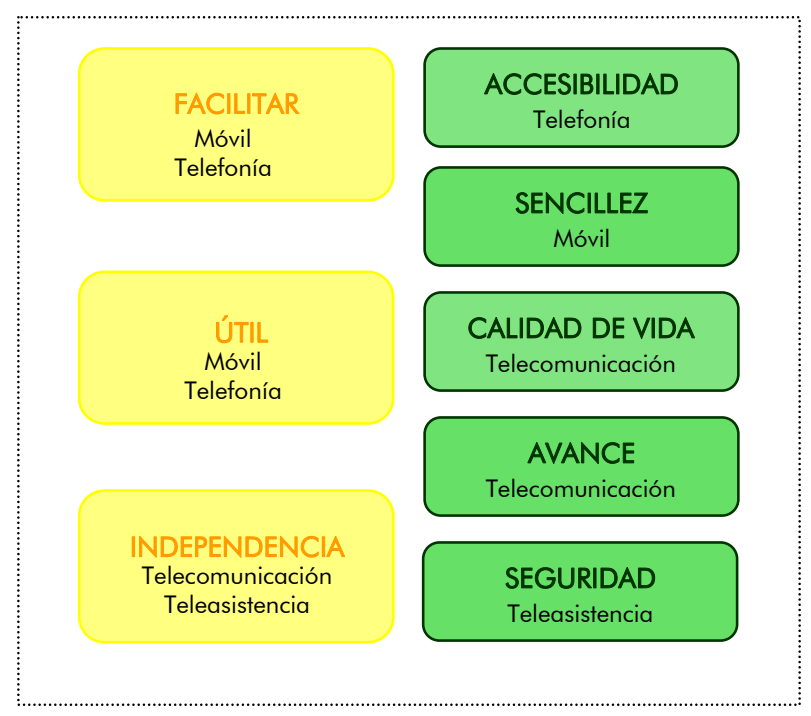

Fig. 6.9 Resumen de Grupo Telefonía en relación a imágenes y valores positivos

B) Negativos

El número de imágenes y valores negativos asociados a la telefonía disminuye notablemente en comparación a los casos positivos. La cantidad que se vincula a aspectos perjudiciales sólo alcanza a 38 . De ellas, es también la palabra Telefonía la que concentra el mayor número (Fig. 6.10). 
Parte II. Aplicación de un modelo de cultura científico-tecnológica en las personas con discapacidad

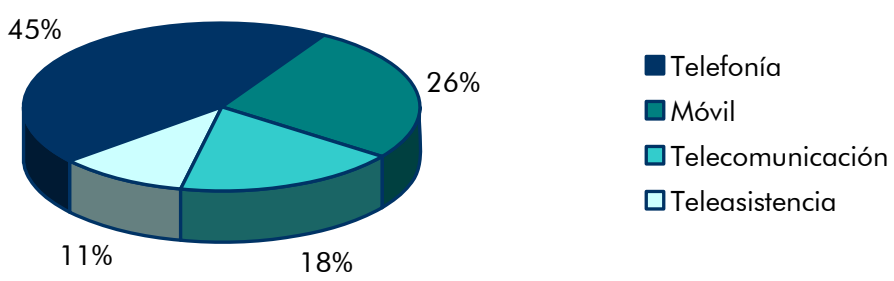

Fig. 6.10 Grupo Telefonía en relación a imágenes y valores negativos

De las 17 alusiones negativas de Telefonía, el 29,4\% se refieren a "exclusión". Con un 17,6\% encontramos "caro" y "dificultad". En cuanto a Móvil vemos que están al mismo nivel las imágenes de "inadecuado", "problema", "caro" y dificultad", todas con un $20 \%$.

Por otra parte, Telecomunicación se relaciona principalmente con "exclusión" (42,9\%) y, luego, con un mismo porcentaje encontramos "brecha", "estresante", "ineficiencia" y "problema" (14,3\%).

Teleasistencia sólo tiene 4 menciones negativas y la mitad se refiere a "exclusión". Las otras imágenes mencionadas son "caro" e "incompleto".

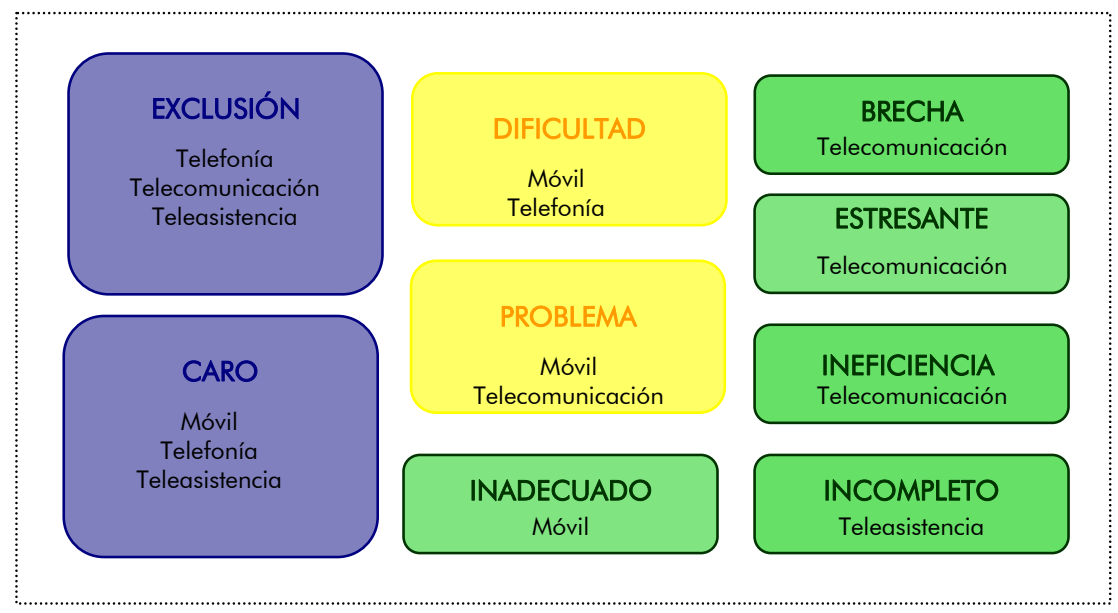

Fig. 6.11 Resumen de Grupo Telefonía en relación a imágenes y valores negativos 
C) Deseados

Al observar la conexión que se establece entre estas tecnologías y las imágenes y valores deseados para ellas, advertimos que Telefonía y Móvil reciben la misma cantidad de alusiones (Fig. 6.12). Las referencias hacia la Telecomunicación son notablemente menos y no existen con respecto a la Teleasistencia.

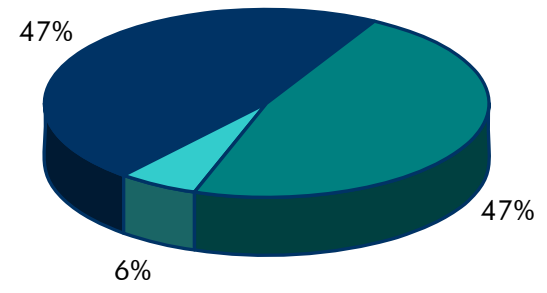

Telefonía

$\square$ Móvil

$\square$ Telecomunicación

$\square$ Teleasistencia

Fig. 6.12 Grupo Telefonía en relación a imágenes y valores deseados

Como señalábamos Telefonía y Móvil tiene el mismo número de menciones de valores deseados y ambas se vinculan, principalmente, con "accesibilidad" (62,5\% y 43,8\% respectivamente) y con "sencillez" (ambas con un 18,8\%). Las dos alusiones a Telecomunicación corresponden a la "accesibilidad".

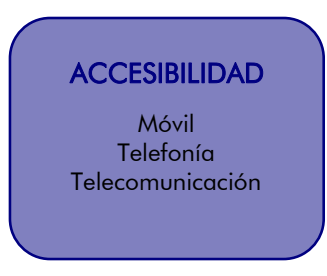

SENCILLEZ

Móvil

Telefonía

Fig. 6.13 Resumen de Grupo Telefonía en relación a imágenes y valores deseados 
Parte II. Aplicación de un modelo de cultura científico-tecnológica en las personas con discapacidad

\subsubsection{Tecnologías específicas}

A) Positivos

De las tecnologías concebidas especialmente para personas con discapacidad se proyecta una imagen positiva en un total de 181 alusiones. Como se advierte en la figura 6.14, son cuatro las tecnologías que tienen un mayor volumen de menciones positivas: la domótica (22\%), la silla de ruedas (20\%), la teleasistencia (17\%) y el braille (14\%).

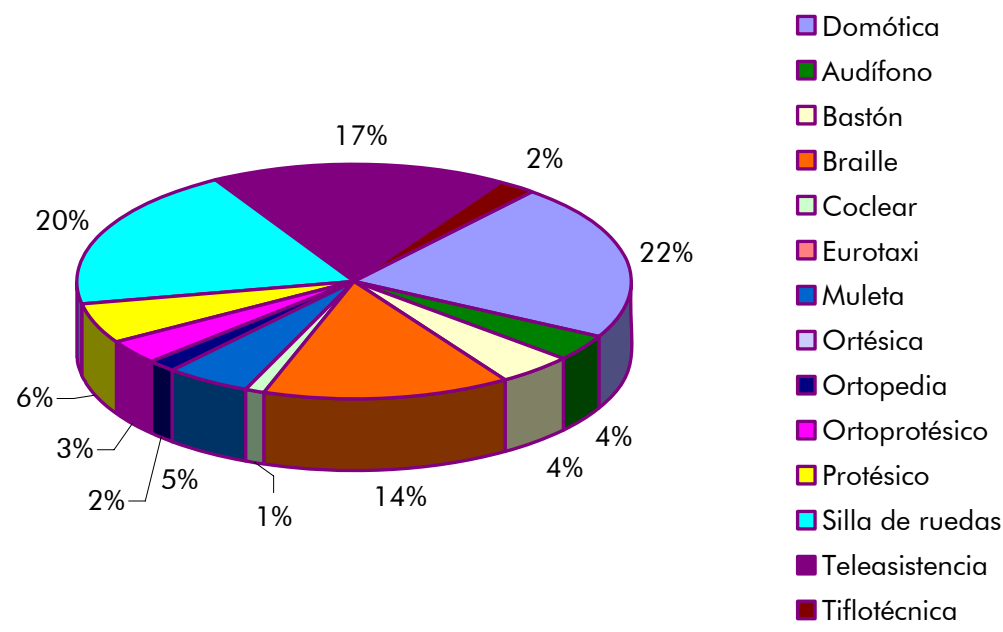

Fig. 6.14 Grupo Tecnologías Específicas en relación a imágenes y valores positivos

La domótica se presenta en 39 ocasiones vinculada a valores positivos, entre los que destacan la "independencia" (15,4\% de las referencias) y "calidad de vida" (12,8\%). Por su parte, la silla de ruedas se asocia a "necesario" en un 19,4\% de las 36 alusiones positivas que recibe, en un $13,9 \%$ a "facilitar" y en un 8,3\% a "independencia". En cambio el braille, de las 26 menciones, la relación con "facilitar" alcanza un 23,1\% y con "útil" llega al 15,4\%. 
El resto de los aparatos o técnicas específicas muestra pocas conexiones con valores positivos. Audífono se asocia con "apoyo" (42,9\%) y con "avance" y "mejora" (28,6\%). Las más importantes en relación al bastón son "independencia" y "necesario" (entre ambas el 50\%); y en cuanto a coclear las dos únicas menciones positivas son para "avance" y "mejora".

Una de cada tres imágenes vinculadas a muleta corresponden a "facilitar" y un $22 \%$ para "seguridad". Tres son las citas positivas en relación a la ortopedia: "apoyo", "comunicación" y "ventaja". Esta última, también está asociada a la ortoprotésica. En cambio, lo simplemente protésico tiene como principales imágenes relacionadas "avance" y "mejora", ambas con un $20 \%$ de las alusiones positivas. La tiflotécnica cuenta con sólo 4 referencias: "accesibilidad", "facilitar", "sencillez" y "útil".

Para terminar esta parte del análisis, debemos decir que eurotaxi y ortésica no muestran ninguna relación con imágenes y valores positivos. 
Parte II. Aplicación de un modelo de cultura científico-tecnológica en las personas con discapacidad

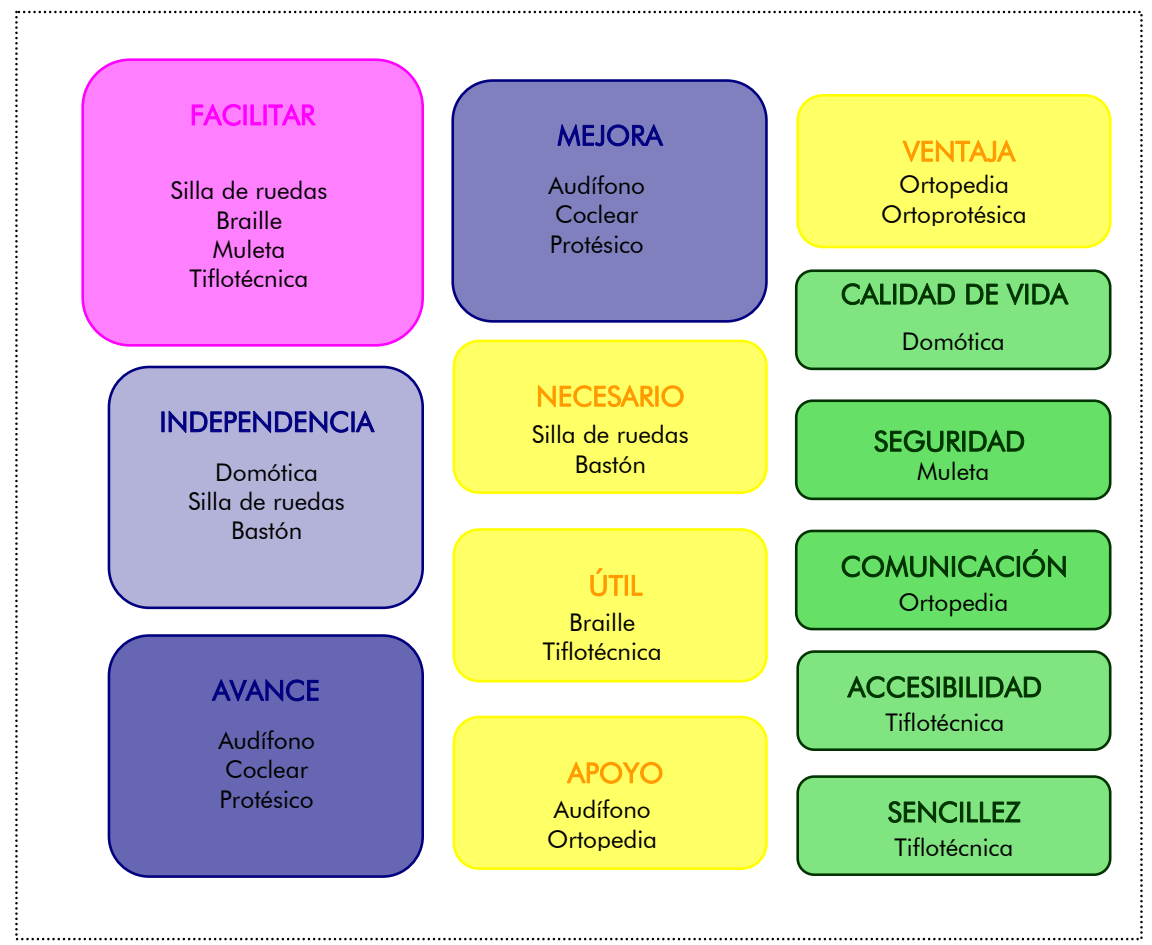

Fig. 6.15 Resumen de Grupo Tecnologías Específicas en relación a imágenes y valores positivos 
B) Negativos

En la revista Minusval se observan muy pocas imágenes o valores negativos en relación a las tecnologías específicas, tan sólo 54 veces en los 37 ejemplares analizados. Sorprende, por lo tanto, la cantidad de referencias a la silla de ruedas, que se lleva el $57 \%$ de las menciones. (Fig. 6.16)

Por otra parte, también se advierte el hecho de que ni muleta, ortésica, ortoprotésica ni tiflotécnica, muestren asociación alguna con valores negativos.

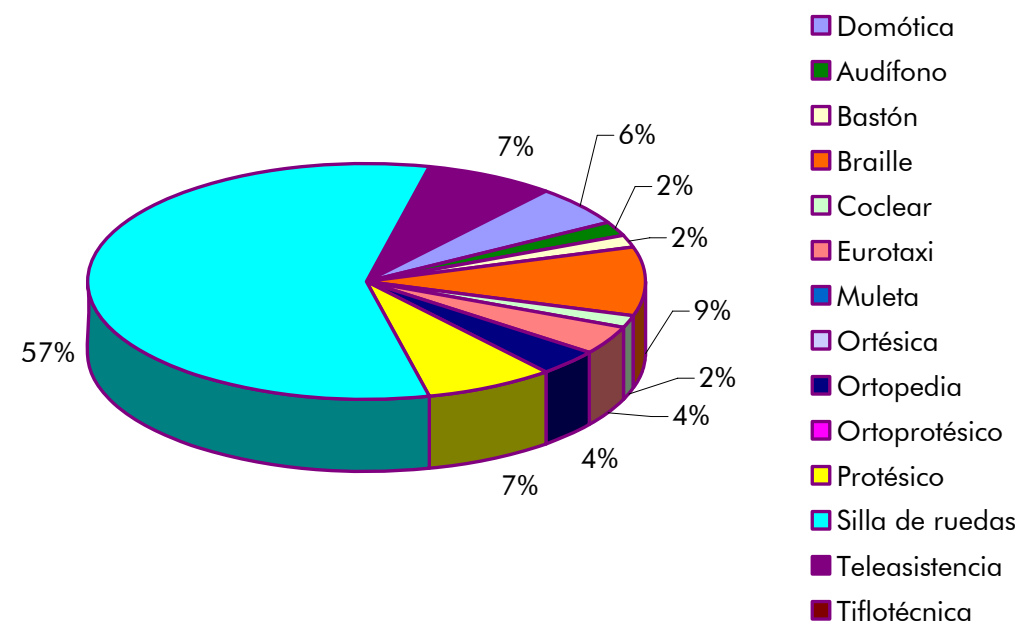

Fig. 6.16 Grupo Tecnologías Específicas en relación a imágenes y valores negativos

Como decíamos, silla de ruedas es la tecnología que mayor número de referencias negativas tiene y no presenta un concentración destacada en ninguna de las alusiones, siendo las más importantes "exclusión" (19,4\%), "inadecuado" (16,1\%) y "dificultad" (12,9\%). 
Parte II. Aplicación de un modelo de cultura científico-tecnológica en las personas con discapacidad

El braille está relacionado a un mismo nivel con "caro", "desventaja", "dificultad", "inadecuado" y "problema".

La domótica se muestra asociada a "brecha", "dificultad" y "exclusión", con una mención cada una. Por su parte, el eurotaxi tiene dos referencias negativas: "caro" y "rechazo".

Protésico cuenta con 4 menciones de las que la mitad se refieren a "caro" y las otras a "insuficiencia" y "problema". En cuanto a la ortopedia sólo se observan dos alusiones, una a "molestia" y otra a "rechazo".

Con una sola cita negativa relacionada con "exclusión" identificamos al bastón, al audífono, con "nocivo", y al término coclear se asocia a "incompleto".

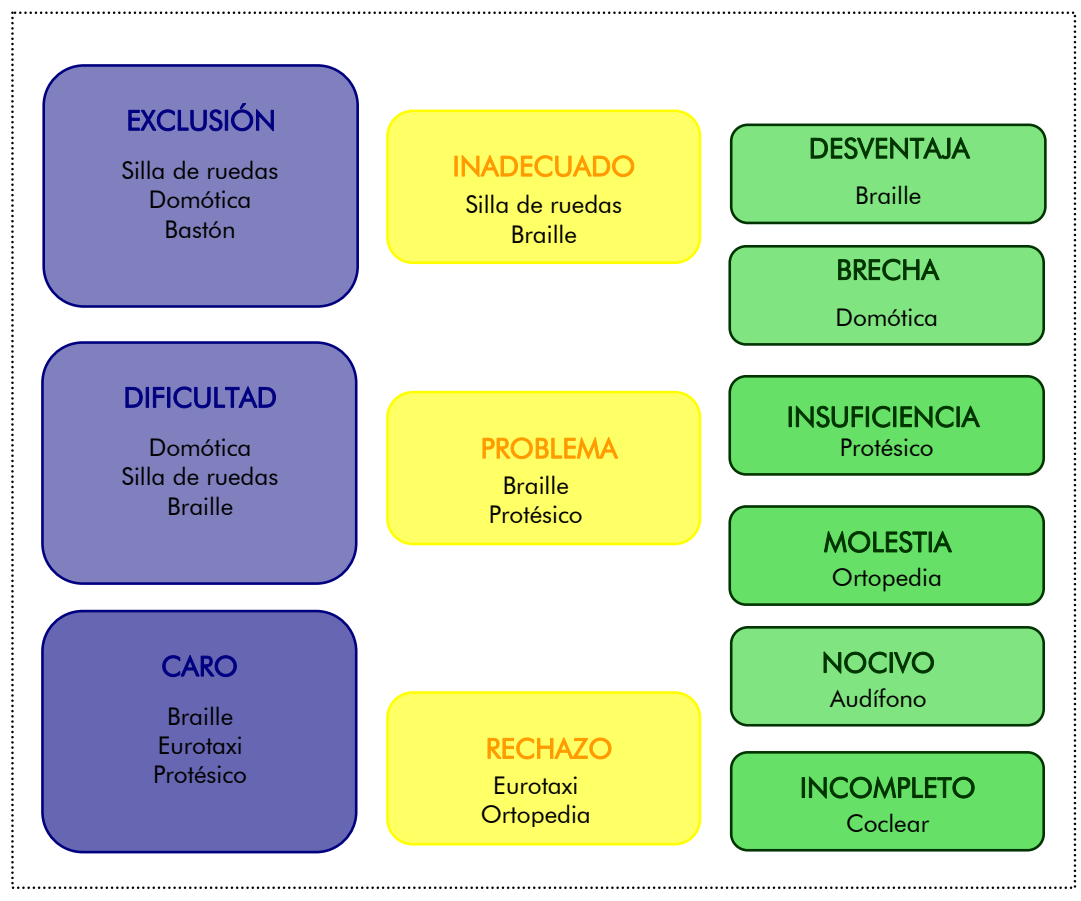

Fig. 6.17 Resumen de Grupo Tecnologías Específicas en relación a imágenes y valores negativos 


\section{C) Deseados}

En relación a las imágenes y valores que mediante los textos analizados se manifiestan como deseados para las tecnologías específicas, se advierte no sólo una disminución de la cantidad de referencias - se identificó un total de 15 -, sino además, una menor cantidad de aparatos y técnicas aludidas. (Fig. 6.18)

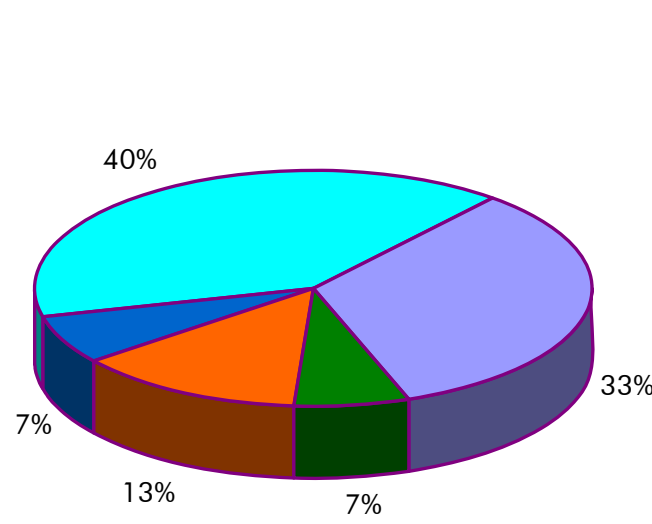
DDomótica
$\square$ Audífono
$\square$ Bastón
$\square$ Braille
$\square$ Coclear
$\square$ Eurotaxi
$\square$ Muleta
$\square$ Ortésica
Ortopedia
$\square$ Ortoprotésico
$\square$ Protésico
$\square$ Silla de ruedas
- Teleasistencia
- Tiflotécnica

Fig. 6.18 Grupo Tecnologías Específicas en relación a imágenes y valores deseados

De la silla de ruedas se espera más "accesibilidad", "adecuación", "sencillez" y que brinde más "facilidades" e "independencia". Por otro lado, a la domótica se le pide lo mismo, excepto la "adecuación", en lugar de la cual se exige una mayor "eficiencia".

En cuanto al braille se piensa que debe ser más "barato" y tener más "compatibilidad"; este último requisito es lo único que se solicita del 
Parte II. Aplicación de un modelo de cultura científico-tecnológica en las personas con discapacidad

audífono. Finalmente, de la muleta se desea que otorgue una mayor "independencia".

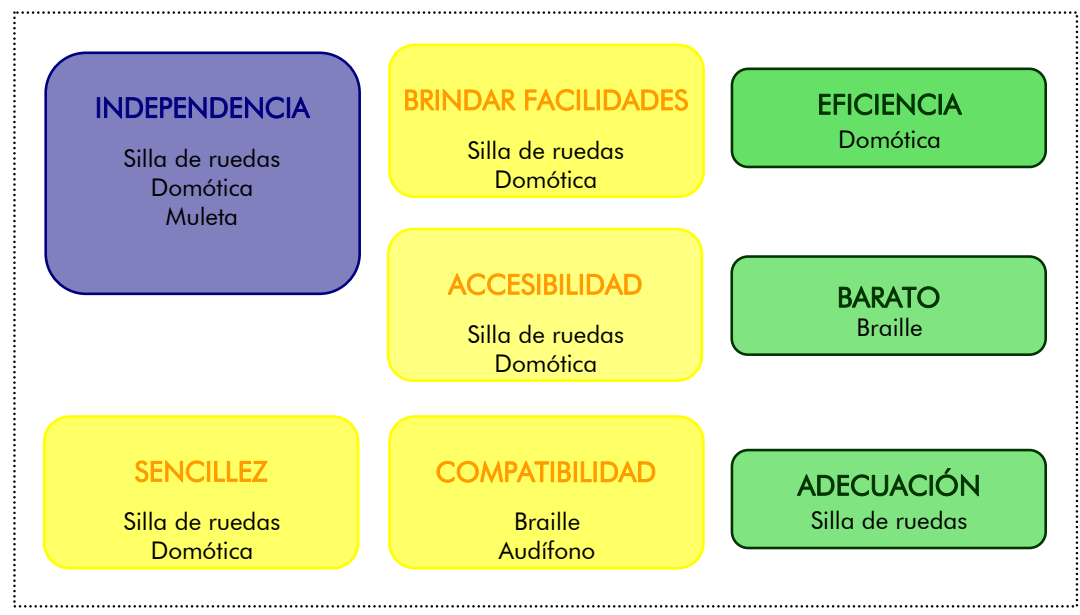

Fig. 6.19 Resumen de Grupo Tecnologías Específicas en relación a imágenes y valores deseados 
Capítulo 7. Análisis de textos periodísticos. El País y El Mundo 2002-2005. 


\subsection{El País y El Mundo. Noticias de ciencia y tecnología}

La importancia de los medios de comunicación en la sociedad actual es evidente. Experimentamos, gracias a ellos, cada día la llegada de información de manera casi instantánea de todas partes del mundo, por lo que aprehendemos diversas realidades y conformamos nuestra propia idea de realidad. La información de los medios impone debates dentro de la sociedad, ayuda a establecer prioridades legislativas o, simplemente, determina las charlas del café y la sobremesa. Qué vemos, oímos o leemos en los medios de comunicación colabora en el dinámico proceso donde se refuerzan o debilitan, según sea el caso, nuestras opiniones, prácticas o valores.

La ciencia y la tecnología están omnipresentes en la sociedad actual, influyen en la política internacional y en la relación entre un padre y su hijo, en la microeconomía de un pueblo y en la balanza comercial de un país, en el periódico escolar y en las grandes cadenas de televisión. En definitiva, son una parte fundamental de la realidad actual y el interés de la población por conocer más de ciencia y tecnología es creciente ${ }^{21}$. A través de los medios de comunicación, como canales de educación informal, es posible transmitir este conocimiento, reforzar conceptos y exponer los fraudes científicos (Shamos 1995).

A partir del inicio de la producción sistemática de saber científico en el siglo XVII, la difusión de este conocimiento ha evolucionado desde la oralidad de las demostraciones públicas (s. XVIII y s. XIX), pasando por la divulgación escrita y la enseñanza formal (s. XIX y s. XX), hasta llegar la transmisión a través de los medios de comunicación en el siglo XX, donde

\footnotetext{
${ }^{21}$ Según la FECYT en el año 2004 el interés de los ciudadanos respecto a la ciencia y la tecnología supera al manifestado sobre temas como trabajo o vida de famosos y que su grado de interés supera la oferta de información (FECYT 2005).
} 
Parte II. Aplicación de un modelo de cultura científico-tecnológica en las personas con discapacidad

se ha desarrollado y valorado cada vez más el papel que juegan los profesionales de la comunicación en la divulgación de la ciencia (Godin \& Gringas 2000).

Según la Tercera Encuesta Nacional sobre Percepción Social de la Ciencia y la Tecnología de la Fundación Española para la Ciencia y la Tecnología (FECYT 2007), la prensa diaria es el segundo medio, después de la televisión, del cual las personas obtienen información sobre temas de ciencia y tecnología.

\begin{tabular}{ll} 
Medio & \\
\hline TV & $59,9 \%$ \\
Prensa diaria de pago & $33,8 \%$ \\
Radio & $25,7 \%$ \\
Internet & $25,1 \%$ \\
Ninguno & $20,3 \%$ \\
Prensa gratuita & $16,8 \%$ \\
Revistas de divulgación científica o técnicas & $12,4 \%$ \\
Libros & $11,5 \%$ \\
Revistas de información semanal & $7,2 \%$ \\
Otras & $0,1 \%$ \\
\hline
\end{tabular}

Tabla 7.1 Fuentes de información científico-tecnológica de los ciudadanos (máximo tres respuestas)

Fuente: Percepción Social de la Ciencia y la Tecnología en España. FECYT, 2007

Dentro de la prensa diaria española, los periódicos de contenido general con mayor difusión son El País y El Mundo ${ }^{22}$. El diario El País se publica en España desde el 4 de mayo de 1976. Actualmente, en su edición impresa nacional cuenta con las siguientes secciones:

${ }^{22}$ Según la OJD (Oficina de Justificación de la Difusión) en el período de control enerodiciembre de 2006, el promedio de difusión general de ejemplares es el siguiente: El País (432.204), El Mundo (330.634), ABC (240.225), La Vanguardia (202.161), El Periódico de Catalunya (167.804), La Razón (142.838), El Correo (119.601) y La Voz de Galicia (103.112). 
- Internacional

- Opinión

- España

- Sociedad

- Gente

- Deportes

- Economía

- Radio y TV.

- $\quad$ Última

Por otra parte, la primera edición de El Mundo salió a la venta el 23 de octubre de 1989 y las secciones de su versión impresa nacional son:

- Opinión

- España

- Mundo

- Ciencia

- Economía

- Motor

- Deportes

- $\quad$ Última

Destaca la presencia, desde septiembre de 2002, de la sección Ciencia en el diario El Mundo, que naturalmente concentra la mayor cantidad de textos de ciencia y tecnología en relación a las otras secciones del mismo periódico. Por su parte, el diario El País concentra en Sociedad la mayoría de las noticias científicas, pero en ambos periódicos es posible encontrar en cualquiera de sus secciones textos con contenidos de ciencia y tecnología. 
Parte II. Aplicación de un modelo de cultura científico-tecnológica en las personas con discapacidad

\subsection{Objetivos del análisis}

Para analizar la imagen que se transmite a la sociedad de las personas con discapacidad y su relación con la ciencia y la tecnología, desde estos medios de comunicación, hemos analizado cuantitativa y cualitativamente los textos periodísticos con contenidos científicos y tecnológicos de ambos diarios.

Los objetivos del presente análisis son:

d) Identificar la información representacional, práctica y valorativa incorporada y no incorporada en las noticias de ciencia y tecnología relacionadas con la discapacidad.

e) Identificar los elementos de la ciencia y la tecnología que se relacionen con las personas con discapacidad; y analizar la relación que se establece.

f) Identificar las imágenes de la ciencia y la tecnología en relación con la discapacidad presentes en las noticias 


\subsection{Metodología}

Los textos analizados constituyen una muestra significativa de los publicados en los periódicos El País y El Mundo entre los años 2002 y 2005, ambos incluidos. La selección de la muestra se realizó mediante la técnica de semana construida, con la que se obtiene un $23 \%$ del universo. La técnica consiste en construir de manera aleatoria una semana para cada mes del año con diferentes días de diferentes semanas cada día. De este modo de los 363 días en los que se publica el diario en un año ${ }^{23}$, se consigue una muestra de 84 días por periódico.

Una vez determinadas las fechas se revisaron manualmente los 672 diarios $^{24}$ para recoger en una base de datos ACCESS todos aquellos textos que reflejaran aspectos intrínsecos de ciencia y tecnología (teorías, descubrimientos, hechos científicos, invenciones, desarrollo o difusión de una o varias tecnologías o sistemas tecnológicos), al igual que aquellas noticias que contuvieran una perspectiva extrínseca en cuanto a conocimientos, acciones y/o valores relacionados siempre con la ciencia y la tecnología.

Es así como se generó una base de 4.136 noticias de las que se codificaron las siguientes variables:

a) ID: número de identificación de la noticia en la base de datos.

b) Periódico: nombre del diario (El País o El Mundo)

c) Fecha: en formato día/mes/año

d) Título: titular del texto periodístico

e) Entrada: texto que se ubica entre el titular y el cuerpo de texto principal de la noticia. Puede estar diferenciada tipográficamente

\footnotetext{
${ }^{23}$ Los días 1 de enero y 25 de diciembre no se publican periódicos en España.

${ }^{24}$ Cifra que corresponde a cuatro años de 84 días cada uno, por los dos periódicos.
} 
Parte II. Aplicación de un modelo de cultura científico-tecnológica en las personas con discapacidad

o no del resto del texto, dependiendo de la noticia o del periódico.

f) Texto: cuerpo informativo principal del texto periodístico. ${ }^{25}$

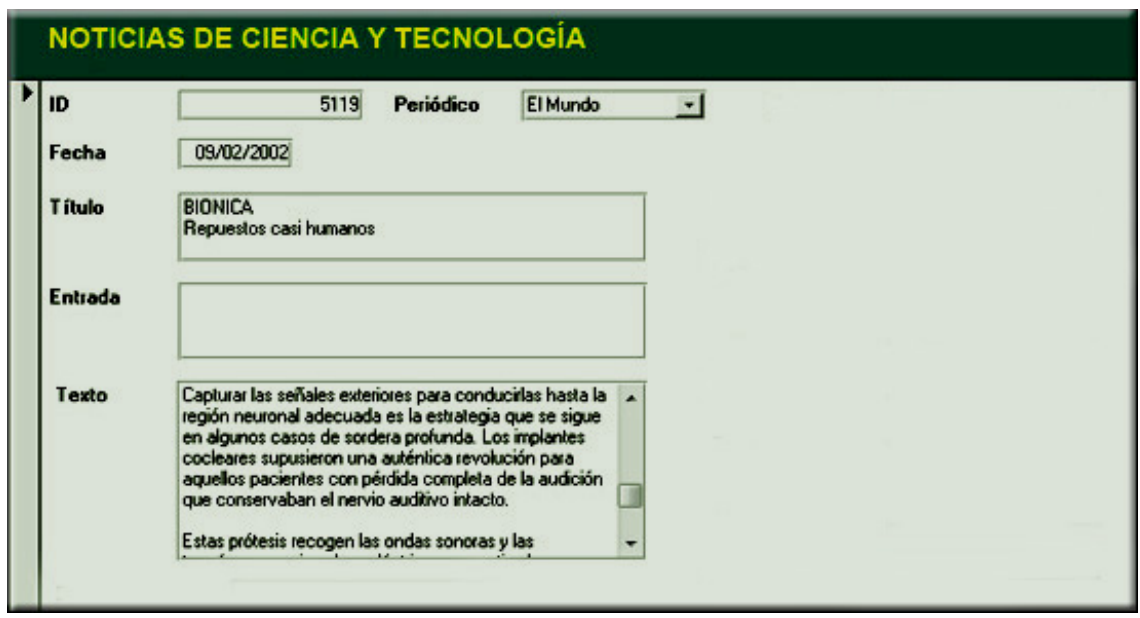

Fig. 7.1 Base de Datos Access.

${ }^{25}$ Somos conscientes de que cada texto tiene una estructura diferente, no es lo mismo una noticia que una entrevista o un reportaje que una carta al director en su composición; pero al no ser éste un análisis de tipos de textos o géneros periodísticos hemos unificado y simplificado los criterios para los campos en la base de datos. 
Posteriormente, los textos fueron exportados en formato ".txt" al programa ATLAS.ti para ser analizados.

Dentro de este corpus se identificaron, mediante búsquedas automáticas, las noticias de ciencia y tecnología que mostraban alguna relación con la temática de la discapacidad o dónde estuvieran presentes las personas con discapacidad. Para poder rescatar todos los textos se buscaron, en publicaciones especializadas ${ }^{26}$, palabras claves exclusivas de discapacidad para formar los códigos.

Los comodines de búsqueda utilizados para hacer esta criba fueron los siguientes:

\section{CODES DISCAPACIDAD}

EXTERNO: = barrera* arquitectónica* $\mid$ audífono* $\mid$ implante* coclear*| órtesis | ortoprotésic* $\mid$ pr[oó]+[eé] si* $\mid$ silla de ruedas $\mid$ DEFICIENCIA: = deficiencia* auditiva* $\mid$ deficiencia* física* $\mid$ deficiencia* intelectual ${ }^{*} \mid$ deficiencia* mental $^{*} \mid$ deficiencia* motórica* $^{*}$ deficiencia

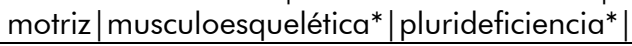

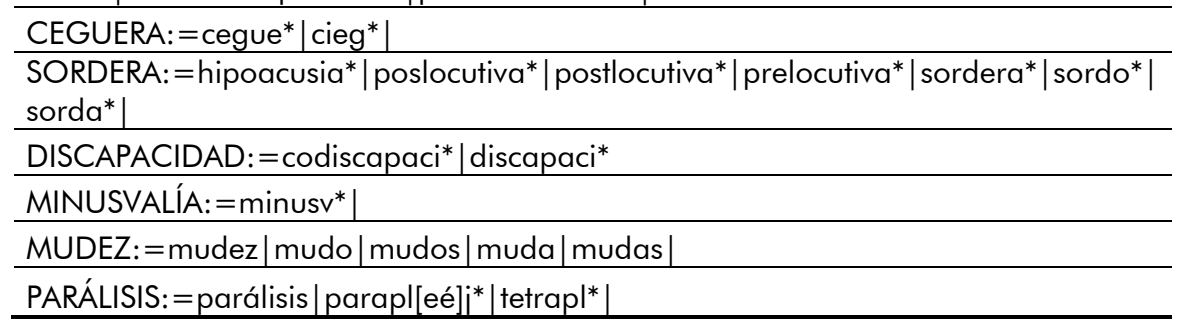

Al aplicar esta codificación automática fueron seleccionadas 135 noticias. Se procedió, entonces, a la revisión manual para eliminar falsos amigos ("hacer oídos sordos", "testigos mudos de una tragedia") y quitar contenido espurio. Al finalizar esta exploración fueron eliminados 34 textos que no hacían referencia a la temática de la discapacidad.

${ }^{26}$ Los textos utilizados fueron el Glosario del CEAPAT [http://www.ceapat.org/glosario.do\#d] y el Glosario de la Encuesta sobre Discapacidades, Deficiencias y Estado de Salud (INE 1999). 
Parte II. Aplicación de un modelo de cultura científico-tecnológica en las personas con discapacidad

Las 101 noticias restantes fueron sometidas a un completo análisis manual compuesto por cuatro partes.

En la primera etapa se identificó el peso de la presencia de la discapacidad o de las personas con discapacidad dentro del texto periodístico, según las siguientes categorías:

\begin{tabular}{ll}
\hline Peso & \\
\hline a) Toda & $\begin{array}{l}\text { Todo el texto periodístico tiene relación } \\
\text { con la discapacidad, en general o con } \\
\text { alguna específica en particular; o hay } \\
\text { presencia de PcD desde el principio al final } \\
\text { de la noticia. }\end{array}$ \\
\hline b) Parte & $\begin{array}{l}\text { Más de dos párrafos y menos de todo el } \\
\text { texto hace referencia a la discapacidad o a } \\
\text { las PcD. }\end{array}$ \\
\hline c) Párrafo & $\begin{array}{l}\text { La referencia a la discapacidad o a las } \\
\text { PcD está limitada a un párrafo o a una } \\
\text { frase dentro de un párrafo. }\end{array}$ \\
\hline
\end{tabular}

Luego se analizaron los textos vinculados con la discapacidad y las PcD según el tipo de información que transmitían aplicándoles las mismas categorías de cultura científico- tecnológica utilizadas en el análisis de la revista Minusval:

\begin{tabular}{llll}
\hline Cultura Científica & Representacional & Intrínseca & 01CRI \\
\cline { 3 - 4 } & & Extrínseca & 02CRE \\
\cline { 2 - 4 } & Práctica & Intrínseca & $03 \mathrm{CPI}$ \\
\cline { 3 - 4 } & & Extrínseca & $04 \mathrm{CPE}$ \\
\cline { 2 - 4 } & Valorativa & Intrínseca & $05 \mathrm{CVI}$ \\
\cline { 3 - 4 } Cultura Tecnológica & Representacional & Intrínseca & $07 \mathrm{TRI}$ \\
\cline { 2 - 4 } & & Extrínseca & $08 \mathrm{TRE}$ \\
\cline { 2 - 4 } & Práctica & Intrínseca & $09 \mathrm{TPI}$ \\
\cline { 2 - 4 } & & Extrínseca & $10 \mathrm{TPE}$ \\
\cline { 2 - 4 } & & Intrínseca & $11 \mathrm{TVI}$ \\
\cline { 2 - 4 } & Valorativa & Extrínseca & $12 \mathrm{TVE}$ \\
\hline
\end{tabular}


La tercera parte del análisis consistió en identificar la relación de las personas con discapacidad y las tecnologías. Las categorías utilizadas fueron:

\begin{tabular}{ll}
\hline Relación & \\
\hline Receptor. & $\begin{array}{l}\text { Destinatario de tecnologías desarrolladas por } \\
\text { científicos y tecnólogos. }\end{array}$ \\
\hline Usuario. & $\begin{array}{l}\text { Consumidor y usuario de tecnologías específicas } \\
\text { para PcD, generales o generales adaptadas. }\end{array}$ \\
\hline Generador. & Agente activo en el sistema científico-técnico. \\
\hline SR & Sin relación con la tecnología \\
\hline
\end{tabular}

Finalmente, la cuarta etapa del análisis consistió en detallar cuáles eran las imágenes y valores asociados a las tecnologías con relación a las PcD. Se examinaron los textos aplicando las categorías identificadas en el estudio de la revista Minusval. Se siguió con el esquema utilizado ${ }^{27}$, finalmente se desechó la categoría de valores "deseados" por su prácticamente nula presencia en los textos.

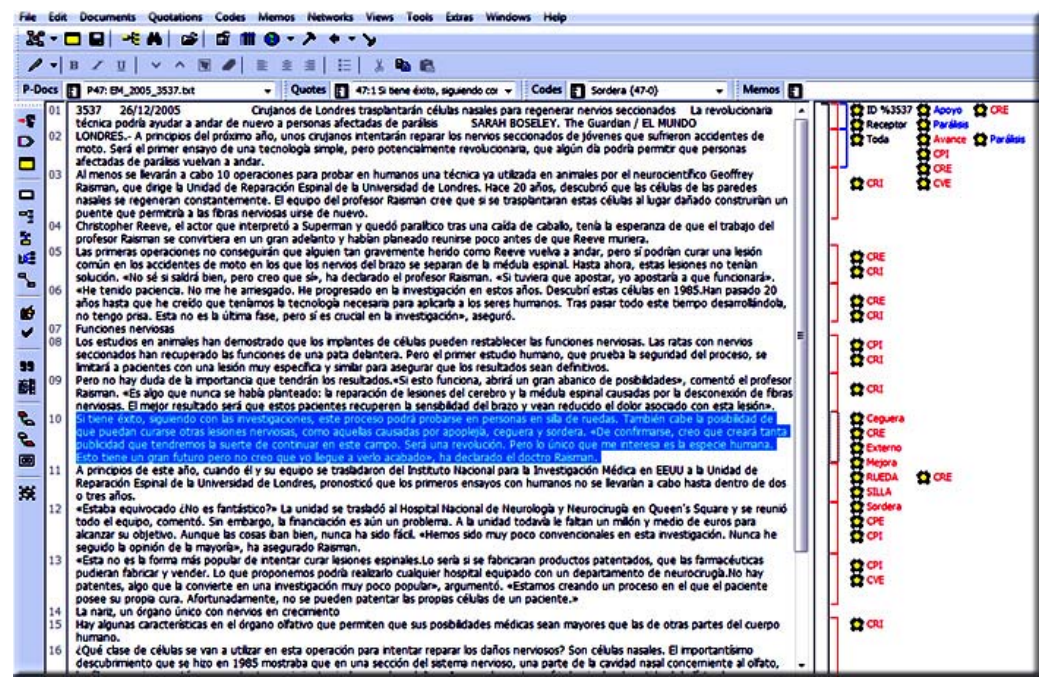

Fig. 7.2 Ejemplo del análisis de las noticias con el programa informático de análisis de contenido ATLAS.ti

${ }^{27}$ Cfr. pp. 119 - 120, Capítulo 5. 
Parte II. Aplicación de un modelo de cultura científico-tecnológica en las personas con discapacidad

\subsection{Resultados}

\subsubsection{Generales}

7.4.1.1 El Peso de la cultura científico-tecnológica en la prensa

Para conocer mejor la relevancia que tiene la cultura científico-tecnológica en un contexto general, podemos comparar el volumen de noticias científicas con el total de textos periodísticos publicados por El País y El Mundo durante el periodo estudiado. De este modo, es posible obtener un porcentaje del peso que tienen estas noticias dentro de los periódicos.

\section{El País El Mundo}

Total

№ de textos de noticias científico-

tecnológicas (muestra)

\subsection{8}

1.898

Total de noticias científico -

tecnológicas (estimación 2002-2005)

8.252

17.983

Total noticias (estimación 2002-2005)

$\%$ cultura científica

$3,89 \%$

$3,75 \%$

$3,82 \%$

Tabla 7.2 Estimación entre los textos periodísticos de cultura científica y el total de textos publicados entre 2002 y 2005.

Fuente: Montero 2007:39

Recordemos que la selección de la muestra se realizó mediante la técnica de semana construida, con la que se obtiene un $23 \%$ del universo. Así pues, se estima que el total de noticias científico-tecnológicas publicadas entre el año 2002 y el 2005 por los dos periódicos llegaría a 17.983 (Montero 2007).

Por otro lado, observamos en la Tabla 7.2 que la estimación del total de textos informativos asciende, entre El País y El Mundo, a 470.000 en el periodo mencionado y en consecuencia el peso de la cultura científico- 
tecnológica, dentro del total de noticias publicadas por los dos periódicos, corresponde a un $3,82 \%$.

7.4.1.2 El Peso de la discapacidad dentro de la cultura científico-tecnológica en la prensa

En vista de los datos obtenidos, podemos calcular también cuál es la representación que tienen los temas relacionados con la discapacidad dentro de la información científico-tecnológica publicada en la prensa.

El País El Mundo Total

№ Total de noticias de discapacidad en la muestra 50 51 101

Total de noticias de discapacidad (estimación 2002-2005)

Total de noticias científico - tecnológicas (estimación 2002-2005)

$\%$ discapacidad dentro de la cultura científica

Tabla 7.3 Estimación entre los textos periodísticos de discapacidad y el total de textos de cultura científica publicados entre 2002 y 2005.

Vemos que el número de textos de ciencia y tecnología asociadas a la discapacidad, dentro de la muestra que corresponde al 23\% del total publicado, es de 101 noticias. En consecuencia, el total aproximado de textos científico-tecnológicos relacionados con esta temática entre 2002 y 2005 llega a 439, cifra que corresponde al 2,46\%. Esto es, el peso de la discapacidad en la información de ciencia y tecnología en El País y El Mundo es menor que el de la cultura científico-tecnológica en todo el periódico. 
Parte II. Aplicación de un modelo de cultura científico-tecnológica en las personas con discapacidad

Si observamos la evolución temporal por periódico de la cantidad de noticias de ciencia y tecnología en las que se identifica la presencia de la temática de la discapacidad (Fig. 7.3), podemos ver que su número va creciendo claramente a lo largo de los cuatro años en el diario El Mundo. No así en El País que mantiene aproximadamente la misma cantidad de textos en 2002 y 2003, para luego igualarse con El Mundo en 2004 y superarlo en 2005.

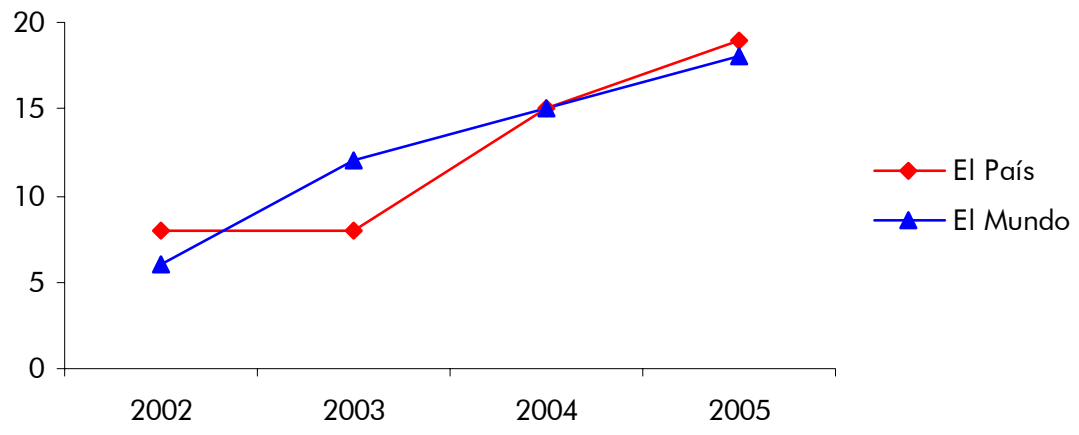

Fig. 7.3 Evolución temporal por periódico 


\subsubsection{Presencia de la discapacidad en las noticias de ciencia y tecnología}

Dentro de las 101 noticias de ciencia y tecnología que tuvieran relación con la discapacidad, se advierte el alto porcentaje de textos (44\%) en los cuales el tema central está vinculado con la discapacidad, en general, o con alguna específica en particular. (Fig. 7.4)

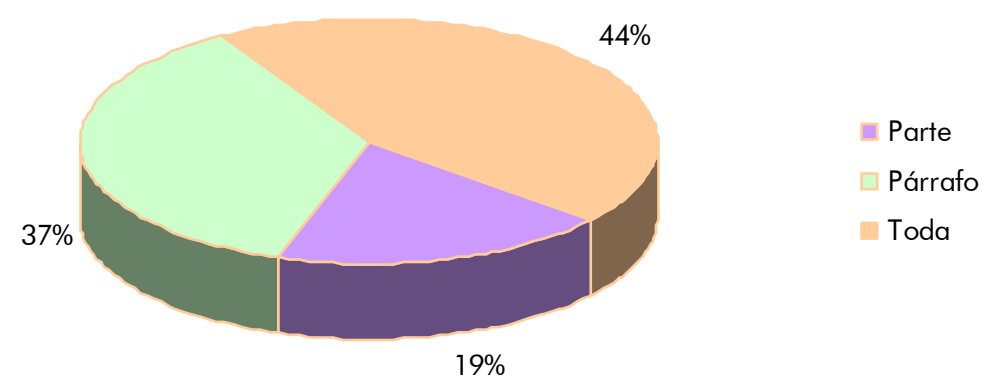

Fig. 7.4 Presencia de la discapacidad en las noticias de ciencia y tecnología

Por otro lado, se observa que un 19\% de las noticias analizadas presenta esta temática en más de dos párrafos y menos de todo el texto. Finalmente, en un $37 \%$ de los casos la referencia a la discapacidad o a las PcD está limitada a un párrafo o a una frase dentro de un párrafo.

Vemos, por lo tanto, que a pesar de la escasa representación de la discapacidad en las noticias de ciencia y tecnología, cuando aparece lo hace con un papel protagonista dentro de los textos; como lo demuestra el porcentaje acumulado de aquéllos en los que las PcD tienen una figuración total o parcial (63\%), en comparación con las noticias dónde sólo aparecen en un párrafo o en una frase. 
Parte II. Aplicación de un modelo de cultura científico-tecnológica en las personas con discapacidad

\subsubsection{Cultura científico-tecnológica y PcD}

A diferencia de lo que hemos visto en el análisis de la revista Minusval, en la prensa se distingue un claro predominio de temas científicos, por sobre los tecnológicos (Fig. 7.5). Dentro de las 101 noticias estudiadas, hemos encontrado 298 referencias a cultura científico-tecnológica, de las cuales el $60 \%$ corresponde a información científica y $40 \%$ restante a conocimiento tecnológico.

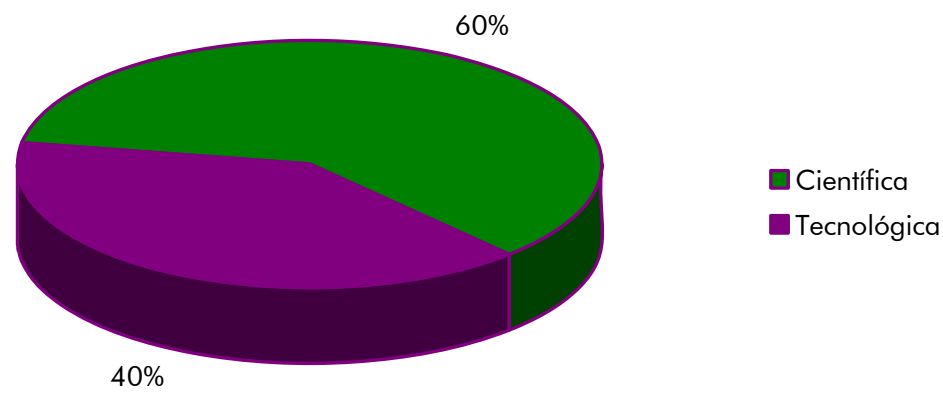

Fig. 7.5 Cultura científico-tecnológica en las noticias

Dentro de la información científica que se transmite en las noticias (Tabla 7.4), observamos que la más destacada es aquella de contenidos representacionales intrínsecos a la ciencia, con un $35,6 \%$ de las 180 referencias identificadas.

\begin{tabular}{ccccccc}
\hline \multicolumn{7}{c}{ Cultura Científica } \\
\hline Total & $\begin{array}{c}\text { Práctica } \\
\text { Extrínseca }\end{array}$ & $\begin{array}{c}\text { Práctica } \\
\text { Intrínseca }\end{array}$ & $\begin{array}{c}\text { Repr. } \\
\text { Extrínseca }\end{array}$ & $\begin{array}{c}\text { Repr. } \\
\text { Intrínseca }\end{array}$ & $\begin{array}{c}\text { Valorativa } \\
\text { Extrínseca }\end{array}$ & $\begin{array}{c}\text { Valorativa } \\
\text { Intrínseca }\end{array}$ \\
\hline 180 & $18,3 \%$ & $15,6 \%$ & $22,2 \%$ & $35,6 \%$ & $7,8 \%$ & $0,6 \%$ \\
\hline
\end{tabular}

Tabla 7.4 Cultura científica en la prensa 
En el siguiente párrafo vemos como son presentados en las noticias los conocimientos intrínsecos de la ciencia; se transmite información sobre el ictus, utilizando términos propios de la terminología científica.

Un ictus o accidente cerebrovascular puede producirse por un coágulo que obstruye el vaso sanguíneo (ictus isquémico) o por una rotura de dicho vaso (ictus hemorrágico). El resultado final es el mismo: una zona del cerebro queda privada de riego sanguíneo. Si la privación es severa y prolongada se produce, como consecuencia del ictus, un infarto cerebral, es decir, la muerte de las células que han dejado de recibir aporte sanguíneo. Como consecuencia de todo ello se puede producir la muerte del paciente o alguna discapacidad.

El País $\quad 04 / 03 / 2003$

Descubren un agente natural que pronostica el daño cerebral tras un ictus

Además de las representaciones intrínsecas, se identifican imágenes extrínsecas, que corresponden al 22,2\% del total de información relativa a la ciencia en las noticias. Tenemos un ejemplo de ello en las siguientes líneas, donde podemos observar una visión de la ciencia utilitarista y como un factor de cambio de la realidad.

Quienes están a favor ven enormes beneficios en la clonación. Como salvar especies en vías de extinción, fortalecer las razas, crear gatos que no produzcan alergia, mascotas diseñadas especialmente para ayudar a los impedidos, a los ciegos o a la policía; amén del consuelo que puede representar para los amos que pierden a sus acompañantes.

El País

25/03/2002

¿Me pone un gato igual que éste?

Los contenidos con menos alusiones son los valores científicos intrínsecos, con sólo un $0,6 \%$. 
Parte II. Aplicación de un modelo de cultura científico-tecnológica en las personas con discapacidad

Al analizar los datos según el periódico (Tabla 7.5), se advierte un mayor número de referencias a contenidos científicos relacionados con la discapacidad en El Mundo, entre los que sobresale la información sobre imágenes desde una perspectiva intrínseca a la ciencia (representacional intrínseca). Los contenidos científicos extrínsecos también están presentes en un lugar relevante, con un $22,5 \%$.

\begin{tabular}{llcc}
\hline & & \multicolumn{2}{c}{ Periódico } \\
\cline { 3 - 4 } Cultura & Total & 111 & 69 \\
Científica & Pl Mundo & El País \\
\cline { 2 - 3 } & Práctica Extrínseca & $19,8 \%$ & $15,9 \%$ \\
& Representacínseca & $17,1 \%$ & $13,0 \%$ \\
& Representacional Extrínseca & $22,5 \%$ & $21,7 \%$ \\
& Valorativa Extrínseca & $30,6 \%$ & $43,5 \%$ \\
& Valorativa Intrínseca & $9,0 \%$ & $5,8 \%$ \\
& & $0,9 \%$ & $0,0 \%$ \\
\hline
\end{tabular}

Tabla 7.5 Cultura científica por periódico

En cuanto al diario El País, vemos que al igual que en El Mundo, pero proporcionalmente en mayor medida, los contenidos más transmitidos son los representacionales intrínsecos, lo que nos habla de una destacada labor de transmisión de conocimientos científicos en las noticias de ciencia y tecnología relacionadas con la discapacidad. La visión externa de la ciencia se observa en el periódico El País en un porcentaje similar al del diario El Mundo.

Llama la atención la falta de valores científicos intrínsecos en El País, que si bien sabemos no son de habitual presencia en textos periodísticos, sí aparecen en un pequeño porcentaje en El Mundo.

En lo que concierne a la información tecnológica en las noticias (Tabla 7.6), se observa, al igual que sucedía con la cultura científica, una mayor 
presencia de contenidos representacionales extrínsecos, con un $43,2 \%$ de las 118 de las citas.

\begin{tabular}{ccccccc}
\hline \multicolumn{8}{c}{ Cultura Tecnológica } \\
\hline Total & $\begin{array}{c}\text { Práctica } \\
\text { Extrínseca }\end{array}$ & $\begin{array}{c}\text { Práctica } \\
\text { Intrínseca }\end{array}$ & $\begin{array}{c}\text { Repr. } \\
\text { Extrínseca }\end{array}$ & $\begin{array}{c}\text { Repr. } \\
\text { Intrínseca }\end{array}$ & $\begin{array}{c}\text { Valorativa } \\
\text { Extrínseca }\end{array}$ & $\begin{array}{c}\text { Valorativa } \\
\text { Intrínseca }\end{array}$ \\
\hline 118 & $17,8 \%$ & $7,6 \%$ & $43,2 \%$ & $19,5 \%$ & $10,2 \%$ & $1,7 \%$ \\
\hline
\end{tabular}

Tabla 7.6 Cultura tecnológica en la prensa

La información externa a los sistemas tecnológicos es aquella que, como vemos en el siguiente ejemplo, se refiere a la tecnología - la "máquina", en este caso -, pero desde un punto de vista extrínseco. La visión de la máquina por parte de las personas mayores o discapacitadas como un "ser" amigable o impersonal, afecta a su uso, sin embargo esta representación no constituye información interna del sistema técnico.

Cuando se trata de prestar ayuda en un entorno doméstico, la apariencia amigable de una máquina facilita mucho la interacción y su aceptación. A una persona mayor o con discapacidades físicas le resulta más fácil dar órdenes a alguien que le recuerda a un asistente que no a una máquina impersonalizada.

$$
\text { El País }
$$

"Nuestra meta es un robot con el que se pueda convivir"

En segundo lugar, pero en menor medida con un 19,5\%, observamos información intrínseca a las técnicas y a los sistemas técnicos, seguida de cerca por la referida a los conocimientos operacionales externos a la tecnología, con un $17,8 \%$.

Tenemos, por lo tanto, presencia de información incorporada a los sistemas, como pueden ser las medidas de un dispositivo electrónico ("retina artificial"), su forma y lugar de aplicación, estructura y funcionamiento. 
Parte II. Aplicación de un modelo de cultura científico-tecnológica en las personas con discapacidad

La 'retina artificial', nombre con el que se conoce popularmente al dispositivo, es una prótesis microelectrónica diseñada para sustituir a las células dañadas por enfermedades como la retinosis pigmentaria o la degeneración macular, dolencias que causan ceguera o graves deficiencias visuales y afectan a más de 25 millones de personas en todo el mundo. El implante mide apenas unos milímetros y se inserta quirúrgicamente en el fondo de la retina. Está integrado por 16 electrodos y funciona cuando éstos reciben la información visual que capta una diminuta cámara instalada en unas gafas especiales.

\section{El Mundo}

$07 / 05 / 2005$

Una «retina artificial» devuelve parte de la visión a seis ciegos

Si distinguimos por periódico (Tabla 7.7), notamos una leve diferencia entre El Mundo y El País, al tener este último mayor número de contenidos tecnológicos, entre los que, al contrario que en la información científica, sobresale la referida a las representaciones externas a la tecnología, con un $46 \%$ del total.

\begin{tabular}{llcc}
\hline & & \multicolumn{2}{c}{ Periódico } \\
\cline { 3 - 4 } & & El Mundo & El País \\
\hline Cultura & Total & 55 & 63 \\
& Práctica Extrínseca & $16,4 \%$ & $19,0 \%$ \\
& Práctica Intrínseca & $9,1 \%$ & $6,3 \%$ \\
& Representacional Extrínseca & $40,0 \%$ & $46,0 \%$ \\
& Representacional Intrínseca & $21,8 \%$ & $17,5 \%$ \\
& Valorativa Extrínseca & $10,9 \%$ & $9,5 \%$ \\
& Valorativa Intrínseca & $1,8 \%$ & $1,6 \%$
\end{tabular}

Tabla 7.7 Cultura tecnológica por periódico 
El periódico El Mundo, por su parte, dentro de los diferentes tipos de conocimiento tecnológico que ofrece en sus noticias entrega mayor número de información representacional extrínseca, pero en menor porcentaje y frecuencia que El País.

Pasemos a continuación a analizar los datos según la información científico-tecnológica sea incorporada o no incorporada. En el primer caso, es decir, cuando los contenidos aluden a aspectos intrínsecos de la ciencia o la tecnología (Tabla 7.8), los que tienen mayor representación son los conocimientos, creencias y representaciones conceptuales 0 simbólicas de la ciencia. Le siguen las prácticas o reglas y pautas de comportamiento también científicas y, luego, las representaciones acerca de los componentes, estructura y funcionamiento interno del sistema tecnológico.

\begin{tabular}{ccccccc}
\hline \multicolumn{7}{c}{ Cultura Científico-Tecnológica Intrínseca } \\
\hline Total & Cnt. Prct. & Cnt. Rep. & Cnt. Vlr. & Tcn. Prct. & Tcn. Rep. & Tcnl. Vlr. \\
\hline 127 & $22,0 \%$ & $50,4 \%$ & $0,8 \%$ & $7,1 \%$ & $18,1 \%$ & $1,6 \%$ \\
\hline
\end{tabular}

Tabla 7.8 Cultura científico-tecnológica intrínseca

Examinados los datos por cada periódico, se observa que el diario El Mundo ofrece a sus lectores mayor cantidad de información intrínseca que El País, pero que proporcionalmente ambos entregan el mismo volumen de cada tipo de contenidos, a excepción de los valores científicos que se advierten sólo en El Mundo. 
Parte II. Aplicación de un modelo de cultura científico-tecnológica en las personas con discapacidad

\begin{tabular}{llcc}
\hline & & \multicolumn{2}{c}{ Periódico } \\
\cline { 3 - 4 } & & El Mundo & El País \\
\hline Cultura & Total & 72 & 55 \\
$\begin{array}{l}\text { Científico } \\
\text { Tecnológica }\end{array}$ & Cnt. Prct. & $26,4 \%$ & $16,4 \%$ \\
Intrínseca & Cnt. Rep. & $47,2 \%$ & $54,5 \%$ \\
& Cnt. Vlr. & $1,4 \%$ & $0,0 \%$ \\
& Tcn. Prct. & $6,9 \%$ & $7,3 \%$ \\
& Tcn. Rep. & $16,7 \%$ & $20,0 \%$ \\
& Tcnl. Vlr. & $1,4 \%$ & $1,8 \%$ \\
\hline
\end{tabular}

Tabla 7.9 Cultura científico-tecnológica intrínseca por periódico

Revisemos ahora la distribución de la cultura científico-tecnológica extrínseca (Tabla 7.10). Según este criterio, el tipo de conocimiento más difundido es el relacionado con representaciones que no forman parte de los sistemas técnicos, pero que son relevantes para su diseño, producción y uso. El segundo lugar le corresponde a las representaciones de la ciencia.

\begin{tabular}{ccccccc}
\hline \multicolumn{7}{c}{ Cultura Científico-Tecnológica Extrínseca } \\
\hline Total & Cnt. Prct. & Cnt. Rep. & Cnt. Vlr. & Tcn. Prct. & Tcn. Rep. & Tcnl. Vlr. \\
\hline 171 & $19,3 \%$ & $23,4 \%$ & $8,2 \%$ & $12,3 \%$ & $29,8 \%$ & $7,0 \%$ \\
\hline
\end{tabular}

Tabla 7.10 Cultura científico-tecnológica extrínseca

Separados los resultados según el periódico, vemos nuevamente un mayor número de referencias en el diario El Mundo, que entrega más conocimiento representacional científico (26\%) y la misma cantidad de información de prácticas científicas que de representaciones de la tecnología (ambas con un 23,4\%). 
Por su parte, el diario El País transmite más creencias extrínsecas sobre las técnicas y sobre los sistemas técnicos que El Mundo, con un $37,7 \%$; y menos información representacional externa de la ciencia, con un 19,5\%.

\begin{tabular}{llcc}
\hline & & \multicolumn{2}{c}{ Periódico } \\
\cline { 3 - 4 } & & El Mundo & El País \\
\hline Cultura & Total & 94 & 77 \\
Científico & Cnt. Prct. & $23,4 \%$ & $14,3 \%$ \\
Eecnológica & Cnt. Rep. & $26,6 \%$ & $19,5 \%$ \\
& Cnt. Vlr. & $10,6 \%$ & $5,2 \%$ \\
& Tcn. Prct. & $9,6 \%$ & $15,6 \%$ \\
& Tcn. Rep. & $23,4 \%$ & $37,7 \%$ \\
& Tcnl. Vlr. & $6,4 \%$ & $7,8 \%$ \\
\hline
\end{tabular}

Tabla 7.11 Cultura científico-tecnológica extrínseca por periódico

\subsubsection{Relación de las PcD con la tecnología}

Para poder caracterizar de manera más completa la relación entre las personas con discapacidad y las tecnologías, como hemos señalado en la metodología, examinaremos el rol de los discapacitados que se proyecta en los textos periodísticos pudiendo así identificar, en primer lugar, si existe o no relación, y en caso de existir, cómo es.

Al examinar las noticias hemos encontrado que hay 114 ocasiones en las que aparecen personas con discapacidad en ellas, de las cuales, en el $27 \%$ no muestran relación con la tecnología, como vemos en la Fig. 7.6. 
Parte II. Aplicación de un modelo de cultura científico-tecnológica en las personas con discapacidad

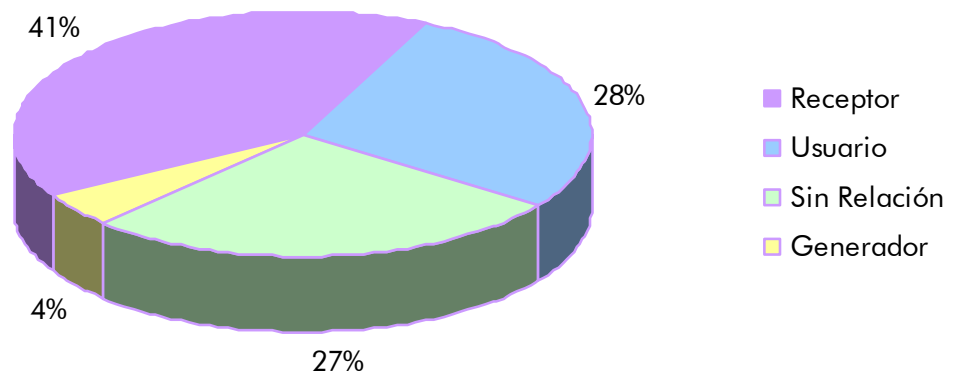

Fig. 7.6 Imagen de las PcD en las noticias en su relación con la tecnología

En el $41 \%$ de las veces las PcD son representadas como receptoras, esto es como destinatarias de tecnologías desarrolladas por científicos y tecnólogos. En el siguiente extracto de la noticia titulada "Un mono logra utilizar un ordenador con la mente" se distingue con claridad esta imagen.

El nuevo trabajo es un paso adelante para conseguir que las personas con parálisis puedan mover un cursor valiéndose del pensamiento, lo que les permitirá manejar un ordenador, con todas las ventajas que proporciona la informática: correo electrónico, Internet, y otras funciones de movimiento de miembros robóticos.

Se espera también poder aplicar esta tecnología para restaurar cierto control de movimientos en pacientes con parálisis o lesiones de la médula espinal.

«Por lo que sabemos, nadie ha sido capaz de mover un cursor de una manera tan rápida y precisa», declaró Mijail Serruya, uno de los investigadores.

Serruya añadió que el grupo de científicos ha creado una compañía para desarrollar un aparato médico que ayude a personas con parálisis.

El Mundo 14/03/2002

Un mono logra utilizar un ordenador con la mente 
Otra imagen que se proyecta de las PcD en relación a las tecnologías es la de consumidor o usuario de tecnologías específicas para discapacitados, tecnologías generales o generales adaptadas. Esta se proyecta en un $28 \%$ de los casos y muestra a las personas con discapacidad utilizando un aparato tecnológico o como posible comprador de uno.

Los usuarios ciegos podían, hasta ahora, utilizar los teléfonos móviles habituales, pero con serias dificultades. No tenían acceso a los mensajes de texto o a la agenda. Incluso las funciones más simples, como consultar el estado de la batería o la hora, eran completamente imposibles para ellos.

ONCE y Owasys han trabajado de forma conjunta en el diseño de este terminal para superar todos esos obstáculos. El 22C tiene un sintetizador de voz capaz de leer al usuario el contenido de los mensajes, informarle del estado de cobertura y la carga de la batería o señalarle quién es la persona que le está llamando.

Otros detalles, como las teclas en relieve o el altavoz de alta potencia, facilitarán el manejo a los usuarios. Se comercializará en los puntos de venta de Telefónica Móviles y en las oficinas de la ONCE y su precio será de 400 euros.

El Mundo

04/04/2004

Este móvil no utiliza el sentido de la vista

Además de haber caminado sobre nuestro satélite, este pionero de la exploración espacial ha sobrevivido a 66 combates aéreos en la guerra de Corea y ha superado enfermedades como el alcoholismo, la depresión y la sordera aguda. De hecho, su reciente paso por Europa se debe a la promoción del Savia, un audífono inteligente -capaz de discriminar los ruidos no deseados- desarrollado por la compañía Phonak y que él mismo utiliza. 
Parte II. Aplicación de un modelo de cultura científico-tecnológica en las personas con discapacidad

Se quedó sorda a los seis años, cuando sabía leer y escribir y ya había desarrollado el lenguaje. "Mi entorno era oyente y a los 27 años me pusieron el implante". Se trata de un electrodo que se coloca en el oído interno y que va acoplado por fuera a un procesador exterior. Piensa que ser sorda poslocutiva la convertía en una candidata idónea para el implante. Aunque no ha sido la panacea. "No entiendo completamente lo que oigo; tengo que interpretarlo. Sigo siendo una persona sorda", afirma. Su experiencia le dice que el implante no ofrece las mismas posibilidades a todos los sordos: "Para mí, la música es un ruido, pero para otras personas implantadas la música es un sonido muy agradable". "Aun así, sus expectativas se han cumplido. "No oigo como un oyente, pero yo ya sabía que iba a influir el tiempo que llevaba sorda", agrega.

El País

$30 / 05 / 2005$

"Quiero oír y recibir más información"

Por último, advertimos que en un pequeño porcentaje, $4 \%$, se proyecta de la imagen de PcD como un agente activo en el sistema científicotécnico (generador).

En los últimos años se ha avanzado mucho en el tratamiento de las lesiones medulares, con el desarrollo de prótesis más eficaces, la electroestimulación, los marcapasos diafragmáticos, la inseminación artificial, la prevención y el tratamiento de las escaras (llagas causadas por la inmovilidad) y la solución de problemas respiratorios, digestivos, circulatorios y urinarios.

Sin embargo, como señala Alberto de Pinto, presidente de la Federación Nacional de Asociaciones de Lesionados Medulares (ASPAYM), hace falta una clara voluntad política para mejorar la situación de las personas discapacitadas. "Hemos pasado del puedo prometer y prometo de Suárez al puedo cumplir, pero no cumplo, de ahora", señala este médico 
retirado, que quedó parapléjico cuando, en 1971, sufrió un accidente de automóvil. Se sobrepuso a la desgracia, estudió y, durante 20 años, ejerció la profesión en el hospital de Toledo, un historial que, sostiene, no debería resultar sorprendente si la sociedad estuviera concienciada. "Hay un divorcio entre las palabras y la letra impresa de las mil y una normas y su grado de desarrollo y aplicación. Después de todo, żqué es lo que pedimos? Tan sólo que nuestras limitaciones no supongan un obstáculo insalvable para gozar de las mismas oportunidades que el resto de la gente, en igualdad de justicia y de derechos. Contribuir a hacerlo posible es el gran objetivo de la nueva fundación."

El País

02/08/2004

Hay vida en una silla de ruedas

El análisis de los datos por periódico no arrojaba conclusiones significativas respecto a esta clasificación. Ambos diarios presentan a las personas con discapacidad en su relación con la tecnología en frecuencias similares. 
Parte II. Aplicación de un modelo de cultura científico-tecnológica en las personas con discapacidad

7.4.5 Valores e imágenes asociadas a las tecnologías en relación a las PcD

Continuando con la investigación, identificamos 99 referencias a las imágenes y los valores científico-tecnológicos en relación con la discapacidad presentes en las noticias.

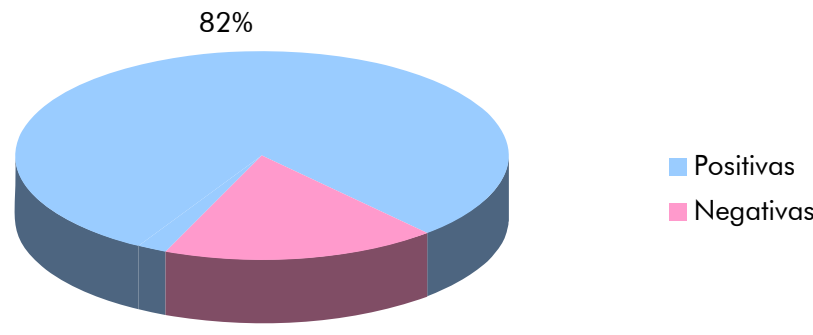

$18 \%$

Fig. 7.7 Imágenes y valores de la tecnología en su relación con las PcD en las noticias

El $82 \%$ de las imágenes corresponde a visiones positivas de la tecnología y el $18 \%$ a negativas para los aparatos tecnológicos o técnicas encontradas en los textos periodísticos.

\section{Positivos}

Dentro de las imágenes y valores que se proyectan en los periódicos, destaca la visión de la tecnología como fuente de "mejora", con un 12,7\% de las 79 referencias positivas encontradas. Asimismo, sobresale la idea de que la tecnología facilita las acciones y el desenvolvimiento en la vida diaria, con un $11,4 \%$ de las menciones (Tabla 7.12). 


\begin{tabular}{llc}
\hline Imágenes y & Total & 79 \\
& Mejora & $12,7 \%$ \\
& Facilitar & $11,4 \%$ \\
& Independencia & $8,9 \%$ \\
& Oportunidad & $7,6 \%$ \\
Apoyo & $6,3 \%$ \\
Comunicación & $6,3 \%$ \\
Solución & $6,3 \%$ \\
Accesibilidad & $3,8 \%$ \\
Avance & $3,8 \%$ \\
Calidad de Vida & $3,8 \%$ \\
Inteligencia & $3,8 \%$ \\
Beneficio & $2,5 \%$ \\
Natural & $2,5 \%$ \\
Eficiencia & $2,5 \%$ \\
Ventaja & $2,5 \%$ \\
Adecuación & $1,3 \%$ \\
Calidad & $1,3 \%$ \\
Cambio & $1,3 \%$ \\
Confianza & $1,3 \%$ \\
Efectividad & $1,3 \%$ \\
Eficacia & $1,3 \%$ \\
Fiabilidad & $1,3 \%$ \\
Innovación & $1,3 \%$ \\
Nersatilidad & $1,3 \%$ \\
Precisión & $1,3 \%$ \\
\hline & $1,3 \%$ \\
\hline & & $1,3 \%$ \\
\hline
\end{tabular}

Tabla 7.12 Imágenes y valores positivos en la prensa 
Parte II. Aplicación de un modelo de cultura científico-tecnológica en las personas con discapacidad

\begin{tabular}{|c|c|c|c|}
\hline & & \multicolumn{2}{|c|}{ Periódicos } \\
\hline & & El Mundo & El País \\
\hline \multirow{27}{*}{$\begin{array}{l}\text { Características y } \\
\text { Valores Positivos }\end{array}$} & Total & 43 & 36 \\
\hline & Accesibilidad &, $0 \%$ & $8,3 \%$ \\
\hline & Adecuación &, $0 \%$ & $2,8 \%$ \\
\hline & Apoyo & $7,0 \%$ & $5,6 \%$ \\
\hline & Avance & $4,7 \%$ & $2,8 \%$ \\
\hline & Beneficio &, $0 \%$ & $5,6 \%$ \\
\hline & Calidad &, $0 \%$ & $2,8 \%$ \\
\hline & Calidad de Vida & $2,3 \%$ & $5,6 \%$ \\
\hline & Cambio &, $0 \%$ & $2,8 \%$ \\
\hline & Comunicación & $4,7 \%$ & $8,3 \%$ \\
\hline & Confianza & $2,3 \%$ &, $0 \%$ \\
\hline & Efectividad &, $0 \%$ & $5,6 \%$ \\
\hline & Eficiencia & $2,3 \%$ & $2,8 \%$ \\
\hline & Facilitar & $9,3 \%$ & $13,9 \%$ \\
\hline & Fiabilidad &, $0 \%$ & $2,8 \%$ \\
\hline & Independencia & $14,0 \%$ & $2,8 \%$ \\
\hline & Innovación & $2,3 \%$ &, $0 \%$ \\
\hline & Inteligencia & $4,7 \%$ & $2,8 \%$ \\
\hline & Mejora & $20,9 \%$ & $2,8 \%$ \\
\hline & Natural & $2,3 \%$ & $2,8 \%$ \\
\hline & Necesario & $2,3 \%$ &, $0 \%$ \\
\hline & Oportunidad & $11,6 \%$ & $2,8 \%$ \\
\hline & Precisión &, $0 \%$ & $2,8 \%$ \\
\hline & Solución & $4,7 \%$ & $8,3 \%$ \\
\hline & Útil & $2,3 \%$ &, $0 \%$ \\
\hline & Ventaja & $2,3 \%$ & $2,8 \%$ \\
\hline & Versatilidad &, $0 \%$ & $2,8 \%$ \\
\hline
\end{tabular}

Tabla 7.13 Imágenes y valores positivos por periódico 
Al comparar los datos por periódico vemos que las frecuencias son parecidas, aunque hay algunas imágenes $y / 0$ valores que sólo encontramos en uno de ellos. Las que se presentan exclusivamente en el diario El País son accesibilidad, adecuación, beneficio, calidad, cambio, efectividad, eficacia, fiabilidad, precisión y versatilidad. Por su parte, solamente aparecen en El Mundo confianza, innovación, necesario y útil.

Revisemos algunos ejemplos de estas imágenes y valores:

Mejora:

En las pruebas más recientes, realizadas a principios de este año, Nagle pudo usar el pensamiento para abrir y cerrar una prótesis artificial de mano y mover un brazo robótico para coger caramelos de la mano de una persona y dejarlos en otra. También ha mejorado sus habilidades en los juegos de ordenador practicando con el Pong. (El Mundo 2005)

Facilitar:

Otros detalles, como las teclas en relieve o el altavoz de alta potencia, facilitarán el manejo a los usuarios. Se comercializará en los puntos de venta de Telefónica Móviles y en las oficinas de la ONCE y su precio será de 400 euros. (El Mundo 2004)

Independencia:

En definitiva se trata del sorprendente mundo de las comunicaciones e interacciones entre humanos y ordenadores, o si se quiere entre la inteligencia natural y la artificial, cuyas aplicaciones se centran fundamentalmente en proporcionar un cierto grado de independencia a las personas con distintos grados de parálisis. (El País 2005) 
Parte II. Aplicación de un modelo de cultura científico-tecnológica en las personas con discapacidad

Oportunidad:

Una de las últimas creaciones ha sido la de un robot que tiene su fuente de energía en un músculo animal, un híbrido entre tecnología y biología que tendría múltiples posibilidades para los paralíticos. (El Mundo 2005)

Apoyo:

Se espera también poder aplicar esta tecnología para restaurar cierto control de movimientos en pacientes con parálisis o lesiones de la médula espinal. (...) Serruya añadió que el grupo de científicos ha creado una compañía para desarrollar un aparato médico que ayude a personas con parálisis. (El Mundo 2002)

Comunicación:

Durante el resto de su vida, el ordenador de su silla de ruedas ha sido su única forma de comunicarse con el mundo. Su cerebro, sin embargo, sigue sin tener el más mínimo problema para comunicarse con el universo. Hawking es uno de los físicos teóricos contemporáneos más brillantes, y ha construido la mayor parte de su trabajo elevándose sobre los hombros de dos gigantes: Albert Einstein y Richard Feynman. (El País 2002)

Solución:

El proyecto de fin de carrera de César Mauri, de la URV, propone una solución que permita el acceso a la informática a personas con discapacidades en las extremidades. (El País 2002)

Accesibilidad:

Ciertamente, en la actualidad, tanto la telefonía móvil como Internet nos ofrecen un sinfín de posibilidades. Si además tenemos en cuenta su accesibilidad -es emocionante ver a los 
adultos cómo se introducen en eso del correo electrónico en cibertecas públicas-, podremos decir que estamos ante un elemento democratizador de la sociedad. (El País 2004)

\section{Avance:}

No es éste el único avance conocido ayer en el ámbito de la visión. El británico Gislin Dagnalle acaba de presentar un ojo biónico, que asegura que permitirá ver a los ciegos, al menos hasta poder reconocer una cara, según informa la BBC. Se trata de un chip que se coloca detrás del ojo y está conectado a una minicámara de vídeo insertada en los cristales de las gafas. Las imágenes captadas son enviadas al chip, que las traduce en impulsos eléctricos para que las pueda interpretar el cerebro. (El Mundo 2005)

\section{Calidad de Vida:}

Pero si por un motivo me ha interesado el reportaje de la revista es por todo lo que las nuevas tecnologías mejoran la calidad de vida de las personas con alguna discapacidad. (El País 2004)

Inteligencia:

El más inteligente de los tres robots es el que ha sido desarrollado por el MIT. Bautizado oficialmente como Toddler (bebé, en inglés), no sólo tiene casi humano, sino que además es capaz de aprender a moverse. En menos de 20 minutos, el tiempo que tarda en dar unos 600 pasos, el androide ya es capaz de imitar a la perfección la forma de andar de los hombres. Además, reconoce el tipo de superficie por la que se desplaza y se adapta a ella. (El Mundo 2005) 
Parte II. Aplicación de un modelo de cultura científico-tecnológica en las personas con discapacidad

Beneficio:

En el futuro, los principales beneficiarios serán los discapacitados físicos, explica con cautela José del Rocío Millán, que acaba de recibir el Premio Salvà i Campillo 2001, de la asociación catalana de Ingenieros de Telecomunicaciones, al proyecto de investigación más destacado. El objetivo del proyecto $A B I$ (Adaptive Brain Interface, interfaz cerebral adaptable), promovido por la Comisión Europea, es demostrar que existe una tecnología que permitirá a las personas hacer mejor sus tareas. (El País 2002)

Natural:

Cuando se trata de prestar ayuda en un entorno doméstico, la apariencia amigable de una máquina facilita mucho la interacción y su aceptación. A una persona mayor o con discapacidades físicas le resulta más fácil dar órdenes a alguien que le recuerda a un asistente que no a una máquina impersonalizada. (El País 2004)

\section{Eficiencia:}

Los robots convencionales que andan sobre dos patas tienen que tener actuadores o motores en cada articulación y por ello su consumo es alto, explicó Ruina. El caso de referencia es el bípedo japonés Asimo, un robot convencional en este sentido. El ejemplar de Cornell es 10 veces más eficiente en consumo de energía por unidad de peso y distancia recorrida. (El País 2004)

Ventaja:

El nuevo trabajo es un paso adelante para conseguir que las personas con parálisis puedan mover un cursor valiéndose del pensamiento, lo que les permitirá manejar un ordenador, con 
todas las ventajas que proporciona la informática: correo electrónico, Internet, y otras funciones de movimiento de miembros robóticos. (El Mundo 2002)

Adecuación:

Los audífonos de última generación son casi todo menos un mero amplificador del sonido. En minúsculas carcasas de apenas un centímetro cúbico de volumen es posible encontrar dos micrófonos multidireccionales, un amplificador capaz de alcanzar 140 decibelios, un altavoz y un paquete de por lo menos cuatro chips de silicio que almacenan medio megabit de memoria que da cabida a programas informáticos que se ajustan automáticamente a distintos escenarios acústicos. (El País 2003)

Calidad:

Pilar Vázquez, madre de Alicia, una niña de ocho años, es rotunda: su objetivo es conseguir la "'"máxima normalización"'" de su hija. Su deseo es que participe "'"en el mundo en que vive y haga una carrera de acuerdo con sus aptitudes, a pesar de de ser sorda"'." Alicia, la hija de Pilar Vázquez, estudia 3o de Primaria en el colegio madrileño Tres Olivos y lleva un implante bilateral, es decir, uno en cada oído. "'"Ha sido una decisión familiar. He llegado a la conclusión de que si ya con uno tenía una buena calidad, con dos iba a ser mejor. Desde julio, Alicia oye con los dos, y para ella es mucho más cómodo. Un día se le acabó la pila del primero y dijo: 'Oigo más bajo'. No es una cuestión de volumen. Lo que sucede es que con los dos localiza mejor los sonidos"'"', sigue su madre." (El País 2005) 
Parte II. Aplicación de un modelo de cultura científico-tecnológica en las personas con discapacidad

\section{Cambio:}

Los sordos viven un encendido debate. Para muchos la sordera forma parte de su identidad y no es una estricta discapacidad. Al mismo tiempo, un nutrido grupo de niños y jóvenes oyen y hablan ya como si no lo fueran, gracias al implante coclear. Este dispositivo (un electrodo instalado en el oído interno y un aparato externo con micrófono y procesador electrónico) ha revolucionado su vida. (El País 2005)

\section{Confianza:}

Esta es la conclusión de una investigación estadounidense que reclama una mayor precaución a la hora de sustituir las tradicionales radiografías por el uso de las modernas técnicas de imagen en el diagnóstico de las molestias lumbares, un fenómeno que también se está produciendo en España. El motivo es que, según explican los autores del trabajo, tanto al médico como al paciente les ofrece mayor confianza el resultado de la exploración realizada con resonancia magnética (RM). (El Mundo 2003)

\section{Efectividad:}

También puede resultar efectivo para tratar otras enfermedades, principalmente la ceguera en las personas con diabetes, pero también se va a estudiar su uso en terapias contra la obesidad, fracturas óseas, algunos problemas dermatológicos y ciertas enfermedades neurodegenerativas, como el alzheimer o la esclerosis. (El País 2004)

Fiabilidad:

En este momento hay en España más de 3.500 implantados y 34 centros de la sanidad pública que efectúan esta operación. El número de operaciones de implante coclear es de 500 anuales, y 
con listas de espera en diversos lugares. Si fuera poco fiable no estaríamos en esta situación, o todos estamos locos. (El País 2004)

Innovación:

El éxito del innovador proyecto [prótesis intraocular] dependerá en buena medida de la colaboración de las nueve instituciones que se han implicado en el mismo. Además de las ya citadas, en el programa trabajan varios laboratorios del departamento de Energía de EEUU, que ha aportado seis millones de dólares a la investigación, dos compañías privadas californianas y otras dos universidades más estadounidenses. (El Mundo 2005)

Necesario:

El Plan Gerontológico del año 2000 marcaba como objetivo un índice del 12\% de población 'teleatendida'. El anteproyecto de Ley de Dependencia, actualmente en discusión, prevé potenciar este dispositivo asistencial con la creación de 800.000 nuevas plazas en los próximos años. "Como mínimo deberían tenerlo todos los que viven solos y los que residen con su familia pero son semiválidos [tienen alguna discapacidad]», dice Martínez Gómez. "Sólo en Reino Unido hay más de un millón de usuarios», compara Inmaculada Romero. (El Mundo 2005)

Precisión:

Por el momento, la personalización extrema no es posible, pero los audífonos digitales disponibles empiezan a acercarse a este objetivo. La idea que planea en la mente de los grandes fabricantes del sector no es sólo disponer de un instrumento capaz de reproducir exactamente los sonidos de un entorno, sino discriminar entre el llamado sonido útil y el ruido, ofrecer 
soluciones para distintos escenarios $y$, sobre todo, personalizar esas soluciones de acuerdo a las preferencias, hábitos o necesidades de cada individuo. (El País 2003)

Útil:

Investigadores de la Universidad de Brown (EEUU) han desarrollado un sistema para registrar, interpretar y reconstruir la actividad del cerebro que controla el movimiento de las manos, y han demostrado que, sólo con el pensamiento, se puede mover un cursor en una pantalla de ordenador para que llegue a un punto de destino, algo que el futuro podría ser de gran utilidad para las personas que sufren parálisis. (El Mundo 2002)

Versatilidad:

Las dificultades comienzan cuando el humano y la máquina tienen que encontrar un punto de entendimiento. Por este motivo los sistemas informáticos acaban siendo muy personales, es decir, programados para responder a las órdenes de una cabeza concreta. Cada tarea -ir a la derecha, subir o parar- activa zonas específicas de la corteza cerebral creando un dibujo eléctrico particular para cada acción. Pero "aunque existen mapas genéricos para todo el mundo, la actividad neuronal es fruto de las experiencias de cada individuo", explica Millán desde Suiza. De modo que para que el sistema funcione correctamente "tienen que aprender tanto la máquina como el individuo". (El País 2005) 


\section{Negativos}

Dentro de las imágenes y valores negativos, tenemos el "riesgo" asociado a las tecnologías en un $16,7 \%$ de las 18 alusiones encontradas en las noticias. Luego, a un mismo nivel están dependencia, dificultad, inadecuado, inseguridad y problema, todas con un $11,1 \%$ de las menciones. Finalmente, también con un mismo porcentaje $(5,6 \%)$ encontramos desigualdad, exclusión, ineficiencia, insuficiencia y molestia (Tabla 7.14).

\begin{tabular}{llc}
\hline Imágenes y Valores & Total & 18 \\
& Riesgo & $16,7 \%$ \\
& Dependencia & $11,1 \%$ \\
& Dificultad & $11,1 \%$ \\
& Inadecuado & $11,1 \%$ \\
& Inseguridad & $11,1 \%$ \\
& Problema & $11,1 \%$ \\
& Desigualdad & $5,6 \%$ \\
& Exclusión & $5,6 \%$ \\
& Ineficiencia & $5,6 \%$ \\
& Insuficiencia & $5,6 \%$ \\
& Molestia & $5,6 \%$ \\
\hline
\end{tabular}

Tabla 7.14 Imágenes y valores negativos en la prensa 
Parte II. Aplicación de un modelo de cultura científico-tecnológica en las personas con discapacidad

\begin{tabular}{llcc}
\hline & & \multicolumn{2}{c}{ Periódicos } \\
\cline { 3 - 4 } & & El Mundo & El País \\
\hline $\begin{array}{l}\text { Características y } \\
\text { Valores Negativos }\end{array}$ & Total & 8 & 10 \\
& Dependencia &, $0 \%$ & $20,0 \%$ \\
& Desigualdad &, $0 \%$ & $10,0 \%$ \\
& Dificultad & $12,5 \%$ & $10,0 \%$ \\
& Exclusión &, $0 \%$ & $10,0 \%$ \\
& Inadecuado &, $0 \%$ & $20,0 \%$ \\
& Ineficiencia & $12,5 \%$ &, $0 \%$ \\
& Inseguridad &, $0 \%$ & $20,0 \%$ \\
& Insuficiencia & $12,5 \%$ &, $0 \%$ \\
& Molestia & $12,5 \%$ &, $0 \%$ \\
& Problema & $12,5 \%$ & $10,0 \%$ \\
& Riesgo & $37,5 \%$ &, $0 \%$ \\
\hline
\end{tabular}

Tabla 7.15 Imágenes y valores negativos por periódico

La diferenciación por periódico muestra que, al igual que con los positivos, hay imágenes y/o valores negativos presentes en sólo uno de los diarios estudiados. Es así como tan sólo las visiones de la tecnología como generadora de "dificultad" y como un "problema" están presentes en ambos periódicos a la vez.

Para comprender mejor las imágenes negativas transmitidas por la prensa en relación a la tecnología examinemos algunos ejemplos:

Riesgo:

Pese a tratarse de una intervención segura, también tiene sus riesgos. (El Mundo 2004) 
Dependencia:

Hoy Carles vuelve a hablar gracias a una técnica natural: la voz esofágica o erigmofónica. Tenía otras opciones, como la prótesis laríngea y el laringófono, pero ambas son artificiales, lo que implica la permanente dependencia de un aparato y la voz resultante es menos natural. (El País 2005)

Dificultad:

Los usuarios ciegos podían, hasta ahora, utilizar los teléfonos móviles habituales, pero con serias dificultades. No tenían acceso a los mensajes de texto o a la agenda. Incluso las funciones más simples, como consultar el estado de la batería o la hora, eran completamente imposibles para ellos. (El Mundo 2004)

Inadecuado:

"La sordera no es un problema y los implantes cocleares no son buenos para los niños sordos". El psicólogo, lingüista y profesor estadounidense Harlan Lane defiende con pasión y convicción ideas que pueden generar asombro, en el mejor de los casos, o indignación, sobre todo si quienes las oyen son padres de un bebé sordo. Sin embargo, nadie discute su condición de experto, uno de los mayores, sobre la historia y la situación de la comunidad sorda. (El País 2004)

Inseguridad:

"La situación es mucho más grave en los países en desarrollo, donde millones de personas sufren problemas crónicos o discapacidades que hubieran podido evitarse, ello si no mueren por culpa de errores médicos, transfusiones de sangre sin garantías, fármacos falsificados o de calidad inferior a la norma y, sobre todo, prácticas inseguras en condiciones de trabajo 
precarias", dice Ebrahim Samba, director regional de la OMS para África. La OMS informa de que al menos un $50 \%$ del material médico no es de fiar, y un $77 \%$ de los casos de falsificación o mala calidad de los medicamentos se dan en países en desarrollo." (El País 2004)

Problema:

El Owasys 22C es un teléfono móvil muy diferente al resto. No está pensado para la mayoría de los usuarios, sino para una pequeña minoría que, hasta ahora, tenía muchos problemas a la hora de utilizar esta tecnología. (El Mundo 2004)

Desigualdad:

Esta organización pone de relieve que "el acceso a todos los productos y servicios es un derecho básico del consumidor, ya que existe discriminación si hay ciudadanos - personas mayores o con discapacidades- que no pueden usar los principales bienes [se refiere a aparatos tecnológicos] que se consumen hoy en día". (El País 2004)

Exclusión:

La ANEC promueve la iniciativa Design for All (Diseño para Todos): "Las consecuencias de un mal diseño en los productos electrónicos pueden ser graves barreras para muchos ciudadanos. Una de ellas es el conector que debe insertarse en el teléfono móvil para que se recargue", dice Giovannini. (El País 2004)

Ineficiencia:

Sin embargo, ningún material sintético desarrollado hasta el momento es capaz de responder de la misma forma que los 
tejidos vivos ante los cambios fisiológicos y bioquímicos del organismo. Buena parte de las prótesis construidas con estos elementos fallan pasados unos años, de modo que el paciente debe someterse a una nueva intervención para sustituir el implante. (El Mundo 2002)

Insuficiencia:

NAVEGADOR SONORO. El negocio, ésa es la clave. Gigantes como IBM ○ Microsoft llevan años investigando sobre formas alternativas de interacción entre el hombre y la máquina. Con la vista puesta en las personas con alguna minusvalía, han llegado a comercializar productos para el reconocimiento de voz o la navegación sonora. Pero sus prestaciones son limitadas. Otro ejemplo, el W3C, organismo que gobierna Internet, lanzó en 1999 las especificaciones que debían cumplir los navegadores por voz. Hace dos semanas, aún andaban con recomendaciones sobre la gramática. (El Mundo 2004)

Molestia:

Se queja de que, al agacharse, le molesta un poco la pila que le han instalado en el vientre, pero puede volver a pintarse las uñas. Con pulso firme. (El Mundo 2003) 
Parte II. Aplicación de un modelo de cultura científico-tecnológica en las personas con discapacidad

\subsubsection{Relaciones}

En el examen de la cultura científico-tecnológica en relación a las personas con discapacidad, vislumbrada a través de las noticias estudiadas, hemos visto cómo es la imagen proyectada de los discapacitados, cuáles son las visiones y los valores que se asocian a las tecnologías vinculadas a ellos y cuál es el papel que las PcD ocupan en el sistema de ciencia y tecnología.

Analicemos ahora cómo es la relación, en primer lugar, entre la imagen de los discapacitados en la prensa y su presencia en las noticias (Tabla 7.16).

\begin{tabular}{llccc}
\hline & & \multicolumn{3}{c}{ Presencia de las PcD en la noticia } \\
\cline { 3 - 5 } & & Parte & Párrafo & Toda \\
\hline Imagen de las & Total & 21 & 41 & 52 \\
Personas con & Generador & $4,8 \%$ & $7,3 \%$ & $1,9 \%$ \\
Discapacidad & Receptor & $23,8 \%$ & $24,4 \%$ & $59,6 \%$ \\
& SR & $47,6 \%$ & $43,9 \%$ & $5,8 \%$ \\
& Usuario & $23,8 \%$ & $24,4 \%$ & $32,7 \%$ \\
\hline
\end{tabular}

Tabla 7.16 Imagen de las PcD y su presencia en las noticias

Revisando la tabla, vemos que de las 52 veces en las que todo el texto periodístico tiene relación con la discapacidad en general o con alguna específica en particular; o si hay presencia de PcD desde el principio al final de la noticia, éstas aparecen como receptoras de tecnologías desarrolladas por científicos y tecnólogos en un $59,6 \%$.

Con un porcentaje mucho menor, $32,7 \%$, las $\mathrm{PcD}$ se muestran como consumidoras o usuarias de tecnologías. 
En el caso de estar representados por más de un párrafo dentro de la noticia, los discapacitados son mostrados en la mayoría de los casos, $47,6 \%$, sin relación (SR) destacable con las tecnologías. Como receptores y usuarios aparecen en un mismo porcentaje, 23,8\%.

Lo mismo sucede cuando la representación de las PcD dentro de la noticia se limita a un párrafo o a una frase, pero con menor porcentaje. Aparecen, sin vinculación con aparatos tecnológicos o técnicas en un $43,9 \%$ de las ocasiones y como receptoras o usuarias en un $24,4 \%$ cada una.

Observemos a continuación con qué imágenes y valores se relacionan las personas con discapacidad en sus roles de generadoras, receptoras o usuarias de tecnologías. En el caso de las visiones positivas, la única vez que un discapacitado es mostrado como generador, la tecnología se vincula a la idea de su función provechosa para la comunicación humana (Tabla 7.17).

\begin{tabular}{|c|c|c|c|}
\hline \multirow{2}{*}{ Imágenes y Valores Positivos } & \multicolumn{3}{|c|}{ Imagen de las Personas con Discapacidad } \\
\hline & Generador & Receptor & Usuario \\
\hline Total & 1 & 62 & 31 \\
\hline Accesibilidad &, $0 \%$ & $4,8 \%$ & $3,2 \%$ \\
\hline Adecuación &, $0 \%$ & $1,6 \%$ & $3,2 \%$ \\
\hline Apoyo &, $0 \%$ & $8,1 \%$ &, $0 \%$ \\
\hline Avance &, $0 \%$ & $4,8 \%$ & $3,2 \%$ \\
\hline Beneficio &, $0 \%$ & $3,2 \%$ &, $0 \%$ \\
\hline Calidad &, $0 \%$ &, $0 \%$ & $3,2 \%$ \\
\hline Calidad de Vida &, $0 \%$ & $4,8 \%$ & $3,2 \%$ \\
\hline Cambio &, $0 \%$ &, $0 \%$ & $3,2 \%$ \\
\hline Comunicación & $100,0 \%$ & $3,2 \%$ & $9,7 \%$ \\
\hline Confianza &, $0 \%$ &, $0 \%$ & $3,2 \%$ \\
\hline Efectividad &, $0 \%$ & $1,6 \%$ &, $0 \%$ \\
\hline Eficacia &, $0 \%$ & $1,6 \%$ & $3,2 \%$ \\
\hline Eficiencia &, $0 \%$ & $3,2 \%$ &, $0 \%$ \\
\hline Facilitar &, $0 \%$ & $8,1 \%$ & $12,9 \%$ \\
\hline Fiabilidad &, $0 \%$ &, $0 \%$ & $3,2 \%$ \\
\hline Independencia &, $0 \%$ & $11,3 \%$ & $6,5 \%$ \\
\hline Innovación &, $0 \%$ & $1,6 \%$ &, $0 \%$ \\
\hline Inteligencia & $0 \%$ & $3,2 \%$ & $3,2 \%$ \\
\hline Mejora &, $0 \%$ & $14,5 \%$ & $9,7 \%$ \\
\hline Natural &, $0 \%$ & $3,2 \%$ &, $0 \%$ \\
\hline
\end{tabular}


Parte II. Aplicación de un modelo de cultura científico-tecnológica en las personas con discapacidad

\begin{tabular}{lccc} 
Necesario &, $0 \%$ &, $0 \%$ & $3,2 \%$ \\
Oportunidad &, $0 \%$ & $9,7 \%$ & $9,7 \%$ \\
Precisión &, $0 \%$ & $1,6 \%$ & $3,2 \%$ \\
Solución &, $0 \%$ & $4,8 \%$ & $9,7 \%$ \\
Útil &, $0 \%$ & $1,6 \%$ &, $0 \%$ \\
Ventaja &, $0 \%$ & $1,6 \%$ & $3,2 \%$ \\
Versatilidad &, $0 \%$ & $1,6 \%$ &, $0 \%$ \\
\hline
\end{tabular}

Tabla 7.17 Imagen de las PcD y valores positivos de las tecnologías.

Por otra parte, hay 31 ocasiones en las que una persona con discapacidad representada como usuaria se relaciona con una idea positiva de la tecnología. La imagen más destacada es la de la función facilitadora de los aparatos tecnológicos y la técnica en la vida diaria de este colectivo, con un $12,9 \%$ de las menciones. Le siguen, con un $9,7 \%$ cada una, comunicación, mejora, oportunidad y solución.

La representación de los discapacitados como receptores de la tecnología es la que ofrece un mayor número de relaciones con imágenes y valores positivos de la técnica. De las 62 alusiones encontradas en las noticias, un $14,5 \%$ tiene conexión con la idea de la tecnología como elemento esencial para la mejora ya sea de las condiciones de vida, en general, o de la salud, en particular. En segundo lugar, está la tecnología como un factor de independencia (11,3\%), seguido de cerca por la imagen de ésta como un elemento que da oportunidades a las personas discapacitadas $(9,7 \%)$.

Pasemos ahora a examinar qué sucede con las imágenes y valores negativos. En este caso, también hay sólo una ocasión en la que una persona con discapacidad es presentada como generadora en el mismo texto periodístico donde se vincula a la tecnología con una visión negativa: la dependencia, o necesidad restrictiva de un aparato tecnológico (Tabla 7.18). 


\begin{tabular}{llccc}
\hline & & \multicolumn{3}{c}{$\begin{array}{c}\text { Imagen de las Personas con } \\
\text { Discapacidad }\end{array}$} \\
\cline { 3 - 5 } & & Generador & Receptor & Usuario \\
\hline Características & Total & 1 & 9 & 11 \\
y Valores & Dependencia & $100,0 \%$ & $22,2 \%$ & $18,2 \%$ \\
Negativos & Desigualdad &, $0 \%$ &, $0 \%$ & $9,1 \%$ \\
& Dificultad &, $0 \%$ & $11,1 \%$ & $9,1 \%$ \\
& Exclusión &, $0 \%$ &, $0 \%$ & $9,1 \%$ \\
& Inadecuado &, $0 \%$ &, $0 \%$ & $18,2 \%$ \\
& Ineficiencia &, $0 \%$ & $11,1 \%$ &, $0 \%$ \\
& Inseguridad &, $0 \%$ & $11,1 \%$ & $9,1 \%$ \\
& Insuficiencia &, $0 \%$ &, $0 \%$ & $9,1 \%$ \\
& Molestia &, $0 \%$ & $11,1 \%$ &, $0 \%$ \\
& Problema &, $0 \%$ &, $0 \%$ & $18,2 \%$ \\
& Riesgo &, $0 \%$ & $33,3 \%$ &, $0 \%$ \\
\hline
\end{tabular}

Tabla 7.18 Imagen de las PcD y valores negativos de las tecnologías.

En las 9 referencias en las cuales las PcD son vistas como receptoras de la investigación de terceros y la tecnología se ve con una connotación negativa, un tercio se asocia a la idea de riesgo y un $22 \%$ a la de dependencia.

En el caso de los usuarios, las imágenes negativas más importantes de la tecnología son la de ser generadora de dependencia, la calificación de inadecuado y de ser un problema para los discapacitados, con un $18,2 \%$ cada una de las 11 menciones identificadas en las noticias. 
Capítulo 8. Conclusiones 
- En el análisis de la revista Minusval se observa una mayor presencia de contenidos referidos a la tecnología que a la ciencia. Hay más menciones a los conceptos tecnológicos y, por ende, un mayor número de información cultural de ese ámbito. La cantidad de párrafos en los que encontramos este tipo de conocimiento es más de 4 veces superior a aquella donde hay información referida a la ciencia. Quienes desarrollan y quienes leen la revista tienen, por lo tanto, mayor contacto con el conocimiento tecnológico.

- Dentro de este tipo de información se advierte un predominio de contenidos externos tanto a la ciencia como a la tecnología; es decir, de aquellas imágenes, maneras de ver el mundo, normas y formas de comportamiento características de un grupo, actitudes y valores que si bien inciden en la ciencia y la tecnología no forman parte intrínseca de ellas.

- Los datos obtenidos en este estudio nos muestran que a la hora de transmitir conocimientos internos de ciencia o tecnología, en la revista Minusval es la información representacional la que ocupa el primer lugar. Es decir, aquella que, por ejemplo, describe las causas y síntomas de una enfermedad, el funcionamiento de las sinapsis neuronales o cómo la dopamina afecta al estado de ánimo. Posteriormente encontramos las reglas y pautas de comportamiento (prácticos) y, por último, los valores y/o preferencias (valorativos).

- Específicamente dentro de la cultura tecnológica transmitida por las páginas de esta revista sobresale la información extrínseca, por lo que podemos concluir que la revista Minusval centra su 
visión en la tecnología, y lo hace desde una perspectiva externa a los sistemas tecnológicos.

- Al analizar cómo se relacionan los diferentes tipos de información cultural tecnológica en los textos de esta publicación, se observa que es más probable que las representaciones intrínsecas a los sistemas técnicos se relacionen con conocimientos extrínsecos, sean éstos creencias, prácticas o valores. En cambio, en el caso de las prácticas y los valores tecnológicos intrínsecos, observamos que se presentan de una manera más aislada, siendo escasas las coincidencias en un mismo párrafo con la información extrínseca de la tecnología. Queda patente pues, que la revista Minusval, además de informar sobre conocimientos que atañen de forma directa al sistema tecnológico, ofrece interpretaciones o visiones externas, que desde la sociedad influyen indirectamente en dicho sistema. Por ejemplo, cuando define una ayuda técnica $o$ un aparato tecnológico como puede ser un teléfono móvil para sordos, no sólo informa sobre los aspectos técnicos de su diseño, estructura o funcionamiento; sino que también aporta una visión de los factores externos que afectan a su uso en el contexto social, como pudiera ser la incitación a utilizar determinados teléfonos celulares por motivos estéticos.

- Después del análisis de la cultura científico-tecnológica de la revista Minusval destaca la supuesta falta de valoraciones, apreciaciones y preferencias significativas para el uso y desarrollo de las tecnologías. Decimos "supuesta" porque, si bien a pesar de la escasez de menciones explícitas a valores hay numerosas representaciones que conllevan un valor en su significado. En el estudio de los textos de esta publicación hemos identificado una presencia mayoritaria de referencias que transmiten una imagen 
positiva sobre las técnicas y los aparatos tecnológicos presentes en la revista (68\%). El porcentaje sube a un $81 \%$ si a las imágenes reconocidas como positivas sumamos las imágenes o valores que se desean, esto es aquellas que no se reconocen como propias de las tecnologías en un momento determinado, pero que se anhela que las tuvieran.

- La imagen positiva más destacada en relación a las tecnologías es la de "facilitar", esto es, son presentadas como un factor o elemento que hace fácil o posible la ejecución de algo o la consecución de un fin para las personas con discapacidad, en particular, y para la sociedad, en general.

- También sobresale como positivo en las tecnologías el valor de la "Accesibilidad". En los diferentes textos es posible encontrar la idea de la accesibilidad como un valor intrínseco a la tecnología y ocasiones en las que la accesibilidad sigue siendo algo externo a la tecnología, una consecuencia del establecimiento de una relación entre el aparato y el usuario.

- Las características negativas encontradas más relevantes son las de "Exclusión" y "Brecha", es decir, la idea de la tecnología como un elemento segregador, de discriminación dentro de la sociedad. Esto llama la atención, ya que dentro de las imágenes positivas de la tecnología más mencionadas aparece la visión de elemento integrador y clave para lograr y afianzar la independencia de las personas con discapacidad en la sociedad en un porcentaje nada desdeñable. Observamos, por lo tanto, la convivencia de imágenes contradictorias entre sí que nos demuestran la existencia dentro del colectivo de personas con discapacidad del mismo debate sobre los efectos positivos o 
negativos que la tecnología tiene para el ser humano que se advierte en la sociedad en general.

- En cuanto a las imágenes y valores deseados encontrados en Minusval para las tecnologías, el hecho de que el mayor número de alusiones sea a la "Accesibilidad", a pesar de ser también el principal valor positivo reconocido como presente en las tecnologías, nos habla de una clara necesidad no cubierta aún para las personas con discapacidad.

- Al analizar los aparatos y las técnicas por grupos, observamos que dentro de la Informática es Internet la tecnología que más se asocia a valores positivos, seguida, por el Ordenador y la Web. En términos generales la imagen que destaca en este grupo es la de facilitar. Sin embargo, esta imagen convive con la idea de la informática como un elemento de exclusión y de que es necesaria mayor accesibilidad.

- La Telefonía, por su parte, se relaciona con los conceptos positivos de facilitar, útil e independencia. La imagen negativa la da nuevamente la noción de exclusión y la de ser demasiado cara. A este grupo de tecnologías también se les pide más accesibilidad.

- El grupo de Tecnologías Específicas cuenta del mismo modo que los anteriores con una mayoritaria imagen positiva, destacando la de ser un elemento que facilita la consecuciones de diferentes fines. La cara negativa la presentan las ideas de exclusión, dificultad y caro. Finalmente, se desea que estas tecnologías brinden más independencia a las personas con discapacidad. 
- Respecto al análisis de los diarios El País y El Mundo, advertimos que el peso de la cultura científico-tecnológica, dentro del total de noticias publicadas por los dos periódicos, corresponde a un $3,82 \%$. Por su parte, el de la discapacidad dentro de la información de ciencia y tecnología es menor, alcanzando tan sólo el 2,46\%.

- Es importante destacar que a pesar de la baja representación de la discapacidad en las noticias de ciencia y tecnología, cuando aparecen, las personas con discapacidad lo hacen con un papel protagonista dentro de los textos; como lo demuestra el porcentaje acumulado de aquéllos en los que las PcD tienen una figuración total o parcial (63\%), en comparación con las noticias dónde sólo figuran en un párrafo o en una frase.

- Al contrario de lo observado en la revista Minusval, en la prensa se distingue un claro predominio de temas científicos, sobre los tecnológicos, el $60 \%$ corresponde a información científica y $40 \%$ restante a conocimiento tecnológico.

Reconociendo el tipo de información cultural transmitida, vemos que ambos periódicos ofrecen principalmente contenidos representacionales intrínsecos. Esto pone de manifiesto una clara labor de entrega de conocimientos científicos en esta clase de noticias relacionadas con la discapacidad, es decir, realizan una labor divulgativa de la información científica hacia la sociedad.

- La principal imagen de las personas con discapacidad que encontramos en los textos periodísticos es la de receptoras, destinatarias de tecnologías desarrolladas por científicos y tecnólogos. En segundo lugar, y prácticamente a un mismo nivel, 
se advierte a las PcD como si no tuvieran ninguna relación con la tecnología además de como consumidoras y usuarias de éstas. Por último, en un porcentaje mínimo (4\%) se advierte la presencia de una imagen de las PcD como un agente activo en el sistema científico-técnico (generador).

- En la prensa, al igual que en la revista Minusval, destaca la imagen positiva que se tiene de la tecnología, ya que el $80 \%$ de las imágenes identificadas en los textos corresponde a visiones positivas de la tecnología. Destaca la idea de la tecnología como fuente de mejora para las personas con discapacidad y que facilita las acciones y el desenvolvimiento en la vida diaria.

- Las imágenes y valores negativos relacionados con la tecnología en los periódicos sólo llegan al 18\% de las identificadas. La más importantes es la idea de riesgo, seguida de dependencia, dificultad, inadecuado, inseguridad y problema; todas con una mínima representación. 
CONCLUSIONES GENERALES. UNA MIRADA GLOBAL 
Al comenzar este trabajo señalábamos la necesidad de estudiar mejor al público de la ciencia y, dentro de ese público en general, a cada grupo específico que forma parte del sistema. Con esta investigación hemos intentado contribuir, aportando nuestro granito de arena a la caracterización de los diferentes tipos de información que reciben y manejan las personas con discapacidad y a la comprensión de las relaciones bi-direccionales entre los discapacitados y el sistema de ciencia y tecnología. En definitiva, a dibujar con más claridad la cultura científicotecnológica de un grupo considerado minoritario en España. Creemos que una mayor cultura científica redunda en una mayor participación y permite a los discapacitados tomar decisiones, siendo parte activa del desarrollo científico-tecnológico.

El primer objetivo planteado fue el de conocer el estado de la producción científica española referida a las tecnologías vinculadas a la discapacidad. El panorama tiene sus luces y sus sombras. Por un lado, aunque en el marco legal se observan tendencias de apoyo a la investigación en este ámbito, no obstante, continúa siendo un área poco desarrollada en España. Además, hemos comprobado que los estudios científicos, las publicaciones y la divulgación de sus resultados son escasos. De las investigaciones sobre discapacidad, sólo el 10,84\% se refiere a la tecnología.

Por otra parte, a pesar de su reducido volumen, se advierte un leve pero progresivo aumento del número de publicaciones y presentaciones en congresos o conferencias en los últimos diez años. Sobresale el entorno educativo, por la cantidad de registros encontrados en esta investigación de esa área y porque sólo en ella se advierte la presencia de personas con discapacidad participando activamente en el sistema. La situación se ensombrece, sin embargo, con la realidad de que los temas de 
Cultura Científico-Tecnológica y Grupos Minoritarios. El caso de las Personas con Discapacidad

discapacidad y tecnología son tratados a nivel de literatura gris, difundidos a través de canales que no permiten certificar su calidad científica mediante un método riguroso.

Otro de los objetivos trazados fue el de aplicar a un grupo específico el modelo de cultura desarrollado por Miguel Ángel Quintanilla. Hemos buscado conocer con qué tipo de información cultural cuentan las personas con discapacidad y cómo se relaciona, se conforma y presenta este conocimiento en la sociedad. Gracias al examen que hemos realizado de los contenidos de la revista Minusval, publicación dirigida a discapacitados, profesionales y entidades que trabajan en favor de este colectivo, y de los textos periodísticos de ciencia y tecnología de los diarios El País y El Mundo, hemos reconocido y detallado el conjunto de rasgos - representacionales, prácticos y valorativos - que constituyen su cultura científico-tecnológica.

En la revista Minusval nos encontramos, esencialmente, con información relativa a la tecnología. El conocimiento transmitido corresponde a representaciones o creencias, que en su mayoría son extrínsecas, es decir, se refieren a los sistemas técnicos, pero no forman parte de éstos. En la prensa, en cambio, advertimos un claro predominio de contenidos científicos y que, si bien también son representacionales, corresponden a información científica intrínseca. Vemos, por lo tanto, que las noticias de ciencia y tecnología de los diarios estudiados se centran más en transmitir conocimientos científicos, mientras que quienes desarrollan y leen la revista Minusval tienen mayor contacto con el conocimiento tecnológico desde una perspectiva externa. Creemos que esta situación se podría explicar por las diferencias entre el modelo de periodismo de plena actualidad, que recurre a fuentes como las revistas científicas; y el de la Minusval, más cercano a las personas con discapacidad, que refleja sus intereses y preocupaciones. 
Al iniciar la investigación partíamos de la idea de que la cultura científica de las personas con discapacidad era eminentemente práctica; pero a la luz de los datos obtenidos podemos decir que el acento está puesto en las representaciones conceptuales o simbólicas, que, por un lado, en la revista Minusval son extrínsecas y, por otro, en la prensa, intrínsecas. La información práctica sí ocupa un lugar relevante, pero no es el principal.

Tema aparte es el de los resultados obtenidos al aplicar este modelo de cultura científico-tecnológica a los valores proyectados por los textos analizados. Como todo modelo, éste no deja de ser una figura, un reflejo de una compleja realidad. Luego, al momento de su aplicación a los textos periodísticos y a la revista, presenta algunas dificultades prácticas que al ser analizadas permiten perfeccionar la propuesta, otro de los objetivos del presente estudio.

Los conflictos más importantes surgen por la complejidad del lenguaje escrito, en este caso, que no presenta las ideas simplemente como blancas o negras, sino que ofrece una infinita gama de grises, otorgando riqueza a la descripción y concepción del mundo, pero, al mismo tiempo, dificultando su análisis.

Después de estudiar la cultura científico-tecnológica llama la atención la aparente falta de contenidos valorativos, apreciaciones y preferencias significativas para el uso y desarrollo de las tecnologías. Esto es así ya que al querer distinguir entre los diferentes tipos de información cultural presentes en un texto es preciso clasificar su contenido, con la necesaria simplificación a la que toda clasificación obliga. En la mayoría de los casos se opta, por lo tanto, a reconocer el carácter de representación de una idea expresada, obviando la valoración implícita que numerosas representaciones conllevan en su significado. 
Para subsanar esta debilidad hemos configurado un análisis en parte automático y en parte manual de las tecnologías y las imágenes y valores asociados a ellas en cada frase o párrafo. El examen realizado nos ha permitido descubrir la presencia de un abundante corpus de conceptos valorativos asociados a aparatos tecnológicos y a técnicas.

La conclusión más evidente que arroja este análisis es que existe una imagen positiva de las tecnologías en su relación con los discapacitados, tanto en la revista Minusval como en ambos diarios, idea respaldada por la presencia de imágenes y valores como el de ser un elemento que hace fácil o posible la ejecución de algo o la consecución de un fin para las personas con discapacidad en particular y para la sociedad en general. Destaca también en los periódicos la idea de la tecnología como una fuente de mejora para las personas con discapacidad y asociada al valor de la independencia.

Hemos dejado aparte un concepto, muy presente en la revista Minusval, que abre las puertas a nuevas discusiones: la accesibilidad. En los textos revisados podemos encontrar este término como un valor intrínseco a la tecnología y otros en los que la accesibilidad es algo externo, una consecuencia del establecimiento de una relación entre el aparato y el usuario. Esta situación provocó cierta dificultad a la hora de calificarlo como valor incorporado o no incorporado al sistema técnico correspondiente, ya que la accesibilidad es a veces presentada como un requerimiento social, una preferencia externa al funcionamiento del sistema técnico. Sin embargo, vemos que esa consideración de la accesibilidad como algo preferible, conveniente o valioso ha llegado a afectar profundamente a algunas tecnologías en nuestros días. 
Cuando la valoración de algo como accesible o no accesible se presenta en relación a los objetivos y resultados de una tecnología, como en el caso de las pautas de accesibilidad a Internet, observamos que el requerimiento deja de ser externo y pasa a formar parte del sistema a través, por ejemplo en este caso, de una serie de normas de actuación que hacen que cierto producto tenga ese valor. Advertimos, entonces, que la accesibilidad ha pasado a ser un valor constituyente del diseño, producción y uso de un sitio web.

La situación descrita nos lleva a pensar en la necesidad de generar un modelo de la evolución de la información cultural tecnológica en el que se refleje con mayor claridad, en primer lugar, la transversalidad de los contenidos valorativos en las representaciones y normas de conducta, además de en la información valorativa estricta, y, en segundo lugar, la permeabilidad que se produce entre los valores externos y los internos de los sistemas técnicos. Sería conveniente contar con un modelo que refleje la relación dinámica que se desarrolla en este aspecto de la cultura tecnológica.

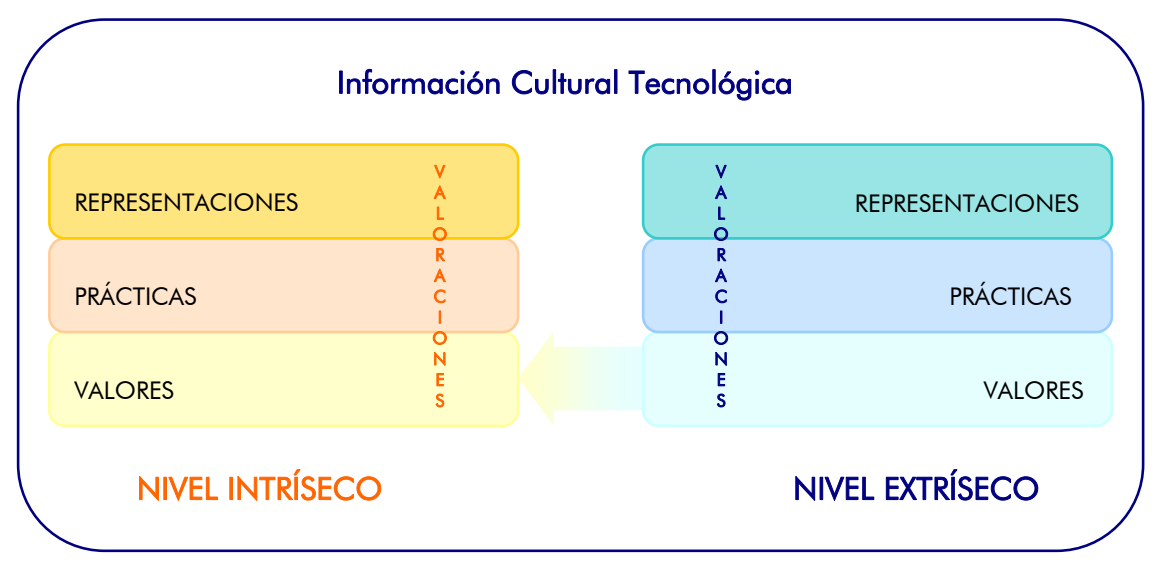

Fig. 9.1 Modelo de la Información Cultural Tecnológica Fuente: Elaboración propia 
El modelo que sugerimos en la figura 9.1 señala la presencia de valoraciones en cada uno de los tipos de información cultural referida a la tecnología (representaciones, prácticas o valores) que se transmiten mediante el lenguaje - escrito en este caso - en los textos analizados. La riqueza y complejidad del lenguaje en cuanto a significados y connotaciones hace patente la necesidad de realizar un análisis que interrelacione los contenidos culturales entre sí, para, de este modo, lograr reflejar mejor la realidad. Hemos observado, a lo largo del análisis, que el modelo teórico de cultura tecnológica aplicado al lenguaje escrito no puede separar abruptamente, aislando en compartimentos estancos, los diferentes tipos de conocimientos. Por otra parte, es preciso tomar en cuenta cómo los contenidos valorativos extrínsecos pueden pasar a ser incorporados a los sistemas técnicos. Se genera así una relación, ya no sólo de influencia, sino además de evolución teórica y práctica en la tecnología, a través de un traspaso de valores desde un nivel extrínseco a uno intrínseco, como señalábamos con el caso de la "accesibilidad", que bien pudiera aplicarse a otros.

Un ejemplo más en relación a lo que venimos diciendo, es el de la "usabilidad". Hace algunos años que este concepto se viene aplicando a los soffware o hardware informáticos, pero también a cualquier sistema o aparato tecnológico. La usabilidad surge de un valor, en principio extrínseco, referido a la facilidad o la dificultad de uso de una tecnología. Es decir, de la preferencia social de que las cosas sean fáciles de usar. La aplicación de este valor como algo intrínseco al sistema tecnológico ha llevado a que los proyectos de desarrollo de software lo consideren como una pauta a seguir en su diseño, distribución y uso. Además, existen ya pruebas de laboratorio para medir el grado de usabilidad de determinados sistemas. 
El "diseño para todos", en el que los términos accesibilidad y usabilidad son fundamentales, es un paradigma de una clara "intromisión" de los valores extrínsecos en los elementos incorporados a los sistemas técnicos. Una forma de diseñar que tiene en cuenta no sólo los factores estrictamente técnicos, sino que además depende de elementos del entorno social.

A la hora de analizar los valores presentes en un determinado mensaje, hemos observado la presencia de un traspaso progresivo de factores externos, de la esfera social, hacia las mismas estructuras del sistema científico-tecnológico. Una permeabilidad en los conceptos que abre nuevas interrogantes y requiere un estudio más profundo y que sobrepasa los límites de la presente investigación.

Pasando a las imágenes negativas identificadas, a pesar de su papel secundario en los textos, recalcamos el hecho de que los valores estén vinculados a la tecnología como elemento de discriminación, segregación, riesgo y dependencia para las personas con discapacidad. Visiones que entran en directa contradicción con las positivas y nos revelan la presencia, dentro de este colectivo, del mismo antiguo debate maniqueo de la supuesta "bondad" o "maldad" de las tecnologías.

Que la accesibilidad figure como el más importante dentro de los valores deseados para las tecnologías manifiesta la existencia de una necesidad no cubierta aún para las personas con discapacidad, idea que es reforzada por algunos valores negativos ya señalados.

Al analizar los diferentes aparatos tecnológicos y técnicas que aparecen en los textos se reconoce la presencia mayoritaria de las llamadas Tecnologías de la Información, esto es, aquellas que implican desarrollos informáticos, telemáticos y telefónicos en general. La imagen proyectada 
Cultura Científico-Tecnológica y Grupos Minoritarios. El caso de las Personas con Discapacidad

de ellas es positiva y destacan sus cualidades de facilitar, ser útil y favorecer la independencia. Es significativo que en el material analizado no haya una gran concentración de tecnologías específicas, sino que sean las de uso generalizado entre la población las más destacadas. A pesar de su escasa presencia, las tecnologías específicas tienen una imagen definida en los textos, son vistas como ayudas para hacer más fácil la vida de los discapacitados, pero que al mismo tiempo generan exclusión y dificultades.

También nos preguntábamos, en la gestación de este trabajo, cómo es la imagen que la sociedad tiene de la relación existente entre las personas con discapacidad y la tecnología. Para dar respuesta a estos interrogantes hemos echado mano de los periódicos, relevantes vehículos de transmisión de información a la sociedad.

Cuantitativamente se advierte un bajísimo peso de la temática de la discapacidad en las noticias de ciencia y tecnología, no llega al 2,5\%; noticias que de por sí también tienen una reducida importancia relativa dentro de los contenidos de los periódicos (3,82\%). A pesar de su limitada presencia, dentro de los textos en las que encontramos dicha temática, vemos que ocupa la gran parte o la totalidad del texto.

Una de las hipótesis de este estudio señalaba la idea de que las personas con discapacidad son vistas como receptoras de investigaciones y tecnologías desarrolladas por científicos y tecnólogos. Hemos descubierto que, en efecto, esa imagen se transmite en los periódicos, pero al mismo nivel de la que muestra a los discapacitados como consumidores y usuarios, no sólo receptores pasivos, de las tecnologías de cualquier índole. Por otra parte, la presencia de las PcD como agentes activos dentro del sistema científico-tecnológico es prácticamente insignificante. En los periódicos analizados no se proyecta apenas la imagen de los 
discapacitados como investigadores o creadores de nuevos conocimientos.

Al llegar a esta etapa de la investigación es posible que al lector le hayan asaltado algunas dudas; quizás también le surjan ideas para nuevos estudios que complementen éste. Por nuestra parte, consideramos que sería provechoso contrastar, mediante un estudio directo con entrevistas y cuestionarios, si los resultados obtenidos al analizar la revista Minusval y la prensa se corresponden con la percepción que los propios discapacitados tienen de su cultura. Por otro lado, creemos que se podría continuar la investigación del modelo de evolución de la tecnología en relación al traspaso de valores externos hacia niveles intrínsecos del sistema. La realización de un estudio más profundo del concepto de "accesibilidad", tal como podemos encontrar en la extensa bibliografía sobre "usabilidad", enriquecería la comprensión de este fenómeno.

Para finalizar, recordemos la frase de Einstein que en las primeras páginas de esta tesis nos inspira a continuar conociendo cada vez más de nosotros mismos y del mundo físico y social que nos rodea. Hemos conseguido respuestas a las preguntas que han dirigido esta investigación, pero como señalaba el ilustre físico siguen surgiendo cuestionamientos que nos instan a seguir adelante en el apasionante proceso de aprehender la realidad. 
REFERENCIAS BIBLIOGRÁFICAS 
ACCESO UnidAd de InVESTIGACIÓN DE LA UniversidAd de VAlenCIA 2000: Estudio sobre el Impacto de las Nuevas Tecnologías en las Personas con Discapacidad.

Aibar, Eduard \& Quintanilla, Miguel Ángel 2002: Cultura Tecnológica. Estudios de Ciencia, Tecnología y Sociedad. I.C.E. Universitat Barcelona / Horsori Editorial.

AUPA, Asociación de Usuarios de Prótesis y Ayudas Técnicas 2005: Ayudas Técnicas y Discapacidad. CERMI.

Bardin, Laurence 1977: Análisis de Contenido. Madrid: Akal Universitaria.

Barnes, Barry; Kuhn, Thomas S.; Merton, Robert K.: \& otros 1980: Estudios sobre sociología de la ciencia. Madrid: Alianza Editorial.

Beacco, Jean-Claude, Claudel, Chantal, Doury, Marianne, et al. 2002: 'Science in media and social discourse: new channels of communication, new linguistic forms'. Discourse Studies, 4(3), pp. 277-300.

Belenguer Jané, Mariano 2002: Introducción al Periodismo Científico. Sevilla: Padilla Libros Editores \& Libreros.

Bellacasa, Ramón Puig de la 1992: 'El impulso al desarrollo de ayudas técnicas para personas con discapacidad en la CEE'. En Diseño y producción de ayudas técnicas para personas con discapacidad en relación a los programas europeos. Sociales, Ministerio de Asuntos (ed). 
Bensaude-VInCENT, Bernadette 2001: 'A genealogy of the increasing gap between science and the public'. Public Understanding of Science, 10(1), pp. 99-113.

Berelson, Bernard 1952: Content Analysis in Communication Research. Glencoe (Illinois): Free Press.

Blanchet, A.; Ghiglone, R.; Massonat, J.; Trognon, A. 1989: Técnicas de Investigación en Ciencias Sociales. Datos, observación, entrevista, cuestionario. Madrid: Narcea.

Borgmann, Albert 2005: 'La tecnología y la búsqueda de la felicidad'. Revista CTS, 2(5), pp. 81-93.

Burns, T. W., OCOnnor, D. J., M., Stocklmayer S. 2003: 'Science Communication: A Contemporary Definition'. Public Understanding of Science, 12(2), pp. 183-202.

Calvo Hernando, Manuel 1999: 'La ciencia como material informativo. Relaciones entre el conocimiento y la comunicación, en beneficio del individuo y de la sociedad'. En Fayard, Pierre (ed) Madrid: Universidad de San Pablo/CEU. Facultad de Humanidades, Madrid.

Camí, J.; Suñén-Piñol, E.; Mendez-Vasquez, R. 2005: 'Mapa bibliométrico de España 1994-2002: Biomedicina y Ciencias de la Salud.' En Clin, Med (ed) (Barc): Institut Municipal d'Investigació Mèdica y Universitat Pompeu Fabra, Barcelona.

Cañas, Juan antonio 1994: Metodología de las Ciencias Sociales. Córdoba: Servicio de Publicaciones Universidad de Córdoba. 
CEAPAT 2006: 'Glosario'. En Madrid: Ministerio de Trabajo y Asuntos Sociales, Secretaría de Estado de Servicios Sociales, Familias y Discapacidad, IMSERSO; CEAPAT.

[http://www.ceapat.org/glosario.do\#d].

Cermi, Comité Español de Representantes de Personas con Discapacidad 2003: Nueva legislación sobre discapacidad en España.

Cermi, Comité Español de Representantes de Personas con Discapacidad 2004 : 'La discapacidad en la Constitución Europea'.

Cerml, Comité Español de Representantes de Personas con Discapacidad 2004 : La protección de las situaciones de dependencia en España.

CES, Consejo Económico y Social 2003: La Situación de las Personas con Discapacidad en España.

Colás Bravo, Pilar 1992: 'El análisis de datos en la metodología cualitativa'. Revista de Ciencias de la Educación, 152, pp. 521-539.

Comisión Interministerial de Ciencia y TeCnología 2003: Plan Nacional de Investigación Científica, Desarrollo e Innovación Tecnológica 20042007.

COTEC 1994: Un Análisis del Tratamiento de la Innovación Tecnológica en la Prensa Española (1992- 1993). Madrid: Cotec.

COTEC 1997: Documentos COTEC sobre Necesidades Tecnológicas. Sector de la Rehabilitación. Madrid: Cotec. 
COTEC 1998: Segundo Análisis del Tratamiento de la Innovación Tecnológica en la Prensa Española (1996- 1997). Madrid: Cotec.

COTEC 2003: Tercer Análisis del Tratamiento de la Innovación Tecnológica en la Prensa Española (2000-2001). Madrid: Cotec.

Cuevas Badallo, Ana 2004: 'La cultura tecnológica en la Corporación Cooperativa Mondragón (MCC)'. Revista CTS, 1(2), pp. 47-66.

Diéguez Lucena, A. 2000: 'íHubo siempre dos culturas?' Contrastes, 5 pp. 43-60.

fecyt, fundación Española para la Ciencia y Tecnología 2003: Percepción Social de la Ciencia y la Tecnología en España. Madrid: Fundación Española de la Ciencia y la Tecnología (FECYT).

fecyt, fundación Española para la Ciencia y Tecnología 2005: Percepción Social de la Ciencia y la Tecnología en España-2004. Madrid: Fundación Española de la Ciencia y la Tecnología (FECYT).

fecyt, fundación Española para la Ciencia y Tecnología 2007: 'Avance de Resultados de la Tercera Encuesta Nacional sobre Percepción Social de la Ciencia y la Tecnología (2006)', en http://www.fecyt.es/documentos/AVANCE_RESULTADOS 3 ENCUE STA PERCEPCIÓN SOCIAL CYT.pdf [Consultado en mayo de 2007]

fecyt, fundación Española para la Ciencia y Tecnología 2007: Percepción Social de la Ciencia y la Tecnología en España-2006. Madrid: Fundación Española de la Ciencia y la Tecnología (FECYT). 
Fellpe, Torrecilla Delgado 1995: 'Tecnología y deficiencia visual'. En La discapacidad en el siglo XXI. Plan de Acción. Una propuesta de futuro. Santander: Ministerio de Trabajo y Asuntos Sociales.

Fernández Cuesta, Carlos; Fuentes García, Felipe 1995: Curso de estadística descriptiva: teoría y práctica. Barcelona: Editorial Ariel.

Fog, LISBeTH 2004: 'Comunicación de la ciencia e inclusión social'. En Quark: Ciencia, medicina, comunicación y cultura, 32, pp. 36-41.

Fuller, SteVe 2003: 'La ciencia de la ciudadanía: más allá de la necesidad de expertos'. Isegoría, 28 pp. 33-53.

FundaCión BeLÉN 2004: Saber mirar: percepción social de las Ayudas Técnicas. Madrid: CEAPAT.

Fundation, National Science 2006: 'Science and Technology: Public Attitudes and Understanding'. In Science and Engineering Indicators 2006. Arlington: National Science Foundation.

García Ferrando, Manuel 1985: Introducción a la estadística en sociología. Madrid: Alianza Editorial.

Godin, Benoit; Gingras, Yves 2000: 'What is scientific and technological culture and how is it measured? A multidimensional model'. Public Understanding of Science, 9(1), pp. 43-58.

González Blasco, Pedro 1993: 'Los Españoles ante la Ciencia y la Tecnología'. En Revista Internacional de Sociología. Enero-Abril (4) pp. $233-270$. 
González García, Marta I.; lópez Cerezo, José A.; luján lópez, José L. 1996: Ciencia Tecnología y Sociedad. Una introducción al estudio social de la ciencia y la tecnología. Madrid: Editorial Tecnos S.A.

Harrison, Lawrense; Huntington, Samuel (ed) 2000: Culture Matters. How values shape human progress. New York: Basic Books.

Humanes, M. LUISA; IgARTUA, JuAN JOSÉ; RodríGuez, ISABEL, et al. 2001: 'La Información sobre Ciencia y Tecnología en la Prensa Española. Un Análisis de Contenido de los diarios El País y El Mundo'. En / Congreso Ibérico de Comunicación: La sociedad de la comunicación en el siglo XXI. Málaga.

IBV, Instituto de Biomecánica de Valencia 2003: Libro Blanco $/+D+l$ al servicio de las Personas con Discapacidad y las Personas Mayores.

IMSERSO 2003: // Plan de Acción para las Personas con Discapacidad 2003-2007.

IMSERSO 2004: Atención a las Personas en Situación de Dependencia en España, Libro Blanco.

INE 2001-2002: Encuesta sobre Discapacidades, Deficiencias y Estado de Salud: 1999. Madrid: Instituto Nacional de Estadística.

KripPendorfF, Klaus 2004: Content analysis: an introduction to its methodology. Thounsand Oaks, California: Sage Publications, Inc.

Kroeber, Alfred L. 1917: "The superorganic" American Anthropologist. Washington D.C. En Kahn, J.S., (ed.) 1975 El concepto de cultura: textos fundamentales. Barcelona: Anagrama. 
Lamo de Espinosa, Emilio 1996: Sociedades de Cultura, Sociedades de Ciencia. Ensayos sobre la condición moderna. Oviedo: Ediciones Nobel, S.A.

Lamo de Espinosa, Emilio; González García, José María; Torres Albero, Cristóbal 1994: La sociología del conocimiento y de la ciencia. Madrid: Alianza Editorial S.A.

LEN, Barton 1998: 'Sociología y discapacidad: algunos temas nuevos'. En Len, Barton (ed) Discapacidad y sociedad. Madrid: Ediciones Morata, S.L. y Fundación Paideia.

LÉVy-Loblond, Jean-Marc 2003: 'Una cultura sin cultura. Reflexiones críticas sobre la "cultura científica"'. Revista CTS, 1(1), pp. 139 - 151.

López Cerezo, José A.; Sánchez Ron, José Manuel (eds.) 2001: Ciencia, Tecnología, Sociedad y Cultura en el cambio de siglo. Madrid: Editorial Biblioteca Nueva.

Maltrás, Bruno; Quintanilla, Miguel Ángel 1995: Indicadores de la producción científica: España, 1986-91. Madrid: Consejo Superior de Investigaciones Científicas, CSIC.

MALINOWSKI, BRONISLAW 1931: "The culture" en Encyclopedie of the Social Science, vol. VI, Nueva York. En Kahn, J.S., (ed.) 1975 El concepto de cultura: textos fundamentales. Barcelona: Anagrama.

Martín Municio, Ángel 2003: 'Ambos son una cultura'. Revista CTS, 1(1), pp. 167-176. 
Merton, Robert K. 1977: La sociología de la ciencia, 1. Madrid: Alianza Editorial S.A.

Montero Becerra, Antonio 2007: 'La cultura científico-tecnológica en la prensa española. Un enfoque axiológico'. Salamanca: Universidad de Salamanca.

Morán Criado, José Manuel 1995: 'Nuevas aplicaciones tecnológicas para discapacitados'. En La discapacidad en el siglo XXI. Plan de Acción. Una propuesta de futuro. Santander: Ministerio de Trabajo y Asuntos Sociales.

Moreno Castro, Carolina 2004: 'Medios de comunicación e información científica'. Revista Sistema, 179 - 180 pp. 159-170.

Mosterín, Jesús 1993: Filosofía de la cultura. Madrid: Alianza Editorial.

MUNDO, EL 1996: El Mundo. Libro de Estilo. Madrid.

MuÑOz, Blanca 1989: Cultura y Comunicación. Introducción a las teorías contemporáneas. Barcelona: Barcanova.

PAís, El 1996: Libro de Estilo. El País. Madrid: Ediciones El País.

Polino, Carmelo 2001: 'Divulgación científica y medios de comunicación. Un análisis de la tensión pedagógica en el campo de la Comunicación Pública de la Ciencia'. En Instituto de Estudios Sociales de la Ciencia y la Tecnología. Thomas, Hernán (ed) Quilmes: Universidad Nacional de Quilmes.

Quintanilla, Miguel Ángel 1998a: 'Técnica y cultura'. Teorema, XVII (3) pp. 49-69. 
Quintanilla, Miguel Ángel 1998b: 'El Concepto de Cultura Tecnológica'. En Cultura Tecnológica e Innovación. COTEC.

Quintanilla, Miguel Ángel 2002: 'Tecnología y cultura'. En Cultura Tecnológica. Estudios de Ciencia, Tecnología y Sociedad. Barcelona: ICE/Horsori.

Quintanilla, Miguel Ángel 2005: Tecnología: Un Enfoque Filosófico y otros ensayos de Filosofía de la Tecnología. México: Fondo de Cultura Económica FEC.

RAE 2003: 'Diccionario de la Lengua Española'. En Real Academia Española.

Riffe, Daniel; F., Aust Charles; Lacy, Stephen R. 1993: 'The Effectiveness of Random, Consecutive Day and Constructed Week Sampling in Newspaper Content Analysis'. Journalism and Mass Communication Quaterly, 70 pp. 133-139.

Roca Dorda, Joaquín; Roca González, Joaquín; Del Campo Adrián, María 2004:

'De las Ayudas Técnicas a la Tecnología Asistiva'. En III Congreso Nacional de Tecnología, Educación y Diversidad (ed) Murcia.

Rodríguez, G.; GIL, J.; GarcíA, E. 1996: Metodología de la investigación cualitativa. Málaga.: Aljibe.

Sánchez Ron, José Manuel 1995: 'La Tercera Cultura'. Claves de razón práctica, pp. 42-49. 
Sarabia Alegría, José María 2000: Curso práctico de estadística. Madrid: Editorial Civitas.

Shamos, Morris 1995: "The myth of scientific literacy", New Bruncwick, New Jersey, Rutgers University Press.

Snow, Charles Percy 1964: The two cultures and a second look: an expanded version of The two cultures and the scientific revolution. New York: New American Library.

Tena, Juan 2003: 'La ciencia desapercibida'. Revista CTS, 1(1), pp. 189 196.

TYLOR, EDWARD B. 1977: Cultura primitiva. Los orígenes de la cultura. Madrid: Ayuso.

Vera LUnA, Pedro 1995: 'Actividades en tecnología de la rehabilitación'. In La discapacidad en el siglo XXI. Plan de Acción. Una propuesta de futuro. Santander: Ministerio de Trabajo y Asuntos Sociales.

Verdugo, Miguel Ángel 2004: 'Cambios conceptuales en la discapacidad'. En Desafío, II Congreso Internacional de Discapacidad Intelectual: Enfoques y Realidad: Un (ed) Medellín, Colombia.

Verdugo, Miguel Ángel 2006: Cómo mejorar la calidad de vida de las personas con discapacidad: instrumentos y estrategias de evaluación. Salamanca: Amarú Ediciones.

W.AA. 1997: Realizaciones sobre discapacidad en España. Balance de 20 años. Real Patronato de Prevención y de Atención a Personas con Minusvalía. 
Wonnacott, Thomas H.; Wonnacott, Ronald J. 1979, reimp. 1990: Introducción a la estadística. México: Limusa Editorial.

ZIMAN, JoHN 1972: El conocimiento Público. Un ensayo sobre la dimensión social de la ciencia. México D.F.: Fondo de Cultura Económica.

ZIMAN, JoHn 2003: 'Ciencia y Sociedad Civil'. Revista CTS, 1(1), pp. 177 188.

2003: 'Ley 51/2003, de 2 de diciembre, de igualdad de oportunidades, no discriminación y accesibilidad universal de las personas con discapacidad'. En Boletín Oficial del Estado.

2005: 'Anteproyecto de Ley de Promoción de la Autonomía Personal y Atención a las Personas en situación de Dependencia'.

2006: 'Ley 39/2006, de 14 de diciembre, de Promoción a la Autonomía Personal y Atención a las Personas Dependientes'. En Boletín Oficial del Estado. 
ANEXOS 
ANEXO 1

EJEMPLOS DE LA REVISTA MINUSVAL CLASIFICACIÓN POR CULTURA CIENTÍFICA Y TECNOLÓGICA

\section{Cultura Científica Representacional Intrínseca}

Hay evidencias científicas sobre la disminución de la discapacidad si se previenen las siguientes: hipertensión arterial, hiperlipemias, el tabaquismo, la obesidad, la depresión, los déficits de vista y oído, la artrosis, etc. P4:303

La inteligencia límite puede parecer, en principio, un concepto de fácil definición, especialmente si tenemos en cuenta la clasificación de la OMS, basada en el cociente intelectual: una persona con inteligencia límite es aquella cuyo cociente intelectual se sitúa entre 70 y 85 , es decir, justo por debajo de lo que se considera normal, pero tampoco englobado dentro del retraso mental. P5:112

Volviendo a las explicaciones científicas, ¿̇por qué el humor produce todos estos efectos positivos? Para José Elías, cuando nos reímos favorecemos la producción y liberación de sustancias bioquímicas como la dopamina, neurotransmisor que nos eleva el estado de ánimo, que puede resultar muy positivo para que personas con tendencias suicidas las abandonen. O la serotonina, tipo de endorfina con efectos calmantes y analgésicos y la adrenalina, que nos permite estar más despiertos y receptivos, proporcionándonos mayor creatividad. P7:822

En otras técnicas reparadoras las moléculas administradas, las células trasplantadas o los injertos no se mueven ni migran del lugar del implante, con lo que los axones, esas prolongaciones que arrancan de una célula nerviosa, no se regeneran más allá del implante y no consiguen reconectarse. P9:869

PROBLEMAS $Y$ APLICACIONES Sin embargo, en recientes declaraciones, el Dr. Adolfo Toledano, investigador científico del Instituto Cajal del Centro Superior de Investigaciones Científicas (CSIC), aseguraba que la utilización de embriones no es la única y mejor vía de investigación sino que debería ser conseguir células que tengan su origen en el mismo individuo y sean, por tanto, no susceptibles de rechazo. P9:852 
El profesor Manuel Nieto Sampedro, investigador del Consejo Superior de Investigaciones Científicas, CSIC, y miembro de la Unidad de Neurología Experimental del HNP afirmó en el curso para periodistas que "en los últimos 100 años se han propuesto muchas herramientas de reparación de la medula, pero pocas han resultado verdaderamente eficaces". P16:860

El síndrome de Tourette es un trastorno neurológico de origen genético, cuya característica esencial es la emisión de tics fónicos y motóricos de distinto tipo y complejidad. En muchos casos, los tics cursan con la manifestación de trastornos asociados, como el déficit atencional, la hiperactividad, alteraciones del sueño, impulsividad, el trastorno obsesivo compulsivo, depresión y oscilaciones del estado de ánimo. Estas alteraciones no conllevan por sí mismas un detrimento de la inteligencia o las capacidades intelectuales. P19:621

¿A qué se llama "clonación terapéutica"? A obtener células hES con propiedades modificadas según las necesidades. Por poner dos ejemplos: A) Modificaciones genéticas de células hES "naturales", cuando están en cultivo (sin necesidad de generar nuevos blastocistos), de forma que uno pueda cambiar sus propiedades para que produzcan, por ejemplo, una proteína que falte en el paciente receptor, o modificarlas para que el sistema inmune no rechace un injerto de ellas. Estas modificaciones se harían sobre las células, y el "aislamiento" de una nueva célula con propiedades genéticas determinadas daría lugar posteriormente a un cultivo de muchas células con las propiedades deseadas. Esto es lo que en ciencia se denomina aislar un clon (clon = grupo de células genéticamente idénticas). Esta clonación nada tiene que ver con hacer seres humanos. B) Otra posibilidad, distinta de la anterior, consistiría en utilizar técnicas de transferencia nuclear (la mal llamada "clonación terapéutica"). En este caso sí se trata de generar nuevos blastocistos y derivar de ellos nuevas líneas celulares cuyo núcleo y toda su dotación genética sea la que uno desea. Para ello, se transferiría el núcleo (sólo el núcleo, con dotación genética de un padre y de una madre) de una célula del paciente (por ejemplo de la piel) a un óvulo no fecundado al que previamente se le ha extraído su núcleo (que sólo tenía información genética de mujer de la que se obtuvo). Si a este óvulo al que se le trasplantó un núcleo de célula adulta (que ya tiene información de un padre y una madre) se le pudiese estimular para generar un blastocisto (en ausencia de un espermatozoide, algo que aún está en fase de experimentación en humanos),y de él se pudiesen aislar células hES, éstas tendrían las mismas propiedades genéticas del donante del núcleo, o sea, del paciente [salvo por parte de la información genética que reside en la mitocondria]. En esta situación (si fuese posible, y que por el momento no se ha conseguido de forma convincente con células humanas), se abren dos vertientes 
acerca de qué hacer con el blastocisto así generado. B.1) Lo indeseable, y que toda la comunidad científica rechaza:

Implantar ese blastocisto en el útero de una mujer, que actuaría como madre "de alquiler",y esperar a ver qué se genera, si se generase algo. La investigación llevada a cabo en los últimos seis años a raíz del descubrimiento de que era posible cultivar células troncales ("madre") de origen humano (human embryonic stem cells, células hES) ha originado una gran expectación social. Esto es debido a que el potencial curativo de las células hES para ciertas enfermedades, no tratables hoy en día, se supone que es tremendo. Estos tratamientos se llevarían a cabo mediante injertos de células sanas en órganos o tejidos dañados en el paciente. P21:457-458

La base genética del TA se sustenta en:

(1) la alta tasa de concordancia en los gemelos monocigóticos comparados con los dicigóticos (superior al 69\% vs 0\%); (2) el elevado grado de recurrencia entre hermanos de las personas afectadas (38\%, 50-100 veces mayor que el de la población general); (3) la mayor frecuencia de expresiones fenotípicas más discretas y variables de TEA en familiares de las personas con autismo; (4) el hallazgo de marcadores genéticos en casi todos los cromosomas, descritos en los análisis de ligamento del genoma completo realizados en familias con incidencia múltiple (varios hijos afectados); (5) la existencia de determinados fenotipos. P25:259

Las personas con enfermedades neuromusculares tienen como síntoma más importante la pérdida de fuerza. Una vez que comienzan a sentir sus efectos, tanto si se producen al nacer como si aparecen a cualquier edad, perduran toda la vida. Son enfermedades de origen genético generalmente manifestadas en un deterioro progresivo de los músculos o de los nervios destinados a ellos. Por suerte, estas enfermedades no producen ningún tipo de dolor ni afectan a la inteligencia aunque la pérdida de fuerza limita aspectos vitales de la persona y produce, especialmente, una sensación de dependencia hacia los demás. P29:34 


\section{Cultura Científica Representacional Extrínseca}

Somos conscientes de que el debate técnico o científico sobre políticas públicas de protección social está íntimamente relacionado con el debate sobre la política de control del gasto público y de estabilidad presupuestaria y del Sistema de la Seguridad Social. P2:140

"Nos debemos hacer a la idea - afirma Marcelo Palacios- que a no tardar mucho las enfermedades se tratarán con fármacos a la carta y que las tecnologías genéticas combatirán buen número de las enfermedades de mayor incidencia." Esos adelantos técnico-médicos incidirán directamente en la calidad de vida de las personas con discapacidad que envejecen. P4:192

La Bioética es un instrumento social orientado a impedir los posibles abusos (básicamente sobre el ser humano, pero también sobre la Biosfera) de las aplicaciones científico-técnicas. Sus postulados esenciales son la verdad, la autocrítica, la heterocrítica, la responsabilidad, la autonomía, la equidad y la dirimencia. P4:261

CAMBIOS CULTURALES Nos encontramos de frente, no sólo a innovaciones técnicos-científicas, sino a cambios culturales relevantes. A raíz de este gran cambio se produce la metamorfosis del imaginario contemporáneo. P6:307

Asimismo, el desarrollo científico y tecnológico introduce avances en la accesibilidad con aumento de la autonomía en la movilidad y con sistemas de control de entorno. P7:571

... reconocer que los avances científicos no pueden sustituir a la Lengua de Signos para las personas sordas. P9:719

Cuando se hizo público el nacimiento de la oveja Dolly, en el año 1997, se levantó una gran polémica por las consecuencias éticas y científicas que podía suponer la clonación reproductiva. Además de las repercusiones sociales no hay que olvidar las connotaciones religiosas que implica la utilización de embriones. P9:857

En la sociedad basada en el conocimiento, la democracia requiere ciudadanos y ciudadanas con ciertos conocimientos científicos y técnicos como parte de sus habilidades básicas. Ello supone que las personas necesitan una serie de habilidades y competencias para participar en la sociedad actual, y estas han debido ser desarrolladas al finalizar la formación escolar, pero deben continuarse a lo largo de toda la vida. P10:387 
La investigación científica, el desarrollo y la innovación tecnológica $(I+D+I)$ se configuran como potentes instrumentos de la política social. P12:228

Las sociedades más avanzadas incorporan el conocimiento como un factor de producción más, conocimiento que tiene su reflejo en métodos más eficaces de producción y organización, y en nuevos y mejores productos y servicios. En este sentido son estas sociedades las que han empezado a recoger los frutos de su apuesta por la investigación científica y el desarrollo e innovación tecnológica en forma de un mayor crecimiento económico y una mejora en la calidad de vida. P14:247

NUEVAS NECESIDADES Las cosas han cambiado y la longevidad en las personas discapacitadas supone un logro importante, por este motivo, cada vez son más las voces dentro de la comunidad científica, del campo profesional y de entidades que representan a las personas con discapacidad las que denuncian la falta de conocimientos para abordar este fenómeno desde diferentes dimensiones. Dentro de la investigación, tanto biomédica como sociológica, es necesario ver como afecta el envejecimiento a las personas que han vivido toda su vida, o una gran parte de ella, con una discapacidad atendiendo todas las tipologías existentes. Los profesionales sanitarios deben saber tratar adecuadamente estos procesos, qué necesidades presentan las personas afectadas y los recursos que necesitan. Pero no se debe olvidar a las familias, ni sus necesidades, porque son muchas las que viven de manera angustiosa la incertidumbre del futuro de sus hijos e hijas cuando ellas no puedan atenderlas. P15:126

Las personas con discapacidad estamos en contra del uso ideológico y eugénico que se pueda derivar de ese nuevo avance y lucharemos con uñas y dientes contra todo aquello que pretenda minusvalorar lo que todos tenemos, nuestra propia vida. La historia demuestra que el avance científico permite la cura de ciertas enfermedades, cada vez más, pero a pesar de las curas, el número de personas que tienen discapacidad sigue aumentando. P19:296

Es más, cuanto más avanza la ciencia, más enfermedades descubrimos, muchas de ellas de cura difícil. El cáncer, el SIDA, la depresión y otras muchas enfermedades eran desconocidas hace 200 años. Es previsible que el avance genético, además de curas, traiga el descubrimiento de nuevas enfermedades. P19:299

Hoy también tenemos la suerte de conocer algunos de los factores genéticos que pueden determinarlo, y hemos aprendido que no hay 
imposibilidad de relacionarse, sino problemas para comunicarse. Hoy, gracias al trabajo de los científicos y de los terapeutas y también, en buena medida, a los testimonios de las familias y de las propias personas afectadas, la imagen del trastorno autista parece adquirir nitidez y nos permite acercarnos mucho más a las necesidades de las personas que lo padecen. P25:157

Tal y como ha ocurrido con las costumbres de alimentación o higiene (primero desplazadas y luego integradas por el sistema sanitario) las costumbres de socialización y educación temprana tendrán que ser incorporadas a la ciencia emergente del desarrollo infantil y puestas a disposición de la población y de los nuevos cuidadores de la infancia a través de recursos expertos. P34:885

\section{Cultura Científica Práctica Intrínseca}

En la elaboración del Programa del Congreso de Oviedo se ha querido realizar una oferta diversificada que combinase una serie de sesiones interactivas y de índole eminentemente práctica, con presentaciones tanto de los últimos avances científicos en investigación e intervención como de experiencias e iniciativas que se están impulsando en diferentes ámbitos. P4:203

Científicos, neurólogos, pediatras, neurofisiólogos y terapeutas de todo el mundo se dieron cita en la ciudad de Bled, República de Eslovenia, para intervenir de forma activa en este $\mathrm{V}$ Congreso Internacional, con exposiciones y debates de alto nivel científico destinados a prevenir, detectar y tratar la parálisis cerebral que afecta a quince millones de personas a nivel mundial, la mitad con algún grado de retraso mental y un tercio con epilepsia. P4:674

La investigación ha sido publicada en la publicación especializada "Journal of Retractive Surgery". P6:713

Los científicos empezaban a sostener una hipótesis que se comprobaría en la práctica: el deporte es una parte esencial del tratamiento de recuperación de la discapacidad física y psíquica. Fue el doctor Ludwig Guttman quién creó el primer centro de rehabilitación para personas discapacitadas. P6:744-745

Durante este año y desde la Asociación Española para el Estudio Científico de Retraso Mental (AEECRM), los doctores Novell y Salvador (designado secretario de WPA) diseñaron y efectuaron un curso de formación sobre Salud Mental y Retraso Mental donde participaron más de mil psiquiatras de toda España. P10:727 
EFICACIA DE LOS TRATAMIENTOS ESPECIALIZADOS Todos los programas CRECER están sometidos a un control diario de los progresos de cada paciente, con lo que en cada momento se tienen un claro conocimiento del estado neurofuncional del paciente y de la eficacia de los métodos que se aplican. Este control se realiza tanto para la terapia física como para la terapia neuropsicológica, la logopédica y de comunicación, como para la ocupacional/ funcional a través de instrumentos de control y valoración especialmente diseñados para ello. Los datos globales obtenidos han sido publicados en revistas científicas y en congresos nacionales e internacionales (León-Carrión, 2000; León-Carrión, et al. 1999; Domínguez- Morales y León-Carrión, 2001). P35:743

\section{Cultura Científica Práctica Extrínseca}

En estos momentos estamos negociando con los agentes sociales las líneas básicas del Sistema de la Autonomía Personal y Atención a las Personas Dependientes. Además, estamos dialogando con las comunidades autónomas y el movimiento asociativo de las personas mayores y de las personas con discapacidad, así como con la comunidad científica. P2:24

Convocados por el ministerio de Trabajo y Asuntos Sociales a través del Real Patronato sobre Discapacidad, los Premios Reina Sofía 2002 tienen como objetivo recompensar una labor continuada llevada a cabo por un período de tiempo no inferior a diez años de investigación científica o de trabajo sanitario programado y evaluado científicamente cuyos resultados sean merecedores de esta distinción. P5:510

Premios CERMl.es $1^{\mathfrak{a}}$ edición La Fundación Víctimas del Terrorismo, Tele 5, Carrefour España, el científico Bernat Soria y la Dirección General de Costas, han sido galardonados con los Premios Cermi.es 2002 que concede esta organización para premiar a entidades que trabajan por la integración y participación de las personas con discapacidad. P10:651

El Príncipe hizo entrega de los Diplomas de los proyectos de investigación oncológica y ayudas contrato para investigadores de oncología otorgados por la Fundación Científica de la AECC (año 2003). P13:55

PORTUGAL Hay que promover los medios necesarios para combatir la discriminación y desarrollar protocolos de buen uso entre profesionales que trabajan con personas con enfermedad mental. Así lo manifestó desde la Asociación Médica Europea (EMA), su 
responsable en España, Juan Manuel Mendive, que organizó el Día Europeo de la Depresión para concienciar a la sociedad de esta enfermedad. En todos los centros de salud españoles tuvieron lugar unas jornadas, y en Madrid y en Barcelona se celebraron dos mesas redondas con representantes de las sociedades científicas más destacadas, así como de asociaciones de pacientes con depresión. P20:660

La prensa publica cartas al director, muy pocas noticias (descubrimientos científicos, delitos etc...), sobre todo en el apartado de salud. P21:141

La Asociación Americana sobre Retraso Mental (AAMR) ha otorgado al director del Instituto de Integración en la Comunidad, de la Universidad de Salamanca, el Premio internacional AAMR 2005.

Estos Premios se destinan a personas y grupos que han contribuido de forma excepcional en el campo científico de la discapacidad intelectual.

Miguel Ángel Verdugo, primer científico español que recibe este galardón concedido por la AAMR, organización científica y profesional de primera importancia e influencia mundial respecto a la discapacidad intelectual, recibirá el Premio en una ceremonia pública en el transcurso de la Reunión Cumbre sobre organizaciones norteamericanas dedicadas a la atención, formación e investigación en torno a la discapacidad.

Discapacidad en Washington D.C., en septiembre de 2005. P21:722725

Estos premios se organizan para recompensar una labor continuada de investigación científica o de trabajo sanitario programado y evaluado científicamente para contribuir a erradicar factores de riesgo que puedan afectar al futuro de la vida personal y social de muchas personas. Llevada a cabo en un período de tiempo no menor de 10 años, en el ámbito de la prevención de Deficiencias, a los que pueden optar investigadores del ámbito español y de países de habla española y portuguesa. P22:511

Convocatoria de Subvenciones I+D+i IMSERSO El Boletín Oficial del Estado de 1 de junio de 2005 ha publicado la Orden TAS/1588/2005 que establece las bases reguladoras de la concesión de las subvenciones para la realización de proyectos de investigación científica, desarrollo e innovación tecnológica, dentro de los Programas Nacionales de Tecnologías para la Salud y el Bienestar, y de las Ciencias Sociales, Económicas y Jurídicas, en el ámbito del Instituto de Mayores y Servicios Sociales (IMSERSO). P24:881 
Para que los Estados puedan poner en práctica estas propuestas, la OMS y sus asociados -entre los que se encuentra el movimiento asociativo de personas con discapacidad- les ofrecerán pleno apoyo, y han iniciado el proceso de elaboración de un "Informe Mundial sobre discapacidad y rehabilitación" en base a las mejores pruebas científicas disponibles. P25:662

La Obra Social de Caja Madrid - Información y divulgación de las enfermedades, dirigido a la sociedad en general, a los profesionales de la salud y a los propios afectados y familiares. - Fomento de la investigación, con la promoción de estudios científicos para avanzar en el diagnóstico y tratamiento de estas enfermedades. P26:760

El Comité Español de Representantes de Personas con Discapacidad (CERMI) ha convocado los "Premios CERMI.es" del año 2006, cuyo objetivo es reconocer la labor realizada por la sociedad en favor de los derechos, la participación y la plena ciudadanía de las personas con discapacidad y sus familias en siete categorías: "Integración laboral", "Investigación social y científica", "Acción social y cultural", "Acción en beneficio de las mujeres con discapacidad", "Medios de comunicación", "Mejor acción automática", e "Institucional". P30:652

La Ley de Lesiones Cerebrales Traumáticas de 1996 capacitó al secretario de Sanidad y Servicios Humanos —actuando a través del Director del Centro Nacional de Investigación de la Rehabilitación Médica, dentro del Instituto Nacional de la Salud Infantil y el Desarrollo Humano- para que realizara una "conferencia nacional de consenso sobre el tratamiento de las lesiones cerebrales traumáticas y temas de rehabilitación similares". Los Institutos Nacionales de la Salud organizaron una conferencia de dos días y medio de duración para evaluar la información científica existente sobre las prácticas de rehabilitación dirigidas a las personas con lesiones cerebrales traumáticas. P35:35

- Becas y ayudas a la investigación científica.

En el marco de las convocatorias anuales de becas y ayudas a la investigación de la Fundación MAPFRE Medicina, se convocan temas en el Área de Neurociencias. Así, por ejemplo, en la reciente convocatoria 2002-2003, se han señalado los siguientes:

- Neurotraumatología.

- Patología vascular cerebral.

- Neurooncología.

- Procesos neurodegenerativos.

- Nuevas aportaciones terapéuticas y tecnológicas en neurorrehabilitación.

- Programas y estrategias de rehabilitación neuropsicológica.

- Publicaciones. P35:146-154 
BREVES VI Premio Científico Documentos de Trabajo Social CASTILLA Y LEÓN El Colegio de Diplomados en Trabajo Social de Málaga organiza esta convocatoria dirigida a promover la producción teórica de los trabajadores sociales a través de una publicación de carácter científico siendo el plazo límite de presentación el 27 de septiembre de 2002. P38:638

\section{Cultura Científica Valorativa Intrínseca}

... prevenir con certeza científica en el 75 por ciento de los casos con la ingesta de ácido fólico. P21:75

Los programas actuales de investigación han planificado nuevos estudios para precisar con mayor rigor científico y réplica independiente de las hipótesis sobre otros posibles factores causantes del trastorno autista. P25:260

En todos y cada uno de los Simposium organizados por APNA, se ha contado con profesionales a nivel internacional y nacional que han compartido con interés, entusiasmo y rigurosidad científica, sus últimos descubrimientos en materia del autismo. P25:276

\section{Cultura Científica Valorativa Extrínseca}

Las altas tasas de dependencia en las personas mayores que estamos viviendo en España, no tienen porque mantenerse, pueden y deben disminuirse. Es posible, la evidencia científica así lo demuestra. P2:732

Se abre la posibilidad de alargar la vida humana hasta límites ahora difícilmente imaginables. Si los conocimientos se aplican con equidad, justicia y solidaridad transcurrirá en buenas condiciones de salud. P4:263

Y siempre teniendo en cuenta los principios básicos que deben regir la planificación en investigación científica y desarrollo e innovación tecnológica: generación de nuevos conocimientos y que éstos estén al servicio del ciudadano en forma de mejora del bienestar social. P14:255

Los principios generales que rigen el nuevo Plan Nacional están obviamente relacionados con las grandes directrices que orientan la política científica y tecnológica española, como son el estar al servicio del ciudadano y de la mejora del bienestar social, contribuir a la 
mejora de la competitividad empresarial, y por último contribuir a la generación de conocimiento. P14:263

UN TRASTORNO DE POR VIDA En los últimos años, el esfuerzo de familiares, organizaciones, e investigadores por acercarnos a una dimensión más real, razonable y científica del problema ha permitido un avance espectacular: hoy podemos decir que el autismo no es técnicamente una enfermedad, sino más bien un trastorno que va a durar toda la vida. P25:156

En ella se recogen e integran los trabajos científicos de los más prestigiosos autores a nivel internacional en el campo de la rehabilitación neuropsicológica. P35:882

\section{Cultura Tecnológica Representacional Intrínseca}

El mundo de las tecnologías de apoyo se extiende desde las prótesis (dispositivos que sustituyen la carencia de funcionalidades, por ejemplo un miembro artificial), a las órtesis (dispositivos que compensan y mejoran una funcionalidad presente pero debilitada, como un bitutor para pierna, un par de gafas, un audífono), a los sistemas de acceso al ordenador, a una miríada de dispositivos tecnológicos de ayuda en la terapia, en el aprendizaje de habilidades, de la movilidad, del cuidado personal, de las tareas domésticas, de la comunicación, del deporte y del tiempo libre. P1:2

Bastón de ultrasonidos. Basado en una técnica que imita el comportamiento de los murciélagos en la oscuridad para sortear obstáculos, el bastón ultrasonidos ha sido desarrollado por científicos de la Universidad inglesa de Leeds. P3:75

DISEÑO UNIVERSAL EN EUROPA Cristina Rodríguez-Porrero, directora del Centro estatal de Autonomía Personal y Ayudas Técnicas, CEAPAT, afirmó: "dentro de los objetivos del CEAPAT se encuentra el de fomentar el diseño universal". P3:511

El Centro de Ayudas Técnicas de Estocolmo (Hiälpmedels Center) es una exposición permanente, ubicada en el centro de la ciudad —calle Kungsgatan, 32- en la que se pueden ver productos especialmente diseñados, en su mayoría por empresas suecas, para las personas con discapacidad y las personas mayores. P3:635

Esta nueva técnica, inexistente hasta los años 70, consiste en una prótesis auditiva implantada quirúrgicamente en el oído interno que transmite las señales por micrófono externo y un procesador hasta llegar a un receptor y unos electrodos implantados en la cóclea. Una 
intervención con buenos resultados en adultos y en niños sordos postlinguales, y está sujeto a verificación en los niños sordos prelinguales. P3:649

Así, el teclado virtual ETSEDI, además de las ocho teclas virtuales, cuenta con 16 auxiliares en las que se irán presentando las distintas propuestas de palabras susceptibles de ser elegidas. De este modo las mil palabras más utilizadas en lengua española son seleccionadas por este sistema, y se puede ampliar a las diez mil más frecuentes así como generar "palabras nuevas" adecuadas al léxico de cada usuario. P1 1:893

Dentro del Programa lberoamericano de Ciencia y Tecnología para el Desarrollo (CYTED), el proyecto de nuevas tecnologías para discapacitados ha dado como resultado el desarrollo de nuevos medios técnicos basados en soportes electrónicos nuevos o adaptados, como diversos emuladores de periféricos y el detector Trébol, un innovador sistema de detección de obstáculos para las personas con discapacidad visual. P14:151

El hogar digital, como también se le conoce, dispone en sus estancias de terminales táctiles, sensores de movimiento y demás avances tecnológicos que ponen automáticamente en funcionamiento los aparatos electrónicos. P15:776

Las tecnologías a utilizar para hacer posible dicha interconexión son numerosas: inalámbrica (vía radio, infrarrojos o "Bluetooth"), cableado interno, línea telefónica o red eléctrica. P15:783

Los "Nokia" 3650 y 7650 están preparados para incorporar un software específico para invidentes, basado en la disponibilidad de un sintetizador de voz para acceso a las funciones básicas. Por su parte, los equipos móviles que incorporan tecnología GPRAS y sistema JAVA soportan aplicaciones de conversación de voz a texto que permiten visualizar en la pantalla del móvil la transcripción de la conversación.

P15:814

Sistema de localización personal Tormes. Tormes es un sistema de navegación personal basado en la tecnología GPS, que permite a las personas ciegas conocer su posición y guiarse a través de una ruta determinada. El dispositivo, fruto de la iniciativa auspiciada por la ONCE (Organización Nacional de Ciegos Españoles) y la empresa GMV Sistemas y con la colaboración de Tele Atlas, está integrado por un anotador Sonobraille, un teclado Braille, un sintetizador de voz, una base de datos cartográfica de diferentes ciudades y un receptor GPS. Tormes permite al usuario solicitar información y recibir datos sobre su posición, es decir, conocer el nombre de la calle y el rumbo 
a seguir, de forma que el sistema le guía a través del itinerario elegido. Como ventajas añadidas, Tormes asiste al invidente en rutas de nueva creación o elegidas con anterioridad; permite grabar y reproducir el camino recorrido, elemento de especial utilidad en actividades deportivas o en paseos por grandes espacios, hasta ahora, muy problemáticos para este colectivo; $y$, por último, permite trabajar en modo virtual desde el domicilio o la oficina, gracias a la utilización de los comandos de la aplicación para navegar por la cartografía como si se tratara de un mapa hablado. Mediante esta solución, es posible practicar futuros recorridos y editar rutas a fin de llegar a un punto determinado. P16:170

www.cermi.es Bastón para invidentes con las últimas tecnologías El bastón para invidentes Zingbee pretende aprovechar las etiquetas electrónicas de radiofrecuencia instaladas en el suelo de lugares públicos, como centros comerciales o estaciones de ferrocarril, para, con ayuda de las más innovadoras tecnologías de la información, sacar el máximo partido de dichos dispositivos con objeto de facilitar los desplazamientos a este colectivo. La iniciativa se enmarca en el proyecto sin barreras IT, lanzado en 2003 por las autoridades de Tokio a fin de utilizar las tecnologías existentes con objeto de concebir un sistema de localización y prevención de peligros para invidentes. Zingbee, en fase de pruebas, es fruto de este proyecto y alerta a sus usuarios de cruces o de la distancia de una escalera, mediante la transmisión inalámbrica al bastón de los datos en braille de las etiquetas electrónicas. Las informaciones procedentes de satélites GPS y bases cartográficas completan el dispositivo. P26:713

Teclado Braille para el ordenador. El nuevo teclado se conecta al puerto USB del PC, pudiendo funcionar a la vez que el teclado ordinario y facilitando cualquier tarea a las personas invidentes, siendo de especial utilidad a aquéllas con problemas motores que escribirán con mayor agilidad. El dispositivo combina, por primera vez, las teclas de función y desplazamiento de un teclado convencional con ocho teclas Braille que permiten escribir en cualquier idioma y está indicado para la edición de textos científicos y notación musical. P30:756 


\section{Cultura Tecnológica Representacional Extrínseca}

Pero, ¿̇cuántos son los productos de la tecnología de apoyo disponibles en el mercado europeo? El informe "Acceso a las tecnologías de apoyo en la Unión Europea", publicado por la Dirección de Empleo y Asuntos Sociales de la Comisión Europea, estima en más de 20.000 el número de ayudas técnicas disponibles actualmente en el mercado europeo, por un valor de negocio superior a treinta billones de euros. Sin embargo, ésta es una estimación muy aproximativa, obtenida sólo sobre la base de las intuiciones de los expertos. $\mathrm{P} 1: 4$

El elevado precio de las Ayudas Técnicas limita las posibilidades de asumir su pago o co-pago de forma individual por parte de la mayoría de los potenciales usuarios. Por esta razón es habitual encontrar a individuos que sufriendo la misma deficiencia padecen una limitación en la actividad (discapacidad) y una restricción en la participación (minusvalía) diferente en función de la ayuda técnica a la que han tenido acceso. P1:93

Somos conscientes de que el debate técnico o científico sobre políticas públicas de protección social está íntimamente relacionado con el debate sobre la política de control del gasto público y de estabilidad presupuestaria y del Sistema de la Seguridad Social. P2:140

Cuando nacemos con una discapacidad, o a lo largo de la vida la adquirimos, nuestra interacción con el medio que nos rodea depende de los facilitadores para nuestra actividad. Dependemos más que otros niños de esos apoyos para lograr hacer lo mismo; precisamos probablemente más ayudas técnicas que otros jóvenes para acceder a la sociedad de la información. Lo que sea de nosotros depende en gran medida de los medios que la sociedad ha puesto a nuestro alcance para participar como una persona más. P2:585

Pero también necesitaremos ayudas técnicas mediante elevadores que nos permitan acceder a los diferentes niveles de la casa; sistemas de control remoto para subir las persianas, si no podemos por nuestra artrosis; apagar luces sin necesidad de recorrer toda la casa; controlar la seguridad exterior e interior de la vivienda; pasamanos para desplazarnos por los pasillos; asideros para asearnos con seguridad...Todo ello con el fin de mantener nuestra independencia en el propio entorno, a buen seguro lleno de recuerdos que han llenado la historia de nuestra vida. P2:589

Una plataforma tecnológica que permitirá apoyar la vida independiente de personas con discapacidad severa, facilitar la 
gestión y provisión de servicios de las distintas organizaciones de servicios sociales y facilitar el trabajo de los asistentes personales, formales o informales, y por ende, el de los voluntarios. P3:227

"Nos debemos hacer a la idea - afirma Marcelo Palacios- que a no tardar mucho las enfermedades se tratarán con fármacos a la carta y que las tecnologías genéticas combatirán buen número de las enfermedades de mayor incidencia." Esos adelantos técnico-médicos incidirán directamente en la calidad de vida de las personas con discapacidad que envejecen. P4:192

Muchas personas necesitan hacer uso de ayudas técnicas desde edades tempranas, otras a lo largo de la vida, de forma continua o temporalmente. P6:178

Las Nuevas Tecnologías han abierto una puerta hacia la eliminación de barreras para acceder a la información, facilitar el aprendizaje de lenguas y promover la integración. Ejemplo de ello son: los diccionarios monolingües y bilingües en CD ROM, la subtitulación en la televisión, las ayudas técnicas para autonomía personal, internet como medio tanto para la comunicación e información como para la formación a través de los estudios a distancia. La lengua escrita es, sin duda, una herramienta necesaria para las nuevas tecnologías multimedia. P6:676

La tecnología está cambiando la relación hombre-objeto y hombremaquina. La última década se ha caracterizado, sin duda, por el fuerte desarrollo y la amplia difusión de nuevos materiales, las tecnologías electrónicas y las tecnologías informáticas. La consecuencia de esto ha sido la aparición de una nueva generación de objetos, los llamados "objetos tecnológicos", relacionados con los nuevos medios de comunicación: los ordenadores de bolsillo, Internet, móviles, MP3, notebook. P6:295

Asimismo, el desarrollo científico y tecnológico introduce avances en la accesibilidad con aumento de la autonomía en la movilidad y con sistemas de control de entorno. P7:571

Internet es una de las herramientas esenciales en el conjunto de las Tecnologías de la Información y la Comunicación, y las posibilidades que brinda en el ámbito de la comunicación, la información y los servicios para las personas con discapacidad son el objeto del dossier que hoy presentamos. P9:53

El concepto global de tecnologías al servicio de las personas con discapacidad y de las personas mayores es muy amplio y se relaciona con todo lo que supone innovación al servicio de la integración social, 
autonomía personal, independencia, salud y calidad de vida de las personas con discapacidad (alrededor de seis millones y medio en España) y de las personas mayores (cerca de siete millones de españoles tienen más de 65 años). P12:221

La investigación científica, el desarrollo y la innovación tecnológica $(I+D+I)$ se configuran como potentes instrumentos de la política social. P12:228

El I+D+I es un valor social, un bien colectivo que no puede dejarse en las manos exclusivas de los investigadores y tecnólogos. El I+D+I es una actividad transitiva, instrumental, que está al servicio de alguien o de algo y en cuyas coordenadas forzosamente han de integrarse la perspectiva del receptor o beneficiario, más allá de una consideración meramente de sujeto pasivo. P14:292

El desarrollo de la Sociedad de la Información puede considerarse la representación palpable de los efectos de la revolución tecnológica que vivimos en nuestros días y de los cambios que afectan a la forma de acceder al mercado de trabajo, a la educación, a las relaciones personales $y$, por todo tenemos en cuenta que el teléfono fijo tardó 50 años en penetrar masivamente en los hogares y que el teléfono móvil ha tardado tan sólo la décima parte, nos damos cuenta de la importancia que tiene que las nuevas tecnologías sean accesibles y asequibles para la inmensa mayoría de los ciudadanos. P1 4:384

Un hecho reconocido en la actualidad y en estas jornadas es que las personas con discapacidad constituyen un importante mercado en la mayoría de los sectores, sobre todo en el tecnológico, ya que una persona discapacitada utiliza apoyo en mayor medida que la población general. Por otra parte, está Internet que ha aumentado las posibilidades de comunicación para personas ciegas y sordas o con capacidad motora reducida. Incluso una persona con lesión medular, con un equipo adecuado, puede despeñar un trabajo. P16:151

"Con el avance de las nuevas tecnologías, cada vez hay más barreras y para más personas". P16:622

El caso de las personas que padecen discapacidades físicas es uno de los más habituales. El $53 \%$ de ellas son usuarios de ordenador. Del $47 \%$ restante, el $15 \%$ no lo es por problemas de accesibilidad, en gran parte porque desconocen las ayudas técnicas existentes. Este colectivo encuentra grandes problemas en el acceso al ordenador, que empiezan a solventarse con la disponibilidad de dispositivos específicos y con las opciones de accesibilidad que incorporan los programas informáticos más populares. P17:161 
$\mathrm{Ni}$ tan siquiera el tan pregonado advenimiento de la sociedad abierta y tecnologizada que celebraba el sistema ha traído una menor exclusión social y económica. P19:377

Creciente importancia de las nuevas tecnologías de cara al aprendizaje. P22:530

Pero, ¿̇cuántos son los productos de la tecnología de apoyo disponibles en el mercado europeo? El informe "Acceso a las tecnologías de apoyo en la Unión Europea", publicado por la Dirección de Empleo y Asuntos Sociales de la Comisión Europea, estima en más de 20.000 el número de ayudas técnicas disponibles actualmente en el mercado europeo, por un valor de negocio superior a treinta billones de euros. Sin embargo, ésta es una estimación muy aproximativa, obtenida sólo sobre la base de las intuiciones de los expertos. P26:180

AYUDAS TÉCNICAS. En cuanto a todo lo que son novedades técnicas para estos colectivos, precisa que son, por regla general, escasas, raras y efímeras en el mercado, y cuesta que lleguen a estar a su disposición. Además cree que "el sistema es manifiestamente mejorable en plazos, cuantías económicas y productos ofertados. P30:520

Teclado Braille para el ordenador. El nuevo teclado se conecta al puerto USB del PC, pudiendo funcionar a la vez que el teclado ordinario y facilitando cualquier tarea a las personas invidentes, siendo de especial utilidad a aquéllas con problemas motores que escribirán con mayor agilidad. El dispositivo combina, por primera vez, las teclas de función y desplazamiento de un teclado convencional con ocho teclas Braille que permiten escribir en cualquier idioma y está indicado para la edición de textos científicos y notación musical. P30:756

La tecnología puede favorecer y permitir la comunicación, la movilidad, las relaciones, el cuidado y las actividades de la vida diaria, y empieza a aplicarse con éxito en el ámbito de las personas mayores, con problemas de movilidad o con discapacidad. Gracias a la Domótica, personas que habitan en soledad y tienen problemas de movilidad, logran tener una mayor comunicación con el exterior, con los médicos o con el servicio de teleasistencia. P31:191

Los nuevos avances tecnológicos (trasportes medicalizados, unidades de cuidados intensivos y equipos de neurocirugía y neurotraumatología) salvan a un gran número de pacientes que hace 
unos años fallecían como consecuencia de estas circunstancias. P35:422

Por su parte, la Tecnología de la Rehabilitación (Assistive Technology en inglés) ha tenido gran influencia en la Interacción PersonaOrdenador. Muchos de los dispositivos de interacción no estándares que hoy en día son utilizados por un público más amplio fueron inicialmente concebidos para ser usados por las personas con discapacidad. Los sistemas de control de entorno inalámbricos (usualmente mediante rayos infrarrojos), el control del ratón mediante el seguimiento de la pupila (eye tracking) [Jacob95], o a través de la captación de algún tipo de señal eléctrica cerebral* [Lusted96] son algunos ejemplos de interfaces pensadas originalmente para las personas con discapacidad. P37:159

Las barreras en la accesibilidad dependerán más que nunca de los ojos con que se mire. Lo que unas escaleras implican para un usuario de silla de ruedas no significa nada para el compañero con sordera. El tamaño de la letra en los clasificadores no tendrá ninguna importancia para este usuario de silla de ruedas, pero su posición es muy importante. La persona que perdió sus manos tendrá dificultades para manipular objetos pequeños, pero ningún problema al usar la silla del despacho. Por tanto, los requerimientos deben entenderse como un conjunto global de problemas de donde extraer aquellos que tengan relación con el usuario concreto. Hay que tener en cuenta que las consideraciones sobre accesibilidad contenidas en la guía presuponen que no se está utilizando ninguna ayuda técnica que elimine las barreras de acceso al trabajo del usuario con discapacidad. P37:1261

\section{Cultura Tecnológica Práctica Intrínseca}

Para acceder a la Red Europea de Información sobre las Tecnologías para la Discapacidad y la Autonomía hay que ir al sitio www.eastin.info, elegir el idioma preferido entre los seis disponibles y navegar por el portal... P1:25

Igualmente ofrece demostraciones guiadas para grupos en las que se enseña la utilización de las ayudas técnicas tanto en el ámbito teórico como en el práctico. Los grupos deben realizar las reservas con anterioridad. P3:636

Las pautas pretenden ser compatibles con las tecnologías e instrumentos de diseño de la web más conocidos, y también con otros más recientes, tales como los nuevos navegadores con asistente digital y teléfonos WAP. Con este enfoque, en el que nada se da por 
definitivo, las pautas se convierten en una normativa cambiante y dinámica que pretende adecuarse o anticiparse a la evolución tecnológica más reciente. P4:387

Cada vez más proyectos de investigación y desarrollo tecnológico del Programa sobre las tecnologías de la sociedad de la información del Quinto Programa Marco utilizan las pautas desarrolladas por la Iniciativa de Accesibilidad a la Web. P4:432

MÉTODOS. Lo relevante de esta práctica de igualdad es diseñar productos, servicios y aplicaciones de inmediata utilización por la mayoría de usuarios potenciales sin necesidad de modificaciones; artículos fácilmente adaptables a diferentes usuarios; y hacerlo previa normalización de los interfaces para garantizar su compatibilidad con equipos especializados tales como ayudas técnicas para personas con discapacidad, etc. P4:611

La metodología aplicada para diseñar productos y servicios con los que conseguir lograr este objetivo es lo que se ha considerado "Diseño para Todos" y se compone de tres estrategias principales que son complementarias: - Diseño de productos, servicios y aplicaciones que sean utilizables por la mayoría de la población sin ninguna modificación. - Diseño de productos y servicios que sean fácilmente adaptables a diferentes usuarios (por ejemplo incorporando interfaces adaptables fáciles de modificar). - Diseño de productos que tengan interfaces estándar, en los que sea fácil conectar tecnologías de apoyo o dispositivos especiales. P6:278

Para ello, situaremos el cursor sobre dicho producto y lo activaremos mediante un click o pulsando intro. Esto nos lleva a una segunda pantalla (figura 3) que mostrará las características técnicas y/o una descripción. Esta página también hace una referencia a la base de datos de origen, posibilitándonos ir directamente a ese producto concreto pero en la base de datos nacional de la que proviene. P26:228

En lo que concierne al acceso a Internet, además de la utilización de las pautas WAI (Iniciativa para la Accesibilidad de la Web) desarrolladas por el Consorcio World Wide Web, se están impulsado varias ayudas técnicas que superan los obstáculos relacionados con el uso de lenguaje complejo, la ausencia de gráficos en los sitios y la falta de una organización clara: navegadores gráficos de ordenador, presentaciones gráficas y auditivas que completan el texto 0 reproductores multimedia. P20:499 
PAUTA 11. Utilizar las tecnologías y pautas W3C.

"Se tienen que utilizar las tecnologías propuestas por la W3C (de acuerdo con las especificaciones) y seguir las pautas de accesibilidad.

Donde no sea posible utilizar una tecnología W3C, o usándola se obtienen elementos transformados incorrectamente, se ha de proporcionar una versión alternativa del contenido que sea accesible".

Las actuales pautas recomiendan las tecnologías W3C (p. ej. HTML, CSS, etc.) porque incluyen características accesibles, además de estar desarrolladas en un proceso de laborioso consenso.

Muchos formatos no recomendados por W3C (por ejemplo, PDF, Schockwave, etc.) requieren ser vistos bien con plug-ins o aplicaciones autónomas. A menudo, estos formatos no pueden ser visualizados con algunos navegadores. P37:1091-1096

\section{Cultura Tecnológica Práctica Extrínseca}

TECNOLOGÍAS E INTERNET Hasta ahora ha faltado un observatorio informativo europeo que pudiera ofrecer a los agentes del sector (profesionales de los servicios socio-sanitarios y de la industria), y sobre todo a las personas más directamente interesadas en la utilización de las ayudas: (personas con discapacidad y sus familiares) información completa y digna de consideración sobre las posibilidades que ofrece el mercado en el área de las tecnologías al servicio de la discapacidad en la vida cotidiana. P1:05

En la elaboración de la red EASTIN, se ha prestado particular atención a la validación de los resultados que poco a poco se delineaban, a través de la interacción con tres grupos principales de interlocutores: los usuarios directos de las ayudas técnicas (personas con discapacidad y sus familiares), los profesionales de la sanidad y de los servicios sociales, la industria y la distribución de las tecnologías de apoyo. Con tal fin, se han reclutado en los distintos países tres grupos representativos de dimensión considerable 360 usuarios directos de las ayudas, 210 agentes sociosanitarios, 84 agentes de la industria y del mercado), a los cuales se les ha pedido, al tiempo que la red tomaba forma, que expresasen sus opiniones y sugerencias. P1:12

Asimismo, la presentación ante nuestro Ministro y la Secretaria General de Asuntos Sociales del Servicio de Información sobre Discapacidad, SID, fruto del Convenio entre el IMSERSO y la Universidad de Salamanca, un sistema informático para el acceso público e incorporación de datos sobre la discapacidad en las áreas de accesibilidad y ayudas técnicas, empleo, educación especial, integración escolar, prevención, protección económica, rehabilitación 
integral, salud y servicios sociales. Este nuevo Servicio, como Vd. sabe, ha merecido el Premio lbest 2001 a la calidad. P3:20

CONVENIO SOBRE NUEVAS TECNOLOGÍAS Promover el uso de las nuevas tecnologías de la comunicación en las relaciones entre las ONGs, y entre éstas y las Administraciones Públicas en el ámbito de la acción social, fue el objetivo del convenio firmado en julio de 2001 entre el ministro de Trabajo y Asuntos Sociales, Juan Carlos Aparicio, el presidente de la Agencia de noticias Europa Press, Asís Martín, y el presidente de la Fundación Chandra, José Martín. P3:517

LÍNEAS ESTRATÉGICAS Las directrices que vertebran el Plan de Familia contemplan una política fiscal y de rentas, la mejora de las prestaciones de la Seguridad Social por hijo a cargo, la conciliación de la vida familiar y laboral, y una política de vivienda. Favorecer el acceso de las familias a las nuevas tecnologías, la revisión del derecho de familia, el desarrollo de los servicios de orientación y mediación familiar y el apoyo a las familias en situaciones especiales, así como fomentar su participación social, el acceso a la cultura y elaborar una nueva ley de protección a las familias numerosas, completan el total de líneas estratégicas a emprender para hacer realidad el Plan. P4:52

Ana Birulés Ministra de Ciencia y Tecnología "Nadie debe ser excluido de los beneficios y de las ventajas que proporciona el avance tecnológico. Por ello la Unión Europea y el Gobierno Español asumen el compromiso de lograr una Sociedad de la Información para Todos, a fin de garantizar que las personas disfruten de una mayor autonomía y una mejor calidad de vida." Añadió que "los pasos para cumplir objetivos son las actuaciones del Ministerio de Trabajo a través del IMSERSO y del Ministerio de Ciencia y Tecnología, apoyando infraestructuras y el proyecto "diseño para todos"en el marco legal, destacando entre otros aspectos prioritarios la necesidad de profundizar los derechos de las personas con discapacidad en el acceso a redes y servicios de comunicación (información internacional y servicios de urgencia, entre otros)". P5:645

¿Existe suficiente legislación en los Estados miembros de la UE en materia de nuevas tecnologías en relación con la sociedad de la información para el acceso de las personas con discapacidad a los sitios públicos? En el contexto de la iniciativa e-accesibilidad, hemos creado un grupo de trabajo que está elaborando un informe sobre el ámbito de aplicación de la legislación existente. P6:84

SUBVENCIONES Y AYUDAS • ORDEN TTAS/128/2002, de 15 de enero, por la que, en el marco del Plan Nacional de Investigación Científica, Desarrollo e Innovación Tecnológica (2000-2003), se 
establecen las bases reguladoras de la concesión de ayudas para la realización de proyectos de investigación y desarrollo, dentro de la acción estratégica sobre envejecimiento y de la acción estratégica sobre tecnología sanitaria, vinculados a la tecnología de la rehabilitación, en el área del IMSERSO (BOE nํ 25, de 29 de enero). P10:540

Un certamen donde como viene siendo tradicional se entregaron los premios a la Innovación Tecnológica que premia servicios y equipamientos con los avances más importantes en ayudas técnicas para las discapacidades. P10:601

El Premio ASPID representa para el IBV un importante reconocimiento a los trabajos que viene desarrollando desde su creación en 1976 en lo relativo al estudio de la discapacidad, las ayudas técnicas y la tecnología de la rehabilitación. A lo largo de su historia, el IBV ha visto también reconocida su labor a través de premios concedidos por entidades como el IMSERSO, el Consejo Superior de Deportes o la Fundación Mapfre. P10:714

En total se han propuesto 23 medidas complementarias directamente dirigidas a mejorar la transferencia tecnológica y el conocimiento general sobre el sector tecnológico. Además se han descrito otras 22 medidas complementarias dirigidas a mejorar el apoyo social a la personas con discapacidad y a las personas mayores, así como también a los profesionales de atención socio-sanitaria en relación con el uso de las ayudas técnicas y el "diseño universal". P14:394

Esta Ley supone una mayor garantía de vuestra igualdad de derechos, y establece compromisos concretos para lograr que todos los edificios, todas las tecnologías y todos los servicios sean accesibles para las personas con cualquier tipo de minusvalía. P15:239

III PREMIOS INTERNACIONALES ONCE I+D EN BIOMEDICINA Y NUEVAS TECNOLOGÍAS Fomentar estudios científicos o desarrollos tecnológicos que faciliten la integración y normalización de personas ciegas o deficientes visuales, en áreas como ingeniería, inteligencia artificial, informática, telecomunicaciones, biotecnología y biomedicina, especialmente en investigación biomédica, genética, tecnologías de la información y comunicaciones, y otras áreas. Plazo: hasta el 31 de mayo 2004. P15:748

III PREMIO INTERNACIONAL I+D: BIOMEDICINA Y NUEVAS TECNOLOGÍAS Este galardón que otorga la ONCE bianualmente ha recaído en los equipos de las secciones de Genética Clínica y Oftalmología del Departamento de Estudios Clínicos de la Escuela de 
Medicina de Veterinaria de la Universidad de Pensilvania, coordinados por el doctor Gustavo Aguirre con la participación de la doctora Elena Vecino, (Dpto. de Biología Molecular de la Universidad de Salamanca) por su trabajo "Desarrollo y evaluación de nuevas terapias en enfermedades degenerativas de la retina". El objetivo del premio es fomentar estudios científicos o desarrollos tecnológicos que faciliten la integración de las personas ciegas o deficientes visuales. P21:867

Tanto el máster en tecnologías integradas como los títulos de especialista en sistemas interactivos de comunicación, análisis de medios de comunicación y software libre se llevarán a cabo gracias al acuerdo firmado entre la Secretaría de Estado de Servicios Sociales, Familias y Discapacidad, a través del Real Patronato sobre Discapacidad, la UNED y la Fundación ONCE. P23:589

Con un presupuesto de 550 millones de euros, financiará el coste de las ayudas técnicas tales como adaptar una vivienda, comprar un vehículo, contratar un auxiliar a domicilio o una ayuda en caso de tener animales domésticos. El total de esta prestación "universal" que también se otorgará a los niños por un periodo de tres años, se evaluará en función del "proyecto de vida" de la persona con discapacidad. Otra innovación de la ley es que se trata de un proyecto de vida definido con las personas afectadas en cada casa departamental de la discapacidad. P25:627

Elaboración de un Catálogo General de Ayudas Técnicas. El Catálogo deberá identificar la utilidad de las Ayudas Técnicas y evaluar en que grado cumple cada una de las Ayudas Técnicas con los objetivos propuestos por las Naciones Unidas en cuanto a la lucha contra la discapacidad. De esta forma los usuarios dispondrían de una referencia en cuanto a los tipos de Ayudas Técnicas existentes y la funcionalidad ofrecida por cada una de ellas. P26:278

Normas que regularán la accesibilidad tanto en las sedes de las administraciones públicas, como en el transporte, en los espacios públicos urbanizados y en las edificaciones, y facilitarán el acceso de las personas con discapacidad a las nuevas tecnologías y a los medios de comunicación, así como a los bienes y servicios en los sectores comerciales, turísticos, los servicios financieros y los seguros. P30:142 
Exposición de Ayudas Técnicas para discapacitados de Suecia y España, inaugurada por la Reina Silvia de Suecia el 14 de marzo. P32:242

Este artículo describe una experiencia de colaboración entre una pequeña empresa de sistemas y equipos mecánicos de precisión, un centro tecnológico especializado en computación y una organización no gubernamental de personas con discapacidad física para desarrollar soluciones a problemas de acceso en el transporte. El proyecto ha sido posible gracias a la subvención pública, en este caso del IMSERSO. P33:812

Dicha ley afecta a todas las agencias federales a la hora de desarrollar, publicar, mantener o usar todo tipo de tecnologías de información. Siguiendo los estándares basados en el Capítulo 508 (de la ley 29 U.S.C. '794d), las agencias deben ser capaces de proporcionar a personas discapacitadas contenido similar al que puede acceder los demás usuarios sin discapacidades. P37:1116

\section{Cultura Tecnológica Valorativa Intrínseca}

CONSIDERACIONES ESPECÍFICAS EN MATERIA DE ACCESIBILIDAD Y AYUDAS TÉCNICAS 1. Se hace imprescindible contemplar el nuevo enfoque que aporta la idea de accesibilidad universal donde lo relevante es concebir los objetos y el entorno de forma inclusiva, apta para todo tipo de personas. Además, los diseños universales permiten no estigmatizar a las personas con dependencia, con discapacidad, de edad avanzada u otras. En todo diseño ha de contemplarse la adaptabilidad desde el proceso de fabricación o construcción, lo que reduce considerablemente el esfuerzo y los costes ante el requerimiento de futuras adaptaciones. P2:325

Cuando son necesarias tecnologías específicas de apoyo, las ayudas técnicas han de ser accesibles y asequibles, con un diseño apropiado y atractivo. P2:326

Las personas con discapacidades y las personas de edad se enfrentan a toda una serie de barreras técnicas a la hora de acceder a Internet. La accesibilidad de éstos y de otros usuarios podría mejorarse considerablemente mediante una adecuada codificación en el momento de la creación de los sitios web y de concepción de sus contenidos, y mediante el respeto de unas normas simples de estructura y maquetación al diseñar las páginas web. Pero estas técnicas no son suficientemente conocidas y la mayoría de los diseñadores de sitios y los proveedores de contenido no las aplican. P4:369 
Internet cada vez es más valorado por las mujeres con discapacidad como una ayuda para acceder a la información Las nuevas tecnologías tiene que ser accesibles, asequibles, adecuadas, aceptadas, conocidas y aprovechadas, por y para las mujeres con discapacidad. P10:409

El IBV también presentó un estudio comparativo de cojines antiescara para la prevención de úlceras, una ayuda técnica de trascendencia ya que el $40 \%$ de lesionados medulares sufren escaras en el período comprendido entre el inicio de la lesión y el alta médica, lesiones que además son la puerta de entrada a microorganismos que pueden provocar cuadros infecciosos. Los resultados del estudio, realizado con pacientes reales, indican que los cojines de aire y de viscoelástico son los más adecuados. P14:155

Los procesos de $I+D+I$ deben venir contrastados por las personas con discapacidad destinatarias de los mismos, por lo que a lo largo de su curso han de establecer puntos críticos de utilidad, usabilidad y accesibilidad por parte de estas personas, que retroalimentarán a los investigadores y tecnólogos. P14:298

ACCESIBILIDAD La accesibilidad, como concepto en el campo del diseño, se puede considerar como el resultado de la aplicación de soluciones técnicas al diseño de nuestro entorno en cualquiera de sus distintas áreas (arquitectura, urbanismo, dispositivos, sistemas, productos, servicios y desarrollo de "software") que permita a los usuarios o consumidores manejar productos $y / o$ servicios con independencia de sus limitaciones funcionales. P1 4:223

Por otra parte, se destaca que la idoneidad y fiabilidad técnica del sistema de rampa y arrodillamiento lateral ha mejorado mucho en los últimos años... P28:337

Accesibilidad y usabilidad Los servicios domóticos deben ser accesibles para todos los usuarios, y su utilización debe resultar eficiente y fácil de aprender. P31:331

Fiabilidad Los usuarios de sistemas del hogar no deben ser expuestos a situaciones de riesgo por causa de la utilización de tecnologías de apoyo. Deben asegurarse niveles adecuados de disponibilidad y continuidad de servicio. Algunas acciones, llevadas a cabo por los usuarios o por el propio sistema de forma autónoma, pueden implicar riesgos. Los sistemas deben minimizar tanto la posibilidad de fallo autónomo, como la peligrosidad de situaciones causadas por una mala utilización. P31:346 


\section{Cultura Tecnológica Valorativa Extrínseca}

Es conocido el papel fundamental que juegan las ayudas técnicas en la recuperación de la autonomía de las personas con discapacidad, en la mejora de la sostenibilidad de la asistencia por parte de sus familiares, en abrir las puertas de la integración educativa, laboral y social. P1:1

Frente a este problema es el momento de reivindicar el derecho de las personas discapacitadas al acceso a las Ayudas Técnicas. P1:70

Asuntos como la valoración y la evaluación, las relaciones con la familia, la mejora de la calidad de vida, la coordinación sociosanitaria, las ayudas técnicas, aspectos de género, o el empowerment van a ser desarrollados por expertos de primera fila. $\mathrm{P} 4: 204$

La sociedad de la información y las nuevas tecnologías son hoy instrumentos imprescindibles para el desarrollo humano y para obtener una mejor calidad de vida. Por ello, las nuevas tecnologías, como Internet, suelen ser accesibles a todos los ciudadanos. Dado el interés del tema para las personas con discapacidad traemos a esta sección del Observatorio de la Discapacidad la comunicación de la Unión Europea sobre accesibilidad en los sitios web públicos y de su contenido. Se trata de un documento técnico de gran importancia en el desarrollo de las nuevas tecnologías para las personas con discapacidad. P4:363

La necesidad de que las nuevas tecnologías de la información sean presentadas como un valor de mercado, como una ventaja competitiva, fue el mensaje de José $M^{\mathbf{a}}$ Arroyo, presidente de la ONCE, durante la inauguración del acto por la ministra de Ciencia y Tecnología, Ana Birulés, acompañada por Yannis Vardakastanis, presidente del Foro Europeo de la Discapacidad (EDF) y Vicente Parajón, director general Adjunto de la D.G.S.I. P5:629

OBJETIVOS FAMILIARES La investigación formal en los iMac de Apple es un ejemplo de la intención de convertir el ordenador en un objeto más familiar, lúdico y coloquial, trasladándolo desde el ámbito de los objetos tecnológicos a uno más cercano, el de objeto amigable y con connotaciones afectivas. P6:301

La eliminación de las esquinas, las formas redondeadas, el uso de materiales cálidos, colores vivos y las transparencias son elementos de 
un nuevo lenguaje que configura un "objeto que habla", un nuevo modo de vivir y practicar la tecnología. P6:302

Las nuevas tecnologías informáticas y de comunicación tienen para el colectivo de personas con discapacidad un carácter más de "herramienta" que de ocio. P7:548

Las políticas, las tecnologías, los productos y los servicios deben evitar la discriminación y estar diseñados desde su origen para ser utilizados de manera normalizada por todas las personas en la máxima variedad de circunstancias y situaciones posible. La estrategia del DISEÑO PARA TODOS busca ampliar el concepto de "ciudadano tipo" y abarcar al mayor número de personas posible. P10:394

Un atractivo y simpático contenido multimedia acompaña al visitante del sitio, advirtiéndose enseguida las enormes posibilidades que pueden ofrecer las nuevas tecnologías como herramientas para la integración y comunicación de determinados colectivos, como el de las personas con discapacidad intelectual. P1 1:646

Con la finalidad de hacer de Internet algo cotidiano y cercano a todos los ciudadanos, el Ministerio de Ciencia y Tecnología ha lanzado la iniciativa "Internet para todos", que se plantea como un gran programa de movilización social con el fin de que todos y todas conozcan las ventajas implícitas de estar conectados a la red y, en especial, aquellos sectores de la sociedad, como el de las personas con discapacidad, que han demostrado tener una serie de barreras en el uso de Internet. En este sentidos se ha habilitado una página web, http://www.internetparatodos.es, en donde el visitante dispone de información detallada de esta iniciativa, de los centros de formación, de noticias relacionadas con el proyecto, del temario de los cursos o de otras informaciones útiles para seguir la marcha del programa. P18:438

Estas dos premisas se sumaron a todas las propuestas de futuro enviadas para su análisis a la Cumbre de jefes de Estado de ese mismo mes en la equidad y el respeto a la diversidad cultural", con una repercusión positiva en todos los seres humanos, a los que hay que facilitar el acceso universal a la cultura y al conocimiento, así como el uso de las tecnologías en todas las comunidades para suprimir la brecha nortesur, que sólo conduce a la marginación y la división social. P27:703

...son muchos los que sólo aceptan las aplicaciones técnicas -ya se trate de ayudas especiales o de productos de consumo corriente- con la condición de que tengan un diseño atractivo y se integren bien en 
su entorno normal. Los productos y servicios deben ser atractivos y deben incitar a los interesados a usarlos. P36:729

Tecnología fija, estable y madura. P37:940

Tecnología portátil, cambiante, insegura y emergente. P37:951

\section{CÓDIGOS DE LAS REVISTAS}

Revistas Minusval

\begin{tabular}{|c|c|c|c|}
\hline P1 & $\begin{array}{l}\text { Dossier Proyecto EASTIN. Septiembre - } \\
\text { Octubre } 2005\end{array}$ & P21 & № 148. Noviembre - Diciembre 2004 \\
\hline P2 & Especial Agosto 2005 & $\mathrm{P} 22$ & № 149. Enero - Febrero 2005 \\
\hline P3 & № 130. Septiembre - Octubre 2001 & $\mathrm{P} 23$ & № 150. Marzo - Abril 2005 \\
\hline P4 & № 131. Noviembre - Diciembre 2001 & P24 & № 151. Mayo - Junio 2005 \\
\hline P5 & № 132. Enero - Febrero 2002 & $\mathrm{P} 25$ & № 152. Julio - Agosto 2005 \\
\hline P6 & № 133. Marzo - Abril 2002 & $\mathrm{P} 26$ & № 153. Septiembre - Octubre 2005 \\
\hline P7 & № 134. Mayo - Junio 2002 & $\mathrm{P} 27$ & № 154. Noviembre - Diciembre 2005 \\
\hline P9 & № 136. Septiembre - Octubre 2002 & $\mathrm{P} 28$ & № 155. Enero - Febrero 2006 \\
\hline $\mathrm{P} 10$ & № 137. Noviembre - Diciembre 2002 & P29 & № 156. Marzo - Abril 2006 \\
\hline P11 & № 138. Enero - Febrero 2003 & P30 & № 157. Mayo - Junio 2006 \\
\hline $\mathrm{P} 12$ & № 139. Marzo - Mayo 2003 & P31 & № 158. Julio - Agosto 2006 \\
\hline P13 & № 140. Junio - Julio 2003 & P32 & Especial 25 años del IMSERSO. Diciembre 2003 \\
\hline $\mathrm{P} 14$ & № 141. Agosto - Septiembre 2003 & P33 & Especial La Accesibilidad. Abril 2004 \\
\hline P15 & № 142. Octubre - Diciembre 2003 & P34 & Especial Atención Temprana. Marzo 2003 \\
\hline $\mathrm{P} 16$ & № 143. Enero - Febrero 2004 & P35 & Especial Daño Cerebral. Diciembre 2002 \\
\hline P17 & № 144. Marzo - Abril 2004 & P36 & Especial La Discapacidad en Europa. Mayo 2003 \\
\hline P18 & № 145. Mayo - Junio 2004 & P37 & $\begin{array}{l}\text { Especial Discapacidad y Nuevas Tecnologías. Junio } \\
2002\end{array}$ \\
\hline P19 & № 146. Julio - Agosto 2004 & P38 & № 135. Julio - Agosto 2002 \\
\hline P20 & № 147. Septiembre - Octubre 2004 & & \\
\hline
\end{tabular}




\author{
ANEXO 2 \\ EJEMPLOS REVISTA MINUSVAL \\ IMÁGENES Y VALORES
}

\title{
VALORES RECONOCIDOS
}

\section{A) Positivos}

\section{ACCESIBILIDAD}

"Los gobiernos de Madrid, Cantabria, Andalucía, Galicia y Valencia proporcionan páginas con un alto grado de accesibilidad." P20:505

"El Gálibo es un simulador de una persona en silla de ruedas que facilita la accesibilidad de estas personas a diversos transportes públicos, especialmente taxis y que cuenta con el respaldo de la norma UNE 26494." P18:463

"El equipo mejora la accesibilidad al ordenador, tanto por su condición inalámbrica, como por sus opciones de configuración..." P19:562

"El teclado Bluekey, desarrollado por el Centro de Investigación, Desarrollo y Aplicaciones Tiflotécnicas de la ONCE (CIDAT), permite el acceso de personas con problemas de visión a teléfonos móviles y agendas electrónicas." P23:533

"(...) la Fundación Andaluza de Servicios Sociales, por el interés mostrado en ofrecer a través de su web plenamente accesible (...)" P28:94

"Su información vía web, plenamente accesible, incluye sus Catálogos de Ayudas Técnicas y de Ayudas Artesanales..." P28:724

"AidCat/IBV es una aplicación Web de navegación fácil y respetuosa con las pautas de accesibilidad a Internet." P26:343

\section{ACEPTACIÓN}

... nuevas tecnologías "asequibles, adaptadas, adecuadas, aceptadas y accesibles" P5:662 


\section{ADECUACIÓN}

... nuevas tecnologías "asequibles, adaptadas, adecuadas, aceptadas y accesibles" P5:662

Los resultados del estudio, realizado con pacientes reales, indican que los cojines de aire y de viscoelástico son los más adecuados. P14:155

En el diseño de la vivienda se ha dado especial importancia a la personalización, por lo que se ha optado por los dispositivos más adecuados para la activación de cada función, activación que puede realizarse mediante botones, con la boca, el pie e, incluso, soplando. P26:694

\section{ALIVIO}

El prototipo diseñado por el Instituto de Biomecánica de la Comunidad Valenciana en colaboración con la Dirección General de Integración Social de Discapacitados de la Generalitat Valenciana, único en el mundo, emula la forma tradicional con una parte superior dispuesta para que estribe en ella el codo, y un agarradero en su parte media que alivia las dificultades para caminar. P1 1:713

\section{APOYO}

Vi positiva la ayuda a los demás desde el teléfono dorado; la gente que llama busca compañía telefónica y se la damos. P3:343

El sistema ha sido concebido como una ayuda adicional a la hora de localizar a personas que pueden perderse, ya sea por padecer discapacidades cognitivas como el autismo o por tener problemas de Alzheimer. P16:155

Todas las personas con discapacidad que no puedan valerse por sí mismas recibirán ayudas como teleasistencia... P31:80

Los aparatos compensadores, como los libros de memoria y los sistemas electrónicos de localización (buscas), se utilizan tanto para mejorar funciones cognitivas específicas como para compensar déficits específicos. P35:65

La predicción de palabras, además de acelerar la escritura de las personas con algún tipo de discapacidad motora, también ha demostrado ser de gran ayuda para personas con algún problema de tipo lingüístico, como dislexia, y afasia ligera. P37:866 
Los avances tecnológicos permiten y favorecen estas ayudas, como el DVD o el subtitulado en teletexto, que pueden ayudar a otros colectivos. P38:154

...oferta de servicios móviles orientados a ser la herramienta para superar situaciones concretas de discapacidad. P24:556

Internet cada vez es más valorado por las mujeres con discapacidad como una ayuda para acceder a la información. P10:409

\section{6. $\quad$ AVANCE}

Ana Birulés Ministra de Ciencia y Tecnología "Nadie debe ser excluido de los beneficios y de las ventajas que proporciona el avance tecnológico. P5:645

Este potencial no deja de crecer, a la vista del desarrollo tecnológico del acceso multiplataforma de banda ancha, es decir, la posibilidad de conectarse a Internet a través de medios distintos del PC, tales como la televisión digital y la 3G. Estos avances ofrecen significativas oportunidades económicas y sociales. P38:458

...audífonos tecnológicamente avanzados e implantes cocleares para estimular convenientemente las vías auditivas... P34:1276

Además, poseen extraordinarias condiciones acústicas y están dotados de los medios técnicos y audiovisuales más avanzados, como conexión a Internet en banda ancha en áreas acotadas de asientos del Auditorio 1. P36:214

Importantes avances como las ruedas insonorizadas, ahorro energético y otras en materia de seguridad, se unen a sistemas antiempotramiento, de frenado y ayuda a la conducción, detección y extinción de incendios, así como escaleras semiautomáticas de evacuación. P27:623

"Esta casa representa un avance extraordinario sobre todo para las personas que tienen serias dificultades para realizar actividades de la vida diaria en el hogar. La transformación real de una vivienda normal en una casa accesible para una persona con discapacidades resulta menos cara de lo que en principio pudiera suponerse..." P10:867

\section{BARATO}

La Fundación Vodafone trabaja en una aplicación Java que permite cargar dicho software en multitud de teléfonos y acaba con la dependencia del terminal y el elevado coste que representaba la producción de teléfonos adaptados. P17:168 
El objetivo es aplicar las soluciones tecnológicas de reciente aparición y dotar a las personas sordas de mayor independencia y de mayor calidad de vida a un coste razonable. P15:663

Los rápidos progresos de las tecnologías digitales y el descenso de los precios de los equipos de tecnología de la información han puesto en manos de empresas y consumidores... P38:480

- y más baratas - al poder ser adaptadas a un grupo de usuarios más amplio -. P37:155

...sistemas de interacción independientes de la aplicación y personalizables a relativamente bajo costo... P37:155

\section{BENEFICIO}

La integración de tecnología en el hogar a través de soluciones domóticas aporta múltiples beneficios a las personas con discapacidad... P31:34

El sistema de telemedicina desarrollado por el Hospital Clínico San Carlos de Madrid utiliza la telefonía móvil de $3 G$ para facilitar y mejorar el control postoperatorio domiciliario de los pacientes, por lo que beneficia a las personas afectadas por una grave discapacidad, que no tendrán que desplazarse al hospital. P20:504

Se pueden beneficiar pacientes con esclerosis múltiple, Parkinson y aquellas personas que consumen medicamentos que interfieren con actividades motoras susceptibles de agravar el temblor fisiológico natural. P23:692

Uno de los principales beneficios que el hogar inteligente aporta a las personas cuyas discapacidades limitan sus posibilidades de desplazamiento es el teletrabajo. P 15:812

"Pese a que los avances en accesibilidad parezcan más útiles para las personas con necesidades especiales, es toda la sociedad la que se beneficia de los mismos", afirmó Alfonso Berlanga. P27:692

...niños con Síndrome de Down, por ejemplo, se están beneficiando del uso de ordenador... P37:86

\section{BIENESTAR}

En general, existe un gran desconocimiento de las prestaciones domóticas, de sus posibles aplicaciones y de sus posibilidades para 
conseguir un aumento del bienestar, lo que se ha empezado a llamar "Domótica Asistencial". P3 1:193

Obteniendo un notable ahorro de energía, una eficaz gestión técnica de la vivienda, una buena comunicación. Se habla de la "casa del futuro", del "Hogar Digital", como una posible solución que facilitará las condiciones de vida del mayor, de la persona dependiente o con alguna discapacidad en su propio domicilio, así como la mejora de su bienestar e independencia, facilitando una mayor comunicación con el exterior, la familia, los médicos o con un servicio de teleasistencia. P31:176

\section{CALIDAD}

Este nuevo Servicio, como Vd. sabe, ha merecido el Premio lbest 2001 a la calidad. P3:20

Motivados, en muchos casos, por la necesidad de dar solución a las necesidades concretas de algún amigo o familiar, diseñaron adaptaciones "artesanales" de sorprendente calidad y utilidad. P37:152

El premio Sidar es un prestigioso galardón que se lleva concediendo desde hace tres años a los sitios WEB que se caracterizan por tener un diseño de calidad... P10:97

El crisol de páginas y sitios web que aportan información sobre discapacidad no sólo se encuentra en constante crecimiento y transformación, sino que los niveles de servicio y calidad ofrecidos son cada vez mayores. P4:335

\section{CALIDAD DE VIDA}

Francisco Limonche, vicedecano del colegio oficial de ingenieros técnicos de telecomunicación, explicó que de lo se trataba en un hogar digital es que reinasen los criterios de comunicación, seguridad, calidad de vida y ahorro de energía. P27:138

Estas plataformas constituyen un instrumento de accesibilidad que permite evitar, compensar, mitigar o neutralizar las limitaciones funcionales, contribuyendo a una mayor autonomía personal y calidad de vida al facilitar el acceso a dispositivos domésticos y a recursos asistenciales externos. P31:322

Los Hogares Digitales son considerados como herramientas de accesibilidad, que contribuyen a la mejora de la autonomía personal y la calidad de vida, facilitando el acceso a los dispositivos domésticos y a los recursos externos. P31:249 
La sociedad de la información y las nuevas tecnologías son hoy instrumentos imprescindibles para el desarrollo humano y para obtener una mejor calidad de vida. P4:363

...una consecuencia de estas relativamente elevadas tasas de penetración del ordenador, es su consideración de ayuda técnica necesaria y eficaz para la mejora de la calidad de vida de estas personas y, por lo tanto, potencialmente financiable. P9:190

La generalización de la utilización de los ordenadores en el terreno laboral y doméstico, la contribución de estos equipos a la mejora de la calidad de vida... P17:159

La utilización de nuevas tecnologías y sistemas de domótica en la atención a personas con Alzheimer y sus familias, incidiendo en la mejora de la calidad de vida y autonomía por parte de los usuarios y un mejor servicio integral de atención y apoyo individualizado. P22:301

\section{CAMBIO}

El cambio más espectacular lo ha aportado el World Wide Web. La tecnología web se apoya en varios protocolos susceptibles de ser modificados y ampliados para mejorar la accesibilidad y utiliza varios tipos de programas que tienen problemas específicos para ciertas discapacidades. P37:1239

... la inclusión del ordenador dentro del proceso de evaluación neuropsicológica ha supuesto un cambio significativo para la obtención de información sobre el estado funcional del paciente y para el propio proceso de evaluación... P35:592

Esto era un sueño que ya hace diez años había intentado realizar la Comisión Europea con el proyecto Handynet, pero entonces no podía contar con la gran novedad - naturalmente hablamos de Internet - que ha revolucionado el mundo de la información en los años sucesivos. P1:06

El formador no sólo cumple una función de carácter pedagógico, informando, orientando y resolviendo dudas, sino que también pretende despertar el interés del alumno, mostrándole cómo Internet puede cambiar su vida. P9:283

\section{CERCANÍA}

El desarrollo de una nueva telemedicina más cercana al ciudadano y más práctica donde las personas de más alto riesgo (crónicos, postoperados), y los que precisan supervisión continua como las embarazadas, sean 
monitorizadas a distancia con procedimientos prácticamente autónomos, independizando o eliminando la simultaneidad paciente-enfermo, es una de las soluciones de la telefonía móvil... P5:615

\section{COMODIDAD}

...ha incrementado la demanda de ayudas técnicas que permitan a estos colectivos la utilización de los dispositivos informáticos con el mayor grado de comodidad y efectividad posible. P17:159

..."hogar inteligente", un lugar donde el confort, el ahorro de tiempo y la interacción desde cualquier lugar entre el ser humano y los aparatos que le rodean son los protagonistas. P15:776

SpringBoard es flexible, fácil de personalizar, y cómodo de llevar. P24:642

El sistema es compatible con distintos tamaños y modelos de sillas de ruedas, su diseño es ergonómico, fácil de uso, de sencillo almacenaje y mínimo mantenimiento, muy cómodo para el profesional y para el paciente. P13:624

\section{COMUNICACIÓN}

Nuestro terminal permite la comunicación en modo texto con muchos otros equipos estándar, lo que amplía considerablemente las posibilidades de comunicación... P6:254

Por otra parte, está Internet que ha aumentado las posibilidades de comunicación para personas ciegas y sordas o con capacidad motora reducida. P16:151

El correo-e es una herramienta de comunicación vía Internet, con innumerables ventajas frente al teléfono o al fax, configurándose como el medio más eficaz y rápido de comunicación que permite intercambiar, además de mensajes, programas, audio, video e imágenes. P4:351

La radio y el sitio web, canales de comunicación interactivos se han transformado en un espacio comunitario que contribuye notablemente a que las personas rehabiliten habilidades sociales y cognitivas y les ha dado la oportunidad de hablar y ser escuchados. P4:643

MexVox mejora la comunicación de las personas ciegas MexVox permite a las personas ciegas o con deficiencias visuales mejorar su comunicación a través de la utilización de un sistema de síntesis de voz. P2 1:902 


\section{CONFIANZA}

El neuropsicólogo experto debe observar los datos y la ejecución de las tareas que los pacientes realizan y de ellos inferir un juicio clínico; el ordenador facilita ésta tarea y la hace más confiable. P35:653

El uso de ordenadores para la evaluación neuropsicológica en ningún caso sustituye al neuropsicólogo pero es fundamental para su labor, aportando precisión en la recogida de datos y una mayor fiabilidad. P35:652

\section{EFECTIVIDAD}

La generalización de la utilización de los ordenadores en el terreno laboral y doméstico, la contribución de estos equipos a la mejora de la calidad de vida y la introducción de Internet en todos los ámbitos de la vida cotidiana ha incrementado la demanda de ayudas técnicas que permitan a estos colectivos la utilización de los dispositivos informáticos con el mayor grado de comodidad y efectividad posible. P17:159

\section{EFICACIA}

El sistema también mejora el control postoperatorio, aumentado la eficacia del mismo... P20:504

En el ámbito concreto de la comunicación se hacía preciso conocer el "estado del arte" de aquellas tecnologías, productos y servicios que, directa $o$ indirectamente relacionados con las telecomunicaciones, intervienen o se estiman necesarios para un desenvolvimiento eficaz y equilibrado de la vida de las personas con discapacidad y mayores. P5:324

Como señala infomedula.org, los equipos cuentan con ratones controlados por movimientos de cabeza, especialmente eficaces para personas con lesiones medulares altas y de tipo cerebrovascular. P22:558

CRECER cuenta con un sistema computarizado propio y único de entrenamiento del equilibrio, representa hoy en día, uno de los sistemas más eficaces en la recuperación de los pacientes neurológicos. P35:722

En las Administraciones Públicas está implantado el uso del ordenador, eficaz para personas con discapacidad. P7I:629

Los colectivos con mayor presencia de ordenador en las personas con discapacidad física, visual y auditiva; una consecuencia de estas relativamente elevadas tasas de penetración del ordenador, es su consideración de ayuda técnica necesaria y eficaz para la mejora de la 
calidad de vida de estas personas $y$, por lo tanto, potencialmente financiable. P9:190

El sistema Braille supone, para estas personas, el medio más eficaz e independiente para acceder a la información $y$, sobre todo, a la educación. P37:787

\section{EFICIENCIA}

Por "domótica" se entiende la incorporación al equipamiento de las viviendas y edificios de elementos tecnológicos que permiten gestionar de forma eficiente, segura y confortable para el usuario, los distintos aparatos e instalaciones domésticas tradicionales que conforman una vivienda... P31:34

Como se puede ver a lo largo de lo expuesto, hemos diseñado un hardware alternativo a los existentes, basado en un microcontrolador, de manera que resulta portable y eficiente, además de económico. P37:760

\section{ESPERANZA}

Por otro lado, la difusión y uso intensivo de las nuevas tecnologías de la información abre muchas posibilidades para el fomento de la participación social y la lucha contra la exclusión... P32:753

Por ello, resulta obligada una colaboración entre la neuropsicología y los especialistas en el desarrollo de sistemas informáticos y ayudas técnicas para personas con discapacidad. Así, junto a los ya existentes sistemas aumentativos de comunicación o programas de rehabilitación cognitiva con soporte informático se está empezando a desarrollar toda una gama de dispositivos tecnológicos que amplía de forma muy notable las posibilidades de intervención. P35:968

Según la economía global se hace más interdependiente y las barreras culturales y de la comunicación entre personas con discapacidad en varios países son eliminadas por el uso creciente de Internet, los beneficios potenciales de la cooperación y la coordinación entre los distribuidores de información sobre tecnología de apoyo parecen ser numerosos y alcanzables. P1:25

Las nuevas tecnologías están generando enormes expectativas... P5:639

Internet ofrece enormes posibilidades para determinados colectivos, como las personas con discapacidad o las mayores... P9:173

Se habla de la "casa del futuro", del "Hogar Digital", como una posible solución que facilitará las condiciones de vida del mayor, de la persona 
dependiente o con alguna discapacidad en su propio domicilio, así como la mejora de su bienestar e independencia, facilitando una mayor comunicación con el exterior, la familia, los médicos o con un servicio de teleasistencia. P31:187

\section{EQUILIBRIO}

En el ámbito concreto de la comunicación se hacía preciso conocer el "estado del arte" de aquellas tecnologías, productos y servicios que, directa $o$ indirectamente relacionados con las telecomunicaciones, intervienen o se estiman necesarios para un desenvolvimiento eficaz y equilibrado de la vida de las personas con discapacidad y mayores. P5:324

\section{FACILITAR}

Pero, entre todos estos objetivos, subyace la idea de que Internet es la herramienta ideal para facilitar y agilizar la comunicación entre asociados, médicos y personas interesadas por la enfermedad de Parkinson. P22:468

...una silla de ruedas de materiales ligeros evita sobreesfuerzos al usuario... P14:161

Integra la funcionalidad completa de un teléfono móvil junto con muchas de las facilidades que brinda un ordenador personal... P6:245

El sistema consiste en la incorporación en el terminal de la aplicación Mobile Accessibility, basada en la integración de un sintetizador de voz, que facilita el acceso a las funciones $\sin$ necesidad de dispositivos externos. P17:171

La Fundación AUNA considera que el ordenador es uno de los equipos que favorece en mayor medida la atención educativa de los niños con plurideficiencias, ya que facilita su estimulación sensorial... P25:693

El neuropsicólogo experto debe observar los datos y la ejecución de las tareas que los pacientes realizan y de ellos inferir un juicio clínico; el ordenador facilita ésta tarea y la hace más confiable. P35:653

...se han diseñado grúas y sillas que facilitan la movilidad en el hogar... P14:157

"iPronto" es el mando universal concebido por "Philips" para facilitar la gestión central del domicilio desde cualquier dependencia. El aparato está equipado con un panel táctil que permite controlar la iluminación, las cámaras de seguridad y la climatización. P15:817 
Mensavoz es el nuevo servicio de Amena, diseñado para facilitar la recepción de SMS a las personas con discapacidades visuales. P18:490

El teclado ha sido diseñado para facilitar la escritura y la pantalla a color y de generosas dimensiones ofrece mejor visibilidad. P19:568

...ayudas técnicas, herramientas y software de libre disposición para facilitar el acceso a Internet y el uso de ordenadores personales por parte de personas mayores y con discapacidad. P30:431

\section{FAVORECER}

Los avances tecnológicos permiten y favorecen estas ayudas, como el DVD o el subtitulado en teletexto, que pueden ayudar a otros colectivos. P38:154

...favorecen el acceso a medios audiovisuales y a una extensa gama de servicios de ocio para el usuario y familia desde cualquier televisor... P30:583

\section{FIABILIDAD}

La batería cuenta con una aceptable validez y fiabilidad, así como con abundantes datos normativos. P35:586

\section{IGUALDAD}

Un 48\% de los más de tres millones y medio de personas con discapacidad que existen en España utiliza Internet y un elevado porcentaje lo constituyen las personas con problemas de audición, que han encontrado en este medio una alternativa a la comunicación tradicional por voz, que les permite intercambiar impresiones al mismo nivel que lo hace cualquier otro usuario de la red. P19:544

Como alternativa a los métodos tradicionales de búsqueda de información o servicios, como puede ser el acudir a una biblioteca o a un hipermercado, cualquier persona puede hacer uso de Internet y buscar la información deseada o realizar sus compras. P9:198

...las posibilidades técnicas, económicas y sociales de las nuevas tecnologías en su doble vertiente,...como medio para lograr la independencia y autonomía de las personas con discapacidad, y como herramienta dirigida a favorecer la inclusión en todos los ámbitos, educativo, laboral, cultural y de ocio, en igualdad de condiciones que el resto de la sociedad. P5:628 
...pensando que las Nuevas Tecnologías son el elemento fundamental para reducir la diferencia y lograr la equiparación de oportunidades. P3:475

\section{IMPORTANCIA}

Atendiendo a la importancia de estas tecnologías, los ministerios de Trabajo y Asuntos Sociales, a través del IMSERSO, y de Ciencia y Tecnología, junto con el Comité Español de Representantes de Minusválidos (CERMI) han promovido la elaboración del Libro Blanco de $I+D+I$ al servicio de las personas con discapacidad y de las personas mayores. P12:222

Debemos considerar esta web como un importante recurso de promoción y consulta de la campaña promovida por la Comisión Europea. P13:562

\section{INDEPENDENCIA}

Desde el punto de vista del apoyo a la vida independiente se puede decir que, genéricamente, estas plataformas integran cuatro tipos de servicios... P31:322

En el campo de la domótica, la empresa B \& J Adaptaciones presentó un conjunto de ayudas técnicas que aumentan la autonomía del discapacitado en su vivienda. P14:156

Asimismo, el desarrollo científico y tecnológico introduce avances en la accesibilidad con aumento de la autonomía en la movilidad y con sistemas de control de entorno. P7:571

Yo estoy convencido que las nuevas tecnologías ayudan a las personas a ser independientes. P1 1:891

Las ayudas ambulatorias como son los andadores y bastones pueden usarse temporalmente mientras el niño está progresando o como ayudas a largo plazo para dar al niño una independencia en su movilidad. $\mathrm{P} 29: 235$

V Congreso Internacional de Domótica, Robótica y Teleasistencia Nuevas tecnologías que hacen la vida más independiente. P27:699

La Comunidad Valenciana presentó el proyecto de facilitar a las personas con discapacidad muletas anfibias, prototipo que completa junto con las sillas anfibias, el Plan de Playas Accesibles dentro de esta comuna de 700 unidades, "va a facilitar que una persona con discapacidad pueda ser más independiente y autónoma si quiero dame un baño en el mar". P11:702 
Queremos hacer posible que las personas que no pueden valerse por sí mismas perciban una serie de servicios (ayuda a domicilio, teleasistencia, ayudas técnicas, plazas residenciales,...) que potencien su autonomía y posibiliten el acceso al mercado laboral de sus cuidadores familiares. P2:21

...las telecomunicaciones juegan un papel importante en la reducción del aislamiento y la soledad, en la evitación de la ansiedad y de la fatiga, en el incremento de la independencia, la reducción de la dependencia, y ofrecen oportunidades de formación y empleo. P10:401

\section{INNOVACIÓN}

Proyectos como WAI (Accesibilidad a la red), INCLUDE (Inclusión de Personas con Discapacidad y Mayores en la Telemática), y la acción COST 219 "Telecomunicaciones para Todos" han proporcionado nuevos datos y enfoques innovadores. P6:179

Importante galardón para "IRDATA" Infrarrojo y Microelectrónica, S.L. (IRDATA), fabricante de dispositivos de acceso al ordenador para personas con discapacidad, ha sido distinguida recientemente con la mención honorífica del Premio de Innovación Tecnológica de la Comunidad de Madrid. P5:577

\section{INTEGRACIÓN}

... fomentar el uso de las Tecnologías de la Información y la Comunicación (TIC) y el Software Libre como herramienta para informar y facilitar la integración de las personas con discapacidad. P30:429

Este programa nació en 1999, en colaboración con la Fundación Síndrome de Down de Madrid y la Universidad Carlos III, con objeto de crear una metodología capaz de formar a personas con Síndrome de Down y otras necesidades educativas especiales en la utilización del ordenador y las TIC a fin de favorecer su integración social, educativa y laboral. P21:894

Para las personas ciegas, los sistemas "hápticos" como GRAB, los combinados con sonidos, los futuros "plug ins" para páginas web y otros medios suponen un gran avance para la integración de este grupo en la sociedad de la información, señaló Enrique Várela, director de tecnología accesible de la fundación ONCE. P27:131

...los avances registrados por las nuevas tecnologías y la disponibilidad en Internet de los negocios tradicionales, han contribuido a la integración de personas con discapacidad... P22:778 
En un primer avance de conclusiones es preciso asumir que las nuevas tecnologías son un medio de integración social, y un mecanismo de integración sociolaboral y que constituyen una tecnología beligerante para disminuir diferencias. P5:639

Xabi Madina pone la informática en manos de las personas con graves dificultades motoras, "hay que tener en cuenta que cualquier persona minusválida que se quede fuera de la informática se está poniendo ella misma otra barrera: si no sabe utilizar un ordenador o navegar por Internet se va quedar fuera del mundo. En este sentido la informática es integradora, aunque no tengamos movilidad podemos movernos". P1 1:897

Desde hace tiempo las páginas de Minusval vienen poniendo de relieve la importancia de las Tecnologías de la Información y la Comunicación (TIC) como herramientas indispensables para la integración social y laboral de las personas con discapacidad. P9:54

\section{INTELIGENCIA}

Concha Mayoral explica a Antonio Lis el funcionamiento del sistema de control informatizado de la "casa inteligente" ubicada en el CRMF. P10:874

...el diseño de una "tarjeta inteligente", capaz de abrir puertas sin necesidad de ponerla en contacto con un lector, ya que actúa a distancia. P6:62

\section{INTERESANTE}

Esta aplicación se constituye como una solución económica y sencilla especialmente interesante para aquellas personas que, bien por problemas de discapacidad o por su avanzada edad, tengan problemas para desplazarse... P22:779

Internet me ha parecido muy interesante porque puedes encontrar muchas cosas (trabajo, noticias, amigos...)... P9:452

\section{LÚDICO}

La investigación formal en los iMac de Apple es un ejemplo de la intención de convertir el ordenador en un objeto más familiar, lúdico y coloquial... P6:301 


\section{MEJORA}

En materia de comunicaciones, el hogar digital realiza dos aportaciones notables a las personas con discapacidad. P15:796

Esta generalización de las mejoras de accesibilidad ha favorecido la percepción, por parte de los usuarios, de que la plataforma baja ha contribuido mucho a la mejora en la calidad del servicio. P28:334

...las órtesis (dispositivos que compensan y mejoran una funcionalidad presente pero debilitada, como un bitutor para pierna, un par de gafas, un audífono)... P1:3

Se pueden prevenir con la utilización de férulas, órtesis, aparatos que mejoran la alineación de las extremidades... P29:225

La Conferencia de Biología Experimental de San Francisco ha acogido la presentación de un ojo y un brazo biónicos, que mejoran procesos fisiológicos y estructuras anatómicas reproduciendo la función original mediante la utilización de componentes mecánicos y electrónicos. P30:757

Los marcadores de idioma mejoran la legibilidad de la Web para todo el mundo, incluso para aquéllos con discapacidades de aprendizaje, cognitivas o auditivas. P37:1069

Las mejoras tecnológicas, que se van sucediendo de forma constante, alcanzan también a las paradas, donde se comienzan a ofrecer sistemas de indicación de tiempo de espera, por paneles electrónicos o mensajes telefónicos, apoyos isquiáticos y otras soluciones. P28:343

\section{MODERNO}

Las modernas técnicas de neuroimagen funcional (tomografía de emisión de positrones, resonancia magnética funcional, magnetoencefalografía...) permiten captar en tiempo real imágenes de los cambios fisiológicos... P35:960

... un sistema GSM o Bluetooth al ser una tecnología muy novedosa para todos. P37:927

El bastón para invidentes Zingbee auna las tecnologías más novedosas con las etiquetas electrónicas de radiofrecuencia instaladas en lugares públicos. P26:718

El desarrollo de estas novedosas técnicas (estimulación magnética transcraneal, tomografía de emisión de positrones o RMN funcional), nos 
demuestra mediante mapeos sistemáticos, que el cerebro, aún en un adulto con daño cerebral sobrevenido, posee una plasticidad mayor de lo que se pensaba. P35:865

\section{NATURAL}

...la adaptación protésica y la intervención logopédica más adecuada, con objeto de que el niño con discapacidad auditiva pueda desarrollar con mayor facilidad y de manera más natural todas sus capacidades y habilidades cognitivas... P34:1294

Nacen nuevas tipologías de objetos que ya no tienen nada en común con los utensilios mecánicos y las prótesis motrices y sensoriales a las que estábamos acostumbrados. Se parecen cada vez más a los organismos vivientes... P6:309

\section{NECESARIO}

Los servicios a través de la web son cada vez más necesarios para la vida diaria de los ciudadanos... P6:439

La dismetría ocasionada pude compensarla con un zapato de tacón, normal, de unos $7 \mathrm{cms}$ del que no puedo prescindir. P7:635

Internet es una de ellas y en la actualidad se considera una tecnología esencial en ámbitos tales como la comunicación, la información y la prestación de servicios. P9:167

El ordenador se ha convertido en una herramienta imprescindible en el entorno profesional, donde ha contribuido a facilitar el acceso de las personas con discapacidad al mercado laboral tanto de forma presencial como remota. P26:698

Para los niños pre-adolescentes y adolescentes se hace indispensable el uso de las sillas de ruedas, ya sea para que se puedan desplazar en la comunidad o para actividades recreativas. P29:238

...elevadas tasas de penetración del ordenador, es su consideración de ayuda técnica necesaria... P9:190

Actualmente necesito una silla de ruedas para poder desplazarme... P29:325

Al convertirse las redes y los ordenadores en parte esencial de la vida cotidiana y empresarial... P38:506 


\section{OPORTUNIDAD}

Internet ofrece cada vez mayores posibilidades como guía para el futuro de los discapacitados. P19:662

...aprovechando las oportunidades que nos ofrecen las nuevas tecnologías... P3:225

...la extensión del uso de las nuevas tecnologías como herramienta básica que permite al discapacitado desarrollar diversas actividades profesionales y de formación principalmente sin necesidad de desplazamientos. P4:493

...permitiéndoles participar de todas las posibilidades que ofrecen las tecnologías digitales. P4:364

El objetivo de EASTIN es crear este recurso utilizando las posibilidades que ofrece Internet. P23:523

...las telecomunicaciones (...) ofrecen oportunidades de formación y empleo. P10:401

\section{POTENCIA}

Los rápidos progresos de las tecnologías digitales y el descenso de los precios de los equipos de tecnología de la información han puesto en manos de empresas y consumidores unos dispositivos más potentes. P38:480

Internet, y más en concreto la World Wide Web es probablemente la herramienta más potente de comunicación y difusión de información que podamos encontrar en la actualidad. P9:326

\section{POSITIVO}

...entre las facetas de la vida cotidiana de las personas con discapacidad y mayores consultadas y sobre las cuales se estima pueda tener influencia el uso del móvil, siempre se encuentra que éste ejerce un efecto positivo... P5:337

Adaptaciones simples y flexibles permiten que el mismo producto o servicio sea utilizado por mayor número de personas $y$, al mismo tiempo resulten positivas para el resto de los usuarios. P6:399 


\section{PRECISIÓN}

El uso de ordenadores para la evaluación neuropsicológica en ningún caso sustituye al neuropsicólogo pero es fundamental para su labor, aportando precisión en la recogida de datos... P35:652

En concreto, la aplicación NED/IBV SGE permite valorar los rangos de movimiento de las articulaciones de los dedos de la mano, la muñeca, el codo, los dedos de los pies, el tobillo, la rodilla y la cadera, de forma rápida, precisa y repetible. P17:187

\section{RAPIDEZ}

Internet, y más en concreto la World Wide Web es probablemente la herramienta más potente de comunicación y difusión de información que podamos encontrar en la actualidad. Su carácter universal, su inmediatez... P9:326

El correo-e es una herramienta de comunicación vía Internet, con innumerables ventajas frente al teléfono o al fax, configurándose como el medio más eficaz y rápido de comunicación... P4:351

\section{RESPETO}

AidCat/IBV es una aplicación Web de navegación fácil y respetuosa con las pautas de accesibilidad a Internet. P1:168

\section{SEGURIDAD}

El prototipo (...) permite un desarrollo seguro por la arena y el acceso al mar. P1 1:713

...el teléfono móvil es una herramienta concebida por los usuarios, al menos inicialmente, como factor o canal de seguridad... P5:333

El sistema [DE TELEMEDICINA] también mejora el control postoperatorio, aumentado la eficacia del mismo e incrementando la sensación de seguridad de los pacientes. P20:504

Dispositivos para localizar a una persona que se ha extraviado o se ha ausentado de su lugar de residencia, elementos para proteger las aberturas al exterior, mecanismos para detectar fugas de gas o pérdidas de agua, sistemas de seguridad para evitar accidentes con aparatos eléctricos y electrodomésticos en general, permiten reducir riesgos manteniendo, en lo posible, la autonomía de la persona. P33:724 
El servicio de teleasistencia se articula a través de componentes tecnológicos y personales, que proporcionan a los usuarios la seguridad de una respuesta inmediata ante cualquier emergencia y previene eficazmente las sensaciones de inseguridad, soledad y aislamiento. P2:241

Las telecomunicaciones también son de vital importancia para ofrecer seguridad y servir en las emergencias. P10:401

\section{SENCILLEZ}

Una web sencilla, sólo salpicada por iconos de fácil interpretación y que huye de recursos gráficos complejos, tiene como novedad la posibilidad de aplicar al sitio audio, con el fin de facilitar su uso a aquellas personas que lo visiten con dificultades en la visión. P13:560

Se puede personalizar las características de la pantalla: tipo y tamaño de la letra, video inverso, etc. De forma que sea fácil de uso para un gran número de personas, incluso las que padezcan algún tipo de discapacidad visual. P6:249

El sistema es compatible con distintos tamaños y modelos de sillas de ruedas, su diseño es ergonómico, fácil de uso, de sencillo almacenaje y mínimo mantenimiento... P13:624

...está equipado con diez ordenadores conectados a la red, y cuenta con software y las adaptaciones necesarias para que estas personas puedan utilizarlos con facilidad. P27:670

La interfaz física es bastante sencilla (display integrado con otros dispositivos estándares de la silla)... P37:695

El teclado Bluekey, desarrollado por el Centro de Investigación, Desarrollo y Aplicaciones Tiflotécnicas de la ONCE (CIDAT), permite el acceso de personas con problemas de visión a teléfonos móviles y agendas electrónicas. El dispositivo, que se caracteriza por su sencillez de uso, está equipado con ocho puntos, teclas de control y joystick y utiliza el sistema braille. P23:533

...páginas web accesibles para discapacitados visuales que a su vez son de uso más fácil para las demás personas... P4:489

45. SOLUCIÓN

... existen dispositivos de mejora que solucionan los problemas habituales... PI7:162 
...el acceso a las nuevas tecnologías y, en especial, a la informática y a Internet, ha impulsado el desarrollo de soluciones que resuelven las carencias que padece este colectivo... P20:495

Se han desarrollado soluciones mecánicas para adaptar los teclados a los usuarios con necesidades especiales, como el licornio, coberturas especiales para las teclas, etc. P37:555

...una nueva vía de investigación al tiempo que aporta soluciones prácticas para la movilidad y autonomía de las personas con Parkinson. $\mathrm{P} 22: 311$

\section{TRANQUILIDAD}

Efectos del teléfono móvil sobre aspectos cotidianos. (...) tranquilidad... P5:349

47. ÚTIL

El nuevo teclado se conecta al puerto USB del PC, pudiendo funcionar a la vez que el teclado ordinario y facilitando cualquier tarea a las personas invidentes, siendo de especial utilidad a aquéllas con problemas motores que escribirán con mayor agilidad. P30:756

Como ventajas añadidas, Tormes asiste al invidente en rutas de nueva creación o elegidas con anterioridad; permite grabar y reproducir el camino recorrido, elemento de especial utilidad en actividades deportivas o en paseos por grandes espacios, hasta ahora, muy problemáticos para este colectivo... P16:170

Doctor MMS permite el diagnóstico remoto de pacientes que se encuentran en su domicilio mediante la combinación de la telefonía móvil, la fotografía digital e Internet, por lo que resulta de especial utilidad para personas con movilidad reducida. P31:530

Las nuevas tecnologías, y en especial la informática, resultan de gran utilidad para personas que padecen problemas cognitivos 0 de comunicación... P20:500

Promovido por la Asociación para la promoción social y cultural de disminuidos físicos (AUXILIA-Lugo), esta web se presenta como una herramienta de gran utilidad a la hora de planificar ocio y compras tanto para los ciudadanos lucenses con discapacidad como a todos aquellos que visiten la ciudad, con el valor añadido de que son las propias personas con discapacidad las encargadas de supervisar la recopilación de datos. P28:381 
Entre las ventajas que presenta el uso de las pruebas computerizadas destacan la capacidad del ordenador de seleccionar y almacenar un gran número de estímulos, por lo que se pueden diseñar pruebas para medir múltiples variables al mismo tiempo, aspecto muy útil para la evaluación desde los enfoques cuantitativo y cualitativo, permitiendo realizar un análisis de las variables recogidas mucho más preciso, específico y detallado. P35:593

Los teclados virtuales resultan de utilidad a aquellas personas que padecen algún tipo de discapacidad física que limita sus movimientos, impidiéndoles la utilización del teclado físico estándar. P26:699

El "Secuenciador ASR" tiene una utilidad clara para todos aquellos profesionales que deseen utilizar metodología observacional en su trabajo con personas con discapacidad. P12:143

\section{VALIDEZ}

\section{LA BATERÍA CUENTA CON UNA ACEPTABLE VALIDEZ... P35:586}

49. VARIEDAD

...esta interesante web que amplia la oferta existente en Internet sobre recursos especializados en la adecuación del entorno... P24:530

\section{VENTAJA}

...las enormes ventajas de nuevas tecnologías. P26:317

Los web services tienen la ventaja de que son completamente independientes de la plataforma... P26:359

Ana Birulés Ministra de Ciencia y Tecnología "Nadie debe ser excluido de los beneficios y de las ventajas que proporciona el avance tecnológico." P5:645

La revolución de la tecnología de la información aporta muchas ventajas... P6:393

...las ventajas implícitas de estar conectados a la red... P18:438

Según informa Entre Bits, el adaptador presenta, entre sus ventajas, la posibilidad de ajuste según el grado de temblor de la mano, y la de una posible configuración que filtre los "clicks" involuntarios. P23:692 
La telefonía fija y sobre todo el móvil, fueron puntos estrellas de las exposiciones, sin obviar las ventajas de aplicar la tecnología en el hogar para lograr llevar una vida autónoma en la medida de lo posible. P3 1:49

Entre las ventajas que presenta el uso de las pruebas computerizadas destacan... P35:593

Las personas con discapacidad han conocido las ventajas de las nuevas tecnologías y en muchos casos se han adelantado al resto de la población... P37:77

...niños con dificultades motrices y de comunicación están aprovechando las ventajas de la informática para aumentar sus interacciones y su aprendizaje... P37:86

\section{VERSATILIDAD}

Este objetivo no constituye ni mucho menos una utopía, sino que es perfectamente alcanzable gracias a la enorme versatilidad que las tecnologías de la sociedad de la información ofrecen hoy en día. P31:325

Por suerte, el ordenador es la máquina más fácilmente modificable y adaptable a las necesidades del usuario, cualidad que ha logrado convertir al ordenador en un elemento valioso para las personas con discapacidad, que no encontrarán en otras máquinas tanta facilidad para la adaptación. P37:1264

Por último, cabe indicar que funciones de seguimiento de los progresos de los usuarios y sistemas tutores y de ayuda al aprendizaje son fácilmente adaptables al sistema de navegación de una silla de ruedas eléctrica sin muchas dificultades en su ejecución. P37:688

SpringBoard es flexible, fácil de personalizar, y cómodo de llevar. P24:642

Los teléfonos GPS se adaptan a las necesidades de los invidentes. P25:705

\section{B) Negativos}

1. BRECHA

...estos colectivos sufrirán la discriminación en la llamada "brecha digital"... P14:169 
La jornada pretende acercar la Red a aquellos colectivos más desconectados con la Sociedad de la Información, como el de personas con discapacidad, fomentando su participación y el compromiso social para concienciar de sus ventajas y reducir en lo posible lo que viene denominándose como "brecha digital". P 25:410

El curso, que se celebra entre el 19 de octubre de 2005 y el 19 de mayo de 2006, ofrece una formación especializada en el desarrollo de tecnologías accesibles a las personas con discapacidad, partiendo de que el desconocimiento existente a nivel formativo en este campo provoca el diseño de servicios que incrementan la "brecha digital". P26:71 1

Esta idea de la no exclusión de las personas con discapacidad y mayores en el acceso a la sociedad de la información fue reiterada durante el congreso, alegándose que la inaccesibilidad de las nuevas tecnologías puede crear una "brecha digital". P14:163

Por otro lado, la difusión y uso intensivo de las nuevas tecnologías de la información abre muchas posibilidades para el fomento de la participación social y la lucha contra la exclusión, que habrá de superar los riesgos de la brecha digital. P32:753

El acceso a las nuevas tecnologías está ralentizado en el caso de mujeres con discapacidad... P10:401

\section{CARO}

... conocer el alto precio de las prótesis y la falta de financiación por parte de las comunidades autónomas... P25:622

Sin duda, el elemento más caro es la cámara... P37:760

Razones por las que no está satisfecho con los servicios que tiene contratados para el teléfono convencional (...) Caros... P5:351

En algunos casos por desconocimiento (Centro de Intermediación), en otros insuficientemente provistos aunque con gran demanda (Teleasistencia) o caros y con pocas prestaciones en la actualidad (Teléfono de Textos.) P7:559

De este modo, las interfaces utilizadas en las sillas de ruedas autónomas frecuentemente son o bien dispositivos sofisticados y caros, tales como ordenadores portátiles, claramente infrautilizados... P37:663

...el material deportivo: sillas de ruedas, prótesis tienen un coste elevado por su composición y sofisticación. P38:304 
La telefonía de textos ha tenido un gran inconveniente desde su aparición: su elevado coste, ya que a igualdad de información transmitida, se tarda mucho más en hacerlo de forma escrita que hablada. Y hasta ahora todos los sistemas de telefonía, fija o móvil GSM, han tarificado por tiempo de conexión. P6:258

El aumento de la plantilla de eurotaxis, ya que sabemos que es un tema muy complicado porque es un vehículo muy caro, aunque con subvenciones, pero pienso que son pocas y que las subvenciones de este tipo de vehículos debería ser mayor, incluso hasta el seguro del vehículo en sí. P14:482

\section{COMPLEJIDAD}

Cambios sencillos como el de un grifo tradicional por un monomando puede representar una dificultad para adaptarse a un nuevo modo de utilizar el dispositivo y cambios más complejos que requieran de mandos a distancia, manipulación de aparatos electrónicos o similares no son asimilados con facilidad. P33:721

\section{DEPENDENCIA}

Independientemente de nuestra edad y habilidades técnicas y sensoriales, nuestra dependencia de los servicios o productos tecnológicos en la vida diaria es creciente. P6:393

Excesiva dependencia del vehículo particular y de acompañantes en las personas con discapacidad. P7:553

Los que tenemos una discapacidad por sufrir un accidente, en lo primero que pensamos es en la cantidad de cosas que ya no vamos a poder hacer. Con esta falta de libertad que sientes por estar en una silla de ruedas... P5:711

\section{DESIGUALDAD}

La eliminación de barreras arquitectónicas ha sido uno de los caballos de batalla contra la desigualdad injusta que han sufrido históricamente los discapacitados. P3:279

\section{DESVENTAJA}

Las personas que padecen algún tipo de deficiencia visual, ya sea total o parcial, se encuentran en desventaja a la hora de interactuar con los medios informáticos, cuando pretenden acceder, y sobre todo, tratar, la información deseada. P37:788 


\section{DIFICULTAD}

El diseño para todos es un término del que se habla mucho estos últimos tiempos y que, aunque es a veces una realidad que pasa desapercibida (todos cabemos por las puertas de entrada en casa), también es olvidada con frecuencia (¿̇quién ha inventado esos teléfonos móviles tan pequeños que apenas se pueden manejar?). P6:211

Razones por las que no está satisfecho con los servicios que tiene contratados para el teléfono convencional (...) Complicados... P5:351

El uso inadecuado de marcadores para una presentación (p. ej. utilizando una tabla para maquetar o un encabezado -etiqueta $\mathrm{H}$ - para cambiar el tamaño de la fuente) dificulta que los usuarios con software especializado entiendan la organización de la página o cómo navegar por ella. P37:1064

La presentación en pantalla de documentos web ofrece dificultades de accesibilidad, sobre todo a personas con discapacidad visual, por la orientación multimedia que tiene, pero en la norma se explota el concepto multimedia desde otro punto de vista: redundancia de canales. P37:1242

Por ejemplo, para los ciegos y las personas con discapacidad visual es muy difícil, o imposible, acceder a muchos documentos en línea, del tipo de las páginas web, con el tipo de navegadores (con los lectores de pantallas, por ejemplo) y otros dispositivos de ayuda que normalmente usan. P4:372

Hemos crecido acostumbrados a sortear carteles, andamios que producen quebraderos de cabeza a los ciegos y que son casi olímpicas para quienes van en silla de ruedas. Escaleras, escaleras y escaleras hacen la vida imposible no sólo a minusválidos, sino también a embarazadas o a personas mayores. Por no hablar de las barreras comunicativas en los medios para los sordos o los ciegos. Son numerosas las acritudes antisociales fruto de la falta de sensibilidad. P3:279

Internet también tiene sus propias barreras; la utilización de fotografías, por ejemplo, supone un obstáculo para las personas con alguna discapacidad visual, ya que la relevancia de la imagen y los gráficos en este medio dificulta el acceso a los que necesitan el texto para poder navegar. P6:430

Los diseñadores y creadores de páginas de Internet contarán así con una guía de reglas relativas al contenido, estructura y codificación de los sitios que eliminan la mayor parte de los obstáculos con los que hoy en día cuenta la Red. P6:445 
Los obstáculos que los navegadores de Internet, los contenidos digitales y los ordenadores representan para las personas con discapacidad a la hora de acceder a la administración electrónica deberán ser solventados... P18:485

\section{ESTRESANTE}

El teletexto, que sería uno de los elementos claves para la supresión de barreras de comunicación, no funciona como debería, llegando en ocasiones a ser tan estresante como leer un libro al que tu sobrinito ha arrancado una hoja por aquí, parte de otra por allá. P33:880

\section{9. $\quad$ EXCESO}

.. la cada vez más abrumadora cantidad de información, recursos y servicios que sobre discapacidad dispone Internet. P4:307

\section{EXCLUSIÓN}

Existen desviaciones conocidas como "brechas digitales" que generan el riesgo de la "infoexclusión". P10:383

Si tenemos en cuenta la economía de las personas con discapacidad o personas mayores, entenderemos que el acceso a esta tecnología está limitada... P37:235

... barreras que impiden la utilización de Internet por parte de los discapacitados. P4:388

...la Sociedad de la Información y las Nuevas Tecnologías no deben generar nuevas barreras de exclusión y discriminación... P9:177

... colectivos en riesgo de exclusión digital: personas mayores, con discapacidad e inmigrantes y amas de casa. P28:572

Este tipo de comunicaciones, basadas casi únicamente en la telefonía móvil, ha dejado al margen a un importante colectivo de posibles usuarios integrado por las personas sordas. P37:871

...aunque el mercado está disponible en una tecla del ordenador, en palabras de Yanis Vardakastanis, queda mucho por hacer para evitar la info-exclusión, según Judy Brewer, directora de la Web Accesibility Iniciative (WAI) en el WWW Consortium. P5:627

Un número considerable de cines adapta parte de sus instalaciones pero al no hacerlo de forma completa ofrecen una solución discriminatoria. $\mathrm{P} 7: 554$ 
Las personas con discapacidades y las personas de edad se enfrentan a toda una serie de barreras técnicas a la hora de acceder a Internet. $\mathrm{P} 4: 369$

Nuevas tecnologías o sistemas domóticos son dos términos que todavía un segmento de la población no comprende, existe un grupo poblacional con más de 50 años que se sienten discriminados ante la tecnología. P31:190

\section{INADECUADO}

Ocurría que las adaptaciones que hemos llamado artesanales eran difícilmente adaptables a los nuevos dispositivos y programas, frecuentemente debido a las diferencias en el hardware o en el sistema operativo. Por otro lado, estos diseños solían ser difíciles de adaptar a personas con las mismas necesidades pero con diferentes características físicas. P37:154

Otras variantes de Braille utilizadas en el pasado y que fueron descartadas, entre otros motivos, por un inadecuado uso de la tecnología asociada... P37:799

Aunque la mayoría de los desniveles en el exterior se resuelven con rampas, éstas están mal DISEÑADAS. P7:540

En los 10 últimos años se ha producido una gran expansión de dispositivos electrónicos portátiles que han puesto en evidencia problemas de usabilidad que en otros sistemas habían pasado inadvertidos. P37:687

\section{INCOMPATIBILIDAD}

Estas tecnologías abarcan un espectro tan amplio de campos tecnológicos y científicos que las aplicaciones inadecuadas están causando más de una brecha digital, entre otras razones, por su dificultad de uso, a causa de la carencia de criterios de diseño y por la incompatibilidad entre dispositivos. P32:255

\section{INCOMPLETO}

... su dificultad de uso, a causa de la carencia de criterios de diseño y por la incompatibilidad entre dispositivos. P3 1:255

...con pocas prestaciones en la actualidad (Teléfono de Textos.) P7:559 


\section{INEFICIENCIA}

También puedo citar la radio, la información no me llega, los subtítulos de la tele funcionan muy mal, o a veces ni funcionan, también hay que destacar que no todos los programas están subtitulados. P33:844

Razones por las que no está satisfecho con los servicios que tiene contratados para el teléfono convencional (...) Mal funcionamiento... P5:350

El teletexto, que sería uno de los elementos claves para la supresión de barreras de comunicación, no funciona como debería... P33:880

Las rampas de los autobuses, o no hay o no funcionan. P33:927

\section{INJUSTO}

La eliminación de barreras arquitectónicas ha sido uno de los caballos de batalla contra la desigualdad injusta que han sufrido históricamente los discapacitados. Hemos crecido acostumbrados a sortear carteles, andamios que producen quebraderos de cabeza a los ciegos y que son casi olímpicas para quienes van en silla de ruedas. P3:279

\section{INSEGURIDAD}

...mal uso de los datos personales por el sector de la informática. P36:74

En primer lugar, existían soluciones técnicas, pero su fiabilidad era inaceptable. P33:829

\section{INSUFICIENCIA}

...ni las prótesis ni las ayudas técnicas más sofisticadas, ni los mejores profesionales, serán nunca suficientes... P34:1349

\section{MIEDO}

...que los nuevos usuarios pierdan el miedo a esta tecnología y la incorporen a su vida cotidiana. P9:253

\section{MOLESTIA}

... situaciones de malestar: molestias de aparatos ortopédicos, dolor, fiebre, etc. P30:335 


\section{NOCIVO}

La compatibilidad debe también ser probada para evitar que ciertos productos utilizados por las personas con discapacidad tengan efectos nocivos -interferencias electromagnéticas de los teléfonos móviles y de los audífonos, por ejemplo. P36:735

\section{OBSOLETO}

Sin embargo, la rápida evolución de la informática hizo que los dispositivos y programas desarrollados quedaran obsoletos en poco tiempo, condenando a las personas con discapacidad a utilizar ordenadores "prehistóricos" hasta que resultaban absolutamente no operativos. P37:153

En concreto, se plantean soluciones poco adecuadas y técnicamente superadas, especialmente en lo relativo a la instalación y seguridad de las sillas de ruedas a bordo de los vehículos. P28:374

\section{PROBLEMA}

El plan Wisdom va a investigar los problemas que tienen los sordos con los teléfonos móviles y la aplicación de las más avanzadas técnicas para desarrollar nuevos métodos de interacción. P3:51

El diseño de los autobuses de plataforma baja ha mejorado el acceso para personas con movilidad reducida, pero presenta problemas para usuarios de sillas de ruedas, debido a problemas técnicos. P7:553

El ratón, otro dispositivo utilizado para la entrada de datos, también plantea problemas. P17:163

Pier et al, por ejemplo, analizan los problemas que tienen los displays pequeños y proponen métodos para abordar estas dificultades. P37:681

Hay que destacar también que el sistema de navegación a través de menús presenta los mismos problemas que se han detectado en dispositivos de telecomunicación portátiles basados en tecnología WAP. P37:720

\section{RECHAZO}

... la [silla de ruedas] eléctrica no me gusta" P26:129 
...muchas personas mayores sienten rechazo a los productos con diseño universal al entender que son artículos ortopédicos o paramédicos. P23:613

... evitar la "tecnofobia" y para facilitar el mantenimiento de los sistemas. P10:399

\section{RIESGO}

...porque si se sube una silla de ruedas sin anclar y el coche frena se convierte en un peligro para todos los viajeros y para él mismo. P16:59

La revolución de la tecnología de la información aporta muchas ventajas, pero también conlleva el riesgo de excluir a una parte de la población. P6:393

\section{SEDENTARISMO}

Hoy en día ciertos factores influyen decisivamente sobre el estado de salud de los individuos (...)el sedentarismo (televisor, vídeo casero...) $\mathrm{P} 4: 292$

\section{VALORES DESEADOS}

\section{VD ACCESIBILIDAD}

... animar a creadores de contenidos, diseñadores de sitios web y personal de asistencia técnica a utilizar los mecanismos y especificaciones existentes y a garantizar la accesibilidad de sitios y contenidos. P4:394

Para las niñas y mujeres con discapacidad física se debe asegurar la accesibilidad a los contenidos, servicios, tecnologías y entornos, así como proveer de las ayudas técnicas necesarias. P10:407

...mejorar la accesibilidad, promover la cultura del diseño para todos y suprimir las barreras... P10:626

Lograr que las personas con discapacidad puedan acceder mejor a las nuevas tecnologías y contribuir a reducir la llamada "brecha digital" constituyen fines primordiales del Aula de Accesibilidad a las Nuevas Tecnologías... P22:558 
Mediante la realización de actividades de interés común se promoverá la accesibilidad web... P24:51

Desde este punto de vista, este acuerdo colaborará para concienciar a los fabricantes de teléfonos móviles sobre la necesidad de incorporar el concepto de "Diseño para todos" en el desarrollo de los nuevos dispositivos, de manera que se mejore su accesibilidad y usabilidad. P29:731

Favorecer la accesibilidad en los autobuses de las líneas regulares de carácter público urbano durante 2006, y eliminar las barreras para las personas con discapacidad fue el objetivo del acuerdo firmado. P30:538

La Administración ha sabido apoyar la accesibilidad en los distintos ámbitos arquitectónicos, urbanísticos, de transporte y comunicación y aun teniendo más dificultades por optar por unas tecnologías $u$ otras debe poner todos los medios para exigir accesibilidad a las telecomunicaciones. P37:928

Las páginas y los sitios web deben ser accesibles siguiendo las pautas de la Web Accessibility Initiative. P10:391

Debe instarse a las organizaciones que reciban fondos públicos de las instituciones europeas o los Estados miembros a hacer que sus sitios web sean accesibles. P4:442

El comité Español de representantes de Minusválidos (CERMI) ha solicitado a la Federación de Distribuidores Cinematográficos (FEDICINE) que todos los productos audiovisuales que distribuye cine, video o DVD, sean accesibles. P12:687

\section{VD ADECUACIÓN}

La atención a las personas con discapacidad, y a los mayores, debe permitir un acercamiento más adecuado de la tecnología a las diferentes necesidades y expectativas en beneficio de toda la colectividad. P1 4:468

...diseñar interfaces enfocadas a la navegación autónoma de una silla de ruedas de tracción con el fin de que dichas interfaces sean más adecuadas... P37:664

\section{VD AGRADABLE}

Nuestra relación con la máquina o los sistemas debe hacerse de forma agradable y confortable. P3 1:423 
...necesitan que esos aparatos estén diseñados de manera tan atrayente y aceptable como sea posible. P36:728

\section{VD ASEQUIBLE}

... la comunicación accesible a través de nuevas tecnologías asequibles... P5:662

...la importancia que tiene que las nuevas tecnologías sean accesibles y asequibles para la inmensa mayoría de los ciudadanos. P14:384

\section{VD BARATO}

Además, la interfaz ha de ser de bajo coste económico... P37:693

...beneficiaría a todos los usuarios al disponer de una gama más amplia de productos a precios asequibles. P26:642

\section{VD BRINDAR FACILIDADES}

La incorporación de una rampa o elevador a los autobuses y autocares de la Unión Europea, será una condición indispensable establecida mediante un acuerdo negociado entre el Consejo y el Parlamento en materia de accesibilidad para facilitar el acceso de las personas discapacitadas a este sistema de transporte. P3:642

...también podrán aplicarse a las actividades de generación de software avanzado que faciliten el acceso de personas con discapacidad a los servicios de la sociedad de la información. P16:514

Fomentar la implantación de tecnologías que faciliten el acceso de las personas con discapacidad a los servicios de la Sociedad de la Información... P24:676

\section{VD COMODIDAD}

Nuestra relación con la máquina o los sistemas debe hacerse de forma agradable y confortable. P31:423

Las mujeres con discapacidad deben poder usar los servicios electrónicos con seguridad y confort. P10:390

\section{VD COMPATIBILIDAD}

La compatibilidad de los productos que algunas personas con discapacidad necesitan utilizar junto con otros debe estar garantizada, de manera que puedan funcionar en armonía; por ejemplo, el terminal de 
un cajero automático bancario debe poder ser fácilmente conectado a una tablilla en braille. P36:734

La compatibilidad debe también ser probada para evitar que ciertos productos utilizados por las personas con discapacidad tengan efectos nocivos... P36:735

\section{VD CONFIANZA}

... cuando dispongamos de sistemas fiables y estables e interfaces naturales, cuando los espacios sean ínter operables y sean interfaces en sí mismos (espacios inteligentes), alcanzaremos una fácil comunicación humana... P31:201

\section{VD EFICIENCIA}

Utilidad, eficiencia y flexibilidad. Una premisa irrenunciable, e independiente de adyacentes cuestiones de mercado, es que los sistemas de hogar digital mejoren la calidad de vida de sus usuarios. P31:327

Los servicios domóticos deben ser accesibles para todos los usuarios, y su utilización debe resultar eficiente y fácil de aprender. P31:331

\section{VD IGUALDAD}

... un Sistema informatizado que garantice la uniformidad y equidad de las prestaciones. P2:200

Este Cibercafé pionero destinado a personas ciegas nace con el propósito de satisfacer la necesidad de igualdad de oportunidades... P10:774

Aboga, por ejemplo, porque una tecnología existente (un teléfono móvil) sea utilizable por todos... P33:986

\section{VD INDEPENDENCIA}

Las Nuevas Tecnologías, especialmente las relacionadas con la Informática y las Comunicaciones, deben contribuir a una mayor autonomía de las personas con discapacidad. P37:7

INTERNET se ha convertido para estas personas en una herramienta de comunicación e información que debe contribuir a una mayor autonomía y relación en las diferentes esferas de la vida. P37:71

Pues todavía se puede pedir, por ejemplo, una muleta que facilite el desplazamiento por un terreno irregular como la arena de las personas con problemas de movilidad... P13:841 


\section{VD INTEGRACIÓN}

Entre éstas, velar por que el Sexto Programa marco de Investigación y Desarrollo tecnológico 2003- 2006 apoye acciones de fomento a la integración social con tecnologías electrónicas... P1 1:841

"Tu ayuda tiene premio" es el lema de la campaña del portal Pymes de Microsoft Argentina para contribuir a la inclusión digital de personas y comunidades salvadoreñas. P27:677

... asegurar que los materiales multimedia y el uso de TIC en la educación no creen nuevas barreras contra la integración de estudiantes con discapacidad. P1 1:840

\section{VD INTELIGENCIA}

Ubicuidad, transparencia e inteligencia son las tres propiedades básicas de los ambientes inteligentes: ubicuidad para encontrarlos en el punto donde esté la persona, transparencia para pasar inadvertidos en el medio físico e inteligencia para adaptarse a las preferencias de cada persona. P31:405

\section{VD NATURAL}

Cuando consigamos que la tecnología cotidiana esté perfectamente integrada en el entorno: volviéndose invisible para el usuario, con una infraestructura de comunicaciones móvil/fijo interactiva y sin transiciones; cuando dispongamos de sistemas fiables y estables e interfaces naturales, cuando los espacios sean inter operables y sean interfaces en sí mismos (espacios inteligentes), alcanzaremos una fácil comunicación humana... P31:201

\section{VD MEJORA}

... conseguir que las nuevas tecnologías permitan superar las condiciones de discapacidad y pobreza de estos colectivos. P22:679

\section{VD SEGURIDAD}

Las mujeres con discapacidad deben poder usar los servicios electrónicos con seguridad y confort. P10:390

\section{VD SENCILLEZ}

Los servicios domóticos deben ser accesibles para todos los usuarios, y su utilización debe resultar eficiente y fácil de aprender. P31:331 
Las directrices principales de la norma orientan a la fabricación de productos más fáciles de utilizar por parte de cualquier usuario. P37:1 188

... incrementar la facilidad de uso de los servicios de voz IP a personas con un escaso grado de movilidad. P2 1:900

\section{VD ÚTIL}

Lograr que la tecnología informática y los recursos sean útiles para todos los colectivos activos en la sociedad, entre éstos, las personas con discapacidad... P3:564

20. VD VERSATILIDAD

Utilidad, eficiencia y flexibilidad. Una premisa irrenunciable, e independiente de adyacentes cuestiones de mercado, es que los sistemas de hogar digital mejoren la calidad de vida de sus usuarios. P31:327 


\section{CÓDIGOS DE LAS REVISTAS}

\begin{tabular}{|c|c|c|c|}
\hline P1 & Dossier Proyecto EASTIN. FECHA & P21 & $\begin{array}{l}\text { № 148. Noviembre - Diciembre } \\
2004\end{array}$ \\
\hline P2 & Especial Agosto 2005 & $\mathrm{P} 22$ & № 149. Enero - Febrero 2005 \\
\hline P3 & № 130. Septiembre - Octubre 2001 & $\mathrm{P} 23$ & № 150. Marzo - Abril 2005 \\
\hline P4 & № 131. Noviembre - Diciembre 2001 & P24 & № 151. Mayo - Junio 2005 \\
\hline P5 & № 132. Enero - Febrero 2002 & P25 & № 152. Julio - Agosto 2005 \\
\hline P6 & № 133. Marzo - Abril 2002 & $\mathrm{P} 26$ & № 153. Septiembre - Octubre 2005 \\
\hline P7 & № 134. Mayo - Junio 2002 & P27 & $\begin{array}{l}\text { № 154. Noviembre - Diciembre } \\
2005\end{array}$ \\
\hline P9 & № 136. Septiembre - Octubre 2002 & P28 & № 155. Enero - Febrero 2006 \\
\hline P10 & № 137. Noviembre - Diciembre 2002 & P29 & № 156. Marzo - Abril 2006 \\
\hline P11 & № 138. Enero - Febrero 2003 & P30 & № 157. Mayo - Junio 2006 \\
\hline P12 & № 139. Marzo - Mayo 2003 & P31 & № 158. Julio - Agosto 2006 \\
\hline P13 & № 140. Junio - Julio 2003 & P32 & $\begin{array}{l}\text { Especial } 25 \text { años del IMSERSO. } \\
\text { Diciembre } 2003\end{array}$ \\
\hline P14 & № 141. Agosto - Septiembre 2003 & P33 & $\begin{array}{l}\text { Especial La Accesibilidad. Abril } \\
2004\end{array}$ \\
\hline P15 & № 142. Octubre - Diciembre 2003 & P34 & $\begin{array}{l}\text { Especial Atención Temprana. Marzo } \\
2003\end{array}$ \\
\hline P16 & № 143. Enero - Febrero 2004 & P35 & $\begin{array}{l}\text { Especial Daño Cerebral. Diciembre } \\
2002\end{array}$ \\
\hline P17 & № 144. Marzo - Abril 2004 & P36 & $\begin{array}{l}\text { Especial La Discapacidad en } \\
\text { Europa. Mayo } 2003\end{array}$ \\
\hline P18 & № 145. Mayo - Junio 2004 & P37 & $\begin{array}{l}\text { Especial Discapacidad y Nuevas } \\
\text { Tecnologías. Junio } 2002\end{array}$ \\
\hline P19 & № 146. Julio - Agosto 2004 & P38 & № 135. Julio - Agosto 2002 \\
\hline $\mathrm{P} 20$ & № 147. Septiembre - Octubr & & \\
\hline
\end{tabular}


ANEXO 3

EJEMPLOS SIGNIFICATIVOS EN LA PRENSA (EL PAÍS Y EL
MUNDO 2002-2005)

- CUlTURA CIENTÍFICO-TECNOLÓGICA

- IMÁGENES Y VALORES

\section{A. CULTURA CIENTÍFICO-TECNOLÓGICA}

\section{A.1 Cultura Científica Representacional Intrínseca}

ID 344 [P7:03] Actualmente, no se dispone de tratamiento eficaz frente a la infección la mortalidad ronda el $30 \%$ cuando se manifiesta de forma grave. Las secuelas en los que sobreviven son profundas cicatrices y riesgo de ceguera. Los expertos subrayan que estas cifras corresponden a hace casi 30 años, antes de la erradicación, y que los avances que ha experimentado la asistencia sanitaria en este tiempo pueden suavizar este pronóstico.

ID 364 [P8:06] Los últimos datos sobre 100.000 nacimientos (el 27\% de los alumbramientos en 2001) arrojan 1.175 niños malformados. En España viven 32.000 personas con estas alteraciones. Las más frecuentes son las cardiopatías (12 por 10.000 bebés), seguidas de las genitourinarias y las musculoesqueléticas.

ID 5039 [P14:22] De hecho, esta forma de afrontar o de detener la pérdida de facultades provocada por el Alzheimer encaja con las últimas investigaciones que demuestran que mantener cierta actividad mental retrasa el empeoramiento.

ID 5218 [P16:23] "Cada zona del cerebro tiene una señal eléctrica característica", asegura el doctor Obeso. "Podemos traducir esa señal a sonido, de forma que muchas veces nos basta con escuchar el ruido de las neuronas para saber si se está avanzando de una forma correcta. Así, la neurona del núcleo subtalámico tiene un sonido característico".

ID 5218 [P16:11] En sus inicios, el mal se trata bien con fármacos. La levodopa es el compuesto que consumen todos los afectados de Parkinson, ya que la droga, al metabolizarse, se transforma en dopamina, y frena durante un determinado tiempo buena parte de los síntomas. Lo que ocurre es que la enfermedad casi siempre progresa y los beneficios de la medicación acaban diluyéndose. Las dosis de fármaco 
que inicialmente fueron efectivas pierden fuerza con el paso de los años y la duración de la acción de cada toma es cada vez menor.

ID 590 [P17:09] Tal y como explicó a este diario José Carmena, «el cerebro logra incorporar el robot a su propio espacio neuronal». Los macacos tenían feedback visual de lo que estaban haciendo, es decir, contemplaban en una pantalla los movimientos de un cursor, análogos a los del brazo artificial que controlaban.

ID 4746 [P30:14[ La intervención (denominada cifoplastia) la realizó por primera vez un médico estadounidense, Mark Reiley, en 1998. Se trata de recolocar la fractura (es decir, levantar la vértebra rota) y después 'rellenarla' con un cemento (polimetilmetacrilato), que es el mismo «que se emplea en ortopedia para rellenar defectos óseos o fijar las prótesis articulares», precisa una revisión de la 'Revista Española de Reumatología'.

ID 4746 [P30:50] Hasta ahora, el tratamiento del dolor de espalda discogénico (ocasionado por una alteración de los discos intervertebrales) sólo era el consumo de analgésicos y, en caso necesario, recurrir a la fusión vertebral. Pero en los últimos tiempos ha surgido una nueva intervención que aplica calor en los discos intervertebrales mediante un catéter (terapia electrotermal intradiscal) y así destruye las fibras nerviosas de la parte externa del disco ('annulus'). Según el artículo, esta técnica «está emergiendo como una útil opción terapéutica para pacientes seleccionados».

ID 3528 [P34:03] La niña padecía un raro desorden genético, el PANK 2 o síndrome de Hallervorden-Spatz, que la tenía confinada en una silla de ruedas. Cuando Amber intentaba hacer cualquier movimiento, sus brazos se agitaban desordenadamente, golpeándose con ellos en la cabeza una y otra vez.

ID 3537 [P36:08] Los estudios en animales han demostrado que los implantes de células pueden restablecer las funciones nerviosas. Las ratas con nervios seccionados han recuperado las funciones de una pata delantera. Pero el primer estudio humano, que prueba la seguridad del proceso, se limitará a pacientes con una lesión muy específica y similar para asegurar que los resultados sean definitivos.

ID 3537 [P36:16] ¿̇Qué clase de células se van a utilizar en esta operación para intentar reparar los daños nerviosos? Son células nasales. El importantísimo descubrimiento que se hizo en 1985 mostraba que en una sección del sistema nervioso, una parte de la cavidad nasal concerniente al olfato, las fibras nerviosas están en constante crecimiento, incluso en los adultos. Aunque la gente resfriada pierde el sentido del olfato, lo recupera cuando el enfriamiento pasa. 
ID 3552 [P37:02] El genoma del mejor amigo del hombre ha dejado de ser un misterio, al menos al $99 \%$. Un equipo de investigadores del Instituto Broad del MIT y Harvard ha desvelado el mapa genético del perro (Canis familiaris), en concreto de una boxer Ilamada Tasha. El análisis de sus 19.300 genes -el ser humano tiene unos 20.000- ayudará a desentrañar el origen genético de las muchas enfermedades que compartimos ambas especies, como el cáncer, la diabetes, la ceguera, la artritis o las alergias.

ID 3805 [P41:03] En el experimento, realizado junto a científicos del Laboratorio Europeo de Biología Molecular, se utilizaron embriones de pollos y de peces mutados, puesto que el ojo de todos los animales vertebrados es muy similar: un besugo y un hombre tienen los mismos siete componentes celulares en este órgano.

ID 3805 [P41:08] Los FGF (fibroblastos) son proteínas que se expresan en éste y otros tejidos humanos, como el sistema nervioso y la formación del oído, los dientes y las extremidades. Sin embargo, Bovolenta no ha estudiado aún si el mismo mecanismo que desencadenan en la retina se repite en estas otras partes del cuerpo.

ID 4670 [P47:08] Cada seis minutos muere una persona en el mundo por su causa. Es el primer motivo de fallecimiento por infarto de miocardio y hemorragia cerebral. También es la principal causa de ceguera e insuficiencia renal crónica en los países desarrollados. De hecho, el 23\% de los enfermos en diálisis es diabético y, además, quienes la padecen tienen entre un $15 \%$ y un $40 \%$ más de probabilidades de sufrir amputaciones. Su impacto también se deja sentir en la economía sanitaria: los diabéticos ingresan en el hospital tres veces más que sus conciudadanos sanos y, en España, generan anualmente el 7\% del gasto sanitario total.

ID 857 [P55:04] Para crecer tras el accidente que produce la lesión, las fibras nerviosas tienen que sortear (en el espacio entre células por donde pueden crecer hasta reencontrarse con las del otro lado) un laberinto de moléculas, algunas de las cuales están ancladas en las paredes celulares y otras se hallan simplemente libres. Entre estas últimas figuran unas de forma alargada, con apéndices perpendiculares. Una enzima de la bacteria Proteus vulgaris elimina estos apéndices, dejando el camino más libre para el crecimiento de las fibras nerviosas.

ID 953 [P59:09] Pero entonces, ¿̇serviría cualquier pequeño conjunto de neuronas para ejecutar cualquier tarea, provisto el aprendizaje necesario? Schwartz respondió ayer a este diario: 'Las neuronas de esa zona están normalmente implicadas en dirigir el movimiento del brazo, de modo que un comportamiento parecido a ése les resulta más fácil de aprender. No sé si esas mismas neuronas podrían ser condicionadas para otro tipo de 
tareas, pero probablemente es una cuestión de cuánto aprendizaje y condicionamiento se aplique'.

ID 1188 [P60:06] Un ictus o accidente cerebrovascular puede producirse por un coágulo que obstruye el vaso sanguíneo (ictus isquémico) o por una rotura de dicho vaso (ictus hemorrágico). El resultado final es el mismo: una zona del cerebro queda privada de riego sanguíneo. Si la privación es severa y prolongada se produce, como consecuencia del ictus, un infarto cerebral, es decir, la muerte de las células que han dejado de recibir aporte sanguíneo. Como consecuencia de todo ello se puede producir la muerte del paciente o alguna discapacidad.

ID 1337 [P61:03] "El cromosoma humano 7, el más largo de los 24 que componen la dotación genética del hombre, ha sido secuenciado en un $99 \%$ y todos los datos se han puesto a disposición del uso público en el Proyecto Genoma Humano. La secuencia, realizada y analizada por un equipo internacional liderado por el estadounidense Richard K. Wilson, se publica hoy en la revista Nature. "'"El cromosoma 7 ha recibido históricamente una atención especial en la comunidad de genética humana'"', recuerdan los investigadores, ya que se le ha relacionado en muchos estudios con enfermedades como la fibrosis quística, la ceguera hereditaria y varias formas de cáncer."

ID 1369 [P62:10] La osteogénesis imperfecta se produce por un defecto de síntesis de colágeno que afecta a los huesos y a otras estructuras. Se caracteriza por la aparición de huesos largos y sin curvas que se acompañan de otros problemas de tipo hormonal, dermatológico y que, a veces, se presenta también con sordera, conocida entre los especialistas como sordera de conducción, porque se deforman los huesos del conducto auditivo. Otros síntomas son dientes anacarados, problemas de digestión, ligamentos laxos o hernias discales.

ID 1743 [P65:01] El síndrome de Sanfilippo, según el presidente de la asociación, Jordi Cruz, es una enfermedad muy poco frecuente, de la que en España se han diagnosticado en los últimos años unos 50 casos. Está causada por una disfunción del metabolismo originada por la falta de una enzima que degrada los mucopolisacáridos (carbohidratos complejos) a moléculas más simples. La falta de esta enzima origina que los mucopolisacáridos se acumulen en las células de todos los órganos, especialmente en el cerebro, y causa multitud de anomalías físicas, siendo una de las más visibles un retraso mental profundo, aunque también puede derivar en ceguera, inmovilidad (la mayoría acaba en silla de ruedas) e incomunicación total. La enfermedad afecta a uno de cada 24.000 niños en todo el mundo.

ID 5183 [P82:05] Algunos de ellos se manifiestan en la infancia (amiotrofia espinal infantil, osteogénesis imperfecta, condrodísplasias o 
síndrome de Rett) y en más del $50 \%$ de los casos aparecen en la edad adulta (enfermedad de Huntington, enfermedad de Charcot-Marie-Tooth, esclerosis lateral amiatrófica). Algunas de estas enfermedades se encuentran en el límite de la clasificación por tener una frecuencia más alta (ciertos tipos de esclerosis, de autismos, de enanismo...), otras son sumamente minoritarias (enfermedad de Gaucher, enfermedad de FabryAnderson, ciertas ataxias, enfermedad de Creutzfeld-Jacob y síndrome de MacCune Albright) y entre todas no suman más de un centenar de pacientes en España.

ID 5183 [P82:42] El síndrome de Apert produce malformaciones en el cráneo, la cara, las manos y los pies, y trastornos funcionales que varían de un paciente a otro. Son niños con una fisonomía craneofacial característica y a los que a menudo pueden faltar o aparecer unidos los dedos de manos y pies. Afecta a un caso entre cada 160.000 y su causa es una mutación en el gen FGFR2.

ID 2880 [P85:02] La última curiosidad sobre este lenguaje de silbidos se descubre hoy en la prestigiosa revista científica Nature: unos investigadores de Canarias han descubierto que en el cerebro de los silbadores gomeros, al emitir los silbidos, se activan exactamente las mismas zonas implicadas en el lenguaje hablado o incluso el lenguaje por señas de los sordos.

ID 3473 [P101:03] Pese a su aparente levedad, el potencial dañino del virus es enorme. E irreversible. Si una mujer embarazada contrae la rubeola en los tres primeros meses de gestación, el feto sufrirá malformaciones congénitas (ceguera, retraso mental, trastornos cardíacos $u$ otras dolencias, denominadas en su conjunto síndrome de la rubeola congénita) en más del $80 \%$ de los casos.

\section{A.2 Cultura Científica Representacional Extrínseca}

ID 5218 [P16:09] Se informó cuanto pudo. Le dijeron que la operación era compleja y que sólo una veintena de hospitales en España la llevaban a cabo. Alguien le habló de la Clínica Universitaria de Pamplona, uno de los lugares con más experiencia en el mundo con esta cirugía. Pidió referencias. Las encontró. Bastó repasar la literatura médica para comprobar que los doctores José Obeso y Mari Cruz Rodríguez Oroz, los neurólogos de Pamplona que coordinan allí la estimulación eléctrica profunda en el cerebro para paliar el Parkinson, forman parte del grupo que más y mejor ha publicado sobre esta operación.

ID 590 [P17:15] De momento, y aunque los resultados son "prometedores», aún queda "un largo camino» hasta lograr que este sistema funcione con humanos, según reconocen los propios científicos. 
En cualquier caso, ya está en marcha una investigación para descubrir hasta qué punto los impulsos neuronales de los primates se corresponden con los del hombre.

ID 592 [P18:02] El control de robots mediante impulsos cerebrales está experimentando un rápido desarrollo en los últimos años. Esta tecnología se presenta como una futura solución para los parapléicos, que podrían usar distintos ingenios para desplazarse, agarrar objetos o escribir sobre una pantalla de ordenador.

ID 2784 [P24:04] De hecho, y quien sabe si gracias a ese empeño por realizar aquello en lo que ponía el ojo -«elige la cosa más difícil que crees que puedes llegar a hacer y hazla» era su lema- la fama mundial le llegó a raíz del desarrollo de un invento que permite ver a personas ciegas.

ID 2847 [P27:04] Y aunque sabía, por boca de los galenos, que la mortalidad en este tipo de intervenciones es del $1 \%$, yo confiaba ciegamente en los cirujanos.

ID 2847 [P27:08] «Nunca, desde que salí del quirófano, me han dicho la verdad. Seis meses después de la operación, aquí sigo, más muerto que vivo y sin saber todavía por qué los propios cirujanos que un día me animaron a ponerme en sus manos me han dejado paralítico».

ID 3537 [P36:10] Si tiene éxito, siguiendo con las investigaciones, este proceso podrá probarse en personas en silla de ruedas. También cabe la posibilidad de que puedan curarse otras lesiones nerviosas, como aquellas causadas por apoplejía, ceguera y sordera. "De confirmarse, creo que creará tanta publicidad que tendremos la suerte de continuar en este campo. Será una revolución. Pero lo único que me interesa es la especie humana. Esto tiene un gran futuro pero no creo que yo llegue a verlo acabado", ha declarado el doctor Raisman.

ID 3625 [P38:06] A los 63 años, Hawking ha sobrepasado su esperanza de vida en unos 40 años. Su fama se debe tanto a su enfermedad como a su ciencia, y lo lleva muy bien, ilustrando sus libros con fotos casi de culto, del tipo Dónde está Wally, en las que aparece volando por el espacio en su silla de ruedas y sufriendo las condescendencias de la prensa con serenidad. La sonrisa de Hawking es siempre pícara, su propensión a acribillar a la gente en su silla de ruedas es una broma más que un gesto de mal humor o un signo de que, żquién sabe?, si no estuviera discapacitado, podría ser un gamberro del fútbol. $Y$, aunque su ex mujer le ha llamado tirano y su segunda esposa le ha acusado de maltrato (la denuncia se retiró), el romanticismo de la imagen de Hawking como una mente de mariposa atrapada en una jaula de hierro anula a todas las demás. 
ID 791 [P54:11] "Quienes están a favor ven enormes beneficios en la clonación. Como salvar especies en vías de extinción, fortalecer las razas, crear gatos que no produzcan alergia, mascotas diseñadas especialmente para ayudar a los impedidos, a los ciegos o a la policía; amén del consuelo que puede representar para los amos que pierden a sus acompañantes. 'Es normal que si usted adora a su gato o a su perro quiera tener un doble', apunta Gillespie, quien en los últimos años ha clonado decenas de animales de ganadería que están esparcidos en granjas de todo el país y cuestan 19.000 dólares por ejemplar."

ID 1725 [P64:03] "El viejo sueño de la ciencia ficción de controlar objetos con la mente está más cerca de convertirse en realidad. Un equipo de investigadores en Estados Unidos, del que forma parte un neurobiólogo español, ha logrado que unos monos manipulen un brazo robótico exclusivamente con sus ondas mentales. "'El animal ha integrado el brazo robótico en su cerebro, como si fuera su propio brazo'"', explica José Carmena, principal autor del trabajo que se publica hoy en el primer número de la revista electrónica Public Library of Science. Estos resultados se consideran un gran paso hacia el control mental de prótesis para tetrapléjicos, extremidades paralizadas o robots que circulen de modo autónomo."

ID 3998 [P72:05] "La situación es mucho más grave en los países en desarrollo, donde millones de personas sufren problemas crónicos o discapacidades que hubieran podido evitarse, ello si no mueren por culpa de errores médicos, transfusiones de sangre sin garantías, fármacos falsificados o de calidad inferior a la norma y, sobre todo, prácticas inseguras en condiciones de trabajo precarias"'"', dice Ebrahim Samba, director regional de la OMS para África. La OMS informa de que al menos un $50 \%$ del material médico no es de fiar, y un $77 \%$ de los casos de falsificación o mala calidad de los medicamentos se dan en países en desarrollo."

ID 5180 [P81:01] En El País Semanal del 7 de marzo se publicaba un artículo, en la sección de Nutrición, sobre los fármacos contra la obesidad en el que se hacía referencia a un medicamento llamado siburtramina, medicamento que antes de comercializarse ya se vendía en España. Yo tomé dicho fármaco antes de comercializarse y hoy poseo un certificado más, el de minusvalía. Nadie me informó sobre sus efectos secundarios, ni nadie me dijo que había sido retirado en Italia e Inglaterra. Si alguien tiene algún familiar que vaya a tomar píldoras maravillosas, que busque información en la Red y verá lo que dicen sobre el medicamento. Rogaría a los endocrinos que antes de recetarlas informen de los efectos secundarios al paciente, pues para algunos son más importantes los riesgos que se puedan correr que los kilos que se pueden perder. 
ID 5183 [P82:04] El 80\% de estos procesos es de origen genético, aunque existen otros de causa infecciosa, autoinmune o desconocida. Pero siempre se trata de trastornos graves, crónicos y progresivos, que en algunos casos pueden llegar a ser incompatibles con la vida, pero que en todos ellos suponen, para los pacientes, un largo y duro peregrinaje hasta llegar al diagnóstico adecuado, y para los servicios sanitarios, una importante inversión.

\section{A.3 Cultura Científica Práctica Intrínseca}

ID 5063 [P3:03] El hallazgo de alteraciones en el gen GJB6, que recoge esta semana el 'New England Journal of Medicine', permitirá mejorar el diagnóstico precoz de la pérdida de la audición en niños y facilitará que reciban un tratamiento correcto, así como una educación especial temprana que evite la mudez.

ID 510 [P15:21] La investigación fue publicada en la revista científica Nature.

ID 5218 [P16:09] Bastó repasar la literatura médica para comprobar que los doctores José Obeso y Mari Cruz Rodríguez Oroz, los neurólogos de Pamplona que coordinan allí la estimulación eléctrica profunda en el cerebro para paliar el Parkinson, forman parte del grupo que más y mejor ha publicado sobre esta operación.

ID 5218 [P16:19] Luego se tiene que seguir un protocolo estricto que se inicia con la colocación del marco esterotáxico en la cabeza del paciente.

ID 590 [P17:02] El aparato, que ya se ha probado con éxito en un experimento con monos macacos, sirve para alcanzar y sujetar objetos / Podría utilizarse como prótesis para devolver la movilidad a personas parapléicas

ID 3537 [P36:08] Los estudios en animales han demostrado que los implantes de células pueden restablecer las funciones nerviosas. Las ratas con nervios seccionados han recuperado las funciones de una pata delantera. Pero el primer estudio humano, que prueba la seguridad del proceso, se limitará a pacientes con una lesión muy específica y similar para asegurar que los resultados sean definitivos.

ID 3816 [P43:06] Posteriormente, un estudio ha probado cómo la mente humana puede mover un brazo robótico, utilizando electrodos conectados con el cerebro humano. En este proyecto participa el neurólogo español José Carmena. No obstante, de momento sólo se han hecho pruebas con 
humanos de unos pocos minutos, por lo que no se ha podido verificar los resultados conseguidos con animales.

ID 1725 [P64:05] El trabajo es continuación de otros en que los investigadores procesaban las señales eléctricas del cerebro de monos mientras hacían tareas simples con los brazos, como llevarse comida a la boca.

ID 1725 [P64:11] "La revista en que se publica el trabajo también es una novedad. Se trata de la primera revista publicada por la organización sin ánimo de lucro Public Library of Science, que fomenta el acceso libre a los resultados científicos. Para esta organización, el actual sistema de publicaciones científicas antepone los intereses de las editoriales a los de la comunidad. La revista mantiene el estricto sistema de control de calidad basado en la revisión independiente de los artículos por parte de otros científicos; es gratis y está presidida por el Nobel de Medicina Harold Varmus."

\section{A.4 Cultura Científica Práctica Extrínseca}

ID 378 [P9:02] El Tribunal Supremo ha ratificado la condena impuesta en marzo de 2001 por la Audiencia de Alicante a dos empresarios y un médico que "se aprovecharon de la desesperación» de enfermos incurables para lucrarse.

ID 2643 [P20:01] La secretaria de Estado de Servicios Sociales, Familia y Discapacidad, Amparo Valcarce, anunció ayer la puesta en marcha en Burgos de un centro de referencia nacional para el tratamiento de las llamadas enfermedades raras, que financiará la Administración central.

ID 2784 [P24:07] Los últimos meses de su vida, consciente del grave empeoramiento de su diabetes, los ha dedicado a la búsqueda de un socio para que el Proyecto Visión Artificial no se quede estancado por falta de financiación.

ID 4746 [P30:31] El precio parece otro de los inconvenientes de la intervención. Mientras el coste de la vertebroplastia es de unos 1.000 euros, la nueva intervención cuesta cuatro veces más (unos 4.000), lo que explica que algunos centros públicos todavía opten por la primera.

ID 3529 [P35:09] Así, anunció que las deducciones por invertir en I+D+i irán «disminuyendo progresivamente en beneficio de la reducción de los tipos impositivos». Ocurrirá lo mismo con las deducciones por contratar minusválidos o las que se destinan a la internacionalización de las empresas. 
ID 3529 [P35:10] En opinión de la dirigente socialista, «es más eficaz la política directa de apoyo al I+D+i que las deducciones fiscales» o estimular la contratación de minusválidos con "políticas activas», porque, dijo, «estamos viendo que se consiguen mejores resultados en esa línea».

ID 3816 [P43:03] La investigación, puesta en marcha por científicos europeos financiados por la UE, realizó sus pruebas con éxito en un paciente, aunque tuvo que sufrir varias y largas operaciones.

ID 4778 [P49:13] El éxito del innovador proyecto dependerá en buena medida de la colaboración de las nueve instituciones que se han implicado en el mismo. Además de las ya citadas, en el programa trabajan varios laboratorios del departamento de Energía de EEUU, que ha aportado seis millones de dólares a la investigación, dos compañías privadas californianas y otras dos universidades más estadounidenses.

ID 1413 [P63:05] - Eutanasia activa. Es la acción que tiene por objetivo (a petición libre y explícita del enfermo) terminar con la vida de una persona con un mal avanzado o terminal, o con una minusvalía grave crónica, que padece sufrimientos vividos como intolerables. En España se pena con tres años de cárcel.

ID 4122 [P73:10] "Sin embargo, como señala Alberto de Pinto, presidente de la Federación Nacional de Asociaciones de Lesionados Medulares (ASPAYM), hace falta una clara voluntad política para mejorar la situación de las personas discapacitadas. "'Hemos pasado del puedo prometer y prometo de Suárez al puedo cumplir, pero no cumplo, de ahora'"', señala este médico retirado, que quedó parapléiico cuando, en 1971, sufrió un accidente de automóvil. Se sobrepuso a la desgracia, estudió y, durante 20 años, ejerció la profesión en el hospital de Toledo, un historial que, sostiene, no debería resultar sorprendente si la sociedad estuviera concienciada. "'Hay un divorcio entre las palabras y la letra impresa de las mil y una normas y su grado de desarrollo y aplicación. Después de todo, ¿̇qué es lo que pedimos? Tan sólo que nuestras limitaciones no supongan un obstáculo insalvable para gozar de las mismas oportunidades que el resto de la gente, en igualdad de justicia y de derechos"'". Contribuir a hacerlo posible es el gran objetivo de la nueva fundación."

ID 5183 [P82:38] "Para curar las constantes heridas de José Andrés, que tiene un $65 \%$ de minusvalía física, la familia soporta un gasto mensual en torno a 500 euros, entre vendas, apósitos, gasas, cremas, geles y vitaminas, que no cubre la Seguridad Social. "'Yo estuve un año luchando por poder acceder a un apósito que no se adhiere a las heridas, y que, por ejemplo, en Cataluña es costeado por la sanidad pública"'", explica José, el padre de José Andrés. "'"Tuve que encerrarme una hora en el despacho del delegado en Córdoba del Servicio Andaluz de Salud para 
conseguirlo. Su argumento consistía en que los recursos financieros sanitarios son limitados. Yo le contesté que se obstinaba en esa excusa porque no se trataba de su hijo"'"."

ID 5183 [P82:06] La razón de agruparlas bajo el mismo epígrafe de enfermedades raras responde a la necesidad de aunar esfuerzos para potenciar la investigación y despertar la conciencia social sobre este grave problema. En los últimos cinco años, la Unión Europea ha mostrado una especial sensibilidad para apoyar la lucha contra estos procesos patológicos tan poco frecuentes. El Parlamento Europeo y la Comisión Europea aprobaron en 1999 un programa que las define como '"'enfermedades con riesgo vital o enfermedades crónicas debilitantes, que tienen una prevalencia tan baja que se hacen necesarios esfuerzos especiales para abordarlas, y poder así prevenir sus complicaciones y mortalidad temprana, la reducción en la calidad de vida de los afectados y el elevado impacto socioeconómico"'"."

ID 3085 [P91:04] Las vacunas de Hilleman también han evitado la sordera, la ceguera y otras discapacidades permanentes entre millones de personas, algo que observó el presidente Ronald Reagan cuando en 1988 le hizo entrega de la Medalla Nacional de la Ciencia, el galardón científico más importante de Estados Unidos.

\section{A.5 Cultura Científica Valorativa Intrínseca}

ID 5218 [P16:16] La neurocirugía se ha usado contra el Parkinson desde los años 50, pero la llegada de la levodopa a principio de los 70 oscureció el paso por el quirófano, algo que, además, nunca se había evaluado con rigor científico.

\section{A.6 Cultura Científica Valorativa Extrínseca}

ID 5218 [P16:17] El revival del bisturí para tratar el Parkinson volvió hace cinco años cuando especialistas de Grenoble, en Francia, demostraron que la estimulación de los ganglios de la base del cráneo era efectiva en los enfermos con patología muy avanzada. Desde entonces, decenas de miles de pacientes en los que la medicación ya no servía -y con síntomas muy incapacitantes- se han beneficiado de esta alternativa terapéutica.

ID 2559 [P19:18] Este es un fascinante y ambicioso campo de estudio que todavía está dando sus primeros pasos, pero que ya ha logrado algunos 
resultados espectaculares en experimentos preliminares con animales y personas.

ID 4746 [P30:44] Además de la cifoplastia, en los últimos años han aparecido otras intervenciones poco agresivas que se proponen aliviar otros males de la espalda. Este tipo de cirugías cuenta con numerosas ventajas (menos días en el hospital y dolor posoperatorio...), «sin embargo, otras técnicas, anunciadas como grandes hitos, no han sido más eficaces, o incluso han resultado inferiores, a los tratamientos existentes. Ahí lo mínimamente invasivo quiere decir mínimamente efectivo», señalaba la mencionada revisión de 'Mayo Clinic Proceedings.' Este trabajo repasa los pros y contras de algunas de ellas.

ID 3528 [P34:10] El doctor Jean Pierre Lin, especialista en neurología pediátrica y responsable del tratamiento, asegura estar sorprendido por el éxito. "Ha sido espectacular. Es más de lo que esperábamos».Para 2006, proyecta tratar a otros niños.

ID 3815 [P42:04] Después de una operación en el Hospital New England Sinai en Massachusetts, Nagle se ha convertido en el primer paciente que participa en un ensayo controvertido sobre implantes cerebrales que podrían ayudar a personas discapacitadas a ser más independientes, mediante la estimulación de sus ondas cerebrales.

ID 2902 [P86:01] Uno de los hitos más relevantes de las últimas décadas en el campo de la otorrinolaringología ha sido el empleo de los implantes cocleares en el tratamiento de la sordera. Esta técnica tiene la potencialidad de cambiar la calidad de vida de las personas que sufren una sordera.

\section{A.7 Cultura Tecnológica Representacional Intrínseca}

ID 5218 [P16:20] Esta compleja corona de metal se fija con tornillos al cráneo y es la base de todas las acciones posteriores. Gracias a ella se pueden introducir hasta el lugar elegido, y con una precisión milimétrica, varillas de metal de diámetro muy pequeño que permitan colocar electrodos, sustancias específicas e incluso células madre.

ID 2784 [P24:06] El ojo artificial consiste en una cámara digital insertada en la lente de unas discretas gafas de sol de las que sale un cable que conecta con un pequeño ordenador que se esconde en el cinturón del paciente. La imagen procesada por el ordenador transmite las señales que estimulan a la corteza cerebral implicada en la visión directamente, sin tener que utilizar el nervio óptico que se supone dañado. Los pacientes ven una serie de puntos luminosos que conforman, a grandes rasgos, una imagen de la realidad. Gracias a ello consiguen una amplia 
independencia en cuanto a movilidad, pero no pueden llegar a realizar tareas de mayor precisión como leer. El invento se usa hoy con normalidad y funciona con personas que han perdido la vista de manera traumática y a las que no les es posible realizar un trasplante de retina.

ID 4989 [P33:3-9] ONCE y Owasys han trabajado de forma conjunta en el diseño de este terminal para superar todos esos obstáculos. El 22C tiene un sintetizador de voz capaz de leer al usuario el contenido de los mensajes, informarle del estado de cobertura y la carga de la batería o señalarle quién es la persona que le está llamando.

Otros detalles, como las teclas en relieve o el altavoz de alta potencia, facilitarán el manejo a los usuarios. Se comercializará en los puntos de venta de Telefónica Móviles y en las oficinas de la ONCE y su precio será de 400 euros.

FICHA

BANDA. GSM/GPRS 900/1800

VOZ. Sintetizador capaz de leer mensajes de texto, agenda e información del estado del terminal.

BATERÍA. De litio. Ocho horas en conversación y 250 en reposo.

DIMENSIONES. $118 \times 49 \times 27 \mathrm{~mm} .125 \mathrm{gr}$.

ID 3805 [P41:09] Se trata de un chip que se coloca detrás del ojo y está conectado a una minicámara de vídeo insertada en los cristales de las gafas. Las imágenes captadas son enviadas al chip, que las traduce en impulsos eléctricos para que las pueda interpretar el cerebro.

ID 3851 [P44:05] Precisamente por eso, el nuevo reto de estos investigadores ha sido conseguir robots que comiencen a andar por sí mismos, y que la energía de ese primer movimiento sirva para todo el paseo del artilugio. Y lo han hecho de formas distintas, con pequeños microchips o motores eléctricos que dan el primer impulso para lanzar el paso. Luego, el robot prácticamente anda solo.

ID 4778 [P49:05] La 'retina artificial', nombre con el que se conoce popularmente al dispositivo, es una prótesis microelectrónica diseñada para sustituir a las células dañadas por enfermedades como la retinosis pigmentaria o la degeneración macular, dolencias que causan ceguera $\circ$ graves deficiencias visuales y afectan a más de 25 millones de personas en todo el mundo. El implante mide apenas unos milímetros y se inserta quirúrgicamente en el fondo de la retina. Está integrado por 16 electrodos y funciona cuando éstos reciben la información visual que capta una diminuta cámara instalada en unas gafas especiales.

ID 4778 [P49:06] La señal se transmite a los electrodos sin necesidad de cables a través de un receptor que se implanta detrás de la oreja durante la misma operación quirúrgica. Cuando el dispositivo recibe la 
información, estimula a las células sanas residuales que puedan quedar en la retina para que la envíen al cerebro a través del nervio óptico.

ID 769 [P53:03] Un gorro de baño con ocho electrodos colocados estratégicamente, un encefalógrafo, un ordenador y un software basado en las redes neuronales constituyen el equipo portátil con el cual, una vez entrenado, una persona puede escribir con el pensamiento un texto mediante un teclado virtual, manipular una silla robotizada o jugar al popular Pacman.

ID 1809 [P67:08] Los audífonos digitales analizan en la actualidad algo más de 80 parámetros. Entre otros, los que influyen sobre la resolución temporal como el nivel de amplificación y de potencia, el ancho de banda (de 100 hercios a ocho kilohercios), el ajuste de canales (algunos modelos ofrecen una veintena de canales de sonido), la resolución de frecuencia, la compresión de la señal acústica o la resonancia. La suma de todos estos parámetros transforma el audífono en una diminuta caja de mezclas dotada de un analizador de frecuencias a los que pueden, todavía, añadirse un par de micrófonos con los que lograr direccionalidad.

\section{A.8 Cultura Tecnológica Representacional Extrínseca}

ID 121 [P1:01] Investigadores de la Universidad de Brown (EEUU) han desarrollado un sistema para registrar, interpretar y reconstruir la actividad del cerebro que controla el movimiento de las manos, y han demostrado que, sólo con el pensamiento, se puede mover un cursor en una pantalla de ordenador para que llegue a un punto de destino, algo que el futuro podría ser de gran utilidad para las personas que sufren parálisis.

ID 234 [P2:18] «Todos hablan del Gran Hermano. Pero lo que esta tecnología y nosotros representamos es la evolución de la Humanidad». El entusiasmo con el que Jeffrey Jacobs, el padre de la familia con chips bajo su piel, defiende el VeriChip contrasta con las advertencias que ya han hecho los miembros de la comunidad científica. "La tecnología está sobrepasando la capacidad de las autoridades para legislar sobre estos nuevos instrumentos", afirma Steven Aftergood, que recalca que el VeriChip se ha colado aprovechando un vacío legal existente.

ID 590 [P17:02] El aparato, que ya se ha probado con éxito en un experimento con monos macacos, sirve para alcanzar y sujetar objetos. Podría utilizarse como prótesis para devolver la movilidad a personas parapléjicas. 
ID 590 [P17:03] En un futuro próximo, las personas parapléiicas podrán recuperar al menos parte de su movilidad gracias a prótesis robóticas que controlarán con los impulsos de su propio cerebro. Esto es lo que se deduce de las pioneras investigaciones que ha llevado a cabo un científico español en la Universidad de Duke (EEUU).

ID 592 [P18:02] El control de robots mediante impulsos cerebrales está experimentando un rápido desarrollo en los últimos años. Esta tecnología se presenta como una futura solución para los parapléiicos, que podrían usar distintos ingenios para desplazarse, agarrar objetos o escribir sobre una pantalla de ordenador.

ID 2559 [P19:03] El musculobot, como le han denominado sus creadores, podría llegar a solucionar el problema de las personas paralíticas que precisan de un ventilador para respirar, como el caso del actor Christopher Reeve, o reparar los agujeros que provocan los impactos de minúsculos meteoritos en las naves espaciales. En todo caso, se ha abierto la puerta a un mundo de híbridos de la tecnología y la biología que hasta ahora formaban parte de la ciencia ficción.

ID 2559 [P19:17] En los últimos años, la idea de fusionar la biología con la robótica se ha convertido en una nueva utopía médica. Muchos investigadores están convencidos de que, en el futuro, las personas parapléicas podrán recuperar al menos parte de su movilidad gracias a sofisticadas prótesis robóticas y sillas de ruedas controladas por los impulsos neuronales del cerebro humano.

ID 4989 [P33:02] Los usuarios ciegos podían, hasta ahora, utilizar los teléfonos móviles habituales, pero con serias dificultades. No tenían acceso a los mensajes de texto o a la agenda. Incluso las funciones más simples, como consultar el estado de la batería o la hora, eran completamente imposibles para ellos.

ID 3815 [P42:08] Desde entonces, empleando un software conectado a los dispositivos que se encontraban alrededor de él en una habitación, Nagle ha podido encender y apagar su televisión, cambiar de canal y modificar el volumen, gracias al implante. «Finalmente queremos que pueda usarlo para controlar las luces, su teléfono y otros aparatos», afirma Donoghue.

ID 3851 [P44:02] Si para los humanos andar es algo tan sencillo como poner un pie detrás de otro, ¿̇por qué fabricar robots que emplean muchísima más energía para imitar este movimiento, que además nunca está bien logrado? La respuesta la tienen científicos de tres universidades, que han presentado sendos androides capaces de desplazarse de una forma casi idéntica a los humanos, y que además consumen menos energía al hacerlo. 
ID 4778 [P49:02 y 07] Una «retina artificial» devuelve parte de la visión a seis ciegos

La primera 'retina artificial' se implantó en un paciente invidente en el mes de febrero de 2002. Hasta noviembre de 2004 le han seguido otros cinco enfermos, cuyos resultados han sido presentados en la citada reunión de la ARVO. Los participantes están siendo aún objeto de seguimiento.

ID 4598 [P52:01] La red convierte en experto de MP3 a un periodista en silla de ruedas

Una enfermedad obligó a Matías Uribe a comprarse un PC hace seis años y hoy da consejos sobre todo lo que se puede hacer con Internet y un ordenador

ID 3901 [P68:06-08] En una reciente encuesta efectuada entre 227 implantados [implante coclear] apareció que un $44,49 \%$ había obtenido más o mucho más de lo que esperaba, el $10,13 \%$ algo más de lo que esperaba y un $29,96 \%$ lo que esperaba.

El 11,45\% había obtenido casi lo que esperaba y sólo un 3,97\% tenía menos de lo que esperaba o no había obtenido el resultado que esperaba.

Esta encuesta, sobre 72 implantados, está reflejada en el documento de la Agencia de Evaluación de Tecnologías Sanitarias del Ministerio de Sanidad y Consumo.

ID 4314 [P75:14] Cuando se trata de prestar ayuda en un entorno doméstico, la apariencia amigable de una máquina facilita mucho la interacción y su aceptación. A una persona mayor o con discapacidades físicas le resulta más fácil dar órdenes a alguien que le recuerda a un asistente que no a una máquina impersonalizada.

ID 4453 [P79:15] Si hace 10 años Nicholas Negroponte, director del Massachusetts Institute of Technology (MIT), se asombraba de que cuando viajaba a Europa tenía que hacerlo con un puñado de enchufes eléctricos para conectar su afeitadora, hoy con la llegada de la tecnología digital, la situación no ha mejorado. En su equipaje, Negroponte debe añadir a los enchufes eléctricos, el cargador de su teléfono, el cargador de su reproductor de DVD, el cargador de su portátil, el cargador de su agenda electrónica, el de su cámara digital... y, si le cabe, una muda limpia.

ID 5171 [P80:01] Ciertamente, en la actualidad, tanto la telefonía móvil como Internet nos ofrecen un sinfín de posibilidades. Si además tenemos en cuenta su accesibilidad -es emocionante ver a los adultos cómo se introducen en eso del correo electrónico en cibertecas públicas-, podremos decir que estamos ante un elemento democratizador de la sociedad. 
ID 3097 [P93:01] Los padres apuestan por la tecnología para conseguir que sus hijos oigan.

\section{A.9 Cultura Tecnológica Práctica Intrínseca}

ID 5218 [P16:24] Bastaron un par de trayectorias en cada hemisferio para colocar los electrodos de estimulación en los núcleos subtalámicos de Adelina. Entonces se hizo pasar por ellos una corriente eléctrica de dos voltios y medio para comprobar que el brazo y la pierna de Adelina dejaban de temblar completamente, y sin efectos secundarios.

ID 5218 [P16:21] Una vez fijado el marco esterotáxico hay que localizar con la ayuda del TAC y la resonancia la situación exacta del objetivo. En el caso de Adelina, las dianas eran los núcleos subtalámicos de la base del cerebro.

ID 2784 [P24:01] De modo que a los 13 años ya había solicitado su primera patente, relacionada con la mejora del diseño de las caderas artificiales que su progenitor y maestro había creado.

ID 3537 [P36:13] «Esta no es la forma más popular de intentar curar lesiones espinales. Lo sería si se fabricaran productos patentados, que las farmacéuticas pudieran fabricar y vender. Lo que proponemos podría realizarlo cualquier hospital equipado con un departamento de neurocirugía. No hay patentes, algo que la convierte en una investigación muy poco popular», argumentó. "Estamos creando un proceso en el que el paciente posee su propia cura. Afortunadamente, no se pueden patentar las propias células de un paciente.»

ID 769 [P53:07] Las señales cerebrales se transmiten a un PC, donde se procesan. Cada medio segundo, la red neuronal artificial, el corazón del sistema, aprende a identificar la actividad eléctrica de cada sujeto en particular según siete estados mentales distintos. Cualquier alteración externa o interna puede afectar al proceso. "No se pretende reconocer el cien por cien de los intentos, sino que no reconozca lo que no es, para evitar las consecuencias', señala. Para personalizar el interfaz, cada usuario debe escoger tres estados mentales de esta lista: mover el brazo derecho o izquierdo, visualizar y hacer rotar un cubo, relajarse o asociar palabras.

ID 951 [P58:06] El funcionamiento de este interfaz es sencillo. El usuario se debe situar ante la cámara, colocada encima del monitor. Una vez que comprueba en una ventanita que aparece en la pantalla que su cara está encuadrada en la imagen, un sistema de reconocimiento la identifica y la separa del fondo a partir del color de la piel. Luego, detecta el punto medio que hay entre los ojos, que se convierte en la marca virtual que 
permitirá al software seguir automáticamente cualquier movimiento de la cabeza.

ID 1725 [P64:07] "En este trabajo se ha afinado mucho el programa que interpreta las señales, para decodificar información muy precisa sobre "'"posición, velocidad, actividad muscular del brazo y fuerza en el agarre de la mano'"', explica Carmena. Parte del avance se debe a que el número de electrodos ha aumentado -a un animal se le implantaron 96, y al otro, 320-, con lo que registran la señal eléctrica de unas 250 neuronas."

\section{A.10 Cultura Tecnológica Práctica Extrínseca}

ID 234 [P2:18 y 19] «La tecnología está sobrepasando la capacidad de las autoridades para legislar sobre estos nuevos instrumentos», afirma Steven Aftergood, que recalca que el VeriChip se ha colado aprovechando un vacío legal existente.

Mientras los gobiernos se lo piensan, la carrera biónica avanza rápido. Kevin Warwick, profesor de cibernética de la Universidad británica de Reading, ya ha recibido el primer implante electrónico, que conecta su brazo a un ordenador personal, que archivará la actividad de su sistema nervioso y también le enviará señales y estímulos.

ID 4720 [P29:08] NAVEGADOR SONORO. El negocio, ésa es la clave. Gigantes como IBM o Microsoft llevan años investigando sobre formas alternativas de interacción entre el hombre y la máquina. Con la vista puesta en las personas con alguna minusvalía, han llegado a comercializar productos para el reconocimiento de voz o la navegación sonora. Pero sus prestaciones son limitadas. Otro ejemplo, el W3C, organismo que gobierna Internet, lanzó en 1999 las especificaciones que debían cumplir los navegadores por voz. Hace dos semanas, aún andaban con recomendaciones sobre la gramática.

ID 4778 [P49:13] El éxito del innovador proyecto [prótesis intraocular] dependerá en buena medida de la colaboración de las nueve instituciones que se han implicado en el mismo. Además de las ya citadas, en el programa trabajan varios laboratorios del departamento de Energía de EEUU, que ha aportado seis millones de dólares a la investigación, dos compañías privadas californianas y otras dos universidades más estadounidenses.

ID 5128 [P51:19] El crecimiento del sector ha sido exponencial. En 1995, apenas 7.000 mayores disponían del servicio [teleasistencia]. Este año, las plazas públicas se han incrementado un $17 \%$. Sin embargo, salvo las excepciones de Madrid y otras regiones como Navarra, Andalucía, 
Castilla-La Mancha y Castilla-León, que se reparten más del 60\% de los usuarios, hay ayuntamientos que aún no lo han incluido en su catálogo de prestaciones. A nivel global, sólo el 2,05\% de los mayores de 65 años está cubierto por este servicio, una cifra «claramente insuficiente» a juicio de los expertos. La pasada semana, la Organización de Consumidores y Usuarios (OCU) denunciaba la escasez de recursos disponibles para los enfermos de demencia tipo Alzheimer. Solo un $2 \%$ recibe teleasistencia.

ID 769 [P53:04] "En el futuro, los principales beneficiarios serán los discapacitados físicos", explica con cautela José del Rocío Millán, que acaba de recibir el Premio Salvà i Campillo 2001, de la asociación catalana de Ingenieros de Telecomunicaciones, al proyecto de investigación más destacado. El objetivo del proyecto ABI (Adaptive Brain Interface, interfaz cerebral adaptable), promovido por la Comisión Europea, es demostrar que existe una tecnología que permitirá a las personas hacer mejor sus tareas.

ID 3947 [P71:16] "Por la tarde le tocó el turno a la ONCE, que colaborará con Microsoft en el desarrollo de tecnologías accesibles para los discapacitados. El empresario admitió entonces algunas preguntas de la prensa. Confesó que Microsoft tiene "'"grandes competidores"'", entre los que mencionó a IBM, Google, Nokia, Sony y al software libre. Aseguró, en todo caso, que su sueño sigue siendo "'thacer un software cada vez mejor"'"'."

ID 4333 [P76:11] Creo que la incertidumbre legal sobre qué se puede hacer en una tecnología cuando llega a una alta cuota de mercado es un problema para la industria y no sólo para Microsoft. Piense en la expansión de los teléfonos móviles, que también tienen su sistema operativo, en el universo del multimedia. Me temo que el problema del supuesto ataque a la competencia aparece sólo cuando una tecnología consigue un uso mayoritario. Media Player, en versiones más sencillas, existe desde mediados de los años noventa y nuestros competidores no han reaccionado hasta ahora.

ID 4453 [P79:11] Sin duda, es un buen negocio para los fabricantes, pero no son los únicos responsables. Entre la abundante legislación española sobre telecomunicaciones, en uno de sus decretos se exige que la venta del aparato tecnológico incluya los accesorios esenciales, como la batería y el cargador, sin los que el artilugio en cuestión no funciona.

ID 5183 [P82:10 y 11] Paralelamente, entre 1998 y 2002 se llevó a cabo otro programa comunitario para la investigación y el desarrollo tecnológico en enfermedades raras y medicamentos huérfanos. Dentro del apartado de calidad de vida se financiaron 14 proyectos, con un coste de 16,8 millones de euros. 
Francia es el país europeo que más sensibilidad ha mostrado ante este tema, y fue el que fomentó la creación y desarrollo de la Organización Europea para Enfermedades Raras (Eurordis, según las siglas en inglés), un movimiento asociativo de gran presencia y alta presión en las instituciones de la UE.

\section{A. 11 Cultura Tecnológica Valorativa Intrínseca}

ID 5218 [P16:20] Esta compleja corona de metal se fija con tornillos al cráneo y es la base de todas las acciones posteriores. Gracias a ella se pueden introducir hasta el lugar elegido, y con una precisión milimétrica, varillas de metal de diámetro muy pequeño que permitan colocar electrodos, sustancias específicas e incluso células madre.

ID 2967 [P90:05] "Los robots convencionales que andan sobre dos patas tienen que tener actuadores o motores en cada articulación y por ello su consumo es alto, explicó Ruina. El caso de referencia es el bípedo japonés Asimo, un robot convencional en este sentido. El ejemplar de Cornell es 10 veces más eficiente en consumo de energía por unidad de peso y distancia recorrida. "'"El robot de Cornell utiliza la energía sólo para avanzar"'", dijo el investigador. '"'En otros robots los motores están luchando contra sí mismos'"'. Ruina y Collins destacaron que su trabajo va a permitir conocer mejor la biomecánica de la locomoción humana, lo que debe tener aplicaciones médicas en rehabilitación y en el desarrollo de mejores prótesis."

\section{A.12 Cultura Tecnológica Valorativa Extrínseca}

ID 5119 [P4:03] Imitar una maquinaria tan compleja como el cuerpo humano no es, ni mucho menos, sencillo. Expertos de los centros más prestigiosos del mundo han hecho un repaso del estado actual de los trabajos en el campo de la biónica en un especial publicado en el último número de 'Science'.

ID 510 [P15:09] Para sus creadores, el sistema es «flexible y su funcionamiento natural», y tiene en cuenta además los avances que el propio usuario va realizando. "Su experiencia le permite adquirir nuevas capacidades mentales», destaca Millán.

ID 2559 [P19:18] Este es un fascinante y ambicioso campo de estudio [robótica] que todavía está dando sus primeros pasos, pero que ya ha logrado algunos resultados espectaculares en experimentos preliminares con animales y personas. 
ID 4453 [P79:16] "La Asociación Europea de Consumidores para la Normalización (ANEC) considera que "''desde el punto de vista del consumidor, un estándar para los cargadores y clavijas de los aparatos electrónicos de las diferentes marcas facilitaría su uso. Un patrón común que también debería fomentar el diseño ergonómico"'", asegura Chiara Giovannini, responsable de sociedad de la información de la ANEC."

ID 2942 [P89:02] En definitiva se trata del sorprendente mundo de las comunicaciones e interacciones entre humanos y ordenadores, o si se quiere entre la inteligencia natural y la artificial, cuyas aplicaciones se centran fundamentalmente en proporcionar un cierto grado de independencia a las personas con distintos grados de parálisis. Sin embargo, muchos ven en este campo posibilidades que trascienden ampliamente la medicina para adentrarse en terrenos propios de la ciencia-ficción. 


\section{B. POSITIVOS}

\section{B. 1 Accesibilidad}

ID 951 (P58:1) El proyecto de fin de carrera de César Mauri, de la URV, propone una solución que permita el acceso a la informática a personas con discapacidades en las extremidades.

ID 951 (P58:2) El objetivo de este proyecto de fin de carrera es demostrar que es posible proporcionar una herramienta con la cual personas con discapacidades en las extremidades (problemas de movilidad en los brazos o con amputaciones) puedan acceder más fácilmente a los ordenadores y la red. En otros casos, también permite liberar las manos para realizar otras tareas.

ID 3947 (P71:16) "Por la tarde le tocó el turno a la ONCE, que colaborará con Microsoft en el desarrollo de tecnologías accesibles para los discapacitados. El empresario admitió entonces algunas preguntas de la prensa. Confesó que Microsoft tiene "'"grandes competidores"'", entre los que mencionó a IBM, Google, Nokia, Sony y al software libre. Aseguró, en todo caso, que su sueño sigue siendo "'hacer un software cada vez mejor"'"."

ID 5171 (P80:1) Ciertamente, en la actualidad, tanto la telefonía móvil como Internet nos ofrecen un sinfín de posibilidades. Si además tenemos en cuenta su accesibilidad -es emocionante ver a los adultos cómo se introducen en eso del correo electrónico en cibertecas públicas-, podremos decir que estamos ante un elemento democratizador de la sociedad.

\section{B.2 Adecuación}

ID 1809 (P67:03) Los audífonos de última generación son casi todo menos un mero amplificador del sonido. En minúsculas carcasas de apenas un centímetro cúbico de volumen es posible encontrar dos micrófonos multidireccionales, un amplificador capaz de alcanzar 140 decibelios, un altavoz y un paquete de por lo menos cuatro chips de silicio que almacenan medio megabit de memoria que da cabida a programas informáticos que se ajustan automáticamente a distintos escenarios acústicos. 
ID 1809 (P67:04) Por el momento, la personalización extrema no es posible, pero los audífonos digitales disponibles empiezan a acercarse a este objetivo. La idea que planea en la mente de los grandes fabricantes del sector no es sólo disponer de un instrumento capaz de reproducir exactamente los sonidos de un entorno, sino discriminar entre el llamado sonido útil y el ruido, ofrecer soluciones para distintos escenarios y, sobre todo, personalizar esas soluciones de acuerdo a las preferencias, hábitos - necesidades de cada individuo. En paralelo, alguno de los últimos modelos tratan de conjugar el audífono digital con otras tecnologías como la telefonía móvil o la transmisión por ondas de radio.

\section{B.3 Apoyo}

ID 121 (P1: 07 Y 09) Se espera también poder aplicar esta tecnología para restaurar cierto control de movimientos en pacientes con parálisis o lesiones de la médula espinal. (...) Serruya añadió que el grupo de científicos ha creado una compañía para desarrollar un aparato médico que ayude a personas con parálisis.

ID 510 (P15:02) La relación entre el cerebro humano y la inteligencia artificial se estrecha cada vez más, y va arrojando por el camino algunas preguntas fundamentales sobre los mecanismos de la razón. Pero también podría mejorar nuestra vida cotidiana. Por ejemplo, si un robot es capaz de entender órdenes mentales, también podría ayudar a personas discapacitadas a moverse con mayor facilidad.

ID 3537 (P36:01) Cirujanos de Londres trasplantarán células nasales para regenerar nervios seccionados. La revolucionaria técnica podría ayudar a andar de nuevo a personas afectadas de parálisis

\section{B.4 Avance}

ID 791 (P54:11) Quienes están a favor ven enormes beneficios en la clonación. Como salvar especies en vías de extinción, fortalecer las razas, crear gatos que no produzcan alergia, mascotas diseñadas especialmente para ayudar a los impedidos, a los ciegos o a la policía; amén del consuelo que puede representar para los amos que pierden a sus acompañantes.

ID 5119 (P4:14) Dejando a un lado lo que, por el momento, no son más que profecías, la ingeniería biomédica ha hecho algunas aportaciones que se encuentran ya en el mercado de unos cuantos países. Un ejemplo es un dispositivo para el control del temblor en los enfermos de Parkinson. 
ID 5119 (P4: 17) Capturar las señales exteriores para conducirlas hasta la región neuronal adecuada es la estrategia que se sigue en algunos casos de sordera profunda. Los implantes cocleares supusieron una auténtica revolución para aquellos pacientes con pérdida completa de la audición que conservaban el nervio auditivo intacto.

ID 3537 (P36:02) A principios del próximo año, unos cirujanos intentarán reparar los nervios seccionados de jóvenes que sufrieron accidentes de moto. Será el primer ensayo de una tecnología simple, pero potencialmente revolucionaria, que algún día podría permitir que personas afectadas de parálisis vuelvan a andar.

ID 3805 (P41:09) No es éste el único avance conocido ayer en el ámbito de la visión. El británico Gislin Dagnalle acaba de presentar un ojo biónico, que asegura que permitirá ver a los ciegos, al menos hasta poder reconocer una cara, según informa la BBC. Se trata de un chip que se coloca detrás del ojo y está conectado a una minicámara de vídeo insertada en los cristales de las gafas. Las imágenes captadas son enviadas al chip, que las traduce en impulsos eléctricos para que las pueda interpretar el cerebro.

ID 1809 (P67:03) Los audífonos de última generación son casi todo menos un mero amplificador del sonido. En minúsculas carcasas de apenas un centímetro cúbico de volumen es posible encontrar dos micrófonos multidireccionales, un amplificador capaz de alcanzar 140 decibelios, un altavoz y un paquete de por lo menos cuatro chips de silicio que almacenan medio megabit de memoria que da cabida a programas informáticos que se ajustan automáticamente a distintos escenarios acústicos. Y por lo que parece, esto no es el final, sino un simple tránsito hacia la promesa de aparatos extraordinariamente individualizados gracias a la miniaturización y a la integración de los últimos logros de la tecnología digital.

\section{B.5 Beneficio}

ID 769 (P53:4) "En el futuro, los principales beneficiarios serán los discapacitados físicos, explica con cautela José del Rocío Millán, que acaba de recibir el Premio Salvà i Campillo 2001, de la asociación catalana de Ingenieros de Telecomunicaciones, al proyecto de investigación más destacado. El objetivo del proyecto ABI (Adaptive Brain Interface, interfaz cerebral adaptable), promovido por la Comisión Europea, es demostrar que existe una tecnología que permitirá a las personas hacer mejor sus tareas.

ID 791 (P54:11) "Quienes están a favor ven enormes beneficios en la clonación. Como salvar especies en vías de extinción, fortalecer las razas, 
crear gatos que no produzcan alergia, mascotas diseñadas especialmente para ayudar a los impedidos, a los ciegos o a la policía; amén del consuelo que puede representar para los amos que pierden a sus acompañantes.

\section{B.6 Calidad}

ID 3097 (P93:01) Pilar Vázquez, madre de Alicia, una niña de ocho años, es rotunda: su objetivo es conseguir la "'máxima normalización"'" de su hija. Su deseo es que participe "'"en el mundo en que vive y haga una carrera de acuerdo con sus aptitudes, a pesar de de ser sorda"'". Alicia, la hija de Pilar Vázquez, estudia 3ำ de Primaria en el colegio madrileño Tres Olivos y lleva un implante bilateral, es decir, uno en cada oído. "'Ha sido una decisión familiar. He llegado a la conclusión de que si ya con uno tenía una buena calidad, con dos iba a ser mejor. Desde julio, Alicia oye con los dos, y para ella es mucho más cómodo. Un día se le acabó la pila del primero y dijo: 'Oigo más bajo'. No es una cuestión de volumen. Lo que sucede es que con los dos localiza mejor los sonidos'"', sigue su madre."

\section{B.7 Calidad de Vida}

ID 4746 (P30:22) "Tras someterse a la cifoplastia por una dolorosa fractura vertebral, los pacientes regresaron rápidamente a un nivel de actividad mayor y más independiente [que antes de la operación], lo que les llevó a una mayor calidad de vida», concluyen los autores.

ID 4746 (P30:41) Luciana no toma fármacos contra la enfermedad, pero sí ha recibido otras 'recetas' para esta patología ósea, como ejercicio (caminar, natación...), una alimentación en la que no falten los lácteos y revisiones médicas dos veces al año. Además, la cifoplastia le ha permitido recuperar parte de su vida normal: «Hoy en día puedo tender la ropa, agacharme o coger a mi nieta. Lo que antes no podía hacer».

ID 5171 (P80:02) Pero si por un motivo me ha interesado el reportaje de la revista es por todo lo que las nuevas tecnologías mejoran la calidad de vida de las personas con alguna discapacidad.

ID 2902 (P86:01) "Uno de los hitos más relevantes de las últimas décadas en el campo de la otorrinolaringología ha sido el empleo de los implantes cocleares en el tratamiento de la sordera. Esta técnica tiene la potencialidad de cambiar la calidad de vida de las personas que sufren una sordera. Y con los cambios, en ocasiones surge el conflicto. Ciertos líderes de la comunidad sorda, como recientemente hemos leído en su periódico, señalan que la sordera no es una enfermedad, y por lo tanto operar a un niño "'"sano"'! para colocarle un implante coclear no es ético. 
Además, entre otras cuestiones, afirma que los beneficios lingüísticos obtenidos son muy modestos."

\section{B.8 Cambio}

ID 3096 (P92:01) Los sordos viven un encendido debate. Para muchos la sordera forma parte de su identidad y no es una estricta discapacidad. Al mismo tiempo, un nutrido grupo de niños y jóvenes oyen y hablan ya como si no lo fueran, gracias al implante coclear. Este dispositivo (un electrodo instalado en el oído interno y un aparato externo con micrófono y procesador electrónico) ha revolucionado su vida.

\section{B.9 Comunicación}

ID 510 [P15:18] Este método, aún en fase experimental, permitirá que personas discapacitadas del cuello para abajo puedan enviar cartas y mensajes. Al igual que para moverse con la silla de ruedas, no son necesarios implantes quirúrgicos en el cerebro. Basta la actividad eléctrica que detecta el gorro de electrodos.

ID 592 [P18:06] Con un encefalograma y sin intervención quirúrgica de por medio, investigadores de la Universidad de Tubingen, en Alemania, crearon un sistema para que los discapacitados puedan escribir mensajes en una pantalla de ordenador. Sus impulsos neuronales mueven un cursor y seleccionan las letras de un teclado virtual.

ID 4598 [P52:09] Algunos días Uribe llega a pasar 12 horas frente al monitor. 'El ordenador es mi vida'. Por medio del PC mantiene charlas sobre Bruce Springsteen, su ídolo. 'Stone Pony London, un foro de Springsteen, es mi devoción. Allí he hecho un montón de amigos. Desde que dispongo de ADSL, puedo intercambiar ficheros musicales con otros amigos'.

ID 905 [P57:03] Durante el resto de su vida, el ordenador de su silla de ruedas ha sido su única forma de comunicarse con el mundo. Su cerebro, sin embargo, sigue sin tener el más mínimo problema para comunicarse con el universo. Hawking es uno de los físicos teóricos contemporáneos más brillantes, y ha construido la mayor parte de su trabajo elevándose sobre los hombros de dos gigantes: Albert Einstein y Richard Feynman.

ID 3098 [P94:04] "Lucía Sánchez no se anda con rodeos: "'Ser sorda para mí es una faena, por no decir una palabrota que aquí estaría bien utilizada. Dentro de eso, hay cosas positivas que vas descubriendo por el camino. Estoy contenta con el implante, porque quiero oír y mejorar mi comunicación y estoy a gusto dentro de la comunidad sorda. Además de un nombre, tengo un signo'"'. 


\section{B.10 Confianza}

ID 4892 [P12:02] Esta es la conclusión de una investigación estadounidense que reclama una mayor precaución a la hora de sustituir las tradicionales radiografías por el uso de las modernas técnicas de imagen en el diagnóstico de las molestias lumbares, un fenómeno que también se está produciendo en España. El motivo es que, según explican los autores del trabajo, tanto al médico como al paciente les ofrece mayor confianza el resultado de la exploración realizada con resonancia magnética (RM).

\section{B.11 Efectividad}

ID 4385 [P78:05] También puede resultar efectivo para tratar otras enfermedades, principalmente la ceguera en las personas con diabetes, pero también se va a estudiar su uso en terapias contra la obesidad, fracturas óseas, algunos problemas dermatológicos y ciertas enfermedades neurodegenerativas, como el alzheimer o la esclerosis.

\section{B.12 Eficiencia}

ID 2784 [P24:06] El ojo artificial consiste en una cámara digital insertada en la lente de unas discretas gafas de sol de las que sale un cable que conecta con un pequeño ordenador que se esconde en el cinturón del paciente. La imagen procesada por el ordenador transmite las señales que estimulan a la corteza cerebral implicada en la visión directamente, sin tener que utilizar el nervio óptico que se supone dañado. Los pacientes ven una serie de puntos luminosos que conforman, a grandes rasgos, una imagen de la realidad. Gracias a ello consiguen una amplia independencia en cuanto a movilidad, pero no pueden llegar a realizar tareas de mayor precisión como leer. El invento se usa hoy con normalidad y funciona con personas que han perdido la vista de manera traumática y a las que no les es posible realizar un trasplante de retina.

ID 2967 [P90:05] "Los robots convencionales que andan sobre dos patas tienen que tener actuadores o motores en cada articulación y por ello su consumo es alto, explicó Ruina. El caso de referencia es el bípedo japonés Asimo, un robot convencional en este sentido. El ejemplar de Cornell es 10 veces más eficiente en consumo de energía por unidad de peso y distancia recorrida. "'El robot de Cornell utiliza la energía sólo para avanzar"'", dijo el investigador. "'"En otros robots los motores están luchando contra sí mismos'"'. Ruina y Collins destacaron que su trabajo va a permitir conocer mejor la biomecánica de la locomoción humana, lo 
que debe tener aplicaciones médicas en rehabilitación y en el desarrollo de mejores prótesis."

\section{B.13 Facilitar}

ID 590 [P17:05] Estos descubrimientos facilitarían la rehabilitación de personas con la médula espinal dañada, ya que se podrían implantar electrodos en diferentes grupos de neuronas para estimular la capacidad motora: "Si distintas células pueden realizar las mismas funciones, los cirujanos tendrán más flexibilidad para decidir cómo y cuando introducen electrodos u otros estimuladores en el cerebro», asegura el informe, al que se puede acceder gratuitamente en Internet.

ID 4989 [P33:01] No tiene cámara de fotos, ni millones de colores, ni funciones avanzadas de agenda electrónica. Por no tener, no tiene ni pantalla. El Owasys $22 \mathrm{C}$ es un teléfono móvil muy diferente al resto. No está pensado para la mayoría de los usuarios, sino para una pequeña minoría que, hasta ahora, tenía muchos problemas a la hora de utilizar esta tecnología. Es el primer teléfono de Europa pensado para facilitar la comunicación de los invidentes.

ID 4989 [P33:04] Otros detalles, como las teclas en relieve o el altavoz de alta potencia, facilitarán el manejo a los usuarios. Se comercializará en los puntos de venta de Telefónica Móviles y en las oficinas de la ONCE y su precio será de 400 euros.

ID 4453 [P79:03] Si la tecnología facilita nuestras vidas, ¿̇por qué en las casas hay más cargadores que teléfonos? ¿De qué sirve un móvil de 100 gramos si el cargador pesa medio kilo? ¿ Cómo es posible que ni siquiera un mismo fabricante tenga el mismo cargador para todos sus modelos? ¿Hasta cuándo, en definitiva, la industria desatenderá las lógicas del consumidor?

ID 3097 [P93:03] "Javi, de siete años, acude al colegio Sagrada Familia de Valencia y también lleva dos implantes. Su madre, Luisa López, cargo directivo de FIAPAS en Valencia, dice que ahora oye mejor cuando se le llama y vuelve la cabeza hacia donde viene el sonido. "'Con un solo implante se puede desarrollar el lenguaje, pero con dos el esfuerzo es menor"'", agrega."

\section{B.14 Fiabilidad}

ID 3901 [P68:11] En este momento hay en España más de 3.500 implantados y 34 centros de la sanidad pública que efectúan esta operación. El número de operaciones de implante coclear es de 500 
anuales, y con listas de espera en diversos lugares. Si fuera poco fiable no estaríamos en esta situación, o todos estamos locos.

\section{B.15 Inteligencia}

ID 3701 [P39:17] Además de haber caminado sobre nuestro satélite, este pionero de la exploración espacial ha sobrevivido a 66 combates aéreos en la guerra de Corea y ha superado enfermedades como el alcoholismo, la depresión y la sordera aguda. De hecho, su reciente paso por Europa se debe a la promoción del Savia, un audífono inteligente -capaz de discriminar los ruidos no deseados- desarrollado por la compañía Phonak y que él mismo utiliza.

ID 3851 [P44:06] El más inteligente de los tres robots es el que ha sido desarrollado por el MIT. Bautizado oficialmente como Toddler (bebé, en inglés), no sólo es casi humano, sino que además es capaz de aprender a moverse. En menos de 20 minutos, el tiempo que tarda en dar unos 600 pasos, el androide ya es capaz de imitar a la perfección la forma de andar de los hombres. Además, reconoce el tipo de superficie por la que se desplaza y se adapta a ella.

ID 2942 [89:06] "Para lograr alcanzar un lenguaje común es necesario un periodo de aprendizaje, los científicos piden a los futuros amos de la máquina que ejecuten mentalmente ciertas acciones. Así recogen la huella eléctrica de sus cerebros y posteriormente hacen que el ordenador asocie cada una de ellas a un movimiento o tarea precisa. "'Los tiempos de aprendizaje que hemos necesitado hasta el momento son cortos. Unos cinco días trabajando sólo una hora y media cada día'"', explica Millán. Y desde luego cuanto más convivencia entre el humano y la máquina más se van perfeccionando los canales de comunicación en ambos sentidos. "'"Es como un músculo mental. Cuanto más lo ejercitas, más fuerte se vuelve y más sensible"'". A esto se añade que "'"el robot tiene una cierta inteligencia para valorar los obstáculos que se encuentra en el camino sin necesidad de que la persona le esté dando permanentemente

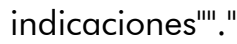




\section{B. 16 Independencia}

ID 510 [P15:03] Esta es la tesis de un grupo de científicos suizos y españoles, cuyo objetivo es crear una silla de ruedas guiada por ondas cerebrales. Con ella, los parapléjicos con la movilidad muy limitada podrían desenvolverse por sí mismos en entornos domésticos.

ID 590 [P17:03] En un futuro próximo, las personas parapléjicas podrán recuperar al menos parte de su movilidad gracias a prótesis robóticas que controlarán con los impulsos de su propio cerebro. Esto es lo que se deduce de las pioneras investigaciones que ha llevado a cabo un científico español en la Universidad de Duke (EEUU).

ID 2559 [P19:17] En los últimos años, la idea de fusionar la biología con la robótica se ha convertido en una nueva utopía médica. Muchos investigadores están convencidos de que, en el futuro, las personas parapléjicas podrán recuperar al menos parte de su movilidad gracias a sofisticadas prótesis robóticas y sillas de ruedas controladas por los impulsos neuronales del cerebro humano.

ID 2784 [P24:06] El ojo artificial consiste en una cámara digital insertada en la lente de unas discretas gafas de sol de las que sale un cable que conecta con un pequeño ordenador que se esconde en el cinturón del paciente. La imagen procesada por el ordenador transmite las señales que estimulan a la corteza cerebral implicada en la visión directamente, sin tener que utilizar el nervio óptico que se supone dañado. Los pacientes ven una serie de puntos luminosos que conforman, a grandes rasgos, una imagen de la realidad. Gracias a ello consiguen una amplia independencia en cuanto a movilidad, pero no pueden llegar a realizar tareas de mayor precisión como leer. El invento se usa hoy con normalidad y funciona con personas que han perdido la vista de manera traumática y a las que no les es posible realizar un trasplante de retina.

ID 4746 [P30:22] «Tras someterse a la cifoplastia por una dolorosa fractura vertebral, los pacientes regresaron rápidamente a un nivel de actividad mayor y más independiente [que antes de la operación], lo que les llevó a una mayor calidad de vida», concluyen los autores.

ID 3815 [P42:04] Después de una operación en el Hospital New England Sinai en Massachusetts, Nagle se ha convertido en el primer paciente que participa en un ensayo controvertido sobre implantes cerebrales que podrían ayudar a personas discapacitadas a ser más independientes, mediante la estimulación de sus ondas cerebrales.

ID 2942 [P89:02] En definitiva se trata del sorprendente mundo de las comunicaciones e interacciones entre humanos y ordenadores, o si se quiere entre la inteligencia natural y la artificial, cuyas aplicaciones se 
centran fundamentalmente en proporcionar un cierto grado de independencia a las personas con distintos grados de parálisis. Sin embargo, muchos ven en este campo posibilidades que trascienden ampliamente la medicina para adentrarse en terrenos propios de la ciencia-ficción.

\section{B.17 Innovación}

ID 4778 [P49:13] El éxito del innovador proyecto [prótesis intraocular] dependerá en buena medida de la colaboración de las nueve instituciones que se han implicado en el mismo. Además de las ya citadas, en el programa trabajan varios laboratorios del departamento de Energía de EEUU, que ha aportado seis millones de dólares a la investigación, dos compañías privadas californianas y otras dos universidades más estadounidenses.

\section{B. 18 Mejora}

ID 234 [P2:19,20] Mientras los gobiernos se lo piensan, la carrera biónica avanza rápido. Kevin Warwick, profesor de cibernética de la Universidad británica de Reading, ya ha recibido el primer implante electrónico, que conecta su brazo a un ordenador personal, que archivará la actividad de su sistema nervioso y también le enviará señales y estímulos.

Este experimento es el primer paso para remediar parálisis corporales parciales, en brazos y manos.

ID 5218 [P16:15] Por eso, los especialistas pretenden alcanzar con electrodos los ganglios de la base del cerebro, concretamente los núcleos subtalámicos (se encuentran por debajo del tálamo -una estructura fundamental del sistema nervioso-). Si se consigue estimular con débiles corrientes eléctricas esos núcleos se logra frenar las señales anormales de los mismos. Los síntomas entonces pueden mejorar de una forma marcada.

ID 590 [P17:06] Esta técnica dio por primera vez resultado el año pasado en EEUU, cuando un hombre con la médula espinal dañada volvió a caminar tras recibir un tratamiento con electrodos. Los estudios de Carmena sugieren que varios grupos de neuronas, situados en la corteza frontal y parietal, tienen la capacidad de controlar un brazo robótico. Esto implica que incluso en algunos pacientes con daños cerebrales podría encontrarse una zona sana con la que llevar a cabo la rehabilitación.

ID 3815 [P42:09] En las pruebas más recientes, realizadas a principios de este año, Nagle pudo usar el pensamiento para abrir y cerrar una prótesis 
artificial de mano y mover un brazo robótico para coger caramelos de la mano de una persona y dejarlos en otra. También ha mejorado sus habilidades en los juegos de ordenador practicando con el Pong.

ID 4778 [P49:01] Una prótesis intraocular experimental que se implanta en el fondo de la retina ha permitido recuperar temporalmente parte de la visión a seis pacientes que la habían perdido debido a la retinosis pigmentaria, una enfermedad degenerativa que daña las células que permiten que la luz que capta el ojo se traduzca en imágenes reconocibles. El dispositivo se implantó quirúrgicamente en un único ojo, el que peor estado presentaba, y gracias a él los participantes en el ensayo fueron capaces de detectar cuándo se enciende y se apaga la luz, de identificar objetos de su entorno y de percibir el movimiento.

\section{B. 19 Natural}

ID 510 [P15:09] Para sus creadores, el sistema es «flexible y su funcionamiento natural», y tiene en cuenta además los avances que el propio usuario va realizando. «Su experiencia le permite adquirir nuevas capacidades mentales», destaca Millán.

ID 4314 [P75:14] R. Cuando se trata de prestar ayuda en un entorno doméstico, la apariencia amigable de una máquina facilita mucho la interacción y su aceptación. A una persona mayor o con discapacidades físicas le resulta más fácil dar órdenes a alguien que le recuerda a un asistente que no a una máquina impersonalizada.

\section{B.20 Necesario}

ID 5128 [P51:20] El Plan Gerontológico del año 2000 marcaba como objetivo un índice del $12 \%$ de población 'teleatendida'. El anteproyecto de Ley de Dependencia, actualmente en discusión, prevé potenciar este dispositivo asistencial con la creación de 800.000 nuevas plazas en los próximos años. "Como mínimo deberían tenerlo todos los que viven solos y los que residen con su familia pero son semiválidos [tienen alguna discapacidad]», dice Martínez Gómez. «Sólo en Reino Unido hay más de un millón de usuarios», compara Inmaculada Romero.

\section{B.21 Oportunidad}

ID 2559 [P19:12] Entre las posibilidades que abre esta nueva tecnología, el profesor Montemagno vislumbra la que se le ofrece a las personas que tienen dañados los nervios encargados de estimular el diafragma y, así, permitir el proceso de la respiración. 
ID 3805 [P41:09] No es éste el único avance conocido ayer en el ámbito de la visión. El británico Gislin Dagnalle acaba de presentar un ojo biónico, que asegura que permitirá ver a los ciegos, al menos hasta poder reconocer una cara, según informa la BBC. Se trata de un chip que se coloca detrás del ojo y está conectado a una minicámara de vídeo insertada en los cristales de las gafas. Las imágenes captadas son enviadas al chip, que las traduce en impulsos eléctricos para que las pueda interpretar el cerebro.

ID 3815 [P42:10] Donoghue espera que el implante, llamado BrainGate (puerta cerebral), permitirá a los parapléiicos recuperar el uso de sus piernas. «Si podemos encontrar un modo de enganchar esto a sus propios músculos, podrá abrir y cerrar sus manos y mover sus brazos», asegura. «Estamos muy animados con Matthew, pero somos cautos. Sólo es una persona. Hay que llegar más lejos, pero estamos totalmente en el camino».

ID 3816 [P43:05] Una de las últimas creaciones ha sido la de un robot que tiene su fuente de energía en un músculo animal, un híbrido entre tecnología y biología que tendría múltiples posibilidades para los paralíticos.

\section{B.22 Precisión}

ID 1809 [P67:04] Por el momento, la personalización extrema no es posible, pero los audífonos digitales disponibles empiezan a acercarse a este objetivo. La idea que planea en la mente de los grandes fabricantes del sector no es sólo disponer de un instrumento capaz de reproducir exactamente los sonidos de un entorno, sino discriminar entre el llamado sonido útil y el ruido, ofrecer soluciones para distintos escenarios $y$, sobre todo, personalizar esas soluciones de acuerdo a las preferencias, hábitos - necesidades de cada individuo. En paralelo, alguno de los últimos modelos tratan de conjugar el audífono digital con otras tecnologías como la telefonía móvil o la transmisión por ondas de radio.

ID 1809 [P67:11] El futuro, señala Chapero, pasa sobre todo por la capacidad de incrementar el volumen de memoria informática insertado en los audífonos. Esta mayor disponibilidad, en la que se encuentra trabajando toda la industria del sector, debería permitir dotar a estos instrumentos de mayor número de programas $y$, sobre todo, de la posibilidad de autoaprendizaje. Es decir, dotar al audífono de capacidad para autorregularse en función del ambiente y del comportamiento individual. 


\section{B.23 Solución}

ID 592 [P18:02] El control de robots mediante impulsos cerebrales está experimentando un rápido desarrollo en los últimos años. Esta tecnología se presenta como una futura solución para los parapléjicos, que podrían usar distintos ingenios para desplazarse, agarrar objetos o escribir sobre una pantalla de ordenador.

ID 2559 [P19:03] El musculobot, como le han denominado sus creadores, podría llegar a solucionar el problema de las personas paralíticas que precisan de un ventilador para respirar, como el caso del actor Christopher Reeve, o reparar los agujeros que provocan los impactos de minúsculos meteoritos en las naves espaciales. En todo caso, se ha abierto la puerta a un mundo de híbridos de la tecnología y la biología que hasta ahora formaban parte de la ciencia ficción.

ID 951[P58:01] El proyecto de fin de carrera de César Mauri, de la URV, propone una solución que permita el acceso a la informática a personas con discapacidades en las extremidades.

\section{B.24 Útil}

ID 121 [P1:01] Investigadores de la Universidad de Brown (EEUU) han desarrollado un sistema para registrar, interpretar y reconstruir la actividad del cerebro que controla el movimiento de las manos, y han demostrado que, sólo con el pensamiento, se puede mover un cursor en una pantalla de ordenador para que llegue a un punto de destino, algo que el futuro podría ser de gran utilidad para las personas que sufren parálisis.

\section{B.25 Ventaja}

ID 121 [P1:06] El nuevo trabajo es un paso adelante para conseguir que las personas con parálisis puedan mover un cursor valiéndose del pensamiento, lo que les permitirá manejar un ordenador, con todas las ventajas que proporciona la informática: correo electrónico, Internet, y otras funciones de movimiento de miembros robóticos.

ID 3096 [P92:01] Los sordos viven un encendido debate. Para muchos la sordera forma parte de su identidad y no es una estricta discapacidad. Al mismo tiempo, un nutrido grupo de niños y jóvenes oyen y hablan ya como si no lo fueran, gracias al implante coclear. Este dispositivo (un electrodo instalado en el oído interno y un aparato externo con micrófono y procesador electrónico) ha revolucionado su vida. Pero junto a sus 
ventajas, el uso de esta innovación ha suscitado la polémica en la comunidad sorda.

\section{B.26 Versatilidad}

ID 2942 [P89:04] "Las dificultades comienzan cuando el humano y la máquina tienen que encontrar un punto de entendimiento. Por este motivo los sistemas informáticos acaban siendo muy personales, es decir, programados para responder a las órdenes de una cabeza concreta. Cada tarea -ir a la derecha, subir o parar-activa zonas específicas de la corteza cerebral creando un dibujo eléctrico particular para cada acción. Pero "'"aunque existen mapas genéricos para todo el mundo, la actividad neuronal es fruto de las experiencias de cada individuo'"', explica Millán desde Suiza. De modo que para que el sistema funcione correctamente "'t'ienen que aprender tanto la máquina como el individuo"'"."

\section{NEGATIVOS}

\section{C.1 Dependencia}

ID 4122 [P73:06] Miguel Ángel Carrasco, director del hospital y vocal de la fundación (cuyo patronato encabeza el presidente regional), asegura que el centro mantiene ya contacto con los pacientes una vez que son dados de alta. Antes de eso, tanto ellos como sus familiares más directos son entrenados para que puedan desarrollar las actividades de la vida diaria, limitando al máximo su problema de dependencia, con gran frecuencia ligado a tener que utilizar una silla de ruedas.

ID 2929 [P88:03] Hoy Carles vuelve a hablar gracias a una técnica natural: la voz esofágica o erigmofónica. Tenía otras opciones, como la prótesis laríngea y el laringófono, pero ambas son artificiales, lo que implica la permanente dependencia de un aparato y la voz resultante es menos natural.

\section{C.2 Desigualdad}

ID 4453 [P79:17] "Esta organización pone de relieve que "'"el acceso a todos los productos y servicios es un derecho básico del consumidor, ya que existe discriminación si hay ciudadanos -personas mayores o con discapacidades- que no pueden usar los principales bienes [se refiere a aparatos tecnológicos] que se consumen hoy en día"'"." 


\section{C.3 Dificultad}

ID 4989 [P33:02] Los usuarios ciegos podían, hasta ahora, utilizar los teléfonos móviles habituales, pero con serias dificultades. No tenían acceso a los mensajes de texto o a la agenda. Incluso las funciones más simples, como consultar el estado de la batería o la hora, eran completamente imposibles para ellos.

ID 951 [P58:09] Este joven investigador considera que los sistemas de comunicación con el ordenador a través de la voz son, por ahora, poco prácticos para aplicaciones como pulsar iconos y enviar órdenes.

\section{C.4 Exclusión}

ID 4453 [P79:19] "La ANEC promueve la iniciativa Design for All (Diseño para Todos): "'"Las consecuencias de un mal diseño en los productos electrónicos pueden ser graves barreras para muchos ciudadanos. Una de ellas es el conector que debe insertarse en el teléfono móvil para que se recargue"'"', dice Giovannini."

\section{C.5 Inadecuado}

ID 3909 [P69:02] "La sordera no es un problema y los implantes cocleares no son buenos para los niños sordos"'". El psicólogo, lingüista y profesor estadounidense Harlan Lane defiende con pasión y convicción ideas que pueden generar asombro, en el mejor de los casos, o indignación, sobre todo si quienes las oyen son padres de un bebé sordo. Sin embargo, nadie discute su condición de experto, uno de los mayores, sobre la historia y la situación de la comunidad sorda. De hecho, Lane, invitado la pasada semana al Primer Congreso Internacional de Sordera celebrado en Bilbao, solicita que en la entrevista mantenida con EL PAÍS esté presente una persona sorda, -en este caso, el presidente de la Asociación de Sordos de Vizcaya, José Martín, uno de los organizadores-, que reacciona con una silente aprobación a las palabras de Lane traducidas a la lengua de signos."

ID 3909 [P69:12] "R. Creo que el niño sordo es perfectamente sano. Operar a un niño sano no es ético. Estoy trabajando en un laboratorio que se ocupa de los implantes cocleares, y yo estoy a favor de ellos y los apoyo para personas oyentes como nosotros. Pero la mayoría de los niños sordos nacen sordos y los beneficios lingüísticos de estos implantes son muy modestos. Es un error pensar: "'Ah, ahora realizas la cirugía y tienes un niño que oye"'t. Por ejemplo, pensemos en los enanos. Si los padres del enano son de una altura media, llevan al niño al cirujano ortopédico, le rompen las piernas, le colocan unos aparatos y poco a 
poco van separando los huesos a lo largo de años en un proceso doloroso $y$, al final, consiguen crecer apenas unos centímetros. En cambio, si los padres son enanos, piensan: "'"Eso es una locura, ¿̇qué tiene de malo ser enano?"'!. Es verdad que la sociedad no los mira bien, pero eso no tiene por qué pagarlo el niño. ¿̇Por qué no puede haber entonces personas sordas y oyentes?"

ID 4453 [P79:14] Tampoco es sólo un problema de despilfarro o incomodidad. Muchos de estos cargadores están tan mal diseñados que dificultan su uso por parte de las personas mayores y otras con defectos visuales, según destaca la organización de consumidores europeos ANEC.

\section{C.6 Ineficiencia}

ID 5119 [P4:10] Sin embargo, ningún material sintético desarrollado hasta el momento es capaz de responder de la misma forma que los tejidos vivos ante los cambios fisiológicos y bioquímicos del organismo. Buena parte de las prótesis construidas con estos elementos fallan pasados unos años, de modo que el paciente debe someterse a una nueva intervención para sustituir el implante.

\section{C.7 Inseguridad}

ID 3909 [P69:01] "En el mundo real, el implante coclear tiene muy poca fiabilidad"

ID 3998 [P72:05] "La situación es mucho más grave en los países en desarrollo, donde millones de personas sufren problemas crónicos o discapacidades que hubieran podido evitarse, ello si no mueren por culpa de errores médicos, transfusiones de sangre sin garantías, fármacos falsificados o de calidad inferior a la norma y, sobre todo, prácticas inseguras en condiciones de trabajo precarias'"'", dice Ebrahim Samba, director regional de la OMS para África. La OMS informa de que al menos un $50 \%$ del material médico no es de fiar, y un $77 \%$ de los casos de falsificación o mala calidad de los medicamentos se dan en países en desarrollo."

\section{C.8 Insuficiencia}

ID 4720 [P29:08] NAVEGADOR SONORO. El negocio, ésa es la clave. Gigantes como IBM ○ Microsoft llevan años investigando sobre formas alternativas de interacción entre el hombre y la máquina. Con la vista puesta en las personas con alguna minusvalía, han llegado a comercializar productos para el reconocimiento de voz o la navegación 
sonora. Pero sus prestaciones son limitadas. Otro ejemplo, el W3C, organismo que gobierna Internet, lanzó en 1999 las especificaciones que debían cumplir los navegadores por voz. Hace dos semanas, aún andaban con recomendaciones sobre la gramática.

\section{C.9 Molestia}

ID 5218 [P16:07] Se queja de que, al agacharse, le molesta un poco la pila que le han instalado en el vientre, pero puede volver a pintarse las uñas. Con pulso firme.

\section{C.10 Problema}

ID 4989 [P33:01] El Owasys 22C es un teléfono móvil muy diferente al resto. No está pensado para la mayoría de los usuarios, sino para una pequeña minoría que, hasta ahora, tenía muchos problemas a la hora de utilizar esta tecnología.

ID 4453 [79:13] Este problema va más allá de los teléfonos, un problema que afecta a los más de 37 millones de españoles que tienen un móvil. A esta montaña de aparatos redundantes se suman los de otros artilugios también portátiles, como los discman. En la mayoría de los casos se da la paradoja de que el instrumento auxiliar pesa más que el principal: el cargador más que el aparato.

\section{C.11 Riesgo}

ID 234 [P2:18] "La tecnología está sobrepasando la capacidad de las autoridades para legislar sobre estos nuevos instrumentos», afirma Steven Aftergood, que recalca que el VeriChip se ha colado aprovechando un vacío legal existente.

ID 4746 [P30:27] Pese a tratarse de una intervención segura, también tiene sus riesgos.

ID 4778 [P49:09] «Es sólo el primer paso de un largo viaje», afirma Humayun con cautela. El científico subraya que los estudios se dilatarán varios años ya que se trata de un dispositivo catalogado por la agencia estadounidense del medicamento, la FDA, como de clase III, es decir, de alto riesgo, debido a que el implante debe permanecer en el organismo durante el resto de la vida de su portador. 


\section{. DESEADOS}

\section{D.1 Accesibilidad}

ID 2806 [P25:06] Gates, no sólo tuvo tiempo para las pequeñas y medianas empresas, también para las grandes compañías, más experimentadas en la aplicación de estas herramientas. Acompañado de la consejera delegada de Microsoft lberia, Rosa María García, y, por supuesto, de Ana Patricia Botín, el magnate de la informática almorzó con otros empresarios y banqueros como Julio Linares, presidente de Telefónica de España, Francisco Román, consejero delegado de Vodafone España, Francisco González, presidente del BBVA o Miguel Carballeda, presidente de la ONCE. Con esta organización Microsoft firmó ayer un acuerdo de colaboración para garantizar el acceso a las nuevas tecnologías a los discapacitados.

\section{D.2 Brindar facilidades}

ID 4453 [P79:09] Es el primer paso hacia la simplificación de la vida moderna, algo que tenía que solucionar la tecnología y que bien por motivos legales o económicos no lo hace. Cada vez que alguien compra un teléfono móvil sale de la tienda también con medio kilo de cargador, que acumulará con los que ya tiene en casa.

\section{CÓDIGOS DE LOS DOCUMENTOS}

\begin{tabular}{ll} 
Documentos & Periódicos \\
\hline P1 a P6 & El Mundo 2002 \\
P7 a P18 & El Mundo 2003 \\
P19 a P33 & El Mundo 2004 \\
P34 a P51 & El Mundo 2005 \\
\hline P52 a P59 & El País 2002 \\
P60 a P67 & El País 2003 \\
P68 a P82 & El País 2004 \\
P83 a P101 & El País 2005 \\
\hline
\end{tabular}




\section{ÍNDICE DE TABLAS Y FIGURAS}

\section{TABLAS}

Tabla 1.1 Componentes de la Cultura Técnica (p.35)

Tabla 1.2 Contenidos Incorporados y No Incorporados (p.36)

Tabla 1.3 Cultura Técnica Incorporada y No Incorporada (p.39)

Tabla 2.1 Documentos legislativos relacionados con la discapacidad (p.44)

Tabla 2.2 Clasificación de las Ayudas Técnicas (p.49)

Tabla 2.3 Estadísticas de la Discapacidad en España en 1999 (p.54)

Tabla 2.4 Problemas que causan deficiencias (p.56)

Tabla 2.5 Consumo de ayudas técnicas (p.60)

Tabla 2.6 Ayudas técnicas utilizadas (p.61)

Tabla 2.7 Categorías de las fuentes consultadas para la recopilación de la producción científica española (p.71)

Tabla 2.8 Publicaciones referidas a discapacidad (p.73)

Tabla 2.9 Definición de las categorías temáticas de clasificación (p.75)

Tabla 2.10 Clasificación del tipo de institución (p.76)

Tabla 2.11 Evolución temporal de la producción (p.79)

Tabla 2.12 Tipo de producción (p.82)

Tabla 2.13 Revistas donde se publica sobre discapacidad y tecnología (p.83)

Tabla 2.14 Producción científica por temas (p.85)

Tabla 2.15 Tipo de instituciones (p.89)

Tabla 2.16 Producción científica por universidades (p.92)

Tabla 5.1 Comodines de búsqueda de ciencia y tecnología (p.115)

Tabla 5.2 Abreviaturas de los tipos de cultura científico-tecnológica (p. 116)

Tabla 5.3 Comodines de búsqueda de los aparatos tecnológicos y técnicas (p.117)

Tabla 5.4 Imágenes o valores reconocidos positivos (p.119)

Tabla 5.5 Imágenes o valores reconocidos negativos (p.120)

Tabla 5.6 Imágenes o valores deseados (p.120)

Tabla 5.7 Datos generales cuantitativos de la revista Minusval (p.121)

Tabla 5.8 Cultura científica en la revista Minusval (p.122)

Tabla 5.9 Cultura tecnológica en la revista Minusval (p.128)

Tabla 5.10 Cultura científico-tecnológica intrínseca en la revista Minusval (p.133)

Tabla 5.11 Cultura científico-tecnológica extrínseca en la revista Minusval (p.134)

Tabla 5.12 Cultura representacional en la revista Minusval (p.136)

Tabla 5.13 Cultura representacional intrínseca en la revista Minusval (p.137)

Tabla 5.14 Cultura representacional extrínseca en la revista Minusval (p.137)

Tabla 5.15 Cultura práctica en la revista Minusval (p.138)

Tabla 5.16 Cultura práctica intrínseca en la revista Minusval (p.139)

Tabla 5.17 Cultura práctica extrínseca en la revista Minusval (p.139)

Tabla 5.18 Cultura valorativa en la revista Minusval (p.140)

Tabla 5.19 Cultura valorativa intrínseca en la revista Minusval (p.141)

Tabla 5.20 Cultura valorativa extrínseca en la revista Minusval (p.141)

Tabla 5.21 Relación entre la cultura tecnológica extrínseca con la intrínseca en la Minusval (p.145) 
Tabla 5.22 Relación entre los contenidos prácticos y los valorativos (p. 146)

Tabla 5.23 Relación entre los contenidos prácticos y los representacionales (p.148)

Tabla 5.24 Relación entre los contenidos valorativos y los representacionales (p.149)

Tabla 6.1 Imágenes y valores positivos (p.155)

Tabla 6.2 Imágenes y valores negativos (p.170)

Tabla 6.3 Imágenes y valores deseados (p.177)

Tabla 6.4 Aparatos y técnicas (p.183)

Tabla 7.1 Fuentes de información científico-tecnológica de los ciudadanos (p.204)

Tabla 7.2 Estimación entre los textos periodísticos de cultura científica y el total de textos publicados entre 2002 y 2005 (p.212)

Tabla 7.3 Estimación entre los textos periodísticos de discapacidad y el total de textos de cultura científica publicados entre 2002 y 2005 (p.213)

Tabla 7.4 Cultura científica en la prensa (p.216)

Tabla 7.5 Cultura científica por periódico (p.218)

Tabla 7.6 Cultura tecnológica en la prensa (p.219)

Tabla 7.7 Cultura tecnológica por periódico (p.220)

Tabla 7.8 Cultura científico-tecnológica intrínseca (p.221)

Tabla 7.9 Cultura científico-tecnológica intrínseca por periódico (p.222)

Tabla 7.10 Cultura científico-tecnológica extrínseca (p.222)

Tabla 7.11 Cultura científico-tecnológica extrínseca por periódico (p.223)

Tabla 7.12 Imágenes y valores positivos en la prensa (p.229)

Tabla 7.13 Imágenes y valores positivos por periódico (p.230)

Tabla 7.14 Imágenes y valores negativos en la prensa (p.239)

Tabla 7.15 Imágenes y valores negativos por periódico (p.240)

Tabla 7.16 Imagen de las PCD y su presencia en las noticias (p.244)

Tabla 7.17 Imagen de las PcD y valores positivos de las tecnologías (p.246)

Tabla 7.18 Imagen de las PcD y valores negativos de las tecnologías (p.247) 


\section{FIGURAS}

Fig. 0.1 Esquema de la relación entre las PcD y la CyT (p. 19)

Fig. 2.1 Definición del campo de las Tecnologías de la Rehabilitación (p.58)

Fig. 2.2 Publicaciones referidas a discapacidad por fuentes consultadas (p.74)

Fig. 2.3 Evolución temporal de la producción (p.81)

Fig. 2.4 Tipo de producción (p.82)

Fig. 2.5 Producción científica por temas (p.86)

Fig. 2.6 Instituciones con presencia en las publicaciones (p.88)

Fig. 2.7 Producción científica por universidades (p.91)

Fig. 4.1 Fases del análisis de contenido (p.105)

Fig. 5.1 Ciencia y tecnología en la revista Minusval (p.121)

Fig. 5.2 Cultura científica intrínseca en la Minusval (p.123)

Fig. 5.3 Cultura científica extrínseca en la Minusval (p.126)

Fig. 5.4 Cultura tecnológica intrínseca en la Minusval (p.117)

Fig. 5.5 Cultura tecnológica extrínseca en la Minusval (p.130)

Fig. 5.6 Tipo de información transmitida en la Minusval (p.135)

Fig. 5.7 Relación entre los contenidos prácticos y los valorativos (p.146)

Fig. 5.8 Relación entre los contenidos prácticos y los representacionales (p. 148)

Fig. 5.9 Relación entre los contenidos valorativos y los representacionales (p.150)

Fig. 6.1 Imágenes y valores asociados a la tecnología (p.154)

Fig. 6.2 Grupo Informática en relación a imágenes y valores positivos (p.185)

Fig. 6.3 Resumen de Grupo Informática en relación a imágenes y valores positivos (p.186)

Fig. 6.4 Grupo Informática en relación a imágenes y valores negativos (p.187)

Fig. 6.5 Resumen de Grupo Informática en relación a imágenes y valores negativos (p.188)

Fig. 6.6 Grupo Informática en relación a imágenes y valores deseados (p.188)

Fig. 6.7 Resumen de Grupo Informática en relación a imágenes y valores deseados (p.189)

Fig. 6.8 Grupo Telefonía en relación a imágenes y valores positivos (p.190)

Fig. 6.9 Resumen de Grupo Telefonía en relación a imágenes y valores positivos (p.191)

Fig. 6.10 Grupo Telefonía en relación a imágenes y valores (p.192)

Fig. 6.11 Resumen de Grupo Telefonía en relación a imágenes y valores negativos (p.192)

Fig. 6.12 Grupo Telefonía en relación a imágenes y valores deseados (p.193)

Fig. 6.13 Resumen de Grupo Telefonía en relación a imágenes y valores deseados (p.193)

Fig. 6.14 Grupo Tecnologías Específicas en relación a imágenes y valores positivos (p.194)

Fig. 6.15 Resumen de Grupo Tecnologías Específicas en relación a imágenes y valores positivos (p.196)

Fig. 6.16 Grupo Tecnologías Específicas en relación a imágenes y valores negativos (p.197)

Fig. 6.17 Resumen de Grupo Tecnologías Específicas en relación a imágenes y valores negativos (p.198) 
Fig. 6.18 Grupo Tecnologías Específicas en relación a imágenes y valores deseados (p.199)

Fig. 6.19 Resumen de Grupo Tecnologías Específicas en relación a imágenes y valores deseados (p.200)

Fig. 7.1 Base de Datos Access (p.208)

Fig. 7.2 Ejemplo del análisis de las noticias con el programa informático de análisis de contenido ATLAS.ti (p.211)

Fig. 7.3 Evolución temporal por periódico (p.214)

Fig. 7.4 Presencia de la discapacidad en las noticias de ciencia y tecnología (p.215)

Fig. 7.5 Cultura científico-tecnológica en las noticias (p.216)

Fig. 7.6 Imagen de las PcD en las noticias en su relación con la tecnología (p.224)

Fig. 7.7 Imágenes y valores de la tecnología en su relación con las PcD en las noticias (p.228)

Fig. 9.1 Modelo de la Información Cultural Tecnológica (p.263) 
